$$
\text { UNIVERSIDADE DE SÃO PAULO }
$$

FACULDADE DE FILOSOFIA, LETRAS E CIÊNCIAS HUMANAS DEPARTAMENTO DE LETRAS CLÁSSICAS E VERNÁCULAS PROGRAMA DE PÓS-GRADUAÇÃO EM FILOLOGIA E LÍNGUA PORTUGUESA

\title{
HIPERTEXTUALIDADE: \\ UMA ABORDAGEM BAKHTINIANA SOBRE RELAÇÕES DIALÓGICAS ENTRE ENUNCIADOS EM REDE
}

Flávia Silvia Machado

São Paulo 


$$
\text { UNIVERSIDADE DE SÃO PAULO }
$$

FACULDADE DE FILOSOFIA, LETRAS E CIÊNCIAS HUMANAS

DEPARTAMENTO DE LETRAS CLÁSSICAS E VERNÁCULAS

PROGRAMA DE PÓS-GRADUAÇÃO EM FILOLOGIA E LÍNGUA PORTUGUESA

\section{HIPERTEXTUALIDADE: \\ UMA ABORDAGEM BAKHTINIANA SOBRE RELAÇÕES DIALÓGICAS ENTRE ENUNCIADOS EM REDE}

Flávia Silvia Machado

Tese apresentada ao Programa de Pós-Graduação em Filologia e Língua Portuguesa do Departamento de Letras Clássicas e Vernáculas da Faculdade de Filosofia, Letras e Ciências Humanas da Universidade de São Paulo, para obtenção do título de Doutora em Letras.

Orientadora: Profa. Dra. Sheila Vieira de Camargo Grillo

São Paulo

2012

Exemplar original 
Autorizo a reprodução e divulgação total ou parcial deste trabalho, por qualquer meio convencional ou eletrônico, para fins de estudo e pesquisa, desde que citada a fonte.

Catalogação na Publicação

Serviço de Biblioteca e Documentação

Faculdade de Filosofia, Letras e Ciências Humanas da Universidade de São Paulo

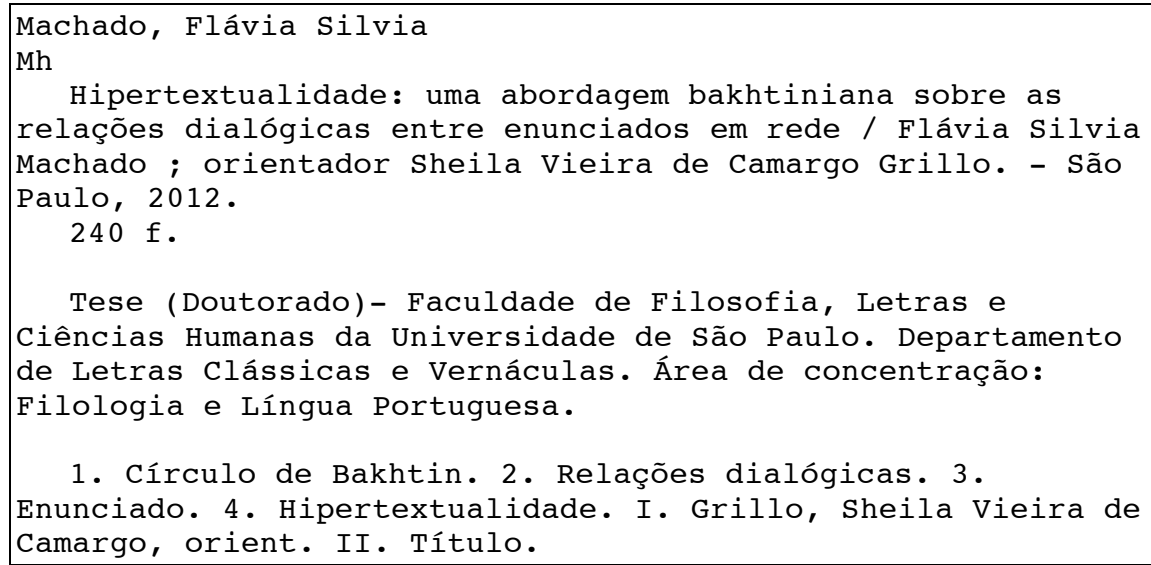


MACHADO, Flávia Silvia. Hipertextualidade: uma abordagem bakhtiniana sobre relações dialógicas entre enunciados em rede. Tese apresentada à Faculdade de Filosofia, Letras e Ciências Humanas da Universidade de São Paulo para obtenção do título de Doutora em Letras.

\section{BANCA EXAMINADORA}

Profa. Dra. Elisabeth Brait (USP/ PUC-SP)

Profa. Dra. Mercedes de Fátima Canha Crescitelli (PUC-SP)

Prof. Dr. Antonio Carlos Xavier (UFPE)

Profa. Dra. Zilda Gaspar Oliveira de Aquino (USP)

Profa. Dra. Maria Inês Batista Campos

Profa. Dra. Irene de Araújo Machado

Profa. Dra. Maria Lúcia da Cunha Victório 
Aos meus pais, Pedro e Carmem. 


\section{AGRADECIMENTOS}

minha orientadora, Profa. Dra. Sheila Vieira de Camargo Grillo, pela
competência e amor com que dirigiu a pesquisa. Foram 8 anos de
investimento na minha formação, ensinando e orientado para além da tese, mas para a própria vida;

Aos membros da banca de qualificação e defesa Profa. Dra. Beth Brait (USP/PUCSP), minha querida 'vó de orientação', Profa. Dra. Mercedes Fátima Canha Crescitelli (PUC$\mathrm{SP}$ ), cujas preciosas observações ajudaram-nos a determinar os rumos teórico-metodológicos da pesquisa;

Aos demais membros da banca de defesa, Prof. Dr. Antonio Carlos Xavier (UFPE) e Profa. Dra. Zilda Gaspar Oliveira de Aquino (USP) que, ao lado das professoras Beth e Mercedes, investiram tempo e carinho na leitura do meu trabalho. Certamente, todos os membros da banca são inspirações que levarei comigo em minha vida acadêmica;

À agência de fomento FAPESP que possibilitou com que eu me dedicasse integralmente à tese, financiando meus estudos e viagens nacionais e internacionais para a divulgação da pesquisa e à CAPES, responsável pelo financiamento dos meus estudos na Université Paris 3, durante o doutorado sanduíche em Paris;

À Mme Sophie Moirand, que me acolheu de forma gentil e abriu as portas do CEDISCOR. Foi por meio dela que conheci Isabella Lembi, parceira acadêmica e amiga querida. A estadia em Paris foi, certamente, uma experiência definitiva e transformadora no que tange à minha vida pessoal e à minha formação como pesquisadora. Participaram desse processo os integrantes mais queridos do terceiro andar da Maison du Brésil: Igor, Lígia, Gustavo, Mônica, Verônica, Paula, Ricardo, Astrid, Marta, Gilberto, Marnes, Guilherme Kaylyn e Fernanda;

À querida professora e colega Claudia Ozon, minha preparadora para provas de proficiência, conferências e a própria vida em Paris;

Aos meus irmãos de orientação, parceiros de pesquisa e amigos: Arlete, Inti, Arthur, Luiz Rosalvo, Michele e Ana Paula. Devo um agradecimento especial à Simone, minha querida veterana que carinhosamente revisou a tese e que esteve comigo desde o início dessa jornada. Além deles, incluo Paulo Segundo, Cleide Cunha, Marcos Pires, Eduardo Piris e 
Josy Teixeira, pessoas que de alguma forma marcaram positivamente minha vida no âmbito pessoal e acadêmico em diversos momentos;

Às comissões do I e do III EPED (Encontro de Pós-Graduandos em Estudos Discursivos), pela convivência e pelo trabalho competente;

Aos familiares queridos que não só entenderam as minhas ausências, como estiveram presentes quando eu precisei: minhas madrinhas Nancy e Érica, meus primos - os melhores que alguém poderia ter na vida - , minhas tias, minha irmã Débora e toda a família Silva, além dos tios Nel e Fátima - especialmente pelos almoços e impressora. Incluo também um agradecimento especial aos amados amigos Pri Moraes, André e Angélica e as meninas da Escola do Futuro;

Aos professores da minha infância e adolescência, Prof. Pereira e o Teacher Dagoba, cujas aulas me inspiraram a querer ser uma professora de língua materna e estrangeira;

À M. Kolenitenko, por ter me interrompido diversas vezes com a sua graça, fazendo com que a volta ao trabalho fosse a mais feliz possível;

Ao Khaled, desejando que sua presença seja duradora em minha vida;

À minha mãe, por ter me acordado às $5 \mathrm{~h}$ da manhã todos os dias para pegar o fretado até a USP; por ter sido sempre muito presente em todos os aspectos da minha vida e por me ensinar a ir sempre em frente com alegria e confiança. Ao meu pai, por ser o meu herói e por me fazer sorrir em qualquer situação da vida, por mais difícil que ela seja. Foram, certamente, os meus maiores companheiros durante toda a jornada que me levou até a obtenção desse título. 


\section{RESUMO}

Com base nos conceitos da obra de Bakhtin e seu Círculo, defendemos a tese de que a hipertextualidade pode ser considerada uma modalidade de relação dialógica entre enunciados colocados em rede, tanto em meio digital como impresso, por algum mecanismo de remissão. Considerando as coerções de cada meio e partindo do pressuposto de que a internet é capaz de abrigar um conjunto de esferas, selecionamos reportagens de divulgação científica da $F S P$ e da $F O$, no período de 2000 a 2008, para compor o corpus da pesquisa. O modelo teórico-metodológico adotado foi formulado a partir da proposta de análise Metalinguística apresentada por Bakhtin em Problemas da Poética de Dostoiévski (2010 [1963]), e desenvolveu-se por meio dos seguintes passos: primeiramente, uma contextualização sócio-histórica dos enunciados; em seguida, a descrição e análise dos elementos constitutivos do gênero reportagem - conteúdo temático, forma composicional e estilo - e, finalmente, a observação das características dos meios impresso e digital. A análise revelou não somente os efeitos semântico-axiológicos encontrados nas relações dialógicas hipertextuais entre os enunciados, mas também levou-nos a delimitar os planos e mecanismos de remissão em que tais relações ocorrem. Os nós remissivos, que podem ser de natureza verbal ou verbo-visual, auxiliam na formação de uma complexa rede dialógica hipertextual no interior de um enunciado e na sua relação com enunciados externos, favorecendo a criação de diferentes conteúdos temáticos em cada meio. Em relação ao gênero discursivo, pudemos compreender que a sua conclusibilidade também difere de acordo com as relações dialógicas estabelecidas no jornal impresso ou no jornal digital. Enquanto a FSP admite reportagens mais extensas formadas por enunciados fragmentados ou mesmo pelo conjunto de vários enunciados, seja em sua dimensão verbal ou verbo-visual, os enunciados veiculados na FO possuem caráter mais autônomo, não retomando as mesmas relações dialógicas hipertextuais do jornal impresso.

Palavras-chave: hipertextualidade, relações dialógicas, gênero reportagem, divulgação científica, nós remissivos. 


\begin{abstract}
Based on the concepts of Bakhtin and his Circle, we defend the thesis that hypertextuality is a kind of dialogic relation between utterances, both in digital and printed media. Considering the constraints of each media and assuming that the Internet holds a set of spheres that are overlapped by the digital sphere, we have selected reports of scientific divulgation of Folha de S. Paulo and Folha Online in the period between 2000 to 2008, to compose the corpus of the research. The theoretical and methodological model adopted was inspired by the metalinguistic analysis formulated by Bakhtin, considering the following steps: first, a deep socio-historical contextualization of the utterances, the description and analysis of the constitutive elements of the genres - thematic content, compositional form and style - and the observation of the characteristics of each media. The analysis revealed not only the axiological-semantic effects found in the dialogical hypertextual relations between utterances, but also led us to refine the plans and mechanisms of remission in which such relations occur. The remissive nodes, which may be verbal or verbovisual, assist in the formation of a dialogical hypertextual complex within an utterance and its relationship with external utterances, favoring the creation of different thematic content in each media. Regarding the genre, we understand that its conclusibility also differs according to the dialogical relations established in printed or online newspaper. While FSP allows more extensive reports consisted of fragmented utterances or even a whole set of statements, either verbal or verbovisual, the statements conveyed in FO are more autonomous, not generating the same dialogical hypertextual relations.
\end{abstract}

Keywords: hypertextuality, dialogical relations, reportage, scientific divulgation, and remissive nodes. 


\section{RÉSUMÉ}

A partir des concepts de l'œuvre de Bakhtine et son Cercle on présente une thèse fondée sur l'hypertextualité comme une modalité de relation dialogique entre les énonces, y compris la version numérique ou imprimée. Le choix des reportages dans la période de 2000 à 2008 de vulgarisation scientifique de la Folha de S. Paulo et la Folha Online a été fait afin de constituer le corpus de la recherche en tenant compte des coercitions de chaque moyen et en supposant que l'Internet est constitué d'un jeu de sphères sur lequel se superpose le domaine numérique. Le modèle théorique et méthodologique choisi a été organisé suivant les pas de l'analyse métalinguistique formulée par Bakhtine et comprend les étapes suivantes: analyse profonde du contexte socio-historique des énoncés, description et de l'examen des éléments constitutifs du genre - le contenu thématique, la forme compositionnelle et le style - et observation des caractéristiques de chaque moyen. L'analyse a révélé non seulement quels sont les effets axiologique-sémantiques présents dans les relations dialogiques hypertextuelles entre les énoncés, mais a aussi conduit à circonscrire les plans et mécanismes de rémission dans lequel ces relations se produisent. Les liens de référence provenant de la dimension verbale ou verbovisuelle aident à la formation d'un complexe hypertextuelle dialogique au sein d'un énoncé et dans sa relation avec les énoncés externes en favorisant la création d'un contenu thématique différent dans chaque journal. Concernant le genre discursif on constate que leur conclusibilité diffère dans les relations dialogiques établies sur le journal imprimé ou sur le journal en ligne. Alors que Folha de S. Paulo admet des reportages plus extensifs constitués d'énoncés fragmentés ou même d'un ensemble de plusieurs énoncés, dans sa dimension verbal ou verbovisuelle, ceux qui sont véhiculés à Folha Online ont une plus grande autonomie et ne reprennent presque jamais les mêmes relations dialogiques hypertextuelles.

Mots-clés: hypertextualité, relations dialogiques, reportage, vulgarisation scientifique, liens de référence. 


\section{LISTA DE SIGLAS E ABREVIATURAS}

$\begin{array}{ll}\text { AD } & \text { Análise do discurso } \\ \text { BID } & \text { Banco Interamericano de Desenvolvimento } \\ \text { DC } & \text { Divulgação científica } \\ \text { FHC } & \text { Fernando Henrique Cardoso } \\ \text { FO } & \text { Folha Online } \\ \text { FSP } & \text { Folha de S. Paulo } \\ \text { LT } & \text { Linguística textual } \\ \text { MFL } & \text { Marxismo e Filosofia da Linguagem } \\ \text { OESP } & \text { O Estado de S. Paulo } \\ \text { ONU } & \text { Organização das Nações Unidas } \\ \text { PPD } & \text { Problemas da Poética de Dostoiévski }\end{array}$




\section{SUMÁRIO}

\section{INTRODUÇÃOO}

1.1 As relações entre textos, enunciados e discursos:

1.1.1 Da teoria literária: a formulação do conceito de intertextualidade e alguns desdobramentos

1.1.1.1 A análise de Julia Kristeva e a elaboração da intertextualidade 11

1.1.1.2 A transtextualidade de Genette 15

1.1.2 A intertextualidade sob o enfoque da Linguística Textual 20

1.1.3 Contribuições da AD francesa: interdiscursividade e heterogeneidade 23

1.2 As abordagens teóricas no âmbito dos estudos sobre o hipertexto 30

1.2.1 O estado da arte das concepções sobre hipertexto 31

1.2.2 A intertextualidade e a hipertextualidade no hipertexto 35

1.3 Hipertextualidade e relações dialógicas 38

1.3.1 A hipertextualidade e o gênero reportagem de divulgação científica impresso e digital

CAPÍTULO 2. O impresso e o digital: um estudo sobre meio, suporte e esfera

2.1 O meio como extensão do homem segundo Marshall McLuhan 46

2.2 A midiologia proposta por Régis Debray 53

2.3 Algumas considerações sobre o desenvolvimento do impresso 60

2.4 A virtualização e o ciberespaço $\quad 62$

2.5 A internet como conjunto de esferas da atividade humana 65

CAPÍTULO 3. O gênero reportagem de divulgação científica em foco: proposta para uma análise dialógica da hipertextualidade $\quad 72$

3.1 Seleção do corpus: a constituição do gênero reportagem de divulgação científica impresso e digital 
3.2 Aspectos fundamentais para a elaboração de uma análise dialógica: coerções e elementos constitutivos do gênero discursivo $\quad 86$

3.2.1 Forma composicional, hiperestrutura e hipertexto 87

3.2.2 Dimensão verbo-visual do enunciado 97

3.2.3 Estilo, projetos editorias e Manual da Redação do Grupo Folha 99

$\begin{array}{ll}\text { 3.2.4 Conteúdo temático } & 102\end{array}$

3.3 Um enunciado e diversas esferas: a formação da cultura científica na FSP na primeira década dos anos $2000 \quad 104$

3.4 Entrelaçando os fios teórico-metodológicos 108

Capítulo 4. Relações dialógicas hipertextuais em reportagens de DC de 2000 a 2005: o entrecruzamento dos discursos científico e político 111

4.1 Reportagens do ano 2000: a política impregnada nas tramas de um discurso sobre o meio ambiente

4.1.1 Uma abordagem metalinguística sobre o enunciado-fonte

4.1.2 A geração de temas a partir da relação hipertextual entre enunciados: da valorização da floresta ao descaso marcado na fala do presidente

4.1.3 A hipertextualidade na dimensão verbo-visual dos enunciados impressos

4.2 'Racha na economia' nacional e a ascensão americana na guerra contra o terror: implicações para os avanços científicos no ano de 2003

4.2.1 Aspectos estitístico-composicionais do corpus

4.2.2 A política científica e as duas faces da corrida espacial brasileira

4.2.3 A apropriação da esfera científica na dimensão verbo-visual

4.2.4 Síntese

4.3 Um reflexo sobre o interesse da sociedade acerca do meio ambiente e da corrida espacial: análise de reportagens do ano 2005

4.3.1 Confluências entre os enunciados impresso e digital

4.3.2 O clima político e o clima ambiental

4.3.3 Indícios de expansão da cultura científica 
Capítulo 5. A hipertextualidade e a consolidação da cultura científica na FSP e na FO

5.1 Retratos do homem pré-histórico e o ocultamento das questões políticas nacionais em reportagens do ano 2006

5.1.1 Uma nova dimensão espacial no jornal impresso 172

5.1.2 A hipertextualidade reconfigurada na dimensão verbo-visual 178

5.1.3 Relações dialógicas hipertextuais e os nós remissivos na FSP e na FO 186

5.1.4 Síntese

5.2 A soberania da esfera científica sobre a política em 2007

5.2.1 Esquemas explicativos e infográficos: o enriquecimento do discurso de DC 190

5.2.2 Planos de remissão e relações dialógicas hipertextuais: uma estratégia de posicionamento ideológico

5.2.3 Síntese

5.3 Reportagens do ano 2008: a curiosidade versus a cientificidade

5.3.1 A maior autonomia dos infográficos: novos parâmetros para a conclusibilidade temática e composicional do enunciado verbo-visual na FSP

5.3.2 Um novo tipo de remissão hipertextual na FO 


\section{INTRODUÇÃO}

O papel tem mais paciência do que as pessoas.

(O diário de Anne Frank, 1942-44)

$\mathrm{E}$

m março de 2010, a ONU (Organização das Nações Unidas), juntamente com o Centro Anne Frank nos Estados Unidos, lançou uma campanha sobre a conscientização em torno do Holocausto ${ }^{1}$ em memória da garota judia morta pelo regime nazista. O objetivo específico da campanha era "encorajar os jovens a aprender por meio de sua experiência ao se esconder dos nazistas nos meses finais de sua vida ${ }^{2}$. A dinâmica pedia para que usuários da rede mundial de diversas partes do mundo deixassem mensagens para Anne Frank em uma conta do Twitter ${ }^{3}$, imaginando que a garota pudesse acessá-las secretamente naquela época. Tal exercício de conscientização proposto pela ONU não obteve a adesão esperada, talvez por conta da disparidade contextual do público alvo em relação às questões sócio-históricas envolvendo a vida de Anne Frank.

Realmente não é convencional associar o relato de sobrevivência e guerra da garota judia às possibilidades geradas pela comunicação em meio digital. Se a autora tivesse registrado tudo em um blog, por exemplo, o cenário seria muito diferente. Seus escritos teriam sido instantaneamente acessados por seus seguidores, o conteúdo seria registrado e compartilhado, e a responsividade gerada em torno de suas publicações seria imediata, ou seja, a interatividade proporcionaria outras qualidades ao diário de Anne Frank. Não somente a história de Anne Frank teria sido diferente, mas a própria guerra e seus desdobramentos teriam tomado outros rumos.

Os aspectos sócio-históricos e também tecnológicos de uma época fazem dos enunciados acontecimentos únicos e irrepetíveis, tal como postula Bakhtin e os pensadores de seu Círculo. A tecnologia e os meios de veiculação da linguagem viva são fatores intrínsecos

\footnotetext{
${ }^{1}$ Disponível em: http://www.un.org/News/Press/docs/2010/note6253.doc.htm, acessado em 20/05/2012.

${ }^{2}$ Tradução livre do original: "with the aim of encouraging young people to learn from her experience hiding from the Nazis in the final months of her life".

${ }^{3}$ Rede social de microblogging que permite que usuários postem atualizações sobre assuntos variados em até 140 caracteres.
} 
à concretização dos enunciados ao longo do tempo. A iniciativa da ONU poderia ter atingido mais jovens se, porventura, houvesse uma adaptação de trechos do Diário em um blog, mas mesmo assim os enunciados transpostos da obra impressa transformar-se-iam em novos enunciados no meio digital. Se compararmos um diário pessoal escrito na época e um blog de relatos também pessoais publicado na rede mundial de computadores atualmente, perceberemos que o leitor presumido onipresente no segundo caso interfere no processo de produção do enunciado. O diário escrito, cujo suporte poderia vir acompanhado por uma chave para garantir a confidencialidade do conteúdo, constituía-se em uma reflexão individual e mais monológica, enquanto o blog de relato pessoal é mais responsivo por conta da interatividade com o leitor presumido, fato propiciado tanto pela seção de comentários sempre disposta ao final de cada postagem, permitindo a inserção de outros enunciados pelos leitores, quanto pela própria acessibilidade 24 horas que caracteriza a internet.

Anne Frank tem razão quando afirma que o papel, enquanto suporte que recebe os enunciados manuscritos de seu diário, tem mais paciência do que as pessoas nesse caso, pois naquele momento não há recepção imediata sobre o que ela escreve. Aliás, a preservação dos seus escritos equivalia à preservação da própria vida em um regime ditatorial nazista. Se a sua época fosse movida pela internet, certamente a vida de Anne Frank e toda a configuração mundial seriam outras. Sua relação com o papel não passava pelo crivo da interatividade com outros falantes, mesmo não deixando de constituir-se dialogicamente como uma resposta aos seus opressores e a seus próprios anseios. Talvez somente o papel pudesse preservar os escritos da jovem autora para a posteridade naquele momento.

A partir dessa reflexão, destacamos dois pontos importantes para a introdução de nossa tese: primeiramente, cada tecnologia e suporte exercem uma influência sobre os enunciados que veiculam e, em segundo lugar, cada nova tecnologia apropria-se de características de outros meios a fim de criar parâmetros próprios, sobretudo nos seus processos enunciativos. O hipertexto é um exemplo de como a tecnologia digital incorporou um aspecto presente anteriormente em documentos impressos. Nesse caso, o que antes parecia ser mais uma forma de organizar compilações de textos impressos - como em índices - , possibilitar a adição ou explicação complementar ao texto - tal como as notas de rodapé em uma tese - ou mesmo uma maneira não linear de relacionar enunciados ou fragmentos dele, como encontramos na forma composicional - adotada por Júlio Cortázar no romance Jogo de Amarelinha - atualmente tornou-se uma das características mais produtivas dos enunciados digitais. 
Consequentemente, a potencialização do uso do hipertexto em meio digital influenciou o jornal impresso, por exemplo, que passou a compor suas reportagens de forma hipertextual, como apresentamos ao longo da tese. Os hipertextos passaram a ser configurados em meio impresso, fragmentando as reportagens e compondo certas unidades temáticas e estilísticocomposicionais dos enunciados, enquanto o meio digital potencializou seu uso por meio da inserção do nó eletrônico. O impacto também abrangeu as relações dialógicas formadas a partir do enunciado-fonte em meio impresso e digital, a partir do que denominamos hipertextualidade.

Com base em tal constatação, propomos uma tese de fundamentação bakhtiniana em que a hipertextualidade é considerada uma modalidade de relação dialógica que coloca enunciados interligados em rede por algum mecanismo de remissão em um mesmo plano de sentido. A hipótese que motivou a tese emergiu dos resultados da dissertação de mestrado anterior (Machado, 2007) que visou ao exame das relações dialógicas remissivas entre enunciados em meio digital. Partimos da observação da articulação entre enunciados por meio dos nós eletrônicos e passamos a considerar que as relações dialógicas estabelecidas nesse contexto possuíam especificidades que se diferenciavam de outros tipos de relação dialógica, como o discurso citado direto ou indireto, que visavam à incorporação de fragmentos de um enunciado em outro. Ao contrário, as relações dialógicas que denominamos hipertextuais baseiam-se em nós remissivos que apontam para o exterior do enunciado em planos distintos, a saber: entre enunciados de uma mesma reportagem e entre enunciados de reportagens ou mesmo páginas distintas.

Com base na pesquisa anterior sobre as relações dialógicas hipertextuais, nosso intuito é o de formular a definição de hipertextualidade a partir da análise do gênero reportagem de divulgação científica (doravante DC) em meio impresso e digital, levando em consideração as esferas de onde emergem os enunciados que compõem o corpus. Portanto, a pergunta de pesquisa que direcionou a tese é a seguinte:

Enquanto uma modalidade de relação dialógica, como se configura a hipertextualidade em enunciados de divulgação científica colocados em rede por algum mecanismo de remissão nos meios impresso e digital?

A fim de responder a tal questão, optamos por desenvolver duas frentes de reflexão que mobilizassem domínios teóricos específicos para, primeiramente, definir a hipertextualidade como uma modalidade dialógica e, segundo, para estabelecer as relações de influência entre 
os meios impresso e digital, bem como a noção de internet com que iremos trabalhar. Logo, a primeira etapa da fundamentação teórica voltou-se para os conceitos da teoria do Círculo de Bakhtin e alguns desdobramentos diretos ou indiretos da teoria dialógica proposta em outros domínios teóricos, tal como as noções de intertextualidade segundo Julia Kristeva e a tipologia de transtextualidade de acordo com Gérard Genette no âmbito da Teoria Literária; a análise de autores da Linguística Textual; e também as contribuições de autores da AD francesa, tal como as noções de interdiscursividade em Pechêux e a heterogeneidade formulada por Authier-Revuz.

A segunda frente teórica procurou dar conta de aspectos relacionados à definição de internet e à relação entre os meios impresso e digital. Para isso, consideramos as definições de meio, suporte e mídium dos pesquisadores Marshall McLuhan, Régis Debray e Roger Chartier. Para a definição da internet como um conjunto de esferas da atividade humana, tal como nos apresenta a teoria do Círculo de Bakhtin, também contamos com a perspectiva teórica sobre o ciberespaço do filósofo Pierre Lévy.

Uma vez estabelecidos os fundamentos teóricos da pesquisa, elaboramos o modelo teórico-metodológico para a posterior análise dos enunciados. O corpus é composto por enunciados do gênero reportagem de DC tanto da versão impressa quanto da versão digital de um jornal de grande circulação no estado de São Paulo. As reportagens, que compreendem o período entre 2000 e 2008, foram retiradas do jornal impresso A Folha de $S$. Paulo (doravante FSP) e do jornal digital Folha Online (FO), ambas publicações do Grupo Folha.

O modelo de análise adotado foi formulado a partir das análises e conceitos desenvolvidos por Bakhtin e seu Círculo, seguindo as seguintes diretrizes: a contextualização sócio-histórica dos enunciados; a descrição e observação dos elementos constitutivos do gênero reportagem de divulgação científica (DC); e o exame das coerções de cada meio sobre o processo de produção, circulação e recepção das reportagens.

A análise foi dividida em dois momentos, de acordo com a significativa modificação de ordem estilístico-composicional do ano de 2006, coincidindo com os avanços do processo de estabelecimento da cultura científica no país, bem como com a maior difusão da rede mundial de computadores entre usuários brasileiros. Iniciamos a análise com a contextualização promovida pelos próprios jornais que veicularam as reportagens, devido ao seu caráter que denominamos autocontextualizador.

$\mathrm{O}$ próximo passo foi analisar os elementos relacionados ao estilo e à forma composicional e suas categorias de análise: a hiperestrutura; o hipertexto e os nós 
remissivos; e a dimensão verbo-visual dos enunciados. Por fim, apreendemos o conteúdo temático resultante dos enunciados e da relação entre eles. Com isso, pudemos depreender os diferentes planos de relação dialógica hipertextual e que tipos de nós remissivos de ordem verbal e extraverbal propiciam tais relações, para, finalmente, destacar a hipertextualidade tanto em meio impresso como digital.

A elaboração da tese é justificada, primeiramente, pois apresenta uma contribuição dos estudos bakhtinianos ao elaborar a noção de hipertextualidade como uma modalidade de relação dialógica do enunciado. Além disso, não operamos somente com a ocorrência do hipertexto em textos digitais, mas procuramos analisar a ocorrência do hipertexto em enunciados impressos e por meio de nós remissivos variados. Outro fator que destacamos é a reflexão que trazemos sobre os seguintes aspectos fundamentais da tese: a definição da internet como um conglomerado de esferas da atividade humana sobre o qual se sobrepõe a esfera digital; o meio interferindo na conclusibilidade de enunciados do gênero reportagem impressa e digital e a proposta de um modelo teórico-metodológico ancorado na disciplina Metalinguística bakhtiniana.

Com base nas próprias justificativas, os objetivos específicos estabelecidos para o desenvolvimento da atual tese são: (i) apresentar uma proposta teórica de abordagem bakhtiniana sobre a hipertextualidade como um tipo de relação dialógica; (ii) analisar as relações dialógicas hipertextuais estabelecidas no gênero reportagem de DC e identificar os tipos de nós remissivos em cada caso; e (iii) descrever e compreender os sentidos acarretados pelas relações dialógicas hipertextuais.

A tese que apresentamos está organizada em cinco capítulos. O primeiro refere-se à fundamentação teórica em torno do conceito de hipertextualidade, bem como do estudo de outras teorias que privilegiam a relação entre textos e discursos. Percorremos teorias da Literatura, da Análise do Discurso francesa e da Linguística Textual para compreender conceitos como intertextualidade, transtextualidade, interdiscursividade e heterogeneidade. No entanto, o conceito-chave a partir do qual se desdobra nossa definição de hipertextualidade é o de relação dialógica, tal como formulado pela teoria do Círculo de Bakhtin. O segundo capítulo é dedicado às definições acerca de meio e suporte a partir das teorias formuladas por McLuhan (2007), Debray (1991, 1993, 1994 e 2000), Chartier (2001 e 2009) e Lévy (1993, 1996 e 1999), bem como da noção de esfera da atividade humana, momento em que projetamos um olhar teórico bakhtiniano sobre a internet. O terceiro capítulo apresenta um modelo teórico-metodológico metalinguístico inspirado nas análises de Bakhtin sobre a obra de Dostoiévski, contemplando os elementos linguísticos e 
extralinguísticos que constituem os enunciados. Finalmente, partimos para a análise das reportagens selecionadas entre os anos de 2000 e 2008, dividida em dois capítulos. O capítulo 4 analisa os enunciados de 2000 a 2005, enquanto o capítulo 5 privilegia os enunciados dos anos seguintes, 2006 a 2008. 


\section{CAPÍTULO 1.}

A CONSTITUIÇÃO DAS RELAÇÕES DIALÓGICAS HIPERTEXTUAIS

Durante a década de 1920, a discussão central nas obras do Círculo de Bakhtin voltava-se à crítica ao Método Formal, imperativo no cenário intelectual russo da época. Os pensadores do Círculo concebiam um novo olhar ao objeto estético: uma análise que considerasse o entorno sócio-histórico da arte e os aspectos para além de sua materialidade. Em O problema do conteúdo, do material e da forma na criação verbal (1975[1923-24]), Bakhtin problematiza a primazia do material nos estudos da Estética, propondo um olhar sobre como os valores físicos e morais do homem e da natureza são organizados e concretizados na materialidade. O texto atribuído a Volóchinov, Discurso na vida e discurso na arte (1981[1926]), reforça a crítica aos formalistas, a partir da proposta de uma perspectiva sociológica aplicada à análise artística que não se restringe ao objeto estético como um artefato, mas o toma em toda a sua dimensão social. Podemos citar ainda, a obra The Formal Method ([1928]), em que Medviédev tece uma longa crítica ao método, ressaltando que os formalistas preocupavam-se com questões de ordem estritamente composicional da obra estética, não levando em conta, por exemplo, a dimensão de seus aspectos temáticos.

De forma sucinta, percebemos que o contraponto com o Método Formal foi uma das forças impulsionadoras do desenvolvimento da teoria bakhtiniana em sua fase inicial. Ao lidarmos com uma abordagem metalinguística, em concepção bakhtiniana, faz-se mister remontarmos aos textos fundadores dessa teoria, cuja metodologia deve ser compreendida pela totalidade das obras. Quase um século mais tarde, a presente tese visa empregar os conceitos formulados no âmbito da teoria do Círculo de Bakhtin para compreender os sentidos gerados pelas relações dialógicas hipertextuais no discurso de divulgação científica em meio impresso e digital - este último gerado por uma tecnologia desconhecida à época do fundador da teoria metalinguística. 
A ponte entre os preceitos da teoria bakhtiniana, compreendida no início na década de 1920 e em sua consolidação com os textos finais de Mikhail Bakhtin até os anos 1960, e a noção de hipertextualidade proposta em nossa tese será dada a exemplo do que os pensadores do Círculo exerciam naquele momento: o diálogo com outras perspectivas teóricas. Sendo o nosso objetivo analisar relações dialógicas entre enunciados, interessa-nos estudar como outras teorias apreenderam a noção de relações dialógicas e quais suas propostas para compreender as relações entre suas respectivas unidades de sentido: o texto, o enunciado ou o discurso.

Dois fatores centrais culminaram na escolha de tal percurso teórico: em primeiro lugar, nossa proposta acerca da noção de hipertextualidade surge na contraposição com perspectivas que associam os sentidos gerados na relação remissiva entre enunciados à intertextualidade. Observando o quão produtivo é o conceito de intertextualidade para caracterizar relações dialógicas no hipertexto em estudos brasileiros da última década, não seria pertinente situarmos a hipertextualidade na teoria bakhtiniana, sem antes refletirmos sobre tal formulação.

A relação entre intertextualidade e hipertexto no quadro teórico brasileiro resulta do interesse pioneiro de estudiosos da Linguística Textual (LT) no Brasil, cujas pesquisas são fundadoras para os pesquisadores da área. Sendo a intertextualidade uma de suas principais unidades de análise, é sob este prisma que a LT delineia suas propostas teóricas sobre o hipertexto. Portanto, contemplar a intertextualidade, não somente como uma categoria mobilizada pela LT, mas também como teorização cunhada a partir da crítica literária por meio dos olhares de Julia Kristeva e Gerard Genette, serve como a ponta do fio condutor que nos levará a uma análise metalinguística sobre o hipertexto em que a hipertextualidade configura-se como uma modalidade de relação dialógica entre enunciados colocados em rede por algum tipo de mecanismo de remissão.

Em segundo lugar, consideramos essencial incorporar os conceitos de interdiscursividade e heterogeneidade que, além de auxiliar-nos a situar a noção de hipertextualidade em um quadro epistemologicamente complexo, também tem servido de base para estudos sobre o hipertexto no Brasil e no cenário internacional. Dessa forma, o capítulo inicial da tese delineia-se pela pluralidade de teorizações sobre as relações de sentido no plano literário, enunciativo e discursivo, preservando como cerne a noção de dialogismo de concepção bakhtiniana. 


\subsection{As relações entre textos, enunciados e discursos}

Neste primeiro capítulo, especificamos o conceito de hipertextualidade como uma modalidade dialógica que coloca enunciados em relações de sentido, dispostos em rede por meio de algum mecanismo de remissão. A hipótese geradora da pesquisa surgiu da observação (Machado, 2007) de que o tipo de relação dialógica estabelecida pelo dispositivo remissivo que articula enunciados em um hipertexto, sendo ele digital ou não, pertence a uma ordem específica e diferenciada. Ao contrário do tipo de relação dialógica presente no discurso citado - em que há a inserção mais ou menos explícita da voz do outro num enunciado dado, pelo uso de aspas -, de discurso citado indireto ou indireto livre, a hipertextualidade ocorre por meio de um movimento contrário que aponta para um objeto discursivo que está fora do enunciado em questão. Logo, o que particulariza tal tipo de relação dialógica é o fato de que os sentidos estão estabelecidos pela própria dinâmica de remissão entre os enunciados do hipertexto.

Motivado pelos conceitos formulados pelos pensadores russos do Círculo de Bakhtin a partir da década 1920, o primeiro capítulo da tese estrutura-se em três partes. A primeira delas corresponde a uma reflexão sobre teorias da linguagem e da literatura que tratam da relação de sentido estabelecida entres textos, enunciados ou discursos, de acordo com as noções mobilizadas por cada uma delas. A compreensão das definições do que consideramos como relações dialógicas sob diferentes pontos-de-vista teóricos e as aproximações e divergências conceituais entre eles certamente contribui para a nossa formulação da noção de hipertextualidade, sobretudo quando certa teoria refere-se diretamente à noção bakhtiniana de relação dialógica.

Da teoria literária, citamos a intertextualidade de Julia Kristeva que, por sua vez, embasa a tipologia de transtextualidade de Gérard Genette. Observamos que a tipologia de Genette é produtiva para os estudos sobre hipertexto e hipertextualidade de alguns autores. Já a Linguística Textual apoia-se tanto na teorização de Kristeva, quanto na de Bakhtin, para definir o texto e as relações implícitas ou explícitas entre eles. Além da intertextualidade, outras concepções importantes propõem a relação de sentido a partir do confronto de enunciados. Na proposta de Authier-Revuz, busca-se a presença e a voz do Outro por meio da heterogeneidade mostrada, marcada ou não no texto, e da heterogeneidade constitutiva nas formas da linguagem. Destacamos, ainda, a interdiscursividade no âmbito da Análise do Discurso (AD) francesa que também recupera o conceito de dialogismo bakhtiniano como base ao tratar da relação entre as formações discursivas. 
A seção seguinte busca discorrer sobre o atual estado da arte no âmbito dos estudos sobre hipertexto. A multiplicidade de definições sobre hipertexto e hipertextualidade, conceitos passíveis de exaustivas redefinições, foi um dos fatores motivadores da nossa discussão. Por um lado, há autores que julgam o hipertexto um tipo de paratexto e empregam a paratextualidade postulada pela tipologia de Gérard Genette. Por outro, há aqueles que diferem hipertexto e hipertextualidade, ou, ao contrário, os definem como um conceito único.

Outro aspecto relevante é a relação entre intertextualidade e hipertextualidade, que sofrem variações segundo o posicionamento teórico de alguns autores. Proveniente da multiplicidade de definições apontadas pelo aspecto anterior, verificamos que, para alguns, as remissões hipertextuais são consideradas relações intertextuais. Por exemplo, ao discorrer sobre a interatividade propiciada pela internet, Komesu (2004) afirma que "o suporte oferece dispositivos para o vínculo entre os textos em rede. A intertextualidade torna-se, pois, explícita no mecanismo dos links das páginas hipertextuais.” (p.118). Ao lado de outros pesquisadores, Garcia (2005) também estabelece uma relação entre intertextualidade e hipertextualidade que será descrita posteriormente. No que tange à hipertextualidade, não foram encontradas propostas que a considerem uma modalidade dialógica da linguagem. No entanto, deparamo-nos com pesquisas que a caracterizam como um processo enunciativo, a saber, Xavier (2002) e Lobo (2009).

A terceira parte de nossa reflexão estabelece uma nova diretriz em meio aos estudos sobre as relações de sentido que constituem o hipertexto. Nossa proposta considera a hipertextualidade como um tipo relação dialógica entre enunciados que, explicitamente marcado por um nó, como no caso do link eletrônico, ou menos aparente como em uma conjuntura hiperestrutural da página do jornal impresso, emerge de um mecanismo de remissão de um enunciado-fonte A a um enunciado-derivado B. Com base na tese que apresentamos inicialmente neste capítulo, pretendemos mostrar que as relações dialógicas hipertextuais são constitutivas de enunciados do gênero reportagem de divulgação científica tanto em meio impresso quanto em meio digital.

\subsubsection{Da teoria literária: a formulação do conceito de intertextualidade e alguns desdobramentos}

Nossa reflexão parte da noção de intertextualidade formulada no âmbito dos estudos estruturalistas da linguagem e da literatura, surgidos nos anos 1950. Dominante nos estudos em Ciências Humanas na segunda metade do século XX, o movimento estruturalista no 
mundo foi influenciado pela era formalista russa, contudo, sem constituir-se como uma oposição ou uma continuação a essa conjuntura teórica (Santos, 2009, p. 126). Dentre as formulações mais relevantes sobre o conceito de intertextualidade que emergiu dos estudos literários, podemos citar a obra de Michel Riffaterre (1983). O autor considera a intertextualidade como uma construção do leitor a partir do conjunto de obras que precederam a leitura daquela. Outra importante referência é o número 27 da Revista Poétique, organizada por Laurent Jenny dedicada à intertextualidade.

\subsubsection{A análise de Julia Kristeva e a elaboração da intertextualidade}

$\mathrm{Na}$ década de 1960, em que Kristeva formulara a intertextualidade como um desdobramento da teoria bakhtiniana, as obras do Círculo ainda eram pouco difundidas. A noção de intertextualidade foi apreendida do conceito de dialogismo pela esfera acadêmica francesa antes mesmo dos demais conceitos bakhtinianos serem mais profundamente conhecidos. A pesquisadora búlgara foi responsável pela introdução do termo "intertextualidade" no cenário dos estudos literários. Seu interesse maior era o de compreender o mecanismo de relação entre textos e gêneros da esfera literária, com especial atenção aos romances.

Foi Kristeva quem escreveu a apresentação da obra La poétique de Dostoiéviski, traduzida do russo por Isabelle Kolitcheff em 1970, intitulada Une poétique ruinée. Em seu texto, a autora revisita a poética russa em meio à análise de Bakhtin que considerava a historicidade da obra como um aspecto fundamental para a apreensão do sentido da obra artística. Segundo a autora, “o objetivo de sua análise não é somente esclarecer como uma obra é feita, mas também situá-la no interior de uma tipologia de sistemas significantes na história" (p.11) ${ }^{4}$. Kristeva ainda ressalta a crítica aos formalistas russos feita por Volóchinov e Medviédev ${ }^{5}$ a partir da elaboração de uma teoria literária de caráter marxista.

Em Le mot, le dialogue et le roman (1969 [1966] $]^{6}$ ), a autora revela sua afinidade com a crítica bakhtiniana aos formalistas russos, apontando que sua análise não contemplava

\footnotetext{
4 “Le but de son analyse n'est plus d'élucider comment est faire une ouvre, mais de la situer à l'intérieur d'une typologie des systèmes signifiants dans l'histoire”. (Kristeva, 1970, p. 11).

${ }^{5} \mathrm{O}$ acento gráfico é utilizado para assinalar a sílaba tônica presente nos sobrenomes dos autores citados.

${ }^{6}$ Texto originalmente escrito em 1966 e publicado em 1967 na revista francesa Critique. "Bakhtine, le mot, le dialogue et le roman," Critique, XXIII, 239, April 1967, p. 438-65.
} 
questões "extra-literárias" (p.82-83). Por meio da leitura das obras Problèmes de la poétique de Dostoïevski (1963) e L'Oeuvre de François Rabelais (1965), Kristeva cita, ainda, a "profética" análise de Bakhtin como um evento marcante na tentativa de exceder a esta poderosa escola ao abordar os problemas fundamentais que afrontavam os estudos estruturalistas da época. Em oposição ao pensamento formalista russo vigente e à luz da então pouco conhecida teoria metalinguística de Bakhtin, Kristeva propõe um modelo de texto romanesco constituído pelo cruzamento entre vários outros textos.

\begin{abstract}
Bakhtin é um dos primeiros a substituir o caráter estático dos textos por um modelo onde a estrutura literária (...) se elabora comparada a outra estrutura. Essa dinamização do estruturalismo só é possível a partir de uma concepção, segundo a qual a palavra literária não é um ponto fixo (um sentido fixo), mas um cruzamento de superfícies textuais, um diálogo de muitos escritos. ${ }^{7}$ (idem, p. 83)
\end{abstract}

Faz-se importante notar que Kristeva tece a ressalva sobre a crítica bakhtiniana ao formalismo russo e incorpora a ideia de historicidade e exterioridade em sua teorização sobre os textos romanescos, discorrendo a partir de um posicionamento estruturalista constitutivo de sua época ${ }^{8}$. Para a autora, o texto como unidade de análise transcende à materialidade da língua sendo duplamente orientado: pelo sistema de significação em que é produzido e pelo processo social que participa no discurso. Trata-se de uma produtividade, cuja relação com a língua em que está situado é redistributiva. Isto é, há "uma permutação de textos, uma intertextualidade; no espaço de um texto, vários enunciados se cruzam e se neutralizam" (Kristeva, 1969 [1966-1967], p.52).

Em sua clássica definição, Kristeva afirma que todo texto é um mosaico de citações constituído por uma sucessão de textos já escritos ou que ainda serão construídos: "Todo texto se constrói como um mosaico de citações, todo texto é absorção e transformação de um outro texto. No lugar da noção de intersubjetividade instala-se o de intertextualidade (...).”,

\footnotetext{
7 "Bakhtine est l'un des premiers à remplacer le découpage statique des textes par un modèle où la structure littéraire n'est pas, mais où elle s'élabore par rapport à une autre structure. Cette dynamisation du structuralisme n'est possible qu'à partir d'une conception selon laquelle le «mot littéraire » n'est pas un point (un sens fixe), mais un croisement de surfaces textuelles, un dialogue de plusieurs écritures", (Kristeva, 1969 [1966], p. 83).

${ }^{8}$ Da mesma forma, Bakhtin critica a busca da especificidade dos formalistas por meio da análise do material, propondo uma nova forma de pensar a especificidade do literário. Em encontro do subgrupo coordenado pela Profa. Sheila Grillo em abril de 2012, estudamos os distanciamentos entre os ideais do Círculo de Bakhtin em relação aos formalistas. No entanto, Grillo apontou uma aproximação que está na própria busca por uma especificidade. Isto é, Bakhtin também procura a especificidade do literário, mas por meio da apreensão da obra de arte para além de sua materialidade, contrapondo-se aos formalistas.
} 
(Kristeva, 1969 [1966], p. 146) ${ }^{9}$. No tocante à definição de que um texto absorve e transforma outro, observamos uma identificação da autora com a noção de enunciado como elo na cadeia de comunicação em Bakhtin.

No último texto que compõe a obra Recherches pour une sémanalyse, "L'engendrement de la formule" (1969), Kristeva sugere o estudo da significação por meio do texto e seus tipos, disciplina denominada Semanálise. Tal disciplina pressupõe que o trabalho com o texto implica, necessariamente, no retorno à origem de onde despontam o sentido e o sujeito. Mais que uma semiologia ou semiótica, a Semanálise se construiria como uma ciência da crítica do sentido, de seus elementos e de suas leis. A Semanálise é definida, nas palavras da autora, como "teoria da significação textual, que considera o signo como o elemento especular, garantindo a representação desta criação - processo de germinação que lhe é interior.", (idem, p. 218) ${ }^{10}$.

Ao propor a Semanálise, Kristeva aponta que seu objetivo é o de captar o sistema de signos presente no interior de cada texto. Este, por sua vez, é designado como um aparelho translinguístico "que redistribui a ordem da língua, relacionando uma fala comunicativa, destinada à informação direta com diversos tipos de enunciados anteriores ou sincrônicos" (Kristeva, 1984, p. 12) ${ }^{11}$. Ainda no âmbito da Semanálise, o texto não deve ser considerado somente um fenômeno linguístico. Tampouco pode o texto existir sem a materialidade por meio da qual ocorre a significação. Em suma, o texto é descrito como um elemento linguístico dotado de sentido.

Em O texto do romance (1984), cuja publicação francesa original deu-se em 1979, Kristeva aprofunda-se na questão da intertextualidade, elaborando a noção de texto como ideologema. O conceito de ideologema corresponde à própria função intertextual materializada nos vários níveis de cada texto e que lhe confere os aspectos históricos e sociais:

\footnotetext{
9 “(...) tout texte se construit comme mosaïque de citations, tout texte est absorption et transformation d'un autre texte. A la place de la notion d'intersubjectivité s'installe celle d'intertextualité (...)", (Kristeva, 1969 [1966], p. 146).

10 “ (...) théorie de la signification textuelle, qui considère le signe comme l'élément spéculaire, assurant la représentation de cet engendrement - ce processus de germination - qui lui est intérieur.”, (Kristeva, 1969 [1966], p. 218).

11 “Qui redistribue l'ordre de la langue, en mettant en relation une parole communicative visant l'information directe, avec différents types d'énoncés antérieurs ou synchroniques.”, (Kristeva, 1979, p. 113).
} 
O ideologema de um texto é o foco em que a racionalidade cognoscente capta a transformação DOS ENUNCIADOS (a que o texto é irredutível) num TODO (o texto), e capta também as inserções dessa totalidade no texto histórico e social. [grifos da autora] (Kristeva, 1984, p. 12)

Trata-se de mais um ponto de contato entre Kristeva e a teoria do Círculo, já que a autora atribui este termo a P. N. Medviédev, - embora não cite Bakhtin nessa passagem - na obra $O$ método formal na teoria literária: introdução crítica a uma poética sociológica, de 1928. De acordo com a concepção de Medviédev/Bakhtin o ideologema é a "inter-relação entre o horizonte ideológico refletido e a estrutura artística na unidade da obra literária", (p.21) ${ }^{12}$. Tal noção foi formulada a partir do pensamento de que a literatura não toma o seu conteúdo ético e epistemológico de sistemas igualmente éticos e epistemológicos, mas do próprio processo que gera todas as ideologias. "A literatura é capaz de penetrar no laboratório social onde os ideologemas são emoldurados e formados”, (p.17) ${ }^{13}$.

Notamos que as noções apresentadas por Kristeva - a saber, o ideologema, bem como a própria elaboração da Semanálise - são elementos fundamentais para se chegar à compreensão da intertextualidade. Com base nas concepções elaboradas por Bakhtin, Kristeva postula que todo texto é permeado por outros, o princípio básico da intertextualidade para esta autora.

A intertextualidade proposta por Julia Kristeva, ainda que seja elaborada por meio de conceitos distintos, capta a noção de dialogismo tal como em Bakhtin e seu Círculo, sobretudo no tocante à relação do que é linguístico com o que é extralinguístico. Para a teoria do Círculo, as relações dialógicas são extralinguísticas ao mesmo tempo em que não podem ser separadas da concretude da língua. Na obra O problema do texto na linguística, na filologia e em outras ciências humanas (Bakhtin, 1977/ 2003), Bakhtin ressalta o lugar da língua no processo dialógico ao considerar que "do ponto de vista dos objetivos extralinguísticos do enunciado todo, o linguístico é apenas um meio" (p.313).

O interesse de Kristeva volta-se, especificamente, para o dialogismo intertextual do texto romanesco. A autora considera que a intertextualidade possa ser um fenômeno implícito ou explícito ao enunciado e, assim como ela, também consideramos que o mesmo ocorre com a hipertextualidade nos enunciados.

\footnotetext{
12 “(...) the interrelationship between the reflected ideological horizon and the artistic structure within the unity of the literary work.", (Bakhtin \& Medvedev, 1991 [1928], p. 21).

13 "Literature is capable of penetrating into the social laboratory where these ideologemes are shaped and formed", (Bakhtin \& Medvedev, 1991 [1928], p. 17).
} 


\subsubsection{A transtextualidade de Genette}

O crítico literário francês Gérard Genette elaborou uma teoria sobre as relações entre os textos e suas partes constituintes, resultando na concepção de transtextualidade. Apesar de não retomar o conceito de relação dialógica e de se tratar de uma teoria das relações estruturais entre textos literários, recorremos a Genette por três motivos: primeiramente, o autor retoma a noção de intertextualidade de Julia Kristeva; em segundo lugar, há menção à sua tipologia em estudos sobre o hipertexto; e, finalmente, Genette opera com uma noção de hipertextualidade que nos interessa. Tais fatores corroboram para a relevância da menção à sua tipologia.

Segundo o autor, a transtextualidade refere-se ao conjunto de aspectos gerais ou transcendentes revelados no gênero ou no tipo de discurso em que está inserido e nos modos de enunciação, entre outros aspectos. Trata-se de "tudo que se encontra em relação, manifesta ou secreta, com outros textos." (Genette, 1982, p.7) ${ }^{14}$. A transtextualidade, que também é denominada pelo autor de "transcendência textual do texto" (transcendance textuelle du texte), foi primeiramente descrita por Genette na obra de 1979, Introduction à l'architexte. $\mathrm{O}$ autor introduz sua ideia de texto e sua transcendência textual afirmando que

na verdade, neste momento o texto me interessa como transcendência textual, a saber, tudo que se coloca em relação, de forma manifesta ou secreta, com outros textos. Eu chamo essa relação de transtextualidade, e englobo nela a intertextualidade em senso restrito (e "clássico", desde Julia Kristeva). (1979: p. 87) 15

Nesta mesma obra, ao mesmo tempo em que o autor analisa um dos aspectos da transtextualidade, a arquitextualidade, propõe a presença de outros tipos de relação entre textos. No total, a tipologia é formada por cinco modalidades transtextuais, apontadas como aspectos da textualidade, a saber: intertextualidade; paratextualidade; metatextualidade; hipertextualidade e arquitextualidade. Na obra seguinte, Palimpsestes (1982), Genette

\footnotetext{
14 “tout ce qui met en relation, manifeste ou secret avec d'autres textes", (Genette, 1982, p.7).

15 “Mais il est de fait que pour l'instant le texte (ne) m'intéresse (que) par transcendance textuelle, savoir tout ce qui le met en relation, manifeste ou secret, avec d'autres textes. J'appelle cela la transtextualité, et j'y englobe l'intertextualité au sens strict (et <<classique >>, depuis Julia Kristeva).", [grifos do autor], (1979: p. 87).
} 
continua a desenvolver a tipologia baseada na transtextualidade, ao propor que esta engloba a arquitextualidade e qualquer outro tipo de relação transtextual (Genette, 1982, p.7).

O autor indica que as relações transtextuais não estão separadas umas das outras. Por exemplo, a arquitextualidade é constituída quase sempre historicamente, pela imitação, assim como a hipertextualidade. A hipertextualidade, por si mesma, é um arquitexto genérico, um tanto transgenérico. Outro exemplo seria o fato de que a filiação arquitextual de um trabalho é frequentemente declarada por indícios paratextuais. Por se tratar de uma categoria exclusivamente relacionada à Poética, não discorreremos sobre a noção de arquitextualidade, mas trataremos dos demais tipos de transtextualidade que poderíamos utilizar para a análise de textos não literários.

O autor atribui a noção de intertextualidade à Kristeva, tal como descreve a autora em sua obra Le mot, le dialogue et le roman (Sèméiôtikè, 1969, segundo a referência do autor). A conceituação de Kristeva serviu como base teórica para o paradigma terminológico de Genette, porém, ao contrário da que foi proposta pela autora, Genette a define de forma restrita, como a "co-presença entre dois ou mais textos (...) pela presença efetiva de um texto em outro." ${ }^{16}$ (1982, p.8), ou seja, de acordo com o autor, a intertextualidade corresponde à presença literal de um texto em outro.

A intertextualidade, sendo a convocação explícita de um texto, pode ser apresentada e distanciada por um dos três mecanismos de relação transtextual apontados pelo autor: citação, plágio e alusão. A citação é a forma mais explícita e mais literal de intertextualidade. Corresponde ao uso das aspas ou de alguma marcação no texto de um fragmento proveniente de outro texto, podendo revelar ou não sua referência de autoria. Enquanto isso, o plágio constitui-se como a forma menos explícita e menos literária de intertextualidade. Trata-se da apropriação da autoria de outrem. Finalmente, a alusão é definida como um enunciado que supõe a percepção de uma ligação com outro texto. Constitui-se como modalidade menos explícita e menos literal de relação entre os textos, porém visivelmente perceptível, ao fazer referências ao primeiro texto. O emprego desta modalidade de transtextualidade faz com que a fonte citada seja mais implícita.

O texto propriamente dito também é constituído por um tipo menos explícito de relação transtextual, o paratexto. Dentre os elementos que constituem a paratextualidade, podemos citar: o título, o lide, os prefácios, os posfácios, as notas de rodapé, as epígrafes, as

\footnotetext{
16 “coprésence entre deux ou plusieurs textes (...) pour la présence effective d'un texte dans un autre”.
} 
ilustrações, entre outros elementos textuais e "outros tipos de sinais acessórios (...) que fornecem ao texto uma linhagem (variável)". (Genette, 1982, p.9) ${ }^{17}$.

Em Palimpsestes (1982), Genette afirma que a paratextualidade possui uma série de questões ainda sem resposta. Alguns anos depois, o autor lança um livro que tratará inteiramente sobre aspectos da paratextualidade, Seuils (1987). Nesta obra, Genette afirma que, "mais que um limite ou uma fronteira precisa, (o paratexto) constitui-se como um limiar" (idem, p.7) ${ }^{18}$, uma vez que o paratexto não apresenta limite rigoroso tanto em sua relação com o interior do texto quanto em sua relação com o mundo discursivo do qual participa o texto.

O paratexto, de acordo com o autor, é composto empiricamente por um conjunto de práticas e de discursos e é formado pela soma de dois elementos, o peritexto e o epitexto. $\mathrm{O}$ primeiro corresponde à categoria espacial e é encontrado mais comumente, como, por exemplo, os títulos, intertítulos, títulos auxiliares, entre outros. Enquanto isso, o segundo equivale a tudo que está relacionado ao exterior do texto, ou até do próprio livro, ou suporte. Neste caso, o epitexto constitui uma relação paratextual distinta do primeiro, sob o ponto de vista espacial. O autor cita como exemplo uma entrevista que trata sobre uma obra e que será publicada fora dela.

O texto literário é formado por enunciados verbais e nunca está nu. É acompanhado por certo número de produções verbais ou não como título, nome do autor, prefácio e ilustrações. Logo, a paratextualidade é o aspecto transtextual que pode ser definido como o conjunto de relações estabelecidas entre o texto e seus segmentos com o que lhe é exterior.

A noção de metatextualidade é o terceiro aspecto da transtextualidade apontado por Genette em Palimpsestes (1982). Caracteriza-se pela relação transtextual entre o comentário e o texto-fonte que ele comenta. Genette cita como exemplo todas as críticas literárias que produzem um metatexto, sem necessariamente convocar o texto sobre o qual o comentário é produzido. Mais especificamente, o autor afirma que "é desta forma", por meio da metatextualidade, "que Hegel, em Phénoménologie de l'esprit, evoca, alusivamente e silenciosamente, a obra Neveu de Rameu" (p.10) ${ }^{19}$. Em sua concepção, o autor afirma que a

\footnotetext{
17 "et autre types de signaux accessoires, autographes ou allographes, qui procurent au texte un entourage (variable)", (Genette, 1982, p.9).

18 “Plus que d'une limite ou d'une frontière étanche, il s'agit ici d'un seuil”, (Genette, 1987, p. 7).

19 “C'est ainsi que Hegel, dans la Phénoménologie de l'esprit, évoque, allusivement et comme silencieusement, le Neveu de Rameu", (p.10).
} 
metatextualidade estabelece uma função crítica que aparece, na maioria das vezes, sob forma de alusão, ou seja, este tipo de transtextualidade corresponde, por excelência, à relação crítica.

O quarto elemento de sua tipologia transtextual é a hipertextualidade. O emprego do termo, no que tange a sua definição teórica neste contexto, difere da noção de hipertextualidade a que se pretende chegar nesta tese a partir da hipótese lançada na pesquisa de mestrado anterior (Machado, 2007). A hipertextualidade, neste caso, diz respeito a toda relação que une um texto $\mathrm{B}$, que Genette denomina hipertexto ${ }^{20}$, a um texto anterior $\mathrm{A}$, que ele chama de hipotexto. De acordo com o autor em Palimpsestes (1982), verifica-se uma relação de derivação discursiva de um texto a outro texto pré-existente. Tal derivação pode ser de diferentes ordens: descritiva ou intelectual, em que um metatexto fala de um texto. Considera-se, ainda, que a derivação pode ocorrer de outra maneira. Trata-se do caso em que B, apesar de não citar A, não pode existir sem A, pois resulta de uma operação que o autor qualifica como transformação e que, consequentemente, ele evoca mais ou menos claramente, sem necessariamente falar de si e o citar.

Esse modelo de hipertextualidade é elaborado por Genette a partir de sua observação sobre textos literários. Genette (1982, p.12) cita como exemplo de hipertexto os títulos "Eneida" e "Ulisses" (o autor não especifica se "Ulisses", neste caso, refere-se à obra de James Joyce) que, segundo ele, derivam do mesmo hipotexto, “A Odisséia”. Os títulos das duas primeiras obras, em relação ao título do hipotexto, constituem, respectivamente, o texto imitado e o texto imitador. Ambos possuem entre si uma relação de transformação simples ou direta que é considerada uma mediação indispensável para esta articulação transtextual.

Além da dimensão do título das obras, Genette ressalta a relação entre a totalidade das mesmas. O texto de 'A Odisséia' é tido como o texto fonte ou imitado ao passo em que "Eneida", de Virgílio, é o próprio texto imitador, sob o ponto de vista narrativo e estrutural da epopeia, tal como proposta pelo autor anterior, Homero.

O terceiro exemplo descrito trata da relação da obra 'Ulisses' de Joyce com a obra 'A Odisséia' de Homero. Enquanto Virgílio conta a história de outro personagem da mesma maneira que Homero, sob o ponto de vista estrutural da epopeia, Joyce narra a história de Ulisses a partir de um estilo próprio e de um esquema de ação com transformações simétricas e inversas em relação à obra original.

\footnotetext{
${ }^{20}$ Em Palimpsestes (1982), Genette afirma que a utilização do termo hiper- é provisória naquele momento e que ele, por vezes, preferirá utilizar o prefixo meta-. "Je renonce à chercher, pour une usage aussi transitoire, un préfixe qui submerait à la fois l'hyper- et le méta-”, (1982, p. 12).
} 
O autor postula uma classificação para as práticas hipertextuais regidas por dois critérios: o regime da relação entre os textos, podendo ser ele lúdico, sério ou satírico; e a distinção entre transformação e imitação. Dessa forma, há a possibilidade de haver seis combinações diferentes para as relações transtextuais de ordem hipertextual.

A transformação é constitutiva para as relações hipertextuais nesse contexto. "Chamo de hipertexto todo o texto que deriva de um texto anterior por transformação simples ou por transformação indireta: ou seja, imitação" (Genette, 1982, p.14) ${ }^{21}$. Neste sentido, Gerard Genette considera a hipertextualidade um aspecto universal da literatura.

A tipologia de Gérard Genette contempla diferentes aspectos da textualidade estabelecidos pelas relações estruturais entre textos. Nessa elaboração, por exemplo, a intertextualidade restringe-se à manifestação específica da citação, plágio ou alusão. Por meio da leitura de suas obras, observamos que Genette não faz referência às relações dialógicas bakhtinianas, mas baseia-se na proposta de intertextualidade de Kristeva para compor a sua tipologia. Contudo, a intertextualidade em Genette, embora tenha sido inspirada na autora búlgara, é constituída de maneira distinta. Para o autor, a intertextualidade não é constitutiva como para Kristeva que aponta uma dupla orientação intertextual do ideologema, ou seja, enquanto para Kristeva a intertextualidade é constitutiva e também aparente no enunciado, Genette considera apenas as formas explícitas ou concretas de manifestação do intertexto.

As obras de Genette colaboram para os propósitos teóricos de nossa pesquisa uma vez que as definições de intertextualidade, arquitextualidade e paratextualidade dizem respeito a relações estabelecidas entre diferentes textos, suas partes e estrutura. Mesmo que a noção de hipertextualidade em Genette não se confunda com a desta pesquisa, trata-se de uma teorização relevante, pois Genette chama a atenção para um tipo de relação textual remissiva não é necessariamente marcada por um nó remissivo. Entretanto, o aspecto primordial que distancia a abordagem estruturalista de Genette da perspectiva de uma análise dialógica sobre a hipertextualidade é a exterioridade e o entorno sócio-histórico do enunciado. Ao longo da tese, considerando o aspecto dialógico das relações entre os textos e suas partes, buscaremos depreender dos enunciados relações dialógicas articuladas por um nó remissivo e também por outros aspectos da forma composicional do gênero reportagem

\footnotetext{
${ }^{21}$ «J'appelle donc hypertexte tout texte dérive d'un texte antérieur par transformation simple ou par transformation indirect: nous dirons imitation", (Genette, 1982, p.14).
} 
de divulgação científica, tal como o emprego de elementos verbo-visuais e a própria hiperestrutura.

\subsubsection{A intertextualidade sob o enfoque da Linguística Textual}

Após depreendermos aspectos de teorias estruturalistas da literatura, passaremos a discorrer sobre o objeto da Linguística Textual (doravante LT), uma teoria do texto que não foi formulada exclusivamente com o olhar sobre o texto literário. A LT vem se mostrando bastante profícua nas análises e estudos sobre o hipertexto na última década no cenário brasileiro. Além de ter a intertextualidade como uma das noções centrais que compõe a sua conjuntura teórica, pode-se dizer que tal domínio também sofreu a influência do conceito de dialogismo da teoria do Círculo. A LT interessa-se não somente pelos aspectos estruturais que concernem o texto, mas também pelo sentido inerente à relação entre eles.

De acordo com Paveau \& Sarfati (2003, p.185), além da semiótica literária de Kristeva e Genette, a LT herdou as hipóteses estruturalistas das décadas precedentes, aspectos da retórica - antiga, clássica e a nova retórica de Perelman - e as sociolinguísticas de Labov e Goffmann. Em um contexto científico regido pela linguística frástica, a LT apropriou-se do conceito de intertextualidade primeiramente elaborado por Julia Kristeva, dando-lhe acabamento teórico específico. O foco de atenção dos estudos dessa área está voltado para o texto, cujas acepções sofreram variações ao longo das décadas. Ao lado de noções-chave como coesão, coerência e progressão temática, emerge a classificação de tipos textuais que Paveau \& Sarfati (2003, p.191) consideram uma incorporação da noção de gêneros discursivos da teoria bakhtiniana.

No âmbito da LT, o texto passa a ser concebido como espaço de constituição e interação entre sujeitos e o conceito de interação verbal proposto pelo Círculo integra-se fundamentalmente à noção de intertextualidade. Com a influência do dialogismo bakhtiniano, a ideia de que o texto estabelece sentidos a partir de seu ponto de contato com outros textos prevalece e a LT passa a considerar que "a comparação entre os textos produzidos em dada cultura permite depreender as propriedades formais, estilísticas e temáticas comuns a determinados gêneros textuais (...), bem como estruturas comuns a cada um dos tipos textuais.” (Koch, 2008, p. 16).

Sobre a relação da LT com a teoria do Círculo de Bakhtin, Koch et al. afirmam que: 
a Linguística Textual, (...), incorporou o postulado dialógico de Bakhtin (1929), de que um texto (enunciado) não existe nem pode ser avaliado e /ou compreendido isoladamente: ele está sempre em diálogo com outros textos. (2008, p. 14)

Um dos expoentes da LT no cenário acadêmico brasileiro, Ingdore Koch organiza uma tipologia sobre a intertextualidade, compreendida pela intertextualidade stricto sensu e pela intertextualidade lato sensu e suas variantes. A intertextualidade stricto sensu prevê a inserção de um texto, produzido anteriormente, em outro. Neste caso, as relações intertextuais estão concretizadas de forma aparente no texto, assemelhando-se à noção de intertextualidade proposta pela AD. Em Koch et al. (2008), as autoras apresentam a classificação desse tipo de intertextualidade, dividindo-a em quatro categorias, a saber: intertextualidade temática; intertextualidade estilística; intertextualidade explícita e, finalmente, intertextualidade implícita.

A intertextualidade temática ocorre no plano do conteúdo, sendo que é constituída pelo diálogo entre diferentes veículos, autores, publicações, ou outras instâncias de comunicação, sobre um mesmo tema ${ }^{22}$. Koch et al. (2008) exemplifica, ao afirmar que "a intertextualidade temática é encontrada entre textos científicos pertencentes a uma mesma área do saber ou uma mesma corrente de pensamento, que partilham temas e se servem de conceitos e terminologia próprios, já definidos no interior desta área ou corrente teórica.”, (p. 18).

Enquanto isso, a intertextualidade estilística é produzida quando o enunciador parodia ou utiliza elementos que reproduzam o estilo de determinado gênero ou discurso. Dentre os exemplos deste tipo de intertextualidade citados pelas autoras estão as paródias que têm como intertexto a oração do Pai Nosso e a relação intertextual estabelecida pelo texto de Paulo Leminski, Grande ser, tão veredas, com o Grande sertão veredas de Guimarães Rosa.

A intertextualidade explícita é caracterizada pelo aparecimento da menção à fonte do intertexto no próprio texto. Isso ocorre sob forma de discurso citado ou algum mecanismo de referência, como o exemplo do uso do link eletrônico em enunciados digitais: "É o caso das citações, referências, menções, resumos, resenhas e traduções” (idem, p.28). Por outro lado, a intertextualidade implícita não situa o interlocutor a respeito da proveniência das citações ali empregadas e a ativação do texto-fonte é feita de forma não marcada. Esse tipo de

\footnotetext{
22 Não no sentido de tema e conteúdo temático, tal como na teoria bakhtiniana. Neste caso, tema refere-se ao assunto.
} 
intertextualidade é articulado "quando se introduz, no próprio texto, intertexto alheio, sem qualquer menção explícita da fonte com o objetivo quer de seguir-lhe a orientação argumentativa, quer de contraditá-lo, colocá-lo em questão, de ridicularizá-lo ou argumentar em sentido contrário." (idem, p.30).

O plágio pode ser um exemplo desse tipo de intertextualidade. No entanto, devem-se considerar também os casos em que o texto-fonte é empregado sem menção à sua autoria ou sem nenhum mecanismo indicador de intertextualidade, como o uso das aspas, em contextos diferentes ao do texto-fonte. No caso de uma peça publicitária, como exemplificam as autoras, esse recurso faz com que o leitor recupere, por si mesmo, os outros contextos em que figura o texto reproduzido.

Ao introduzir o conceito de intertextualidade lato sensu, segundo elemento da tipologia intertextual da LT, como conceito amplo, Koch (2008) retoma a noção de Kristeva de que todo texto é transformação e absorção de outro. A autora também salienta que a noção de intertextualidade deriva especificamente dos estudos da Linguística Antropológica por meio dos estudos de Bauman e Briggs (1995) ao contemplarem "as relações entre gênero, intertextualidade e poder social" (Koch, 2008, p.85). Essa noção, integrante de um nível mais amplo na escala dialógica, é subdividida em duas modalidades: a intertextualidade tipológica e a intertextualidade genérica.

A intertextualidade genérica resulta da relação intertextual entre gêneros. "Os exemplares de cada gênero, evidentemente, mantêm entre si relações intertextuais no que diz respeito à forma composicional, ao conteúdo temático e ao estilo" (Koch et al., 2008: p.63), o que permite ao interlocutor que logo reconheça sua origem genérica. Partindo da premissa de que os gêneros são potencialmente dialógicos, tal como estabelece a teoria do Círculo, Koch complementa que os gêneros estabelecem relações intertextuais entre si:

os gêneros possibilitam a ordenação e a estruturação do discurso em termos históricos e sociais: os provérbios, os contos de fada, as fábulas, por exemplo, podem nos remeter a um passado tradicional, enquanto os e-mails nos remetem ao presente ultramoderno. (Koch et al., 2008, p.90)

Por sua vez, a intertextualidade tipológica caracteriza-se pela relação de aproximação ou distanciamento que é observada na produção dos gêneros discursivos e textos com tipos textuais específicos. Este tipo de intertextualidade "decorre do fato de se poder depreender, 
entre determinadas sequências ou tipos textuais e outros elementos dêiticos que permitem reconhecê-las como pertencentes à determinada classe." (idem: p. 76).

A noção de intertextualidade elaborada no âmbito da LT está diretamente relacionada com a de texto e soma-se às contribuições do Círculo acerca das relações dialógicas, aos conceitos da AD francesa, bem como recupera o pressuposto de Kristeva. Observamos, novamente, um diálogo entre diferentes domínios teóricos para o estabelecimento e acabamento do conceito de intertextualidade.

Se a noção de intertextualidade de Kristeva pode ser considerada um conceito-chave embrionário para o entendimento das relações dialógicas hipertextuais, a concepção de intertexto proveniente da LT também pode ser considerada um aspecto central. Percorrendo as obras que discorrem sobre a hipertextualidade, estudos como o de Lobo (2009) consideram a hipertextualidade como um fator de textualidade do hipertexto, tal como veremos mais adiante. Portanto, a resenha em torno das noções de texto e intertexto no âmbito da LT servirão de base para o entendimento das propostas que vinculam o intertexto a uma característica do hipertexto.

\subsubsection{Contribuições da AD francesa: interdiscursividade e heterogeneidade}

A observação de teorias estruturalistas voltadas para o texto, por meio do estudo que estamos delineando ao longo deste capítulo, indica a penetração da teoria dialógica nesses diferentes domínios, como em Kristeva e em autores da LT. Uma vez que tratamos de teorias tanto em abordagens estruturalistas, quanto da literatura e do texto, passaremos a discorrer sobre conceitos que tangem à relação entre discursos e algumas noções-chave em duas escolas âmbito da Análise do Discurso francesa. As ideias bakhtinianas tiveram uma forte recepção e divulgação no cenário francês, a partir das leituras e traduções de Kristeva e Todorov. Além disso, o dialogismo é um conceito que vem sofrendo releituras e reformulações, tal como na teoria polifônica de Ducrot, ou mesmo na noção de interdiscursividade a partir dos preceitos de Pechêux, e de heterogeneidade, segundo Authier-Revuz.

Ao longo deste capítulo, há uma mudança de foco epistemológico notável, ao partirmos da noção de intertextualidade para discutirmos questões sobre alteridade e heterogeneidade. Conforme justificamos anteriormente, além de a contribuição da teorização de Authier-Revuz ser de grande relevância para os estudos sobre o discurso, a autora alia o 
dialogismo bakhtiniano à Psicanálise. Outro fator a ser ressaltado é que há autores brasileiros que utilizam as premissas da $\mathrm{AD}$ francesa para a análise do hipertexto e das relações discursivas em meio digital.

A alteridade discursiva diz respeito à presença do outro em determinado enunciado ou discurso. Segundo teoriza Authier-Revuz, a alteridade pode ocorrer de duas formas: por meio da heterogeneidade mostrada ou da heterogeneidade constitutiva. No texto Hétérogénéité montrée et hétérogénéité constitutive: élément pour une approche de l'autre dans le discours (1982), a autora busca verificar que elementos articulam a heterogeneidade constitutiva do discurso e as formas de heterogeneidade mostrada no discurso. Tais noções foram desenvolvidas pela autora no Seminário DRLAV que ocorreu nos anos iniciais da década de 1980, publicadas na revista de mesmo nome.

Authier-Revuz disserta, primeiramente, a respeito das formas explícitas de heterogeneidade afirmando que elas são caracterizadas por certo número de formas linguísticas apreensíveis no nível da frase ou do discurso inscrito do outro. São formas marcadas de heterogeneidade mostrada. A heterogeneidade mostrada é marcada pelo aparecimento de categorias descritíveis da língua, como o discurso citado e o uso de aspas. Ao inscrever o outro no discurso por meio de mecanismos textuais, a homogeneidade dá lugar a uma heterogeneidade discursiva, que é aparente e, por isso, mostrada.

A autora define que o outro do discurso citado, direto ou indireto, designa outro ato de enunciação na frase. No tocante ao discurso indireto, o locutor torna-se tradutor ao utilizar suas próprias palavras e retomar o outro como fonte do sentido sobre o que ele reporta. $\mathrm{O}$ discurso direto, por sua vez, é constituído pelas mesmas palavras e termos empregados na citação-fonte. Segundo ela, "por meio dessas duas modalidades, o locutor dá lugar explicitamente no seu discurso ao discurso do outro" (p.92) ${ }^{23}$. Há ainda um tipo mais complexo de heterogeneidade que opera com diversas formas marcadas designadas pela autora de "conotation autonymique". O locutor faz uso da intervenção de palavras do outro, inscritas em seu discurso. Neste caso, o discurso alheio pode ser marcado pelas aspas, grifo em itálico, entonação ou qualquer outra forma de comentário.

Uma segunda modalidade de heterogeneidade mostrada é chamada de não-marcada. Esta forma pode ser constituída por discurso indireto livre, ironia, imitação, alusão, reminiscência ou estereótipo que, segundo Authier-Revuz, são "formas discursivas que

\footnotetext{
23 "Sous ces deux modalités différentes, le locuteur fait place explicitement dans son discours au discours d'une autre.”, (Authier-Revuz, p. 92, 1982).
} 
parecem poder anexar à estrutura enunciativa da 'connotation autonimyque', a presença do outro, mas que não é explicitada pelas marcas unívocas na frase (...)”, (p. 96) ${ }^{24}$.

A heterogeneidade constitutiva, por sua vez, ancora os elementos linguísticos das formas de heterogeneidade mostrada ao exterior, ao extraverbal, ou seja, toda manifestação de heterogeneidade mostrada é envolvida pela heterogeneidade constitutiva. $\mathrm{O}$ contrário não ocorre, uma vez que, na heterogeneidade constitutiva, o outro pode não ser revelado linguisticamente no discurso. A heterogeneidade mostrada, segundo hipótese da autora, corresponde a uma forma de negociação obrigatória do sujeito falante com a heterogeneidade constitutiva.

A tabela abaixo representa um esquema das formas de heterogeneidade, segundo Authier-Revuz:

Tabela (1) Formas de heterogeneidade

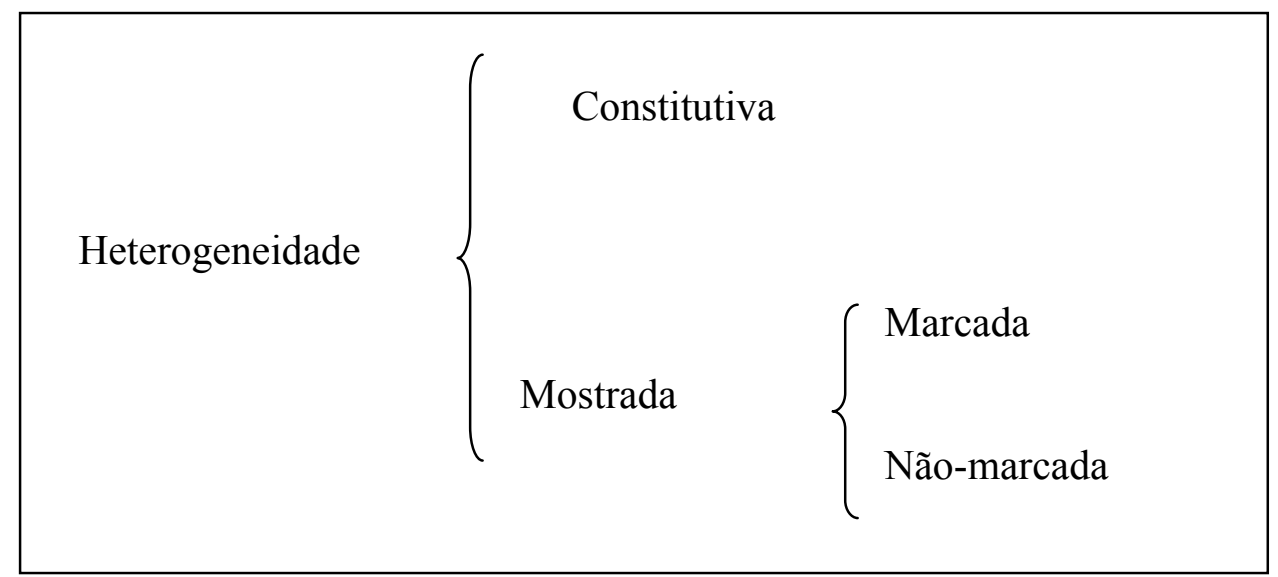

Ao formular tais noções, Authier-Revuz ancora, por um lado, a heterogeneidade no dialogismo bakhtiniano e, por outro, na Psicanálise cujo objeto, o inconsciente, não possui natureza linguística. A autora situa os trabalhos do Círculo, e consequentemente a noção de dialogismo, no âmbito da Semiótica e da Literatura ao mesmo tempo em que estabelece, de forma contrária, que a heterogeneidade proposta por ela é de abordagem linguística. Sua abordagem é linguística e apoia-se em duas fontes não linguísticas provenientes das teorias dialógica e lacaniana.

Ao operar com o dialogismo bakhtiniano, Authier-Revuz atrela este conceito aos gêneros literários que considera serem constituídos por propriedades da língua e do discurso.

24 ، (...) formes discursives qui me semblent pouvoir être rattachées à la structure énonciative de la connotation autonymique, la présence de l' autre, en revanche, n'est pas explicitée par des marques univoques dans la phrase", (Authier-Revuz, p. 96, 1982). 
A autora retoma a noção de Meta- ou Translinguística em Bakhtin para apontar para o fato de que sua teoria não se ocupa do terreno linguístico, mas reconhece a existência de dois campos distintos, sendo que um deles diz respeito à língua concreta como seu objeto. Atenta, ainda, para o uso dos termos "dialogue externe" e "dialogisation intérieure" para evidenciar esta duplicidade que articula a teoria do círculo. Esta corresponde ao discurso interior do locutor que imagina a situação concreta de enunciação, ao passo em que aquela diz respeito às formas exteriores do diálogo.

O dialogismo do círculo bakhtiniano, de acordo com Authier-Revuz, fez da interação com o discurso do outro a base constitutiva de todo o discurso. A presença do outro é designada como interdiscursividade e interlocução que são inscritas no discurso do um por meio das "palavras dos outros" (p.140). Nesse contexto, o outro não é um objeto, mas sim uma condição de constituição do discurso.

Com o intuito de desenvolver a noção de interdiscursividade no âmbito da Análise do Discurso francesa, apresentaremos a perspectiva elaborada por Michel Pêcheux (1983), bem como os desdobramentos encontrados em Maingueneau (1984 e 1991), Orlandi (2003) e Possenti (2002) a respeito de aspectos fundamentais para a constituição da interdiscursividade neste campo, a saber, memória, formação discursiva e a presença do Outro.

Uma das bases fundamentais para a AD, segundo aponta Possenti (2002), é o fato de que o diálogo entre discursos revela "os múltiplos sentidos de um mesmo texto - o que remete à ideia de que há mais de um discurso onde se poderia imaginar que há um só.” (p. 195). A partir dessa constatação, o autor atenta para o interdiscurso como objeto da AD ao afirmar que "entre as maiores contribuições da análise do discurso francesa estão sua formulação peculiar da noção de interdiscurso" (2004, p. 195), que difere em boa medida das de intertextualidade, embora aparentadas. Orlandi (2003) também diferencia interdiscurso e intertexto, apesar de afirmar que ambos mobilizam relações de sentido. No entanto, o primeiro possui como natureza o saber discursivo, "memória afetada pelo esquecimento" (p. 34), enquanto que o intertexto refere-se a um tipo específico de relação entre textos.

O dialogismo bakhtiniano pode ser apontado como conceito matriz para o surgimento tanto da noção de intertextualidade, como afirmamos na reflexão sobre a teoria de Kristeva, quanto de interdiscursividade. Ao considerar que o texto é potencialmente responsivo e que se corresponde com outros textos, observa-se que a noção de texto em Kristeva está relacionada diretamente à de enunciado em Bakhtin. Para a constituição do interdiscurso, o 
dialogismo também é fundamental. No entanto, neste contexto teórico, as relações dialógicas não ocorrem no escopo do texto ou do enunciado, mas sim, por meio de formações discursivas.

Ao apontar os pontos de convergência e divergência entre Maingueneau e as obras do Círculo de Bakhtin, Grillo \& Velloso (2008) ressaltam as relações dialógicas como elemento fundamental para a constituição da noção de interdiscurso para este teórico.

\begin{abstract}
No âmbito da análise do discurso, as relações dialógicas são inspiradoras da problemática da interdiscursividade. $\mathrm{O}$ interdiscurso compreende a relação constitutiva entre formações discursivas, no sentido de que o que é rejeitado como externo delineia as fronteiras do que é afirmado como interno e de que o surgimento de uma nova formação discursiva se dá no espaço da relação polêmica com o já dito da formação discursiva precedente. (Grillo \& Veloso, 2008, p. 249).
\end{abstract}

A proposta do Círculo está vinculada à interdiscursividade, uma vez que indica a relação com o outro como o fundamento primordial para a discursividade. No entanto, Maingueneau afirma que a $\mathrm{AD}$ opera o interdiscurso com maior exatidão em relação ao dialogismo, sob o ponto de vista metodológico. "Se em um sentido a nossa abordagem é a mesma que a perspectiva de Bakhtin, a de uma 'heterogeneidade constitutiva', porém, nós operamos em pequena escala, atribuindo a esse quadro geral uma metodologia e um domínio de validade muito exata." $\left(1984\right.$, p.27) ${ }^{25}$. Na seção seguinte, delimitaremos a especificidade que Maingueneau demonstra ser um fator de convergência entre interdiscurso e dialogismo.

Em seu texto Rôle de la mémoire, Pêcheux define a memória como a própria "estrutura da materialidade discursiva complexa" (1983, p.263) ${ }^{26}$. Para este autor, a memória forma-se a partir do entrecruzamento da memória mítica, da memória social inscrita em práticas discursivas e da memória constitutiva da história. Portanto, a memória não deve ser reduzida a "uma esfera plana, cujas bordas seriam de transcendências históricas em que o conteúdo seria um sentido homogêneo, acumulado como um reservatório" (Pêcheux, 1983, p.267). Neste caso, todo "evento histórico, descontínuo e exterior" (idem,

\footnotetext{
25 “si en un sens notre démarche s'inscrit dans la même perspective que celle de Bakhtine, celle d'une « hétérogénéité constitutive », nous opèrerons néanmoins dans un cadre restreint, assignant à cette orientation générale un cadre méthodologique et un domaine de validité beaucoup plus précis”, (Maingueneau, 1984, p.27).

26 "La mémoire comme structuration de matérialité discursive complexe (...) la mémoire discursive serait ce qui, face à un texte surgissant comme événement à lire, vient rétablir les “ implicites " qui nécessite sa lecture: la condition du lisible par rapport au lisible lui-même”, (Pêcheux, 1983, p.263).
} 
p.261) ${ }^{27}$ pode vir a inscrever-se discursivamente no espaço da memória por meio do processo de interdiscursividade.

De acordo com Orlandi (2003, p.33), "pelo funcionamento do interdiscurso, suprimese, por assim dizer, a exterioridade como tal para inscrevê-la no interior da textualidade". A memória pode proceder de duas ordens (Orlandi, 2003): (a) a memória institucionalizada, o arquivo, e (b) a memória constitutiva, cujo trabalho histórico da constituição do sentido equivale ao interdiscurso, ou seja, em sua segunda acepção, a memória constitutiva equivale ao próprio interdiscurso.

Este (o interdiscurso) é definido como aquilo que fala antes, em outro lugar, independentemente. (...) é o que chamamos de memória discursiva: o saber discursivo que torna possível todo dizer e que retorna sob a forma do préconstruído, do já-dito, que está na base do dizível, sustentando cada tomada da palavra. (Orlandi, 2003, p. 31)

Portanto, a $\mathrm{AD}$ opera com a noção de memória ao relacionar a linguagem à sua exterioridade por meio do interdiscurso, que é “todo o conjunto de formulações feitas e já esquecidas que determinam o que dizemos" (Orlandi, 2003, p. 34).

A segunda noção fundamental para o entendimento do processo de interdiscursividade é a noção de formação discursiva. A produção de sentidos ocorre a partir do momento em que o sujeito inscreve o seu discurso em uma dada formação discursiva específica, ou seja, o sentido é articulado a partir de um discurso dotado de ideologia que se concretiza na materialidade linguística por meio das formações discursivas.

A relação entre essas diversas formações discursivas gera a interdiscursividade, ou melhor, pode-se considerar que as formações discursivas são dominadas pelo interdiscurso. Orlandi (2003, p.43-44) afirma que "o interdiscurso disponibiliza dizeres, determinado, pelo já-dito, aquilo que constitui uma formação discursiva em relação à outra”.

De acordo com esta perspectiva, a AD considera que o sujeito, por sua vez, não acessa o interdiscurso ou a exterioridade que o constitui, mas determina o seu dizer sendo também determinado pela exterioridade e é por meio do interdiscurso que trava a sua relação com o outro.

\footnotetext{
27 “Cette question a conduit à aborder les conditions (mécanismes, processus...) dans lesquelles un événement historique (un élément historique discontinu et extérieur) est susceptible de venir s'inscrire dans la continuité interne, dans l'espace potentiel de cohérence à une mémoire", (Pêcheux, 1983, p.261).
} 
O interdiscurso significa justamente a relação do discurso com a multiplicidade de discursos, ou seja, ele é um conjunto não discernível, não representável de discursos que sustentam a possibilidade mesma do dizer, sua memória. Representa assim a alteridade por excelência (o Outro), a historicidade. (ORLANDI, 2003, p. 80).

Maingueneau (1984) distingue os dois modos de presença do outro no discurso: a heterogeneidade mostrada e a heterogeneidade constitutiva, tal como elaborado por AuthierRevuz, aspectos que foram detalhados no item anterior. A primeira vale-se de mecanismos linguísticos e discursivos que permitem a apreensão da menção ao outro, ou da alteridade, de forma explícita. Ao passo em que a segunda não traz consigo marcas visíveis desta alteridade em que "as palavras, os enunciados de outrem estão intimamente ligados ao texto de forma que não podem ser apreendidos por uma abordagem linguística stricto sensu” (p.25) ${ }^{28}$. É neste contexto, o da heterogeneidade constitutiva, que Maingueneau configura o interdiscurso.

\begin{abstract}
O interdiscurso é o espaço onde se constituem ou se articulam os objetos que estão em seu "intradiscurso" com a ilusão de exprimir "seus" pensamentos e de falar das coisas do mundo, marcado pelo esquecimento da palavra "pré-construída" a partir destes elementos. ${ }^{29}$. [grifos do autor] (Maingueneau, 1991, p.152)
\end{abstract}

Segundo o autor, o interdiscurso não é somente um conjunto de circunstâncias em torno do discurso, mas constitui-se como uma modalidade deste discurso que atravessa o processo de enunciação do sujeito. O interdiscurso é anterior ao próprio discurso. Por meio desta afirmação, Maingueneau retrata a necessidade de uma abordagem analítica capaz de revelar esse discurso transversal.

Retomando os conceitos apresentados, temos que os eventos históricos geram sentidos diversos quando são inscritos no espaço da memória, pois passam a ser formações discursivas. Logo, a interdiscursividade, segundo a $\mathrm{AD}$, pode ser delineada como o processo pelo qual essas formações discursivas relacionam-se entre si. $\mathrm{Na}$ seção dedicada à

\footnotetext{
28 “les mots, les énoncés d'autrui y sont si intimement liés au texte qu'ils ne peuvent être appréhendés par une approche linguistique stricto sensu", (Maingueneau, 1984, p.25).

29 "Pour lui l'interdiscours est l'espace où se constituent et s'articulent les objets qu'il lie dans son $<<$ intradiscours $>>$ avec l'illusion d'exprimer $<<$ ses $>>$ pensées et de parler des choses du monde, oublie qu'íl est du caractere $<<$ préconstruit $>>$ de ces éléments", (Maingueneau, 1991, p.152).
} 
hipertextualidade, retomaremos a noção de interdiscursividade, sobretudo no que tange à sua relação com a intertextualidade.

\subsection{As abordagens teóricas no âmbito dos estudos sobre o hipertexto}

Os estudos sobre o hipertexto tomaram grande proporção no cenário nacional pouco tempo após a abertura da internet para uso comercial em 1995, mais especificamente, a partir dos anos 2000. Várias questões surgiram não somente da problematização a respeito do tipo de leitura propiciado por esse tipo de estruturação textual pelo advento da tecnologia digital, mas também da emergência de gêneros no meio digital e seus enunciados, que tiveram seus mecanismos de articulação potencializados. As esferas da atividade humana, por meio dos diversos gêneros que a permeiam, estão se tornando mais complexas a partir da ampliação da internet e o interesse acadêmico pelo hipertexto é crescente. Logo, houve a necessidade de descrevermos os modos de funcionamento do hipertexto e estabelecer parâmetros teóricos que o enquadrassem no âmbito dos estudos da linguagem.

A apresentação do atual estado da arte no domínio dos estudos sobre o hipertexto justifica-se exatamente pela existência de inúmeras correntes teóricas que embasam as diferentes noções sobre hipertexto e hipertextualidade. Não somente provenientes de abordagens sobre o texto, o discurso ou a linguagem, mas as definições surgem de áreas afins, como a Filosofia, ou até mesmo de áreas como a Comunicação e a Informática. Tal cenário multidisciplinar exige que também tomemos um posicionamento teórico que nos ajudará a formular a noção de hipertextualidade como uma das formas pelas quais se manifestam as relações dialógicas entre enunciados. Assim, delineamos de imediato dois princípios fundamentais que nortearão o desenvolvimento da nossa tese. O primeiro deles diz respeito à própria definição de hipertexto e o segundo refere-se à distinção entre as noções de hipertexto e hipertextualidade para o contexto de nossa pesquisa.

Partimos da afirmação do filósofo canadense Pierre Lévy (1999) que descreve o hipertexto como

uma formação não-linear de apresentar e consultar informações. Um hipertexto vincula as informações contidas em seus documentos (ou "hiperdocumentos", como preferem alguns) criando uma rede de associações complexas através de hyperlinks ou, mais simplesmente, links. (Lévy, 1999, p.254) 
A afirmação de Lévy, amplamente utilizada pelos pesquisadores do hipertexto no âmbito dos estudos da linguagem, é bastante satisfatória. Ao mesmo tempo em que o descreve, sob o ponto de vista de suas características tecnológicas, como uma formação nãolinear de vinculação de documentos, o autor ressalta a sua potencialidade dialógica ao discorrer sobre as associações complexas geradas pelos nós remissivos. Levando em conta toda a sua materialidade tecnológica, mas direcionando o nosso pensamento à sua função metalinguística no sentido bakhtiniano, consideramos o hipertexto como um conjunto formado por uma rede de dois ou mais enunciados interligados por algum tipo de mecanismo ou dispositivo remissivo. Com isso, o segundo princípio sobre o qual nos apoiaremos levanos a propor que a noção de hipertextualidade deve desprender-se da de hipertexto, ao configurar-se como o tipo de relação dialógica que permeia os enunciados dispostos em rede. Adiante, veremos que nem sempre os autores atentam para a distinção entre os dois conceitos, tomando um pelo outro, ou mesmo atribuindo o que entendemos por hipertextualidade ao fenômeno da intertextualidade, como um fator de textualidade inerente ao hipertexto.

\subsubsection{O estado da arte das concepções sobre hipertexto}

O panorama dos estudos sobre o hipertexto ainda apresenta divergências no tocante a algumas questões de cunho termino-epistemológico. No quesito terminológico, para se referir ao hipertexto em meio digital, observa-se a ocorrência dos termos "hipertexto internetiano" (Marcuschi, 2000) e "hipertexto virtual" (Galli, 2004). No âmbito de nossa pesquisa, não selecionaremos um ou outro termo por uma questão de praticidade, uma vez que estamos lidando com o hipertexto tanto em meio digital quanto impresso. Optaremos pela indicação 'hipertexto em meio impresso' e 'hipertexto em meio digital' de acordo o meio em que os enunciados em rede foram concretizados.

Cada meio de veiculação do hipertexto propicia a potencialização de uma de suas características de sua forma composicional. O hipertexto constituído pela presença de nós remissivos de diferentes ordens, como elementos linguísticos ou não linguísticos, é mais produtivo no meio digital, enquanto aquele proveniente de uma forma de estruturação que coloca enunciados em relação hipertextual, como a hiperestrutura, é mais típico do impresso. No entanto, é possível encontrar enunciados em relação hipertextual por meio da estruturação modular dos textos no meio digital, assim como há a representação de nós remissivos no impresso, ainda que não se faça possível o acesso imediato ao documento 'linkado'. Nossa 
proposta é a de diferenciar a origem de veiculação do hipertexto, indicando o meio em que foi situado.

Conforme indicamos anteriormente, a divergência entre os autores ocorre não somente no âmbito terminológico, mas também no plano das definições. Por exemplo, Marcuschi (2004) descentraliza o caráter não linear da hipertextualidade e elege a presença do nó remissivo como seu fator definidor. Já para Levy (1999, p.33), o hipertexto possui tanto a dimensão técnica quanto funcional e atenta para o fato de que o hipertexto em meio digital resulta de um conjunto de interfaces emprestadas de outras mídias e pode ser definido por um “conjunto de nós ligados por conexões. Os nós podem ser palavras, imagens, gráficos ou parte de gráficos, sequências sonoras, documentos complexos que podem eles mesmos serem hipertextos".

Ao considerar que "a abordagem mais simples do hipertexto é descrevê-lo, em oposição a um texto linear, como um texto estruturado em rede", Levy (1999, p.55), ressalta que a estrutura não-linear do texto também ocorre, cada vez mais, em enunciados impressos, como se pretende apontar na análise dos dados desta pesquisa. Sob o ponto de vista técnico, o autor define o hipertexto com um sistema para a visualização de informação cujos documentos contêm referências internas para outros documentos por meio de nós.

Além de descrever o hipertexto no tocante às suas características técnicas, o filósofo se atém a uma noção mais ampla relacionada aos diferentes mundos de significação do hipertexto. Segundo o autor, “o hipertexto é talvez uma metáfora válida para todas as esferas da realidade em que as significações estejam em jogo" (1993, p. 25).

Participando de universos de sentido distintos, o hipertexto mobiliza atores de comunicação e mensagens por meio de seis princípios abstratos: o da metamorfose, que se refere à construção constante da rede hipertextual; o da heterogeneidade, que estipula a natureza heterogênea dos nós remissivos e suas conexões; o da multiplicidade e de encaixe de escalas, em que o hipertexto revela estar sempre conectado a uma rede maior apresentando-se como um fragmento do todo; o de exterioridade, no sentido de que a sua composição em rede deve ser sempre alimentada por elementos externos; o de topologia, uma vez que os hipertextos relacionam-se entre si por meio de fatores de proximidade; e o de mobilidade dos centros, que aponta a falta de centralidade da rede refletida nos seus centros múltiplos e movediços.

Uma outra concepção sobre o papel dos nós remissivos pode ser observada em Xavier (2002), cuja tese toma o hipertexto como uma nova tecnologia intelectual que "possibilita a organização das informações em uma base de dados a partir da qual se pode 
efetuar uma leitura necessariamente não linear, (...) através dos hiperlinks" (p.23). A definição do autor destaca-se por considerar o hipertexto como modo de enunciação digital:

Para viabilizar tais atividades múltiplas, esse modo de enunciação é constituído por textos escritos, sons, imagens, ícones, animações. Esses elementos, certamente, conferem agilidade, dinamismo, flexibilidade no processo de absorçãocompreensão de signos, além de garantir uma maior interatividade com os diversos objetos de conhecimento envolvidos e expostos no computador plugado à rede. (2002, p.23-24).

Em outro momento, Xavier afirma que o hipertexto "é um espaço virtual inédito e exclusivo no qual tem lugar um modo digital de enunciar e construir sentido.”, (2007, p.24), definindo-o como uma tecnologia de enunciação. A acepção de 'processo de enunciação' e 'enunciado', empregados por ele nesse momento, parece participar da proposta teórica dos autores da LT e, nesse sentido, a intertextualidade configurar-se-ía como uma característica do hipertexto.

A intertextualidade não é a única característica que vem sendo atribuída ao hipertexto. Koch (2007) elenca uma série de outros fatores constitutivos do hipertexto, tais como: a não-linearidade; a volatilidade; a espacialidade tipográfica; a fragmentaridade; a multissemiose; o multicentramento ou a descentração; a interatividade e a intertextualidade; a conectividade; a virtualidade.

A não linearidade ou deslinearização é vista como um dos principais fatores presentes na produção do hipertexto. De acordo com Xavier (2004, p.175) “inovação trazida pelo texto digital eletrônico está em transformar a deslinearização, a aparente ausência de um foco dominante de leitura, em princípio básico de sua construção". A não-linearidade do hipertexto, também transposta ao meio impresso, localiza-se nas escolhas de qual caminho de leitura o usuário quer trilhar a fim de construir um sentido que lhe seja próprio e oportuno por meio dos nós. O sentido vai sendo estabelecido na relação entre os enunciados e o indivíduo encontrará novas significações a cada escolha no percurso discursivo de leitura. A deslinearização está relacionada com outro aspecto, a descentração que pode levar à possibilidade de um deslocamento indefinido de tópicos.

Os aspectos de espacialidade tipográfica são caracterizados, respectivamente por Koch (2007), como a natureza do suporte, que gera a volatilidade, e o espaço não-hierarquizado de escritura e leitura de limites indefinidos. Enquanto isso, a fragmentaridade refere-se à falta de um centro regulador imanente do enunciado hipertextual. 
Segundo Koch (2007), a multissemiose é outra característica marcante do hipertexto por viabilizar a absorção de diferentes signos e elementos sensoriais, como itens lexicais, sons, diagramas, entre outros numa mesma superfície de leitura. Esse caráter pode ser relacionado com a noção de hiperestrutura de Lugrin (2001) que será apontada como uma das categorias descritivas da análise, além de ser entendida por nós como uma forma de estruturação de textos que formam um enunciado hipertextual.

Ao observar os traços de textualidade constitutivos do hipertexto apresentados por Koch (2007) chegamos às duas considerações importantes para nossa reflexão. A primeira delas é que traços tais como a interatividade, a conectividade e a virtualidade são características pertinentes ao meio digital e que, portanto, não são observadas no hipertexto em meio impresso. Isso torna a nossa pesquisa ainda mais instigante no tocante à análise das relações de sentido estabelecidas no hipertexto em cada meio. A segunda diz respeito à problemática da intertextualidade como um traço de textualidade do hipertexto e que discutiremos detidamente na seção seguinte em contraponto com a noção de hipertextualidade que estamos formulando.

Antes de discorrermos sobre a visão do hipertexto e dos nós remissivos sob o ponto de vista da teoria dialógica da linguagem, ressaltamos a proposta de Lobo (2009). A partir das definições de Xavier (2002 e 2007), Lobo reafirma o hipertexto enquanto modo de enunciação digital. $\mathrm{O}$ ponto de convergência entre os dois autores gira em torno dos aspectos caracterizadores esse modo de enunciação. A autora disserta sobre o hipertexto em oposição à hipertextualidade e afirma que, enquanto o primeiro é a manifestação do modo de enunciação digital, o segundo é o processo "ontológico" maior, ou seja, todo hipertexto pressupõe a hipertextualidade, mas esta ocorre independentemente por constituir-se como a natureza do processo enunciativo do qual participa o hipertexto.

O hipertexto, sendo porção da hipertextualidade, é um modo de enunciação digital que se caracteriza tendo em vista a natureza de sua interação e os gêneros digitais que faz emergir. Diferentemente da hipertextualidade, enquanto enunciação digital maior, o hipertexto é sempre aquilo que se permite flagrar. (Lobo, 2009, p. 145).

Diversos estudos discorrem sobre a presença da hipertextualidade, mas, como aponta Lobo (2009), muitos tomam a hipertextualidade por hipertexto e vice versa. A afirmação da autora corrobora com o que estabelecemos logo no início da seção. O hipertexto refere-se ao enunciado concretizado possuidor de algum mecanismo remissivo que o conecta a a outros 
enunciados. A hipertextualidade, que Lobo (2009) denomina 'enunciação digital maior', seria uma instância dialógica da linguagem.

Encerrando a apresentação do panorama amplo sobre as definições de hipertexto, registramos uma abordagem fundamentada em ideais bakhtinianos. No que tange aos nós remissivos, partiremos do pressuposto de que as relações estabelecidas por eles não são puramente linguísticas, mas constituem-se como relações semânticas, de ordem dialógica. Segundo Bakhtin, "a relação com a coisa (em sua materialidade pura) não pode ser dialógica (...)”. A relação com o sentido é sempre dialógica.” (1979, p.327), ou seja, o processo dialógico não se dá por conta da materialidade da língua e dos aspectos puramente linguísticos, apenas se vale deles para estabelecer as relações de sentido. Ao estabelecer relações semânticas entre enunciados, a articulação remissiva decorrida do nó já se torna um primeiro indício de que a hipertextualidade gerada constitui-se como uma modalidade de relação dialógica da linguagem.

Tomando a noção de enunciado como sendo um elo na cadeia da comunicação verbal, tal como proposta pelo círculo de Bakhtin (1952-53 / 2003), temos o nó remissivo funcionando como um dos elos. O diálogo entre diferentes enunciados torna-se possível porque o nó funciona como um ponto de contato entre dois enunciados.

\subsubsection{A intertextualidade e a hipertextualidade no hipertexto}

Uma reflexão sobre a intertextualidade em contraposição à hipertextualidade no hipertexto torna-se importante para a demarcação de nosso posicionamento teórico. Como dissemos anteriormente, a multidisciplinaridade e a diversidade de definições pertinente a essa área levam-nos a refletir sobre os princípios epistemológicos embasadores de nossa tese. Além da problemática da não distinção entre as noções de hipertexto e hipertextualidade que já apontamos no capítulo, há autores que compreendem a intertextualidade como um de seus elementos constitutivos. Tal fato faz-nos pensar sobre qual seria a relação entre inter e hipertextualidade. Portanto, a fim de melhor delimitarmos a discussão sobre o hipertexto, retomamos a consideração que fizemos a partir das características atribuídas por Koch (2007).

De acordo com a tipologia traçada pela autora, a intertextualidade configura-se como um fator de textualidade constitutivo do hipertexto juntamente com a não-linearidade; volatilidade; a espacialidade tipográfica; a fragmentaridade; a multissemiose; o multicentramento ou a descentração; a interatividade; a conectividade; e a virtualidade. $\mathrm{Na}$ 
mesma obra, a autora indica a centralidade da intertextualidade para a formação do hipertexto, como vemos a seguir:

A partir das conceituações aqui apresentadas, podemos elencar as principais características que vêm sendo apontadas para o hipertexto: intertextualidade - o hipertexto é um "texto múltiplo", que funde e sobrepõe inúmeros textos que se tornam simultaneamente acessíveis a um simples toque de mouse. (Koch, 2007, p.25). [grifos meus]

Outros autores definem a intertextualidade como uma caraterística intrínseca ao hipertexto na esteira dos conceitos da LT, tal como Marcuschi (1999) e Komesu (2005). A especificidade em Pinheiro (2005) e Xavier (2004) é a observação a respeito da infinitude que a intertextualidade propicia ao hipertexto. Segundo a primeira autora,

a intertextualidade é uma característica encontrada em qualquer texto, segundo analistas do discurso. No hipertexto, ela é infinita, visto que os leitores poderão acessar em tempo real os outros textos que estão relacionados àqueles que se está lendo. (Pinheiro, 2005, p137). [grifos meus]

Enquanto isso, Xavier (2004) discorre sobre a elaboração de um tipo específico de intertextualidade potencializada e encontrada somente no hipertexto, a intertextualidade infinita. Para o autor, a possibilidade de recuperação de enunciados por meio da arquitetura hipertextual faz com que a intertextualidade tenha esta característica de infinitude. Mesmo assim, não deixa de situar a intertextualidade como traço de textualidade do hipertexto.

No entanto, encontramos em Lobo (2008) uma preocupação na redefinição dos conceitos de hipertexto e intertextualidade e sua relação que, segundo ela, participa de um cenário acadêmico apoiado em um consenso geral - que, a partir das afirmações citadas, deve considerar a intertextualidade como traço do hipertexto.

Outra característica do hipertexto que merece discussão é a intertextualidade. Quando se fala de intertextualidade no hipertexto, constata-se que certas afirmações parecem cair no consenso geral e de tantas vezes ditas e repetidas tornam-se verdades incontestáveis. Assim, contestar que haja intertextualidade no hipertexto é sem dúvida um desatino teórico quando se tem por pressuposto o dialogismo bakhtiniano segundo o qual todo discurso é essencialmente dialógico, porque "sempre responde (no sentido lato da palavra) de uma forma ou de outra, a 
enunciados do outros anteriores". (BAKHTIN, 1997:319) [(Lobo, 2008, p. 5)]. [grifos meus]

O hipertexto acentua a função e as vantagens da intertextualidade (...). (Xavier, 2002, p.32) (...) O hipertexto é uma tecnologia enunciativa nova com características próprias em relação ao texto impresso. Este fato evidenciou-se quando da comparação dos traços que diferenciam aquele deste (...): imaterialidade, confluência de modos enunciativos, linearidade, intertextualidade infinita. (Lobo, 2008, p.202). [grifos meus]

Seguindo a sua linha de raciocínio, a autora afirma que a intertextualidade é realidade fundamental do hipertexto e atribui a isso a sua filiação teórica proveniente da noção de dialogismo do Círculo. Segundo Lobo (2009), a intertextualidade é constitutiva do texto, do hipertexto e da linguagem humana. Ao mesmo tempo, a autora ora considera o hipertexto como traço da intertextualidade, ora como unidade de análise da hipertextualidade.

Dialogando com os estudos apresentados, confrontaremos algumas posições. A primeira decorre de uma questão teórica sobre a intertextualidade, que foi inicialmente discutida neste capítulo. Portanto, quando se atribui à intertextualidade um caráter constitutivo, como faz Lobo, toma-se o conceito de intertextualidade pelo que entendemos por dialogismo no escopo da teoria bakhtiniana. Quanto à definição da intertextualidade como traço do hipertexto, levamos em conta que os autores a tenham tomado como um fator de textualidade, tal como designa a LT. Em nossa tese, tomamos uma acepção epistemológica diferente dessa. Não consideraremos a intertextualidade como um aspecto do hipertexto como se fosse parte constitutiva e fundamental desse. Logicamente, intertexto e hipertexto, bem como as relações dialógicas por eles estabelecidas, respectivamente, intertextualidade e hipertextualidade podem ocorrer em um mesmo enunciado. Contudo, para a proposta teórica que se pretende alavancar, a nosso ver, trata-se de fenômenos dialógicos independentes manifestados de forma distinta, como descrevemos em seguida.

A hipertextualidade aparece como uma especificação das relações dialógicas presentes nas estruturas hipertextuais ou nas hiperestruturas enquanto a intertextualidade seria caracterizada pela inserção de fragmentos de outros textos para o interior de um enunciado, possibilitando a presença de outro tipo de relação dialógica. O nó não materializa o texto citado, como faz o intertexto, mas o presentifica, ou seja, leva a um diálogo com outros enunciados, estabelecendo uma relação semântico-axiológica, tal como apontada por Bakhtin, e remetendo para fora do texto, de acordo com a escolha do leitor. Logo, as 
remissões a outros enunciados encontradas no hipertexto serão consideradas relações dialógicas hipertextuais por serem constituídas por esse movimento ao exterior do enunciado a partir do ponto de vista do leitor.

\subsection{Hipertextualidade e relações dialógicas}

Com o intuito de desenvolver o conceito de hipertextualidade como um tipo de relação dialógica que se aplica a enunciados que possuem qualquer articulação por meio de nós remissivos, partimos dos preceitos da teoria do Círculo de Bakhtin, não sem antes conhecer a apropriação que algumas teorias do texto, da literatura e do discurso fizeram da noção de dialogismo. Buscamos estudos sobre intertextualidade, interdiscursividade, heterogeneidade, hipertexto e hipertextualidade correntes. Além disso, verificamos a forma com que o dialogismo foi apreendido por outras teorizações, tal como a noção de heterogeneidade de Authier-Revuz e interdiscursividade segundo a AD francesa.

O estudo do deslocamento da noção de dialogismo no escopo de algumas teorias, além de ampliar nosso conhecimento sobre a própria noção tal como formulada no contexto teórico-filosófico do Círculo, também nos permite compreender o posicionamento dos autores que discorrem sobre o hipertexto e a hipertextualidade atualmente. Em seu artigo, Paveau (2010) reflete sobre a recepção do dialogismo bakhtiniano, sobretudo pela AD francesa, e constata que o apagamento das origens teóricas e de formulação do conceito contribuíram para um processo de essencialização e gramaticalização. Com isso, a autora ressalta a importância de conhecermos a teoria que serviu de matéria-prima para o desenvolvimento de outros pensamentos teóricos. Tal constatação coincide com o estudo proposto ao longo desse capítulo que buscou compreender não somente a própria noção de dialogismo, mas também a sua apreensão em outros domínios teóricos.

Antes mesmo de voltarmos à questão da hipertextualidade, devemos dizer que não estamos propondo tal conceito como unidade epistemológica no âmbito de uma nova teoria, ou ainda, um deslocamento da noção de dialogismo. Tomamos a hipertextualidade como uma relação dialógica entre enunciados, favorecida por aspectos da forma composicional e demais elementos constitutivos dos gêneros discursivos. A partir da metalinguística, bem como dos procedimentos metodológicos e analíticos que apresentaremos nos próximos capítulos, visamos à elaboração de um dispositivo de análise metalinguística, em sua acepção bakhtiniana, a fim de identificar as relações hipertextuais e os sentidos por elas produzidos. 
Ao contrário da posição adotada por Authier-Revuz que delimita a heterogeneidade mostrada nos limites da Linguística fazendo fronteira com a AD francesa e a Psicanálise, a hipertextualidade baseada nos preceitos de Bakhtin posiciona-se no nível do enunciado como unidade da comunicação discursiva e é de natureza metalinguística. Como afirmamos anteriormente, as relações estabelecidas pelos nós não são puramente linguísticas, mas sim, antes de tudo, relações de sentido, uma vez que "a relação com a coisa (em sua materialidade pura) não pode ser dialógica (...). A relação com o sentido é sempre dialógica. A própria compreensão já é dialógica." (Bakhtin, 1952-53 / 2003, p.327). A compreensão conferida ao processo dialógico não se dá por conta da materialidade da língua, apenas se vale dela para estabelecer as relações de sentido.

Finalmente, recorremos à ideia de Levy (1996) que postulou o que tomamos como indício para a hipertextualidade como instância dialógica da linguagem. Logo, o hipertexto dissolveria as fronteiras nítidas do texto, fazendo possível pensar que a hipertextualidade não é só manifestada pela presença do hipertexto. Partindo da ideia de que o hipertexto configura-se como um aspecto da forma composicional do enunciado, dentre seus demais elementos constitutivos, procuraremos observar a articulação do dialogismo hipertextual. Portanto, a análise do hipertexto no corpus é apenas uma, dentre outros aspectos da forma composicional do gênero e seus demais elementos constitutivos, das medidas por meio da qual buscamos depreender a manifestação da hipertextualidade a fim de dar conta do exame das relações dialógicas entre os enunciados e sua constituição real.

\subsubsection{A hipertextualidade e o gênero reportagem de divulgação científica impresso e digital}

Propomos que a hipertextualidade seja um elemento influenciador dos gêneros discursivos, especificamente do gênero reportagem de divulgação científica. Na pesquisa de mestrado anterior, em que comparamos artigos e reportagens, pudemos constatar de que maneira o estilo que caracteriza o gênero propicia ou não o fenômeno hipertextual. As reportagens, de caráter mais informativo e menos autoral, apresentaram um maior índice de nós remissivos e as relações dialógicas hipertextuais encontradas entre os enunciados foram maiores do que as encontradas em artigos, por sua vez, mais autorais. Exatamente onde o estilo do autor é mais saliente, o espaço para relações hipertextuais é menor, uma vez que o interessante é ressaltar a opinião daquele sujeito. A reportagem leva o leitor a outras opiniões, dados e informações, enunciados pelo autor. 
$\mathrm{Na}$ tese atual, a questão do estilo do gênero reportagem como fator que potencializa o dialogismo hipertextual será analisada junto ao corpus, assim como o conteúdo temático dos enunciados. O tema desses enunciados está exatamente na relação de sentido emergente da hipertextualidade, em que os textos são articulados a fim de se formar um hipertexto resultando em uma apreensão x ou y da realidade. Se um leitor faz a relação entre o texto a e $\mathbf{b}$, da mesma forma com que faz a relação entre b e a no jornal impresso, mas não consegue recuperar as mesmas relações de sentido entre b e a no jornal digital, logo, o conteúdo temático sofrerá uma disparidade entre os meios. No entanto, é a partir da forma composicional do gênero reportagem de divulgação científica, tanto em meio impresso, quanto em meio digital, que formularemos nosso dispositivo de análise, mais especificamente por meio de aspectos como a hiperestrutura e os nós remissivos.

Um hipertexto pode ser considerado um enunciado formado por outros enunciados que são ligados por meio de um dispositivo de remissão. Um enunciado a, que é situado sócio-historicamente, possui autoria e é direcionado a um interlocutor com características específicas - o leitor presumido -, está em relação de sentido com enunciados anteriores, publicados pelo mesmo jornal, ou pertencentes a um plano maior, até de esferas distintas. Naquele enunciado a, podemos verificar a presença de outros discursos, do discurso científico, no caso, e do próprio discurso jornalístico, uma vez que os enunciados constitutivos de uma reportagem de DC emergem na fronteira entre, pelo menos, essas duas esferas.

Dentre as relações de sentido de diversas ordens, explícitas ou não, temos um tipo de relação dialógica que funciona da seguinte forma: um dispositivo de remissão que pode ser representado por um aspecto linguístico, extralinguístico ou verbo-visual, acompanhado por algum tipo de elemento de ordem simbólica ou icônica. Tal dispositivo faz com que o enunciado a relacione-se com o enunciado b que também é formado em seu próprio grau de complexidade dialógica. Com isso, temos uma relação dialógica hipertextual e um novo enunciado, um hipertexto que possui as suas próprias relações dialógicas constitutivas.

Torna-se importante observar que o hipertexto só é formado se, de fato, o interlocutor acessa o enunciado indicado e, consequentemente, as relações de sentido sugeridas no próprio momento de produção daquele enunciado pelo autor. Por isso, o meio em que o enunciado é concretizado influi nas relações de sentido e na constituição dos hipertextos. $\mathrm{Na}$ versão digital, nem sempre há a mesma relação hipertextual que pode ser observada na versão impressa. O enunciado a está voltado para um objeto discursivo e possui um direcionamento dado pelo autor. Contudo, a presença de um nó faz com que haja a indicação 
para um novo objeto discursivo. No caso de uma reportagem, a tendência é o autor utilizar o nó para acrescentar informações, complementar o que está sendo dito, ou buscar fontes que corroborem com os dados ali apresentados, contudo, cabe ao leitor a escolha do percurso a ser tomado.

A interatividade em maior grau possibilitada pela internet faz com que os interlocutores tenham mais autonomia nas escolhas de percurso de leitura e por isso, as relações dialógicas surgidas a partir da escolha do leitor são multiplicadas. No interior de um livro, o percurso de leitura pode ser não linear, mas as fronteiras do enunciado são conhecidas, enquanto na rede, a conclusibilidade de dado enunciado, estabelecida pela alternância entre autores e pela unidade composicional, não coincide com a sua unidade temática dependendo das relações dialógicas estabelecidas pelo interlocutor. O leitor apreende o tema de um enunciado, mas dependendo do percurso de leitura, pode extrair sentidos distintos.

De acordo com a teoria bakhtiniana, os enunciados, enquanto signos ideológicos, são determinados pelas formas de interação social, influenciados pelo horizonte social formado por interlocutores de toda uma época. Em Marxismo e Filosofia da Linguagem (2004 [1929]), os autores perguntam-se sobre o que determina a refração e a reflexão do ser no signo: "aquilo que torna o signo ideológico vivo e dinâmico faz dele um instrumento de refração e de formação do ser" (p.47). Mais adiante, Bakhtin/Volóchinov afirmam que "a estrutura da enunciação é uma estrutura puramente social. A enunciação como tal só se torna efetiva entre falantes” (p.127). O sistema de remissão entre enunciados no hipertexto é movido pela interatividade em tempo real de usuários na rede o que evidencia a participação do interlocutor como corresponsável pela formação de relações de sentido.

Com isso, buscamos observar diferentes planos de remissão no corpus que caracterizam tipos distintos de relação dialógica: 1. relação dialógica hipertextual no enunciado e entre suas partes constituintes; 2. relação dialógica hipertextual entre enunciados da FSP; 3. relação dialógica hipertextual entre enunciados da FO; e 4. relação dialógica hipertextual entre enunciados da FSP e da FO. Mesmo sendo compostos das mesmas formas lógicas e juízos de valores, os enunciados da FSP e da FO são distintos. O sentido emerge da relação entre enunciados postos em um mesmo plano e já podemos identificar diferentes instâncias em que tais enunciados relacionam-se. Portanto, a relação dialógica dos enunciados da FSP é, provavelmente, diferente dos enunciados colocados em relação dialógica na FO. 


\section{CAPÍTULO 2. \\ O IMPRESSO E O DIGITAL: \\ UM ESTUDO SOBRE MEIO, SUPORTE E ESFERA}

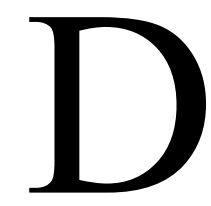

e acordo com o que estabelecemos anteriormente, defendemos a tese de que a hipertextualidade é vista como uma modalidade de relação dialógica que ocorre quando há um movimento remissivo que articula um enunciado-fonte a outro enunciado, cuja ocorrência dá-se também em enunciados impressos. Mesmo antes da ascensão da rede mundial de computadores, os sumários, índices, notas de rodapés e qualquer outro mecanismo de remissão em documentos impressos, evidenciavam a presença do que Ted Nelson denominou hipertexto na década de 1970.

Certamente, o hipertexto conhecido antes do advento da rede mundial possuía características diferentes, não contando com a velocidade no acesso às informações, instantaneidade, a interatividade, a acessibilidade ilimitada e outras características geradas pela tecnologia digital. Com o aparecimento da internet, os mecanismos de remissão que outrora eram operados manualmente pelos leitores no meio impresso passaram a ser articulados com base na tecnologia digital. Por um lado, tais características potencializaram a remissão hipertextual entre os enunciados digitais. Por outro, enunciados impressos, sobretudo os das esferas jornalística e educacional, sofreram mudanças de ordem estilístico-composicionais importantes, por exemplo, a apresentação mais fragmentada da página de um jornal impresso e o desenvolvimento de elementos infográficos incorporados aos enunciados.

A influência da nova tecnologia não afetou exclusivamente os processos de produção, circulação e recepção dos enunciados impressos. Em sua tese de livre-docência, Machado (2011) discorre sobre como a computação gráfica empregada na elaboração de vinhetas televisivas favoreceu o grafismo cinético, ou seja, "novas formas de realizar ideias gráficas” (p. 227), por meio de diferentes sistemas semióticos capazes de conjugar som, imagem e movimento. A transposição da tecnologia digital ao meio televisivo, segundo a autora, favoreceu a introdução dos infográficos em publicações impressas e, então, as próprias limitações do meio motivaram novas maneiras de concretização dos enunciados: 
A página dimensional do meio impresso tornou-se um desafio para o exercício desta linguagem que combina formas gráficas e movimentos. Contudo, não foi impedimento para que as revistas científicas reproduzissem sistemas semióticos da ciência por meio de um grafismo cinético. O exemplo sempre lembrado é o próprio código da molécula de DNA, jamais representado como imagem destituída de movimento. (Machado, 2011, p. 228).

Direta ou indiretamente, a tecnologia digital trouxe modificações importantes para a constituição dos enunciados impressos. Lembramos que os enunciados digitais também foram produzidos incialmente com base nos gêneros discursivos já consolidados em meio impresso. Portanto, o enriquecimento e a complexidade da formação da cultura digital e a transformação de características de enunciados impressos foram aspectos motivadores para uma reflexão sobre o meio ao qual pertencem.

O próprio estado da arte dos estudos midiáticos do hipertexto foi um aspecto central para o capítulo. A literatura demonstra vasta divergência conceitual em relação à definição de internet, descrita alternadamente como tecnologia, meio, ferramenta, espaço e “ciberespaço" (Lévy, 1999). A multiplicidade de noções mobilizadas para descrever a rede mundial de computadores leva-nos a pensar sobre o modo mais adequado de defini-la de acordo com os propósitos da tese, uma vez que nosso corpus é formado por reportagens provenientes dos meios impresso e digital.

A respeito da criação e desenvolvimento da internet, ponto de partida para nossa reflexão, Manuel Castells (1999, p. 82) afirma que tais processos:

(..) nas três últimas décadas do século XX foram consequência de uma fusão singular de estratégia militar, grande cooperação científica, iniciativa tecnológica e inovação contracultural. (Castells, 1999, p.82)

Inicialmente, a internet foi o produto da tentativa de se desenvolver um sistema seguro e eficiente para armazenamento de dados militares, em plena Guerra Fria. Tal como descreve Castells (1999), o sistema idealizado, a ARPANET, visava à descentralização dos dados, que passariam a ser distribuídos em mais de um servidor. Dessa forma, caso sofressem um ataque que comprometesse algum banco de dados, os EUA não teriam as suas informações violadas ou destruídas. 
Em pouco tempo, os pesquisadores das maiores universidades americanas vislumbraram a rede como uma possibilidade para armazenar e intercambiar dados entre seus pares. Em um primeiro momento, os enunciados que transitavam pela internet equivaliam a enunciados impressos digitalizados e fatores como a diagramação e layout foram importados dos enunciados de meio impresso. Com o passar do tempo, houve mudanças na extensão do texto, que passou a ser mais curto, e a incidência de nós remissivos aumentou consideravelmente, sobretudo em gêneros discursivos com traços de maior informatividade, como é o caso das reportagens.

Se antes o impresso influiu diretamente na forma com que os documentos digitais foram dispostos na rede, observamos, atualmente, não só um recuo de tal influência, mas também uma estabilização dos enunciados e gêneros do meio digital. Por exemplo, na pesquisa de mestrado anterior (Machado 2007), constatamos que, com o passar dos anos, o aproveitamento dos nós eletrônicos na revista de divulgação científica Com Ciência sofreu alterações significativas.

Nos primeiros anos de publicação dos enunciados analisados, os nós remissivos eletrônicos eram utilizados em maior quantidade. Nos anos finais de análise, o emprego dos nós não somente diminuiu como foi distribuído de acordo com as coerções dos gêneros ao qual pertenciam. No artigo, cuja presença do autor era mais evidenciada, ocorria menor emprego do link eletrônico. Já na reportagem, com o objetivo de imprimir maior imparcialidade e informatividade ao enunciado, recorria-se ao link com mais frequência.

Certamente, o uso recente da internet na sociedade ainda limita o olhar analítico dos estudiosos para o enunciado digital como objeto. Mesmo assim, a relação impresso / digital já nos traz indícios da influência de um sobre o outro de maneira bilateral. Ao analisar o dialogismo em reportagens da revista de divulgação científica Superinteressante, em sua versão impressa, Macedo \& Grillo (2010) concluem que a forma composicional das reportagens distancia-se, cada vez mais, do modelo de reportagem jornalística tradicional.

As autoras relatam que as reportagens mais recentes apresentam uma composição de ordem hipertextual e possibilitam leituras em que o leitor assume uma posição mais participativa. "Cabe ressaltar que alguns desses recursos já se mostravam de forma embrionária nas reportagens mais antigas, mas foram utilizados com maior desenvoltura após a grande disseminação da internet." (Macedo \& Grillo, 2010, p. 34).

A evolução e a interação entre os meios de comunicação é alvo de reflexão de estudiosos de diversas áreas. O historiador Roger Chartier recentemente discorreu a respeito da influência da digitalidade nos processos de leitura e escrita, afirmando que "a 
textualidade eletrônica de fato transforma a maneira de organizar as argumentações, históricas ou não, e os critérios que podem mobilizar um leitor para aceitá-las ou rejeitálas." (Chartier, 2009, p. 59). Em recente entrevista concedida ao Prof. Dr. Antonio Carlos Xavier (ainda no prelo), Chartier lembra-nos de que a cultura digital é, acima de tudo, uma cultura escrita. O historiador leva-nos a compreender que a relação entre os meios impresso e digital é reciprocamente transformadora. Ao passo em que a digitalidade modifica modos de produção, circulação e recepção dos enunciados, também ocorre uma incorporação de estratégias atribuídas à escrita em meio impresso.

Atualmente observamos uma explosão da documentalidade, levando milhares de pessoas que anteriormente partilhavam da cultura escrita somente em certas esferas da atividade humana, como a escolar ou de sua atuação de trabalho, a escreverem cada vez mais, inclusive em seus momentos de lazer em que a esfera da ideologia do cotidiano é predominante. Talvez o uso cada vez mais frequente de termos que emergem dessa esfera em reportagens de divulgação científica não seja aleatório, como observamos posteriormente nas análises. A escrita tem sido potencializada por meio da portabilidade da internet, armazenada por suportes variados tal como o telefone móvel, os tablets $^{30}$ e o computador, a ponto de um usuário poder relatar desde atividades corriqueiras a eventos de importância mundial em tempo real.

Analisando a história da leitura, o autor aponta para o fato de que a ordem das práticas costuma ser mais lenta em relação aos avanços tecnológicos: “A invenção da imprensa não produziu imediatamente novas maneiras de ler” (Chartier, 2009, p.63). Contudo, o autor reconhece que a tecnologia digital tem modificado as práticas de forma visivelmente mais rápida. Os critérios que levam a tais mudanças, como a reorganização dos enunciados e as novas relações de seleção, aceitação ou rejeição dos enunciados pelos leitores, são motivados pelas próprias características advindas da tecnologia digital, como a possibilidade de maior acessibilidade e interação dos usuários leitores. Segundo exemplo do autor, a relação de confiança estabelecida entre um historiador e seu leitor por meio de um livro de história impresso em uma época em que não se podia obter acesso às mesmas fontes do primeiro diferencia-se das relações de confiança propiciadas pela tecnologia que permite a busca pela fonte e maior autonomia do leitor para construir suas próprias reflexões. Contudo, não podemos ignorar o fato de que o compartilhamento ilimitado tem

\footnotetext{
${ }^{30}$ Dispositivo de tela sensível ao toque para acesso à internet e à aplicativos de entretenimento, cujo formato assemelha-se a uma prancheta.
} 
propiciado um aumento excessivo em casos de plágio ou falta de referenciação dos autores em diversas esferas da atividade humana.

Levando em consideração o fato de que o corpus a ser analisado é constituído de enunciados impressos e digitais, a proposta deste capítulo é a de refletir acerca da relação entre os meios. Nosso objetivo principal é definir as noções de meio, suporte e esfera, conceitos que permearão a metodologia da pesquisa e a análise do corpus posteriormente. O percurso teórico que seguimos possui como ponto de partida as ideias principais de Marshall McLuhan (2007), dentre elas, a de que os meios de comunicação são as próprias extensões do corpo humano. Em seguida, delineamos os conceitos-chave da proposta de Régis Debray para a Midiologia como uma Ciência Humana e seus contrapontos com o pensamento de McLuhan. Abordamos, ainda, a perspectiva histórica da evolução do impresso e seus gêneros segundo Roger Chartier (1999, 2001 e 2009) e Mckenzie (2002).

Especificamente no que tange à passagem do meio impresso ao digital, privilegiamos os conceitos de virtualização e ciberespaço, de acordo com Pierre Lévy (1996 e 1999), que não somente nos ajudam a elaborar uma definição mais precisa de meio e suporte, mas também focam aspectos da internet. Finalmente, após percorrer os conceitos teóricos supracitados, temos o intuito de apresentar uma proposta que considera a internet como um conjunto de esferas da atividade humana, com base na teoria dialógica do Círculo de Bakhtin. Dessa forma, pretendemos verificar a relação estabelecida entre os meios, os suportes e as esferas pelas quais transitam os enunciados analisados.

\subsection{O meio como extensão do homem segundo Marshall McLuhan}

Para dar início à discussão que nos levará a refletir acerca do estatuto da internet e a sua relação com o impresso, partimos da noção de meio delineada por Marshall McLuhan no final da década de 1970. A ideia central exposta pelo autor é a de que os meios de comunicação são extensões do corpo humano. De acordo com o autor, os meios tecnológicos podem ser comparáveis a recursos naturais ou matérias-primas, tal como o algodão ou o carvão e tornam-se "tributos fixos para a inteira vida psíquica da comunidade (...)" de forma que "cada produto que molda uma sociedade acaba por transpirar em todos e por todos os seus sentidos", (McLuhan, 2007, p.37).

Outros três aspectos estão relacionados à hipótese central formulada pelo autor na obra "Os meios de comunicação como extensões do homem” (2007). O primeiro deles, estritamente relacionado à ideia de que o meio é uma extensão do corpo humano, é a noção 
de autoamputação. Trata-se da própria dinâmica estabelecida entre corpo e meio no processo de desdobramento de um em outro. Em seguida, o autor elabora a máxima "meio é mensagem", ou seja, o modo como a informação é transmitida confunde-se com a própria informação. Finalmente, McLuhan discorre sobre o que chama de meios quentes e frios e a relação que estabelecem entre si.

Antes de explorar cada um dos itens acima, torna-se importante esclarecer alguns pontos relacionados às denominações empregadas pelo autor ao longo da obra. Em primeiro lugar, observamos a alternância no uso das expressões "meios de comunicação" e "meios de transmissão". Outro fator relevante é a não distinção entre os termos "meio" e “veículo". Pelo contrário, estabelece-se uma equivalência que pode ser vista por intermédio do uso alternado dos termos em alguns momentos, como nos mostram os seguintes fragmentos:

Este fato, característico de todos os veículos, significa que o "conteúdo" de qualquer meio ou veículo é sempre um outro meio ou veículo. (McLuhan, 2007, p. 22) [Grifos meus]

As mais recentes abordagens ao estudo dos meios levam em conta não apenas o “conteúdo", mas o próprio meio e a matriz cultural em que o meio ou veículo específico atua. (McLuhan, 2007, p. 25) [Grifos meus]

Expostas essas oscilações terminológicas, voltemos à hipótese central da obra de McLuhan que diz respeito ao meio de transmissão / comunicação como uma forma de desdobramento do corpo humano. De acordo com o autor, a relação entre os meios de comunicação como próprias extensões dos sentidos humanos é capaz de provocar consequências psíquicas e sociais que logo alteram os limites e padrões da cultura. Como exemplo, cita o advento da eletricidade como responsável pela rápida disseminação da simulação tecnológica da consciência, o que fez com que o processo criativo do conhecimento se estendesse "coletiva e corporativamente a toda a sociedade humana, tal como já se fez com os nossos sentidos e nervos através dos diversos meios e veículos" (McLuhan, 2007, p.17).

$\mathrm{O}$ autor ainda atribui à eletricidade uma maior sofisticação do sistema nervoso central, o que possibilitou que o homem prolongasse ou projetasse ao exterior o que McLuhan denomina um modelo vivo do próprio sistema. A utilização de um novo meio 
implica uma nova regulação do modo com que o corpo percebe e apreende as novas tecnologias, como aponta o autor:

\begin{abstract}
Contemplar, utilizar ou perceber uma extensão de nós mesmos sob forma tecnológica implica necessariamente adotá-la. Ouvir rádio ou ler uma página impressa é aceitar essas extensões de nós mesmos e sofrer o "fechamento" ou o deslocamento da percepção, que automaticamente segue. (McLuhan, 2007, p.64)
\end{abstract}

Ao discorrer sobre o prolongamento do corpo em meio de transmissão, McLuhan aponta para o processo de autoamputação, outra noção-chave de sua obra. A autoamputação funciona como "alívio imediato para a pressão exercida sobre o sistema nervoso central que se aplica à origem dos meios de comunicação, desde a fala até o computador" (McLuhan, 2007, p.61). Tal processo está estritamente relacionado com os aspectos físicos e físiológicos próprios do desdobramento. De acordo com os mais variados estímulos físicos, o sistema nervoso irá reagir projetando-se "numa estratégia de amputação ou isolamento do órgão, sentido ou função atingida." (McLuhan, 2007, p.60).

Um exemplo dado pelo autor sobre o modo como o processo de autoamputação ocorre é a relação estabelecida entre a roda e os pés, em que a primeira estende-se à segunda ${ }^{31}$. A evolução do uso da roda que resultou "da aceleração das trocas por meios escritos e monetários criou as condições para a extensão ou 'amputação' daquela função corporal.” (McLuhan, 2007, p.60). Ao mesmo tempo, a roda passou a apresentar uma função isolada e mais intensa que, segundo McLuhan, equivale ao pé em rotação.

O conceito de desdobramento do corpo em meio e o princípio da autoamputação colaboram para a formação de um posicionamento teórico em nossa pesquisa, sobretudo no tocante ao modo com que o homem se relaciona com os diferentes meios, suportes e tecnologias que lhe são apresentados ao longo do tempo. Concordamos com o fato de que o advento de uma nova tecnologia ou suporte complexifica as relações de produção e recepção da informação e modifica os meios já existentes por intermédio da regulação, tal como propõe McLuhan.

$\mathrm{O}$ indivíduo também é levado a uma adaptação às novas formas de comunicar e cada tecnologia exige que o corpo se comporte de determinada maneira. A leitura de um documento impresso é menos cansativa aos olhos do que a leitura de um documento digitalizado, por exemplo. Assim como o manuseio do computador difere daquele

\footnotetext{
${ }^{31}$ Este e outros exemplos parecidos serão refutados por Pierre Lévy, como veremos adiante. Por enquanto, é prioritário compreender de que maneira o prolongamento do corpo em meio se faz possível em McLuhan.
} 
dispensado a um jornal, livro ou revista. Atualmente, observamos um investimento da indústria da tecnologia digital em suportes que causem menor fadiga ao indivíduo, tanto no tocante à leitura, quanto ao manuseio de documentos. Este é mais um indício de que os meios, suportes e tecnologias interferem em aspectos físicos que resultam de sua relação com o indivíduo.

Apesar de reconhecermos que o corpo estabelece relações com o meio, discordamos da proposta de McLuhan de que o meio seja uma extensão humana. Primeiro, devemos distinguir o meio de comunicação do suporte que o sustenta. Entendemos o meio como um conjunto de fatores que favorecem o processo de comunicação verbal e não-verbal gerado pela tecnologia e motivado pela esfera da cultura, ou seja, o meio é dotado de suporte físico, mas também se constitui espaço em que a materialidade linguística será concretizada quando transformada em enunciado nas esferas da atividade humana. Quando McLuhan diz que o corpo desdobra-se em meio, parece-nos que o autor refere-se somente ao suporte utilizado.

A ideia de prolongamento pressupõe um continuum entre corpo e meio, ou mesmo entre corpo e suporte, e faz-nos pensar na dificuldade em se estabelecer um limite entre eles. Para que tal afirmação fosse mais consistente, McLuhan teria que fundamentar a própria noção de homem com que opera, homem esse capaz de fundir-se com os meios e ou suportes que o rodeiam. O autor refere-se ao corpo físico do homem e não ao homem enquanto um ser refletido e refratado no signo ideológico. Sob a luz da proposta bakhtiniana, questionamo-nos acerca da proposta de McLuhan, pois o homem, além de ter um corpo físico, é também um ser socializado que fala de uma posição ideologicamente situada nas esferas da atividade humana. Portanto, a relação do homem com o meio também é social.

Além dos princípios de desdobramento e autoamputação supracitados, o autor discorre ainda sobre uma faceta particular da sua definição de meio. Trata-se da máxima "o meio é mensagem". O autor conceitua o meio como a própria mensagem, na medida em que "a tecnologia cria um ambiente humano totalmente novo." (p.10) e isto faz com que o efeito do meio se torne mais forte e intenso. O exemplo citado pelo autor diz respeito ao cubismo como forma de prolongamento do meio em mensagem pela exploração de planos contraditórios, conflito de estruturas, cores e texturas que, por si só, transmitem a mensagem. 
O conceito de meio como mensagem é outro fator que problematizamos. De acordo com o que afirma o autor, se o meio é a própria mensagem e, ao mesmo tempo, desdobramento do corpo humano, qual seria a relação entre corpo e mensagem?

Tal questão não é desenvolvida claramente por McLuhan que passa a refletir sobre uma possível classificação dos meios em um continuum que varia do quente ao frio. Quanto mais quente o meio, maior o prolongamento dos sentidos proporcionado e mais alta é a saturação de dados. O meio considerado quente "não deixa muita coisa a ser preenchida ou completada pela audiência" (McLuhan, 2007, p.38). Por outro lado, o meio de caráter frio é de baixa definição, sendo que "uma magra quantidade de informação é fornecida" (McLuhan, 2007, p.38). Cada meio possui efeitos sobre os seus usuários de acordo com a intervenção de novas tecnologias.

A escrita, por exemplo, tornou-se um meio quente a partir da intensificação da imprensa, uma vez que permitiu maior participação dos sujeitos. O papel é um meio quente "que serve para unificar os espaços horizontalmente, seja nos impérios do entretenimento, seja nos impérios políticos” (McLuhan, 2007, p.39). No caso da imprensa, o autor atenta para o fato de que, com o seu surgimento, formas anteriores foram excluídas da vida e da arte, na medida em que novas formas emergiram e ganharam intensidade.

Podemos comparar o aquecimento do meio a partir do impacto da criação da imprensa com o surgimento da internet. Tanto o grau de interatividade entre usuários quanto o aquecimento ocorrido com a participação do leitor no processo de coautoria dos textos em seu percurso de leitura são indícios de que se trata de um meio quente. Seguindo fielmente a proposta de McLuhan, a internet seria um meio quente, cuja intensidade, ou alta definição, vem produzindo a fragmentação ou especialização das formas e, tomando a perspectiva bakhtiniana, tornando as esferas da atividade humana mais complexas.

A utilização dos meios também pode ocorrer em uma cultura considerada quente ou fria, segundo McLuhan. Os meios quente e frio podem gerar diferentes efeitos ao se chocarem com determinada cultura. No contexto do mundo iletrado, por exemplo, a manifestação de um meio quente como o rádio pode gerar um efeito violento em uma cultura fria. Em contrapartida, o rádio é considerado divertimento para culturas que o autor considera quentes como a inglesa e a americana.

Para exemplificar a diferença entre a ocorrência de determinado meio em culturas distintas, o autor também cita o paradoxo da "bomba quente em plena guerra fria" (McLuhan, 2007, p.47). Nesse exemplo, o choque ocorre entre uma propriedade da bomba 
- ser quente, gerar explosões, fogo - e o caráter de uma guerra cujas armas e o próprio embate eram frios.

A respeito da tecnologia elétrica, que denominamos atualmente digital, McLuhan acrescenta que se trata de um meio total e inclusivo, o que reforça a ideia de que a internet possa ser considerada um meio quente. Por diversas vezes, o autor emprega os termos "elétrica" e "eletricidade" para designar a tecnologia computacional que já vigorava na época, como no fragmento a seguir: "Mas na era da eletricidade, quando o nosso sistema nervoso central é tecnologicamente projetado para envolver-nos na Humanidade inteira, incorporando-a em nós, temos necessariamente de envolver-nos, em profundidade, em cada uma de nossas ações" (McLuhan, 2007, p.18).

A internet resultou tanto da criação da tecnologia digital de armazenamento de dados como da relação entre diferentes meios pré-existentes. Os desdobramentos de sentido decorrentes estabeleceram novos índices relacionais alterando a percepção do homem. Da mesma forma, o rádio já havia alterado "a forma das estórias noticiosas bem como a imagem fílmica, com o advento do sonoro", assim como a televisão provocava "mudanças drásticas na programação do rádio e na forma das radionovelas” (McLuhan, 2007, p.72).

Mesmo tendo sido publicada pela primeira vez no ano de 1969, época em que a ARPANET ainda era o embrião da rede, Mcluhan já discorria sobre a era eletrônica descrevendo o advento de um ambiente totalmente novo. Naquele momento, o autor preconizava o conceito de inteligência coletiva, que atualmente é desenvolvido pelo filósofo Pierre Lévy, ao afirmar que

\footnotetext{
estamos nos aproximando rapidamente da fase final das extensões do homem: a simulação tecnológica da consciência, pela qual o processo criativo do conhecimento se estenderá coletiva e corporativamente a toda a sociedade humana, tal como já se fez os nossos sentidos e nervos através dos diversos meios e veículos. (McLuhan, 2007, p. 17)
}

McLuhan considera que a proliferação de novas tecnologias cria ambientes que logo corrompem, segundo seu próprio termo, o homem e o tornam parte deles. Uma vez estando envolvido com o novo ambiente, o sujeito rapidamente passa a assumir a tecnologia como a própria extensão de seu corpo físico, ou como desdobramento de seu sistema nervoso central, conforme especifica o autor.

Entretanto, mesmo compartilhando a noção de inteligência coletiva, a ideia de que os meios sejam extensões de nós mesmos é criticada por Lévy (1996). Segundo o filósofo, 
mais do que uma extensão do corpo ou uma ferramenta, os meios constituem uma virtualização da ação. Como exemplo, cita que a roda pode até dar a ilusão de um prolongamento das pernas e dos pés, mas, na verdade, ela virtualiza o andar. A noção de virtualização será desenvolvida mais detalhadamente ao longo do capítulo.

O fato de termos selecionado as noções centrais de McLuhan como ponto inicial da reflexão proposta neste capítulo não foi aleatório. Trata-se de uma obra que conseguiu compreender a dinâmica de uso dos meios de comunicação no momento de sua publicação, meados da década de 1960 em que vigorava a Guerra Fria, e que também foi capaz de prever algo muito próximo da tecnologia digital que conhecemos atualmente. Além disso, a obra possui aspectos ainda atuais para a discussão no campo dos estudos midiáticos e por isso é retomada por outros pensadores como Lévy $(1996,1999)$ e Debray $(1993,1994$ e 2000).

Mesmo refutando o pensamento de que "meio é mensagem" ou de que o meio seja uma "extensão do homem", tais estudiosos serviram-se da obra de McLuhan para desenvolver novas propostas. Lévy apresenta a virtualização como contra argumento à afirmação de que o meio é um desdobramento do homem. Mais adiante, também veremos que Debray considera que a teoria de McLuhan constitui o "andar térreo" no campo dos estudos sobre mídia e que, apesar de considerar suas noções um tanto superficiais, concorda que são base para novas propostas.

Para o âmbito de nossa pesquisa, a obra de McLuhan também nos serve como ponto de partida, sobretudo no que diz respeito às definições de meio e suporte que pretendemos estabelecer. Com base nas definições do autor, consideramos que o meio não se confunde com a tecnologia que o sustenta. A tecnologia, por sua vez, está relacionada ao suporte e às ferramentas que propiciam o desenvolvimento e a sofisticação dos meios e sua relação com outros meios. Através da teorização de McLuhan, conseguimos compreender que o computador é apenas um suporte que não corresponde ao meio digital. No entanto, os conceitos do autor não nos levam a uma definição satisfatória a respeito do meio, por isso buscamos respostas em autores como Debray e Lévy para justificar o uso de tal noção para os propósitos da pesquisa. 


\subsection{A midiologia proposta por Régis Debray}

Tendo refletido sobre os pontos principais da obra de McLuhan no que tange aos meios de transmissão e sua relação com o homem, passaremos a discutir as definições de Debray (1993, 1994 e 2000) enredadas em sua teoria midiológica. Seguiremos com a análise de Maingueneau (2005), a fim de verificar as possíveis pontes estabelecidas entre o meio e o discurso.

Debray dedica-se ao exame do que denomina uma nova área no âmbito das Ciências Humanas, a midiologia. Ao longo de três obras sobre o tema (Debray, 1993, 1994 e 2000), o autor procura justificar a existência da midiologia como ciência, delimitando e descrevendo seu objeto, o mídium, e estabelecendo o papel investigativo do midiólogo em relação a esse objeto.

A midiologia é primeiramente proposta por Debray na obra Curso de midiologia geral, originalmente publicada em francês no ano de 1985 e traduzida para o português no ano seguinte. A questão central do autor nessa obra é verificar como os diferentes domínios de atividade se relacionam entre si em veículos ou dispositivos veiculares, que lhe servem de suporte. As perguntas suscitadas por Debray são:

De que maneira isso se transmite, difunde, circula, propaga, multiplica, etc.? Sobre que tipo de suporte? Que é que isso modifica e recompõe no corpo dos transmissores e receptores? Através de que vetores? Que tipo de percursos, redes, alianças, confluências, saídas etc.? (Debray, 1994, p. 36)

Nessa obra considerada inaugural, o autor delineia a midiologia como o conjunto material dos meios simbólicos de transmissão e circulação, tanto sob o ponto de vista técnico quanto social. Segundo Debray, tal conjunto

precede e supera a esfera dos meios de comunicação de massa contemporâneos, impressos e eletrônicos, entendidos como meios de difusão maciça (imprensa, rádio, televisão, cinema, publicidade, etc.). Meios de informação ainda unilateral, chamados sem razão de "comunicação". (Debray, 1994, p.15)

A midiologia, portanto, poderia ser descrita tanto como um espaço quanto uma alternativa para a difusão do conhecimento e da informação constituída por suportes, relações e meios de transporte que determinam a existência social no tempo. $\mathrm{O}$ autor 
prefere empregar o termo transmissão ao invés de comunicação, para que não se confunda com a comunicação face a face entre os indivíduos ao falar da comunicação midiatizada que opera por revezamentos, por meio de mensagens transportadas à distância. No tocante à transmissão, cada veículo utiliza técnicas diferentes: “A eletrônica, por exemplo, serve tanto para o tratamento da informação, como para o transporte do sinal." (Debray, 1994, p. 19). A transmissão está ligada de forma intrínseca às técnicas de difusão por não serem delimitáveis em relação às técnicas de coleta de dados ou registro.

Em Introduction à la médiologie (2000), o autor discorre mais detidamente sobre a diferença entre comunicação e transmissão, afirmando que a midiologia almeja focar a forma com que o homem transmite, mais do que comunica. A transmissão diz respeito a tudo que se refere à dinâmica da memória coletiva e pressupõe um suporte capaz de promover uma performance técnica, ao passo em que a comunicação refere-se à circulação das mensagens em um dado momento e prevê um emissor e um receptor. Apesar de diferentes, os dois processos são complementares e, ao mesmo tempo, indissociáveis, conforme podemos observar por meio da seguinte afirmação:

Comunicação e transmissão não se justapõem, mas sim, são coordenadas. A primeira é a condição necessária, mas não suficiente, da segunda. Pode-se então considerar os estudos de comunicação como um país já bem explorado a ser inserido em um continente mais ou menos delimitado mas cujas dimensões são já imaginadas. (Debray, 2000, p.14)

A transmissão de uma mensagem pode ser entendida em quatro sentidos que não se contradizem ou se confundem. O primeiro deles equivale a um procedimento geral de simbolização, tal como fala, escrita, imagem analógica, cálculo digital. O segundo compreenderia um código social de comunicação, a própria língua natural pela qual a mensagem verbal é pronunciada. Outro sentido poderia ser representado pelo suporte material de inscrição e de estocagem, a saber, a argila, o papiro, o papel, o cartão magnético, a tela. Finalmente, o autor cita a presença de um quarto sentido que pressupõe um dispositivo de registro, podendo ser manuscrito, impresso, eletrônico, etc.

\footnotetext{
${ }^{32}$ Communication et transmission ne sont pas des registres à juxtaposer mais à coordonner. (...). La première est la condition nécessaire, mas non suffisante, de la seconde. On peut donc considérer les études de communication comme un pays déjà bien exploré à réinsérer dans un continent peu ou mal repéré mais dont on devine déjà les dimensions, (DEBRAY, 2000, p. 14).
} 
A tese de Debray (1994, p. 151) é marcada pelo exame do que o autor denomina de "aventura da mensagem cristã" em que a função comunitária das comunicações é fundadora da midiologia. O autor demonstra como a mensagem cristã difundiu-se e consolidou-se historicamente a partir do discurso de um homem simples, Jesus Cristo, para pessoas também simples, sem qualquer acesso às tecnologias mais avançadas de suporte de sua época. Isto só foi possível, porque a tradição oral que perdurou ao longo dos anos iniciais após a morte de Cristo também pode ser considerada um meio de transmissão, muito eficaz, inclusive, naquele contexto. Cristo comunicou e a Igreja transmitiu.

Ao longo dos anos, as novas técnicas e tecnologias levam ao desenvolvimento de novos suportes e meios de transmissão. O autor relata inúmeros casos de como os suportes se relacionam com os meios receptores e transmissores. Recorreremos ao exemplo da criação da imprensa a partir da impressão da primeira Bíblia, em 1448, feita por Gutenberg, quando a evolução dos suportes suscitou novas maneiras de produzir conhecimento e difundir as informações de toda uma época: "A utilização maciça do suporte papel supera a barreira animal e libera a produção de pensamento dos ciclos curtos da reprodução do ser vivo.” (Debray, 1994, p.212).

O mesmo processo ainda possibilitou a desnaturalização do suporte, a multiplicação das mensagens e a aceleração da história no século XVI. Além de acelerador, o papel funcionou como redistribuidor de excedentes financeiros segundo Debray (1994, p. 212): "Desencadeia a primeira industrialização da memória e, pelo viés de um consumo de massa do suporte escrito, a entrada da troca simbólica no plano comercial."

A partir dessa tese central, Debray delimita o objeto de análise da midiologia, o mídium, diferenciando-o das noções de meio, segundo McLuhan, e suporte. No glossário publicado em Manifestes mediologiques (Debray, 1994, p.24), o autor elucida que o mídium é um sistema dispositivo-suporte-procedimento ${ }^{33}$. Isto é, o mídium equivale a um conjunto de fatores, em que o suporte configura-se como elemento constitutivo. O suporte é descrito como uma superfície de inscrição de traços enquanto o mídium pode designar um procedimento geral de simbolização (fala articulada); um código social de comunicação (a língua utilizada entre um locutor e escritor) ou um suporte físico de inscrição e estocagem.

Considerando o suporte como parte do mídium, bem como a relação de complementaridade entre os dois fatores, Debray (1994) discorre a respeito do evolucionismo midiológico. No que tange ao suporte, o autor nos mostra que a influência

\footnotetext{
${ }^{33}$ Système dispositif-support-procédé, (DEBRAY, 1994, p.24).
} 
de um em outro passa despercebida. Assim, temos a imprensa como espelho da caligrafia; a fotografia imitando, inicialmente, a pintura; o cinema tomando como modelo o teatro. De acordo com o autor, "cada nova geração imita a anterior. Não se trata de recusar a evolução, mas antes do alinhamento do recém-nascido ao antepassado.” (1994, p.214).

Cremos que o mesmo tenha ocorrido com os suportes da tecnologia digital. No entanto, a diferença é que digitalidade que suporta a grande rede permite uma difusão maior em tempo menor. Isto é, com pouco mais de 10 anos de uso comercial, já podemos reconhecer os seus produtos e apontar aspectos dessa revolução midiológica. Certamente, daqui a algum tempo, teremos mais elementos para caracterizar as relações entre o suporte e as tecnologias digitais sustentadas por ele.

A difusão cada vez mais ampla e veloz suscita uma crítica do autor quanto à fragilidade e efemerização do suporte. Debray (1994) aponta a perenidade do papiro perante a argila e do papel em relação ao pergaminho. Segundo ele,

a indústria é um acelerador de obsolência e a cultura uma salvaguarda de permanência. É um dos paradoxos da noção de indústria cultural. A indústria destrói o que a cultura deve estocar. A primeira só pode viver fabricando o que é perecível e a outra arrancando o tempo que resta ao longo que passa. (Debray, 1994, p.228)

No caso dos suportes digitais, como o computador, por exemplo, esse fato torna-se ainda mais sensível. Outro processo que acompanha o de efemerização dos suportes é o de democratização comunicativa. Um número crescente de indivíduos tem acesso a uma quantidade cada vez maior de informação devido a sua mobilidade. Em oposição a um concerto de ópera, o rádio atinge uma audiência maior. Considerando a velocidade, a democratização da internet não fugirá desta regra, mas será mais rápida do que os demais meios de transmissão.

O autor aponta para um processo específico em que cada novo mídium entra em estado de "curto-circuito" com a classe dos mediadores proveniente do mídium precedente. Debray cita como exemplo o fato de que, com os satélites e agências de imprensa, a televisão "curto-circuitou" e foi permitido aos consumidores satisfazerem diretamente seu apetite por cultura. Consideraremos que o mesmo acontece com o advento da internet que permite a seus usuários satisfazer diretamente seu apetite pela interação no meio digital e pelo acesso à informação. 
O termo "curto-circuitar" é recorrente nas obras do Debray. Em 1994, o autor o descreve como o desmantelamento de um mídium em uma nova categoria de mediadores no interior de um mídium precedente de menor rendimento ${ }^{34}$. Já em 2000, há outros exemplos de emprego do termo, como observamos na passagem em que o autor descreve o impacto que a impressão causara na hierarquia Eclesiástica na Idade Média.

O conjunto dos sistemas ou dos variados mídiuns a que nos referimos previamente forma o que Debray denominará midiasferas. Caracterizadas como um mega sistema de transmissão e transporte, as midiasferas constituem um dos conceitos centrais da análise do autor. Seu papel seria o de organizar um espaço / tempo particular, o cronotopo, caracterizando-se como um regime de velocidades tecnicamente determinado e ao mesmo tempo intelectual e socialmente determinante.

Cada midiasfera é ela própria o encaixamento das esferas precedentes, imbricadas umas nas outras. O resultado são "sistemas instáveis e cada vez mais complexos, à medida que se sobrepõem ou sedimentam em tumultuosas coexistências, as gerações sucessivas de meios de comunicação de massa.” (Debray, 1994, p.266). As midiasferas não se excluem, mas sim mantêm a sua integridade, a sua unidade. Cada uma delas reordena suas diversas redes com o aparecimento de memórias ou dispositivos de armazenamento de dados, cada vez mais eficazes.

Na obra publicada em 1985, o autor descreve a midiasfera por meio de uma metáfora que a aproxima de um ecossistema. Tal ideia é retomada em sua obra de introdução, ao afirmar que:

uma midiasfera não é mais nem menos do que a totalidade de uma bioesfera em um reino vivo. Ela pode abrigar uma multiplicidade de ecossistemas ou de microambientes (como a biosfera uma multiplicidade de biotopos), relativamente autônomos. (Debray, 2000, p. 45) ${ }^{35}$

A relação estabelecida por Debray (1993, 1994 e 2000) entre sujeitos e objetos difere da que vimos em Mcluhan (2007), que articula uma relação de prolongamento entre

\footnotetext{
${ }^{34}$ Court-circuit: << déclassement>> par un nouveau médium de la classe des médiateurs issue d'un médium antérieur, à rendement plus faible, (DEBRAY, 1994, p. 217).

${ }^{35}$ Une mediasphère n'est pas plus ni moins totalitaire qu'une biosphère dans le règne vivant. Elle peut abriter une multitude d'écosystèmes ou de micro milieux culturels (comme la biosphère une multitude de biotopes), relativement autonomes, (DEBRAY, 2000, p. 45).
} 
eles. Ao longo das três obras consultadas, Debray desenvolve a sua crítica de McLuhan afirmando que, para a midiologia, não há a noção instrumental de seus instrumentos que consideraria "a escrita como um sucedâneo da palavra, o telefone como um prolongamento da voz no espaço, a televisão como um telefone ótico (...)” (Debray, 1994, p.79). Nessa perspectiva midiológica, os instrumentos resultam daquilo que fizermos deles. $\mathrm{O}$ fato é que os instrumentos também podem instrumentalizar os sujeitos:

O mais curioso é que essa ilusão de continuidade ou de homogeneidade entre a coisa criada e seu criador é perfeitamente comprovada pela genealogia das ramificações técnicas. No animal, gesto e utensílio se sobrepõem, sem se desgrudar, no órgão físico. No homem, o utensílio prolonga o gesto e se desliga dele. (Debray, 1994, p.80)

De acordo com Debray (1994), o maior problema da teorização de McLuhan (2007) é o fato de o autor não descrever o mídium como objeto ${ }^{36}$, afirmando que "o mídium segundo o sentido McLuhan da palavra não passa de um piso térreo"37 (1994, p. 22). Complementa dissertando que "é num universo, mágico-religioso que meio e mensagem estão em simbiose" (p. 33), como no caso em que a Torá, livro sagrado judaico deve ser tocado com uma luva especial para que as mãos não o toquem.

No tocante à relação entre mídium e discurso, Maingueneau (2005) aponta para a importância tanto do transporte quanto do suporte para o processo de materialização do discurso. Concordando com Debray, ele reconhece que o mídium não se resume a um simples meio de transporte de informação. Ao contrário, deve ser compreendido como um fator que influencia e modifica todo o conjunto de gêneros discursivos que abrange.

\footnotetext{
${ }^{36}$ Antes de prosseguirmos, faz-se necessário um esclarecimento de ordem epistemológica importante. A partir da leitura dos dois autores até o momento, entendemos que a noção de 'meio' apresentada por McLuhan difere do conceito de 'mídium' proposto por Debray. Enquanto para o primeiro o meio de comunicação pode ser considerado um prolongamento do homem, confundindo-se ao mesmo tempo com a própria mensagem, o segundo rebate os dois argumentos, propondo que o meio do qual discorre McLuhan é parte integrante do mídium. Apesar de termos concordado com alguns posicionamentos de Debray, sobretudo na questão do prolongamento, devemos atentar para o fato de que os objetos mobilizados pelos dois autores são distintos. Na verdade, Debray incorpora a noção de meio na complexidade do mídium, mas o contrário não acontece, pois a teoria de McLuhan não discorre sobre o mídium. Parece-nos que, no momento em que Debray critica McLuhan por não tomar o mídium como seu objeto, o midiólogo não distingue meio de mídium, contrariando a sua própria posição epistemológica. Em sua concepção, o meio pode ser parte do mídium, mas nunca o mídium poderá ser reduzido ao meio, da mesma forma em que a parte nunca equivalerá ao todo, por mais que o todo seja constituído pela parte. Portanto, a constatação de que os conceitos de meio e mídium entre os dois autores são distintos auxiliar-nos-á em nossa reflexão final sobre o que é suporte e meio no âmbito de nossa pesquisa.

37 “le médium au sens McLuhan du mot n’est qu'un rez-de-chaussée.”, (DEBRAY, 1994, p. 22).
} 
Segundo o autor, o advento da tecnologia digital propiciou a consciência sobre a relevância do suporte e do mídium, uma vez que sua aparição provocou uma ruptura com a civilização do livro compartilhadora da mesma noção de sentido. Consequentemente, quando se fala em mídium de um gênero discursivo deve-se considerar, além do suporte material em senso strictu, o conjunto de circuitos que organizam a língua/discurso. $\mathrm{O}$ gênero é um dos elementos que fazem parte do dispositivo comunicacional, ao lado do suporte e do modo de difusão, que leva o indivíduo a se comunicar.

O autor exemplifica a relação entre mídium e discurso ao citar o discurso político que, primeiramente, era difundido diretamente para as pessoas em praça pública. Para ser ouvido, o político deveria fazer impor sua voz, assim como seus ideais políticos. Com o aparecimento do rádio, não houve mais a necessidade da imposição pelo grito, uma vez que o mídium propiciava a possibilidade de se falar calmamente, de forma mais dócil. $\mathrm{O}$ advento da televisão transformou ainda mais o discurso político, uma vez que o conteúdo do que é dito é superado pela forma com que é dito e veiculado, a fim de ganhar a simpatia do grande público.

Apesar de não incorporarmos a noção de mídium proposta por Régis Debray, tal como Maingueneau, no âmbito de nossa pesquisa, a teorização de Debray (1993, 1994 e 2000) leva-nos a considerações precisas acerca do que consideraremos meio, bem como auxilia-nos a esboçar uma primeira definição a respeito da internet. Assim como McLuhan (2007), ao afirmar que o suporte não deve se confundir com o meio, Debray também considera tal distinção importante. No entanto, o autor não opõe propriamente o suporte ao meio, mas estabelece uma relação do suporte diretamente com o mídium. Conforme apontamos anteriormente, o suporte material de inscrição e estocagem é parte constituinte do mídium ao lado de outros três fatores: o dispositivo de registro da informação; o procedimento de simbolização que compreenderia a fala, a escrita, a imagem, entre outros aspectos; e o código de comunicação social que seria a própria língua natural.

Com base na teoria de Debray, tanto o jornal impresso quanto o jornal digital podem constituir diferentes mídiuns. O jornal impresso possui a escrita, a diagramação e a imagem como processo de simbolização ao passo em que o jornal digital, assim como a internet, opera com base em múltiplas formas de simbolização, como a fala, a escrita ou a imagem. Como código de comunicação social, ambos partem de uma dada língua natural, a língua portuguesa. No tocante ao suporte material, o jornal impresso vale-se do papel, assim como o jornal digital vale-se de diferentes suportes capazes de processar a tecnologia 
digital, tais como o computador, o telefone celular, os dispositivos de som e vídeo como os i-pods, os livros eletrônicos, entre outros. Finalmente, o próprio dispositivo de registro autodesigna os mídiuns, sendo que um é de natureza impressa e o outro digital.

No âmbito da tese, a noção de meio que empregaremos é mais abrangente do que o 'mídium' de Debray e o próprio 'meio' de McLuhan. O que denominaremos 'meio impresso' não corresponde somente ao jornal impresso, mas a todo o universo dos documentos impressos. Assim como o meio digital será utilizado para se referir aos documentos inscritos na tecnologia e suportes digitais. Logo, assumiremos o impresso e o digital como meios de transmissão e veiculação da comunicação verbal e não-verbal.

\subsection{Algumas considerações sobre o desenvolvimento do impresso}

Considerando o fato de que o corpus de nossa pesquisa é constituído de enunciados digitais e impressos, delineamos alguns pontos relacionados ao advento do impresso sob o ponto de vista de sua incursão histórica. Para realizar tal tarefa, recorreremos ao especialista em crítica textual e bibliografia D. F. Mckenzie e ao historiador Roger Chartier. Ambos os autores debruçaram-se sobre questões acerca do surgimento e desenvolvimento dos suportes referentes ao meio impresso, bem como as relações estabelecidas entre os textos e seus leitores, sob um viés histórico.

Em sua obra Making meaning (2002), Mckenzie dedica um capítulo ao processo de transformação do discurso oral ao manuscrito e do manuscrito ao impresso. Em sua análise, o autor afirma que os textos orais, manuscritos e impressos relacionam-se de forma complementar e não competitiva. Para chegar a tal conclusão, seus estudos contaram com a leitura e análise de aspectos físicos dos livros do século XVII. A relação complementar entre os meios é destacada, segundo o autor, pelo fato de que não deixamos de falar quando aprendemos a escrever, nem de escrever quando começamos a imprimir.

Apesar da relação de complementaridade observada entre os textos na história da evolução dos meios e suportes, Mckenzie (2002) considera que cada suporte causa impacto sobre os textos em circulação e, consequentemente, nas formas de leitura e captação dos mesmos. Como exemplo, o autor afirma que o impresso deslocou a escrita como uma forma de "record", ou seja, como forma de gravação ou estocagem das informações.

$\mathrm{O}$ autor destaca o oral como presença e evidência em um primeiro momento. Os acordos e as leis eram estabelecidos via meio oral. Já a respeito do manuscrito, o mais importante para o leitor era "o senso de privilégio de estar perto do autor, em ser um de 
uma comunidade mais seleta do que a leitura amorfa da impressão" ${ }^{38}$, (p.248). Em relação ao impresso, Mckenzie ressalta que a impressão como um processo é inferior ao discurso oral em termos de dinâmica espacial entre orador e audiência. As pausas entre as palavras impressas não equivalem às pausas do texto oral. No entanto, a organização espacial do meio impresso é que possibilita a multiplicação das cópias, da portabilidade e da permanência dos textos.

O historiador Roger Chartier, cuja obra é voltada para a história do livro, dos textos e da cultura escrita, retoma o pensamento de Mckenzie, no que tange à evolução dos meios, de que "novos leitores fazem novos textos, e suas significações são uma função de suas novas formas" (1999, p. 126). O historiador, no entanto, aprofunda-se na relação do leitor com os diferentes meios ressaltando que

\footnotetext{
com a transformação formal e material de sua apresentação, que modifica formato e paginação, corte do texto e ilustração, os textos podem ganhar novos públicos, mais amplos e menos eruditos, e receber novas significações, distantes das que foram desejadas por seu autor ou construídas por seus primeiros leitores.
}

A força de persuasão de um meio reside na credibilidade que seus leitores / usuários lhe atribuem. Tal afirmação referente à apropriação do suporte e ao desenvolvimento da leitura resulta da análise de Chartier sobre os textos e livros que circulavam na época do Renascimento. Em uma época em que a cultura e condição dos leitores eram bastante variadas, os livros circulavam na totalidade do corpo social. Dessa maneira, os mesmos textos, os mesmos gêneros e suportes, serviam públicos distintos: "é preciso, assim, que voltemos nossa atenção para usos diferenciados dos mesmos gêneros, dos mesmos textos e, às vezes, mesmo que as formas editoriais visem públicos distintos, das mesmas publicações.” (1999, p.122). De acordo com Chartier, para se entender a história da leitura e de seus diferentes leitores, deve-se investigar o processo de apropriação dos textos com um olhar analítico para os seguintes aspectos: "a materialidade dos objetos escritos e os gestos dos sujeitos leitores.” (1999, p.124).

Em sua aula inaugural no Collège de France em outubro de 2007, o historiador define o livro e aponta para a sua dupla natureza, a material e a discursiva. A partir dessa observação, o objetivo do pesquisador é o de "refletir sobre os modos de convocação dos

\footnotetext{
38 "For the reader of manuscripts, that association was less important perhaps than a sense of privilege at being close to the writer, at being one of a more select community than the amorphous readership of print." (Mckenzie, 2002, p. 248).
} 
textos ou sobre a dupla natureza do livro" (2009, p.42) ${ }^{39}$. Além de suporte para determinados enunciados, o livro também pode ser considerado, segundo Chartier, o resultado de múltiplas operações que resultam de técnicas e competências diversas. Podemos estender tal consideração ao jornal que, conforme argumentamos anteriormente, constitui o meio resultante de um conjunto de técnicas e competências e que, na visão de Chartier, é duplamente orientado, tanto material quanto discursivamente. A obra de Chartier é parte importante para pensarmos a relação entre o meio, o suporte e os indivíduos, bem como o desenvolvimento da escrita ao longo do tempo face ao advento das novas tecnologias.

\subsection{A virtualização e o ciberespaço}

Diferentemente das teorizações anteriores, a proposta de Pierre Lévy (1993, 1996, 1999) sobre os meios de comunicação centra-se nas questões pertinentes à tecnologia digital e à internet. Ao buscarmos as definições de Lévy, pudemos notar que o autor emprega o termo suporte digital para referir-se ao computador e meio para designar a internet em um primeiro momento. Enquanto suporte dotado de ferramentas e componentes - o disquete, o disco rígido e o disco ótico, entre outros elementos - o computador, segundo Lévy, “é (...) antes de tudo um operador de potencialização da informação.” (1996, p.41).

Assim como em Mcluhan, o suporte não se confunde com o meio. No entanto, Lévy opera com uma noção advinda do contexto dos estudos das redes digitais, o ciberespaço. Segundo o filósofo, a internet é gerada pelo suporte computacional, mas desdobrada em ciberespaço. Trata-se do espaço digital de troca de informações entre os usuários da rede e as memórias dos seus computadores. No âmbito do ciberespaço, a tecnologia e suporte digitais favoreceram a potencialização do mecanismo de remissão entre os enunciados, fazendo com que as relações dialógicas hipertextuais que analisamos passassem a ser mais evidentes e explícitas.

O ciberespaço possibilita acessibilidade de dados à distância, bem como a transferência rápida de arquivos, do mesmo modo que permite a criação de grupos sociais e, no escopo da linguagem, suscita a criação de novos gêneros discursivos. O ciberespaço é:

\footnotetext{
39 "Réflechir sur les modes d'assignation des textes ou sur la double nature du livre", (Chartier, 2009, p. 42).
} 
o novo meio de comunicação que surge da interconexão mundial dos computadores. O termo especifica não apenas a infraestrutura material da comunicação digital, mas também o universo oceânico de informações que ele abriga, assim como os seres humanos que navegam esse universo. (Lévy, 1999, p. 17)

Ao contrário de Mcluhan, o autor não considera que o desdobramento dos corpos represente uma extensão do próprio corpo humano, mas afirma que os dispositivos virtualizam as ações desse corpo. No plano das percepções, dispositivos tais como o telefone e a televisão virtualizam sentidos como audição e visão, respectivamente. $\mathrm{O}$ autor chega a definir a televisão como o "grande olho coletivo" (p.28).

No plano das projeções, o telefone separa a voz, que o autor delimita como "corpo sonoro", do corpo material e tangível. Neste caso, a internet e o ciberespaço também seriam virtualizações que projetam ações do homem, mas especificamente no espaço digital. Apesar da crítica a Mcluhan quanto à noção de meio como extensão do homem, por considerar que os meios, de fato, virtualizam as ações humanas, o filósofo Pierre Lévy reconhece que os corpos passam por um processo de desdobramento, como nos mostra no fragmento abaixo:

Da socialização das funções somáticas ao autocontrole dos afetos ou do humor pela bioquímica industrial, nossa vida física e psíquica passa cada vez mais por uma "exterioridade" complicada na qual se misturam circuitos econômicos, institucionais e tecnocientíficos. (Lévy, 1996, p.27).

Ao examinar as relações entre texto e hipertexto, o autor discorre sobre a relação entre os meios impresso e digital e afirma que "os dispositivos hipertextuais nas redes digitais desterritorializam o texto" (Lévy, 1996, p.48). Em seguida, o estudioso determina que "é como se a digitalização estabelecesse uma espécie de imenso plano semântico, acessível em todo lugar, e que todos pudessem ajudar a produzir, a dobrar diversamente, a retomar, a modificar, a dobrar de novo (......” (Lévy, 1996, p.49). O próprio autor afirma que: 
a cultura do texto, com o que ela implica de diferido na expressão, de distância crítica na interpretação e de remissões cerradas no interior de um universo semântico de intertextualidade é, ao contrário, levada a um imenso desenvolvimento no novo texto, a virtualização parece fazê-lo coincidir com sua essência subitamente desvelada. Como se a virtualização contemporânea realizasse o devir do texto. (1996, p.50).

A crítica quanto à desterritorialização do texto também pode ser encontrada nas reflexões de Melo (2004). Ao questionar a afirmação de Levy (1999) de que todo o hipertexto possa ser considerado um texto de acessibilidade ilimitada, a autora recorre aos princípios da $\mathrm{AD}$ francesa. Melo concorda com o fato de a internet constituir-se como ciberespaço em que, tecnicamente, há espaço para todos. No entanto, a autora afirma que a democratização dos discursos acontece de forma diferente. Não basta que os textos sejam produzidos e lançados pelos usuários da rede, mas sim, que entrem na "ordem do discurso" (2004, p.137).

Mesmo no ciberespaço, os posicionamentos discursivos de diferentes empresas e órgãos de comunicação estariam preservados e "as ideias não hegemônicas muito dificilmente ganham espaço no jornalismo online" (2004, p.137). Em meio digital, as dinâmicas discursivas são preservadas. Tanto a noção de acessibilidade ilimitada quanto a de desterritorialização do texto não levam em conta o fato de que todo hipertexto é um texto e, segunda a autora, "é produzido com base em determinados interesses e suposições" (2004, p.138).

Ainda na esteira contrária a respeito da desterritorialização do texto, lançamos um questionamento com base na noção de enunciado proposta por Bakhtin. Consideramos que os enunciados que circulam pelo ciberespaço são elaborados e interpretados por diferentes $\operatorname{esferas}^{40}$, inclusive em meio digital. Mcluhan (2007) também reconhece que os meios e seus conteúdos circulam por diferentes matrizes culturais. $\mathrm{O}$ fato de um leitor transitar por uma esfera desconhecida não garante que ele acessará os sentidos estabelecidos pelos seus enunciados e gêneros. Portanto, contestamos a noção de que haja um texto sem fronteiras nítidas, sem interioridade definível.

As próprias características dos enunciados, tal como estilo, conteúdo temático e forma composicional podem ser consideradas fronteiras entre enunciados de diferentes gêneros e esferas, sendo um dos fatores de sua conclusibilidade, e mesmo entre textos. Ao

\footnotetext{
${ }^{40}$ A definição de internet como conjunto de esferas será desenvolvida de forma mais detalhada na próxima seção.
} 
considerar as definições de texto, tal como em Kristeva, a noção de que as relações intertextuais funcionam como um mosaico de textos seria descaracterizada. O mosaico é formado por peças diferentes e apresenta uma coloração diversa, enquanto a definição de Lévy nos leva a pensar num quadro em que as cores pertinentes a cada texto estão esfumaçadas. Consideramos que a própria fragmentação do ciberespaço e de qualquer meio tornam os enunciados discerníveis. Caso não fossem, não conseguiríamos sequer identificar as relações de intertextualidade ou a hipertextualidade presentes.

No âmbito de nossa tese, a leitura de Lévy contribui para a delimitação da noção de suporte, bem como nos apresenta uma nova forma de pensar a internet, como um espaço digital para comunicação em que ocorre a interação verbal e não verbal entre os indivíduos. Mesmo questionando a noção de desterritorialização do texto, nossa proposta acerca da internet agrega a definição de ciberespaço, segundo Lévy, e será apresentada a seguir.

\subsection{A internet como conjunto de esferas da atividade humana}

Com a finalidade de estabelecer uma relação entre o ciberespaço ou meio digital e os enunciados que nele circulam, recorreremos a uma das noções-chave postuladas por Bakhtin e seu Círculo, o conceito de esfera. A noção de campo ${ }^{41}$ ou esfera da atividade humana na teoria dialógica do Círculo foi composta por duas linhas de pensamento. A primeira delas pode ser atribuída a Volóchinov em Marxismo e filosofia da linguagem (2004), publicado originalmente em 1929, que diz respeito aos sistemas ideológicos constituídos e à psicologia do corpo social. A segunda formulação do conceito pode ser encontrada em Bakhtin, no texto de 1952/1953, Os gêneros do discurso que, ao contrário do primeiro autor, não emprega termos marxistas no desenrolar de sua reflexão.

No texto da década de 1920, Volóchinov elaborou uma reflexão sobre as ideologias constituídas por signos afirmando que:

\footnotetext{
${ }^{41}$ Nas traduções e na própria obra de Bakhtin e seu Círculo, alternam-se os termos esfera e campo da atividade humana. No artigo em que propõe uma aproximação de alguns aspectos das obras de Bourdieu e do Círculo de Bakhtin, Grillo (2005) opta pelo emprego do termo 'campo'. Primeiro, por conta da tradução realizada pelo estudioso Paulo Bezerra (2003) da obra Estética da criação verbal. Segundo, pelo fato de esse também ser o termo empregado por Bourdieu.
} 
um produto ideológico faz parte de uma realidade (natural ou social) como todo corpo físico, instrumento de produção ou produto de consumo; mas, ao contrário destes, ele também reflete e refrata uma outra realidade, que lhe é exterior. (Volóchinov ${ }^{42}$ / Bakhtin, 1929/2004, p.31)

Influenciado pela teoria marxista, Volóchinov incorpora à sua reflexão o que considera um dos problemas fundamentais do marxismo, a relação entre infraestrutura e superestrutura. A questão que Volóchinov se coloca é saber de que forma as ideologias são determinadas pela infraestrutura sem recorrer à causalidade mecanicista, uma vez que "toda esfera ideológica se apresenta como um conjunto único e indivisível cujos elementos, sem exceção, reagem a uma transformação da infraestrutura." (Volóchinov/Bakhtin, 1929/2004, p.39). O interesse de Volóchinov é saber de que forma a realidade, ou a infraestrutura, determina o signo ideológico, ou seja, como o signo reflete e refrata a realidade em cada esfera da atividade humana.

O domínio dos signos, ou esfera ideológica, abarca uma série de campos ideológicos - seja científico, religioso, jurídico, entre outros - com orientações específicas que incidem no modo como a realidade é refletida e refratada. Segundo o autor, "cada campo dispõe de sua própria função no conjunto da vida social. É seu caráter semiótico que coloca todos os fenômenos ideológicos sob a mesma definição geral." [grifo do autor] (Volóchinov/Bakhtin, 1929/2004, p.33).

Ao discorrer sobre a ideologia do cotidiano, Volóchinov nos revela um segundo aspecto referente à noção de ideologia do cotidiano que difere dos outros sistemas ideológicos constituídos, como a arte ou a ciência e afirma que, "a ideologia do cotidiano constitui o domínio da palavra interior e exterior desordenada e não fixada num sistema, que acompanha cada um dos nossos atos ou gestos e cada um dos nossos estados de consciência.” (Volóchinov/Bakhtin, 1929/2004, p.118). Como uma matriz, os demais sistemas ideológicos são cristalizados a partir da esfera da ideologia do cotidiano e, ao mesmo tempo, exercem forte influência sobre a esfera matriz.

A partir do pensamento de Volóchinov e seus textos previamente publicados, Bakhtin reflete sobre o conceito de esfera da atividade humana relacionando-o aos gêneros do discurso, no início da década de 1950. De acordo com a visão de Bakhtin, as esferas são definidas como o espaço em que as especificidades dos mais variados enunciados

\footnotetext{
${ }^{42}$ No corpo do texto é possível utilizarmos o nome do autor com acentuação. No entanto, quando acompanha alguma citação a orientação é para que o acento não seja acrescentado, pois não há tradução.
} 
constituem os gêneros do discurso. Em Os gêneros do discurso (1952-53/2003), Bakhtin afirma que as esferas elaboram seus tipos relativamente estáveis de enunciados sendo esses tipos denominados gêneros discursivos. Os gêneros, ao mesmo tempo, constituem as diferentes esferas e são constituídos por elas conforme as suas condições específicas:

A riqueza e diversidade dos gêneros do discurso são infinitas porque são inesgotáveis as possibilidades da multiforme atividade humana e porque em cada campo dessa atividade é integral o repertório de gêneros do discurso, que cresce e se diferencia à medida que se desenvolve e se complexifica um determinado campo. (Bakhtin, 1952-53/2003, p. 262).

Os enunciados emanam das mais variadas esferas, refletindo as condições estabelecidas em cada uma delas, por meio dos gêneros do discurso e seus elementos constituintes, estilo, conteúdo temático e forma composicional. Cada gênero e seus enunciados são gerados a partir de uma determinada função (científica, técnica, entre outras), bem como de determinadas condições de comunicação discursiva, específicas de cada esfera. Logo, os gêneros, caracterizados por determinados tipos de enunciados estilísticos, temáticos e composicionais, transitam por esferas específicas (Bakhtin, 195253/2003, p. 266).

A noção de esfera da atividade humana é imprescindível para a elaboração de uma análise dialógica baseada na observação de relações entre enunciados integrais, especialmente os que são constituídos em meio digital. Por meio da reflexão sobre o modo com que a tecnologia digital e seus suportes, podemos também refletir sobre o processo de transformação da linguagem em outros meios, como o impresso e até mesmo o oral. Para citarmos um exemplo, a organização hiperestrutural, fenômeno que se constituirá uma de nossas categorias de análise, tomou a forma composicional de gêneros como notícia e reportagem no jornal impresso e foi potencializada após o surgimento de versões digitais desse tipo de mídium.

Apoiando-se na noção de esfera da atividade humana proposta pelo Círculo, Araújo (2006) aponta para o processo de complexificação da esfera frente à emergência da nova tecnologia ao propor uma análise detalhada do gênero chat. No âmbito de sua pesquisa, o autor define a internet como uma esfera digital ou eletrônica cujas características principais 
seriam o hipertexto, a hipertextualidade ${ }^{43}$ e a multissemiose. O autor acrescenta de forma mais específica os aspectos inerentes a essa esfera ao afirmar que:

\begin{abstract}
Além dessa reformatação da escrita, é característica dessa esfera de comunicação a arte de combinar outras linguagens, como a imagem e o som, o que propicia a afirmação de que a esfera discursiva digital tem como característica maior uma rica heterogeneidade semiótica. (Araújo, 2006, p. 78)
\end{abstract}

Assim como Araújo (2006) também propomos uma definição sobre a internet levando em conta a noção de esfera da atividade humana elaborada por Bakhtin, na década de 1950 e Volóchinov, nos anos 1920. O fato de o nosso alvo de análise ser formado por enunciados tanto do meio impresso quanto do meio digital faz com que nossa elaboração seja diferente. Por meio de nossas reflexões, consideramos a internet como um ciberespaço de acordo com o que postula Lévy (1999), constituindo-se como um espaço de interação verbal e não verbal que, em toda a sua complexidade, abriga diferentes esferas atendendo a suas diferentes condições de comunicação discursiva.

A seleção de reportagens de divulgação científica veiculadas nos meios impresso e digital serve-nos como fonte de reflexão sobre as esferas jornalística e científica. Os enunciados produzidos nessas esferas em meio digital não escapam às características constitutivas do meio impresso, ou até mesmo televisivo ou radiofônico. Tal fato pode também ser encontrado nas páginas de uma revista ou jornal que apresentam enunciados oriundos de esferas distintas, mas que se refletem e são refratados pelas especificidades da esfera jornalística.

No entanto, a internet revela uma capacidade mais latente em conglomerar diferentes esferas e seus enunciados do que outros meios. A capacidade de aglomeração de diferentes esferas resulta da própria constituição heterogênea do meio internet que possibilita o fenômeno de multissemiose.

A complexificação das esferas em meio digital ocorre a partir da nova tecnologia, o que não nos permite descartar a tese de Araújo (2006). Com isso, acreditamos que a internet propicie não somente a reprodução de esferas já existentes em outros meios, mas também a criação de novas esferas por meio da produção de tipos relativamente estáveis de enunciados. Podemos considerar a existência de uma esfera digital ou eletrônica que se sobrepõe às

\footnotetext{
${ }^{43}$ Na tese de Araújo (2006), o autor não estabelece uma distinção conceitual entre os termos hipertexto e hipertextualidade.
} 
demais e modifica aspectos dos enunciados. No caso da transposição do gênero reportagem do jornal impresso ao digital, notamos que a forma composicional seleciona fatores que propiciam a hipertextualidade de forma distinta. Enquanto no impresso, as relações dialógicas hipertextuais são mais favorecidas por meio da organização hiperestrutural dos enunciados, no online a hipertextualidade é potencializada pela presença do hipertexto e dos nós remissivos.

As esferas não permanecem isoladas umas das outras, mas estabelecem fronteiras entre si. Os enunciados, por sua vez, são produzidos nas esferas e rompem tais fronteiras de acordo com as diferentes situações de comunicação a que são expostos e pela alternância dos sujeitos falantes. No texto O problema do conteúdo, do material e da forma na criação literária (2008 [1923-24]), Bakhtin faz uma reflexão sobre as fronteiras entre as esferas:

\footnotetext{
É somente quando, em suas fronteiras, nasce a necessidade absoluta de tal perspectiva na sua originalidade criativa, que seu verdadeiro fundamento e justificação são encontrados, mas dentro de si, sem qualquer participação a unidade da cultura é apenas um fato bruto, e sua originalidade pode se apresentar simplesmente como arbitrária (...) (Bakhtin, 2008 [1923-24], p. 40) ${ }^{44}$
}

$\mathrm{Na}$ internet, os enunciados que emanam do conjunto de esferas da rede refletem não somente as suas condições específicas encontradas fora dela, mas também as condições específicas provenientes da multissemiose, tal como aponta Araújo (2006), característica do meio digital. Contudo, na esteira da ideia de que a esfera digital entrecruza-se com as demais esferas da atividade humana no meio digital, a hipertextualidade e o hipertexto não podem ser considerados traços caracterizadores exclusivos da primeira. Principalmente por considerarmos que tais elementos também se encontram em enunciados impressos, cujos respectivos gêneros não partilham da multissemiose típica do meio digital.

Considerar a internet um espaço de interação entre sujeitos falantes, um ciberespaço, em que diferentes esferas são produzidas, constituídas e reproduzidas, ao mesmo tempo em que a esfera digital possa configurar parte desse conglomerado é um fato que traz implicações metodológico-analíticas importantes para a tese. Teremos que avaliar na medida em que uma reportagem da FO difere de uma da FSP considerando os meios em

\footnotetext{
44 “'C'est seulement lorsque, sur leurs frontières, naît la nécessité absolue de ce point de vue dans son originalité créatrice, qu'il trouve son fondement et sa justification véritables; mais à l'intérieur de lui-même, hors de toute participation à l'unité de la culture, il n'est qu'un fait brut, et son originalité peut se présenter simplement comme un arbitraire (...)" (Bakhtin, 2008 [1923-24], p. 40)
} 
que são constituídas, ao mesmo tempo em que nos interessa verificar de que maneira seus enunciados selecionados constituem as diferentes esferas.

Uma das hipóteses acerca da análise do corpus é exatamente encontrar exemplos que demonstrem tais fatos, apontando os pontos de convergência, bem como de divergência entre um meio e outro e suas esferas ideológicas. Acreditamos que a análise das relações dialógicas hipertextuais nos revelará, em parte, os limites da interferência entre os meios impressos e os digitais e, consequentemente, o comportamento dos enunciados nas fronteiras das esferas delimitadas para análise.

Após a resenha crítica dos autores selecionados ao longo do capítulo, sintetizamos nossa reflexão sobre a internet a partir de alguns posicionamentos teóricos. Assumimos, em primeiro lugar, que o suporte equivale a todo aparato físico e tecnológico que sustenta um meio, tal como o aparelho de televisão ou rádio, o telefone fixo ou portátil, o computador, o papel, o papiro, etc., não devendo ser confundido com o próprio meio.

Definimos o meio como um conjunto de fatores caracterizado: pelo suporte e pelas semioses pertinentes à tecnologia; pelos enunciados e gêneros discursivos que atravessam as esferas de determinado meio; pela relação entre locutores e interlocutores; bem como pelo conjunto de práticas de produção, circulação e recepção de enunciados Nesse sentido, nossa visão sobre o meio difere do conceito de mídium ${ }^{45}$. Ao discorrermos sobre o jornal impresso e o jornal digital, os situamos, respectivamente, nas culturas impressas e digitais.

A internet, por sua vez, é um meio digital sustentado por suportes diversos (telefones e computadores fixos ou portáteis, bem como tablets e até mesmo a televisão); caracterizada por um sistema de semioses complexo denominado multimodalidade; dotada de enunciados e gêneros discursivos produzidos dentro ou fora dela circulando por diferentes esferas da atividade humana; constituída da interatividade de usuários-autores e usuários-leitores; cujas práticas de produção, circulação e recepção são regidas pela acessibilidade ilimitada, pelas possibilidades de armazenamento e compartilhamento de dados, bem como pela velocidade e instantaneidade de veiculação da informação. Tais características apontam a complexidade desse meio que, assim como a definição de ciberespaço de Lévy, é um espaço digital de comunicação e interação entre os sujeitos. Em nossa tese, internet, meio digital e ciberespaço são conceitos equivalentes.

\footnotetext{
${ }^{45}$ No sentido em que o mídium é constituído pelo modo de inscrição (impresso ou digital), o tipo de simbolização (escrita, fala, imagem), a língua natural como código de comunicação social e o suporte.
} 
Após o estudo de noções-chave de diferentes teorias, tal como o meio, numa acepção que o considera a extensão do homem (McLuhan); o mídium como um conjunto de dispositivos que propiciam o processo de transmissão da informação (Debray) e o ciberespaço enquanto espaço digital de interação entre os sujeitos (Lévy), buscamos apresentar nossa proposta no que tange à definição de internet no escopo dessa tese.

Sinteticamente, a internet é compreendida como meio digital ou ciberespaço sustentado tecnologicamente e materialmente pelo computador e suas ferramentas e até por outros dispositivos eletrônicos, como o próprio telefone. Adotamos o postulado de Lévy (1996 e 1999) que descreve o ciberespaço como o próprio desdobramento da tecnologia digital em um espaço que abriga a interação entre os sujeitos. Ao propor a internet como um conglomerado de esferas da atividade humana, fato propiciado pela própria constituição do meio, não descartamos a noção de esfera digital ou eletrônica, proposta por Araújo (2006), que farão fronteira com as demais esferas constitutivas da rede, mas sim, consideramos a sobreposição da esfera digital sobre as demais. 


\title{
CAPít́tulO 3. \\ O GÊNERO REPORTAGEM DE DIVULGAÇÃO CIENTÍFICA EM \\ FOCO:
}

\author{
PROPOSTA PARA UMA ANÁLISE DIALÓGICA DA \\ HIPERTEXTUALIDADE
}

\begin{abstract}
Quando um rio corta, corta-se de vez
o discurso-rio de água que ele fazia; cortado, a água se quebra em pedaços, em poços de água, em água paralítica. Em situação de poço, a água equivale a uma palavra em situação dicionária: isolada, estanque no poço dela mesma, e porque assim estancada, muda, e muda porque com nenhuma comunica, porque cortou-se a sintaxe desse rio,

o fio de água por que ele discorria.

O curso de um rio, seu discurso-rio, chega raramente a se reatar de vez; um rio precisa de muito fio de água para refazer o fio antigo que ofez. Salvo a grandiloqüencia de uma cheia lhe impondo interina outra linguagem, um rio precisa de muita água em fios para que todos os poços se enfrasem: se reatando, de um para outro poço, em frases curtas, então frase e frase, até a sentença-rio do discurso único em que se tem voz a seca ele combate.
\end{abstract}

(Rios sem discurso, João Cabral de Melo Neto, 1979)

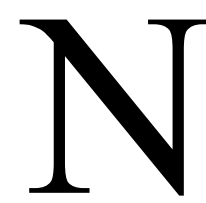

o primeiro capítulo, defendemos que a hipertextualidade é um tipo de relação dialógica entre enunciados que são visivelmente articulados por nós remissivos de diferentes naturezas, conforme detalhamos nos capítulos analíticos. A hipertextualidade suscita diferentes relações dialógicas nos discursos em que estão situadas e são particularmente potencializadas por seu meio de veiculação. Considerando que o corpus da pesquisa foi composto de enunciados provenientes dos meios impresso e digital, foi possível observar como a hipertextualidade opera de acordo com os 
recursos tecnológicos e semióticos pertinentes a cada tipo de publicação. No entanto, compreender de que forma são constituídas as relações dialógicas hipertextuais no gênero reportagem de divulgação científica impresso e digital a partir dos preceitos da Teoria Dialógica de Bakhtin e seu Círculo pressupõe levar em consideração o enunciado em sua dimensão linguística e extralinguística. No caso de nossa análise, consideramos, sobretudo, as dimensões: verbal, visual e verbo-visual.

Nas análises encontradas nas obras de Bakhtin não é evidente a proposta de um dispositivo que se proponha a servir de modelo de análise para outras obras e diferentes tipos de enunciados. Mesmo porque, Bakhtin contemplou, especificamente, enunciados da esfera literária. No entanto, em Problemas da Poética de Dostoiévski (2008[1963]) Bakhtin delineia a proposta de uma disciplina capaz de apreender as relações dialógicas previstas entre quaisquer enunciados concretos.

A Metalinguística ${ }^{46}$, ou Translinguística segundo a tradução de Todorov (1981) para o francês, deve ser compreendida como a disciplina cujo objeto de análise concentra-se nos elementos linguísticos e extralinguísticos constitutivos do enunciado a fim de compreender as relações dialógicas que o atravessam. Em $P P D$, no início do quarto e último capítulo sobre $O$ discurso em Dostoiévski, Bakhtin discorre acerca da importância dos elementos linguísticos e seu encontro com o metalinguístico, ou seja, aquilo que está além da língua, enquanto objeto da linguística da época:

(...) temos em vista o discurso, ou seja, a língua em sua integridade concreta e viva, e não a língua como objeto específico da linguística, obtido por meio de uma abstração absolutamente legítima e necessária de alguns aspectos, de alguns aspectos da vida concreta do discurso. Mas são justamente esses aspectos, abstraídos da linguística, os que têm importância primordial para os nossos fins. Por esse motivo, nossas análises não são linguísticas no sentido rigoroso do termo. Podem ser situadas na metalinguística, subentendendo-se como um estudo (...) daqueles aspectos da vida do discurso que ultrapassam (...) os limites da linguística. As pesquisas metalinguísticas, evidentemente, não podem ignorar a linguística e devem aplicar seus resultados. (Bakhtin, 2010 [1963], p. 207)

A partir do constructo teórico de Bakhtin, estabeleceremos os princípios metodológicos para a análise que nos levou à consolidação da tese de que a hipertextualidade

\footnotetext{
${ }^{46}$ Lembramos que a noção de Metalinguística de Bakhtin nada tem a ver com aquela de Jakobson (1963) que a propõe como uma função de linguagem, referindo-se ao uso da língua para questionar e explicar a própria língua.
} 
é uma modalidade de relação dialógica. Para tanto, propomos uma análise que considera desde a palavra 'em situação de poço' estancada no plano da significação linguística ao 'discurso-rio' feito de inúmeros fios enunciativos, moldada por meio da apropriação da teoria dialógica e os indícios dados pelo corpus. Com base no construto teóricometodológico desenvolvido por Bakhtin em suas análises, o presente capítulo não se restringe à descrição de procedimentos de escolha e seleção dos enunciados que formam o corpus, muito menos à mera apresentação das categorias de análise que serão empregadas para verificar as relações dialógicas hipertextuais. Pretendemos desenvolver um modelo de análise inspirado na Metalinguística.

Iniciamos expondo os critérios que nortearam a constituição do corpus e das categorias de análise a partir do detalhamento do processo de mapeamento e escolha dos enunciados, bem como dos fatores que justificaram a seleção do corpus. Em seguida, descrevemos as diferentes etapas de recorte e seleção dos enunciados da FO e da FSP, por meio dos filtros que levaram à composição do corpus final.

Considerando a importância da temporalidade que incide sobre o corpus, formado por reportagens publicadas em um período de 8 anos, e da contextualização sócio-histórica do enunciado na data de sua publicação, percebemos que seria necessário atentar para a própria esfera de produção e a constituição editorial das publicações. Logo, o próximo item tratará da caracterização do jornal ao longo dos anos, com base no Manual da Redação (2010) que contém o projeto editorial da Folha. Uma vez definido o corpus, discorremos acerca das categorias de análise, considerando tanto os aspectos linguísticos quanto os extralinguísticos de cada enunciado, a partir dos elementos constituintes do gênero reportagem, a saber, a forma composicional, o estilo, e o conteúdo temático nas suas esferas de produção e circulação.

Antes de finalizar o capítulo, acrescentamos uma discussão a respeito das esferas da atividade humana das quais emergem os enunciados analisados. A especificidade encontrada na tese revela que as reportagens, além de serem geradas pela relação dialógica entre as esferas jornalística e científica, são fortemente atravessadas pelo discurso político nos anos iniciais do corpus. O estabelecimento do espaço da DC nas páginas da FSP ao longo do tempo equivale a uma consolidação no processo de formação de uma cultura científica do próprio país. 


\subsection{Seleção do corpus: o gênero reportagem de $\mathrm{DC}^{47}$ sob análise}

As coerções do gênero reportagem escrita, tanto em meio impresso quanto digital, levam à concretização de enunciados cujas características são: o apagamento das marcas do estilo individual do autor e o alto grau de informatividade empenhado a fim de garantir um efeito de maior imparcialidade no que tange aos pontos de vista adotados pelo mesmo autor e pela orientação editorial do jornal (Machado, 2007). De acordo com tais propriedades, apontadas na pesquisa de mestrado anterior, examinou-se que o aparecimento do nó remissivo eletrônico foi mais pungente em reportagens do que em artigos, cujas coerções favorecem a opinião individual do autor, evidenciando o seu estilo individual.

Se em um primeiro momento verificamos as coerções do gênero reportagem de DC somente em meio digital sob o ponto de vista do aproveitamento do nó eletrônico, a atual tese redireciona a análise ao estender-se não somente ao meio impresso, mas também a outras formas de concretização de enunciados hipertextuais que suscitam relações semânticodialógicas específicas. Por outras formas de concretização desses enunciados, referimo-nos tanto a elementos verbais quanto verbo-visuais que ocupam o lugar do nó remissivo. Ao passo em que a reportagem digital possui atributos próprios, já que a tecnologia digital permite o acesso imediato a outros enunciados por meio do hiperlink, a reportagem impressa também apresenta particularidades.

A hipertextualidade sugere a relação entre enunciados dispostos em planos distintos. $\mathrm{Na}$ pesquisa anterior (Ferraz 2007), pudemos identificar três planos de relações entre enunciados: relação de um enunciado A com um enunciado B, em que ambos faziam parte da mesma reportagem; relação de um enunciado A da reportagem com um enunciado B que fazia parte de outra seção da revista eletrônica; e relação entre um enunciado $A$ da reportagem com um enunciado $\mathrm{B}$ situado em uma página exterior. Os resultados dessa análise demonstraram que a hipertextualidade possuía como ponto de partida um enunciado fonte da reportagem selecionada no corpus, com algum outro enunciado que poderia ser interno ou externo à publicação em diferentes níveis.

\footnotetext{
${ }^{47}$ A opção pelo discurso de divulgação científica foi determinada pela filiação dessa pesquisa ao projeto maior intitulado Divulgação científica: linguagem, esferas e gêneros coordenado pela Prof. ${ }^{a}$ Dr. ${ }^{a}$ Sheila Vieira de Camargo Grillo, cujo principal interesse é analisar as formas de funcionamento da DC enquanto modalidade dialógica, partindo da premissa de que seus gêneros são gerados nas fronteiras de diferentes esferas, a saber, a jornalística, a literária, a científica, entre outras.
} 
Transportando-nos ao corpus atual, deparamo-nos com o meio impresso, cujo suporte e tipo de inscrição pertencem à outra ordem. Nosso desafio foi identificar de que forma os planos estão dispostos nas páginas do jornal impresso, como mostraremos nos próximos capítulos. Contudo, as observações iniciais já apontavam para um fato que diferencia os enunciados em cada meio e que nos dizem algo a respeito da constituição do gênero reportagem de DC impresso. Quando a hipertextualidade opera em meio digital, articulando enunciados em planos diferenciados por meio do recurso do nó eletrônico, o leitor presumido depara-se com reportagens cuja conclusibilidade é bem marcada, uma vez que uma página comporta somente um enunciado. Em outras palavras, cada enunciado no meio digital confere uma reportagem. Não desprezamos a presença de outras reportagens relacionadas à reportagem fonte, no entanto a forma de vinculação ocorre diferentemente entre um meio e outro.

No meio impresso, os mesmos enunciados veiculados no digital conservam a sua conclusibilidade e autonomia, ou seja, um enunciado pode equivaler a uma reportagem. No entanto, a reportagem também pode ser constituída por meio da injunção de mais de um enunciado que, em meio digital, é tido como uma reportagem única. Com isso, queremos apontar para a particularidade do gênero de DC impresso. Enquanto os planos de remissão digital remetem o leitor a diferentes páginas e sites, o jornal impresso, cujo caráter é bidimensional (Machado, 2011), parece ser capaz de abrigar diferentes planos em uma única página. A apreensão do conteúdo temático de um único enunciado - tal como exploraremos ainda no terceiro capítulo - é diferente de quando há outros enunciados que, apesar de pertencerem a outros planos, são trazidos para o mesmo espaço físico. A partir dos gráficos abaixo, ilustramos a maneira como os diferentes planos podem ser encontrados em seus respectivos meios: 
Gráfico (1) Representação de indexação de planos em meio digital

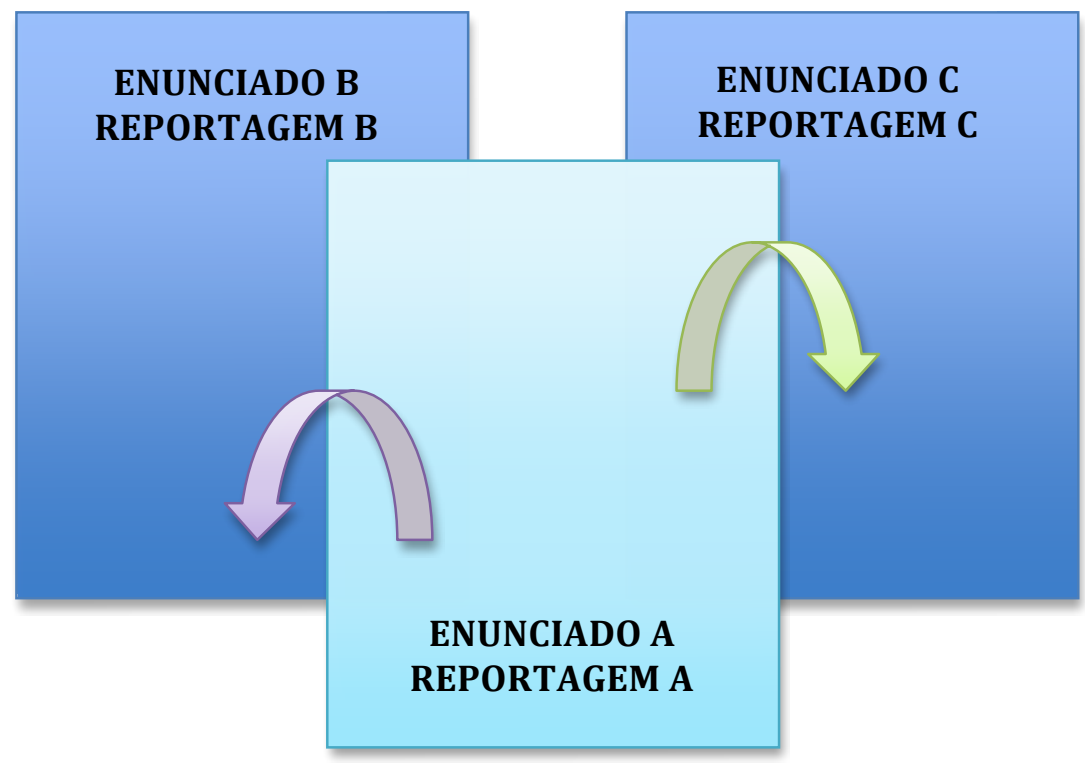

Gráfico (2) Representação de indexação de planos em meio impresso

A comparação entre os dois gráficos ${ }^{48}$ salienta a relação hipertextual entre os enunciados. Primeiramente, vemos no gráfico (1), os diferentes planos de remissão em meio digital. Retomando o que expusemos acima, cada plano corresponde a uma página que, por sua vez, comporta um único enunciado. Cada enunciado é apreendido pelo leitor como uma reportagem autônoma, cuja conclusibilidade é balizada pelo conteúdo temático, ou seja, a forma com que a realidade é refletida e refratada no enunciado, e pela influência do suporte e do meio digital que operam com um tipo de indexação específica, por meio do nó eletrônico. A figura (1) fornece um exemplo de como o nó eletrônico indexa demais enunciados ao enunciado fonte:

Figura (1) - Reportagem da $\mathrm{FO}$ e outras reportagens relacionadas

\section{$17 / 10 / 2005-13 h 55$ \\ Assinatura para vôo de astronauta brasileiro sai nesta terça}

da Folha Online

O presidente da AEB (Agência Espacial Brasileira), Sergio Gaudenzi, vai assinar nesta terça-feira o contrato para a viagem do primeiro astronauta brasileiro, Marcos César Pontes, à ISS (Estação Espacial Internacional).

O presidente da Agência Espacial Russa (Roscosmos), Anatoli Perminov, também assinará o documento. A cerimônia realizada em Moscou (Rússia) terá a presença de Luiz Inácio Lula da Silva e do presidente russo, Vladimir Putin.

Em sua viagem --realizada na nave russa Soyuz--, Pontes deve levar experimentos científicos brasileiros para execução em ambiente de microgravidade.



A viagem do brasileiro pode ser realizada somente em 2007, já que a tripulação das próximas duas expedições à ISS está fechada, informou a Roscosmos na última sexta-feira.

Em virtude deste contrato, o Brasil pode pagar à Rússia entre US $\$ 10$ milhões e US $\$ 20$ milhões, que serão investidos no desenvolvimento do programa espacial.

Além disso, o Brasil, que faz parte do consórcio da ISS junto com outros 16 países, comprometeu-se a investir cerca de US $\$ 80$ milhões nos próximos seis anos em sua indústria para a fabricação de equipamentos que seriam usados na estação espacial.

Jấ a Rússia cooperaria com a fabricaçẫo de foguetes portadores brasileiros e com a construção de um centro de lançamentos espaciais no Brasil.

Com agència Efe

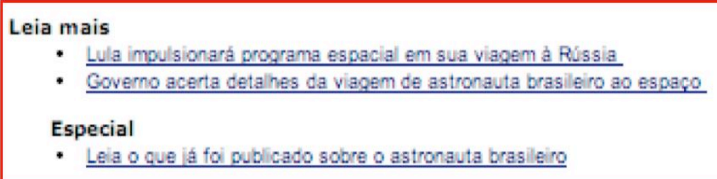

${ }^{48}$ A elaboração dos gráficos realizou-se por meio da observação das reportagens da Folha de S. Paulo e da Folha Online selecionadas no corpus e foi particularmente baseada na reportagem do dia 9 de novembro de 2000 cuja análise será detalhada no capítulo 4 . 
O gráfico (2), apresentado anteriormente, aponta para a constituição de reportagens na FSP. Os enunciados que formam reportagens autônomas na FO são agrupados atribuindo novas fronteiras de conclusibilidade aos enunciados da página impressa. Os mesmos enunciados A e B com os quais se depara o leitor na publicação digital formam uma única reportagem no jornal impresso. Portanto, podemos considerar que o gênero reportagem de DC em meio impresso pode ser constituído por um único enunciado ou por um conjunto deles, como vimos em momentos distintos da análise. Nesse caso, a conclusibilidade é delimitada não somente pelo conteúdo temático, mas também pelos elementos peritextuais e composicionais de cada enunciado, tal como o emprego do 'chapéu' ${ }^{49}$ para indicar o início de cada reportagem.

Outro aspecto que merece reflexão em nossa análise é o fato de as reportagens da FSP e da FO serem constituídas pela mesma forma lógica, ou seja, o material verbal dos enunciados é idêntico em ambas as publicações. De acordo com a proposição de Bakhtin em Problemas da Poética de Dostoiévski (2010 [1963], p. 209), uma forma lógica revestida por um juízo de valor definido pode ser concretizada em diferentes contextos ou tempo, contudo as relações dialógicas geradas em cada caso serão sempre únicas, tal como explica o autor no caso a seguir:

\footnotetext{
"A vida é boa." "A vida é boa." Estamos diante de dois juízos absolutamente idênticos, em essência, diante de um único juízo, escrito (ou pronunciado) por duas vezes, mas esse 'dois' se refere apenas à materialização da palavra, e não ao próprio juízo. É verdade que aqui podemos falar de relação lógica de identidade entre dois juízos. Mas se esse juízo puder expressar-se em duas enunciações de dois diferentes sujeitos, entre ela surgirão relações dialógicas (acordo, afirmação).” (Bakhtin, 2010 [1963], p. 110)
}

A concretização de cada forma lógica no enunciado equivale a uma realização única e irrepetível do processo de enunciação, o que nos levou a considerar que os jornais, apesar de se valerem da mesma materialidade linguística, veiculam enunciados distintos. Tal contribuição da teoria bakhtiniana suscitou uma nova questão para o nosso corpus: se confrontarmos o material linguístico e visual, juntamente com a forma lógica e os valores de juízo sobre a própria vida de cada publicação, que tipo de relação dialógica podemos

\footnotetext{
${ }^{49}$ Segundo o Manual da Redação da FSP (1997), o chapéu “é a palavra ou expressão curta colocada acima de um título. Usada para indicar o assunto de que trata o texto ou os textos que vêm abaixo dela." (p. 130-131).
} 
observar? Trata-se de um questionamento que procuramos desenvolver ao longo dos capítulos de análise.

Instigados pelo funcionamento da hipertextualidade em diferentes meios, selecionamos um veículo midiático de grande circulação entre a população de não especialistas que possuísse mais de um tipo de meio ou dispositivo de registro, no caso, o impresso e o digital. Ao optar por uma publicação que possui vertente impressa e digital, consideramos que o jornal seria uma escolha que favoreceria o levantamento e a análise dos dados por duas razões. A primeira delas diz respeito à expressividade da tiragem de exemplares e à maior circulação dos jornais que, em sua maioria, possuem sites na internet. Outro motivo que conduziu à escolha do jornal foi a sua periodicidade, que também é uma característica fundamental do meio digital. Obviamente, a instantaneidade e a velocidade da publicação na internet são diferentes daquelas encontradas nos jornais impressos. De certa forma, a atualização ininterrupta do jornal online possivelmente apresentará diferenças nos modos de produção e apreensão de sentido de seus gêneros em relação ao jornal impresso.

A partir da preferência pelo jornal, realizou-se um estudo detalhado e comparativo dos dois jornais de maior circulação no estado de São Paulo, O Estado de S. Paulo e Folha de S. Paulo. A opção pela FSP em detrimento de OESP, cujas características são semelhantes, em termos de tiragem e leitor presumido, deu-se pela sua publicação digital. Em sua versão digital, a FSP é desenvolvida pelo portal UOL, o que propicia uma melhor articulação de seus enunciados internos, além de possibilitar o armazenamento e o fácil acesso a enunciados anteriores.

Por meio de uma pesquisa de mapeamento de corpus que comparou as publicações digitais da FSP e de OESP, observamos que a primeira apresenta um mecanismo de remissão e organização hipertextual melhor engendrado, cuja dinâmica relaciona as diversas seções da publicação entre si. A variedade de gêneros discursivos é maior e o uso do link eletrônico mais produtivo com diferentes tipos de remissão, a saber: remissão de um fragmento de enunciado a um enunciado maior, anexação de outros enunciados ao final de cada texto e índices remissivos sob forma de links.

De acordo com o estudo acima relatado, o corpus foi, então, formado de reportagens de DC provenientes de duas publicações do Grupo Folha: o jornal eletrônico Folha Online e o jornal impresso Folha de S. Paulo. Primeiramente, foram levantadas todas as reportagens veiculadas nos meses de novembro de cada ano entre 2000 e 2008, em cada publicação. O ponto de partida para o levantamento das reportagens considerou o primeiro ano e mês de publicação de reportagens de DC na FO. 
A FO surgiu em 1999, pouco tempo depois da abertura da internet para uso comercial no Brasil (1995), como o "primeiro jornal em tempo real em língua portuguesa", segundo o título na página da própria publicação. A seção Ciência e Saúde da FO publica suas primeiras reportagens no mês de novembro de 2000. Portanto, o primeiro recorte feito para a seleção das reportagens diz respeito ao mês de novembro de cada ano, de 2000 a 2008, uma vez que o intuito será o de se realizar uma análise diacrônica do corpus. Após o primeiro levantamento das reportagens considerando o período estipulado, os dados foram cruzados para que somente as reportagens que ocorressem em ambas as publicações fossem selecionadas.

Para a seleção das reportagens da FO, realizamos uma pesquisa diretamente no site da FO, por meio do mecanismo de busca lá disposto. Na seção 'Busca', como é mostrado na figura (2), o critério utilizado para a pesquisa repetiu-se em todos os anos, tendo como palavra-chave escolhida 'Ciência', na editoria 'Ciência'. Isso garantiu que o filtro de seleção das reportagens não buscasse qualquer reportagem que tratasse de algum assunto científico, mas somente aquelas pertencentes obrigatoriamente à seção Ciência e Saúde do site. A escolha dos períodos também obedeceu ao seguinte esquema: do primeiro dia de novembro daquele ano, até o primeiro dia de dezembro do mesmo ano. Ao todo, foram realizadas nove pesquisas que contemplaram cada ano selecionado, de 2000 a 2008.

Figura (2) - Reprodução do mecanismo de busca da FO

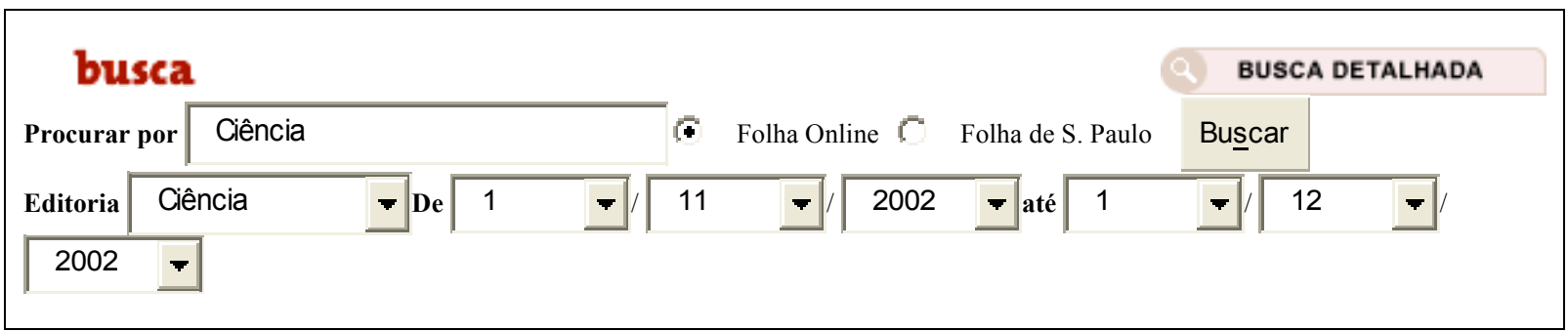

A partir da escolha das reportagens digitais encontradas por meio da pesquisa, tornouse possível a contagem geral do número de enunciados desse gênero publicados em cada ano. Após o levantamento, quantificação e organização dos dados de cada reportagem de DC encontrada na FO, iniciamos o processo de seleção das mesmas na FSP.

A composição do corpus impresso deu-se, inicialmente, com uma visita ao Banco de Dados Folha, onde foram solicitados todos os jornais dos meses de novembro de cada ano, de 2000 a 2008, assim como havíamos feito com as reportagens da FO. Abaixo, 
apresentamos as tabelas (2) e (3) que se referem à primeira seleção de enunciados da FO e da FSP, respectivamente. Lembramos que, na FO, cada enunciado equivale a uma reportagem, mas que o mesmo não ocorre na FSP, em que mais de um enunciado pode ser mobilizado para compor uma única reportagem.

Tabela (2) Ocorrências de enunciados na FO entre 2000 e 2008

\begin{tabular}{|l|c|}
\hline Mês / Ano & Textos da FO \\
\hline Nov / 2000 & 142 \\
\hline Nov / 2001 & 254 \\
\hline Nov / 2002 & 112 \\
\hline Nov / 2003 & 178 \\
\hline Nov / 2004 & 94 \\
\hline Nov / 2005 & 74 \\
\hline Nov / 2006 & 153 \\
\hline Nov / 2007 & 151 \\
\hline Nov / 2008 & 104 \\
\hline
\end{tabular}

Tabela (3) Ocorrências de enunciados na FSP entre 2000 e 2008

\begin{tabular}{|c|c|}
\hline Mês / Ano & Textos da FSP \\
\hline Nov / 2000 & 119 \\
\hline Nov / 2001 & 104 \\
\hline Nov / 2002 & 93 \\
\hline Nov / 2003 & 78 \\
\hline Nov / 2004 & 82 \\
\hline Nov / 2005 & 78 \\
\hline Nov / 2006 & 78 \\
\hline Nov / 2007 & 71 \\
\hline Nov / 2008 & 72 \\
\hline
\end{tabular}

Além de determinarmos a conclusibilidade dos enunciados selecionados e de fazermos as primeiras observações de mudanças de layout e apresentação da seção Folha Ciência, o material selecionado foi copiado e digitalizado. Tornou-se possível notar que a posição ocupada pelo jornal ao longo dos anos é variável, contudo, está sempre posicionada no primeiro caderno do jornal. Por exemplo, em novembro de 2000, a seção Folha Ciência é publicada no primeiro caderno, sem localização exata entre as seções. Em novembro de 2001, também há oscilação da posição da seção no jornal, porém permanecendo sempre no primeiro caderno. A partir do ano de 2002, a seção Folha Ciência situa-se na última página 
do primeiro caderno ocupando frente e verso, posição que se mantém até o momento, e não há mais publicação da seção aos domingos. Ainda em 2001, observa-se o aparecimento de um item importante que perdurará por vários anos na seção, o box 'Panorama', composto por uma seleção que varia de três até cinco notas ou notícias. Condiremos que a inserção de tais seções é um indício da influência da publicação digital sobre a impressa.

Somente em 2006, a seção deixa de ser publicada na primeira segunda-feira do mês $(06 / 11)$ para dar lugar à 'Entrevista da $2^{\mathrm{a}}$, . Nos anos seguintes, a seção, que passa a ser intitulada Ciência, é publicada juntamente com a 'Entrevista da $2^{\mathrm{a}}$ '. Observa-se ainda que, nesse mesmo ano, um mecanismo de remissão entre o conteúdo do jornal impresso e o jornal digital é implementado com a introdução de nós representados por símbolos. No exemplo apontado pela figura (3), o símbolo [>> ] e o endereço eletrônico que o sucede articulam um enunciado do jornal impresso "Veja mais fotos do telescópio Hubble" a outro enunciado disposto no site da agência espacial NASA, conforme indicado.

Figura (3) - Exemplo de mecanismo remissivo entre as publicações impressas e digitais

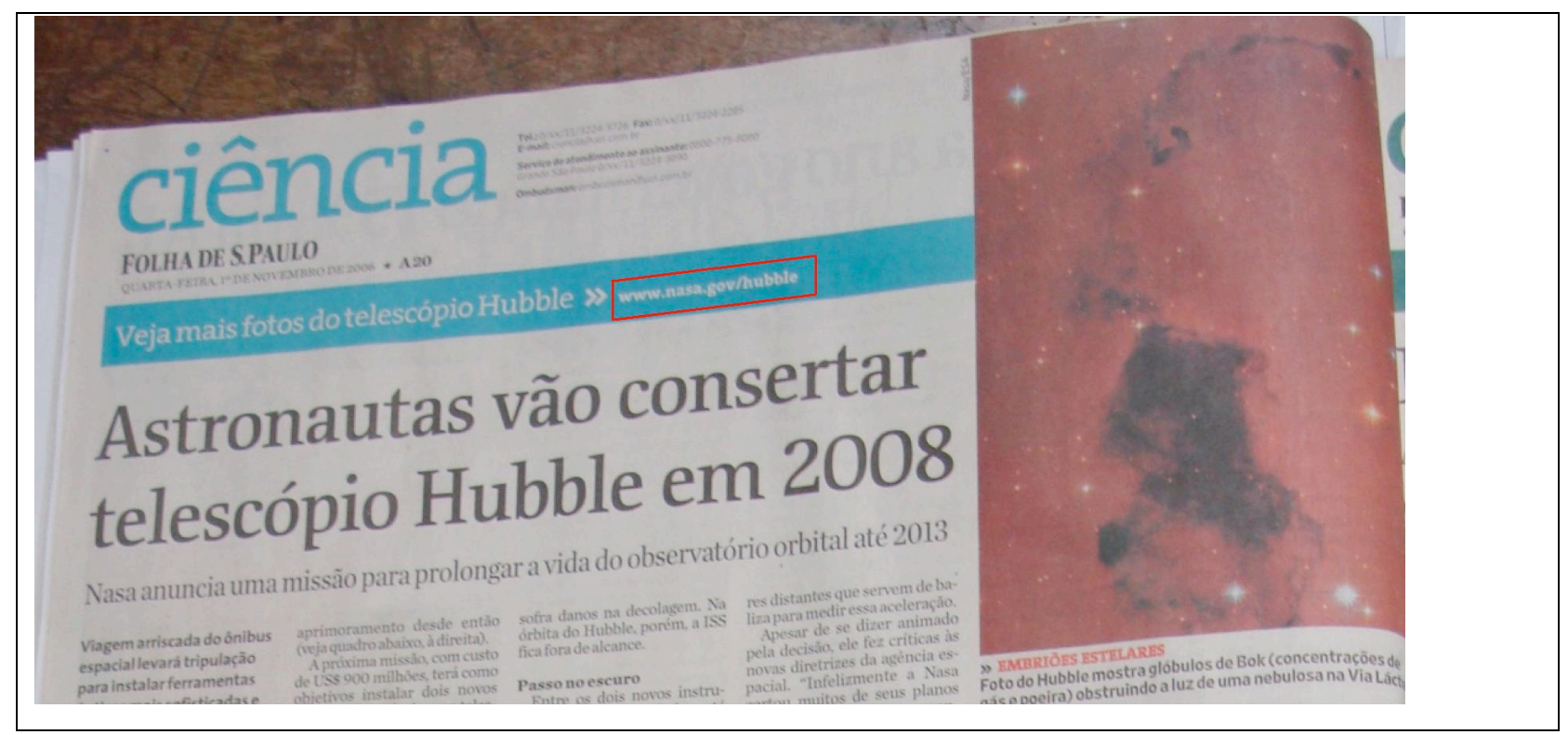

Na FSP, artigos e reportagens sobre ciência estão espalhados por diferentes seções do jornal, como na seção 'Saúde' do caderno 'Cotidiano' e em artigos no caderno 'Mais!', assinados por Marcelo Leite e Marcelo Gleiser. No entanto, foram selecionados somente aqueles que pertencem à seção Folha Ciência. Segundo a agência de notícias do Grupo Folha, o Folhapress, essa seção: 
leva até o leitor reportagens sobre as mais novas pesquisas no mundo das ciências naturais, como engenharia genética, clonagem, arqueologia, cosmologia, astronomia, mudança climática global, florestas etc. A ênfase no didatismo de Ciência é complementada com uso frequente de quadros explicativos, mapas e fotografias. A seção pode ser transmitida diariamente, exceto aos domingos, a partir das 20h do dia anterior (...). Disponível em http://www.folhapress.com.br/.

As reportagens de DC dividem espaço com as peças publicitárias que, geralmente, ocupam mais de $50 \%$ do espaço total dedicado à seção. Os anúncios são de ordem bastante variável e apresentam produtos que vão desde itens de supermercado a empreendimentos imobiliários. A partir das reportagens pré-selecionadas, realizamos uma triagem que considerou as reportagens comuns a ambas as publicações. Tal triagem foi feita por meio dos títulos de cada enunciado, que apresentariam certa ou total semelhança entre eles. De acordo com a tabela (4), torna-se possível visualizar o emprego desse critério e o resultado quantitativo dessa etapa da seleção do corpus. Lembramos que a periodicidade da seção Folha Ciência, da FSP, e Ciência, da FO, é diária, o que justifica a quantidade de textos encontrados.

Tabela (4) Ocorrências de textos comuns em ambas as publicações

\begin{tabular}{|l|c|c|c|}
\hline Mês / Ano & $\begin{array}{c}\text { Enunciados } \\
\text { FO }\end{array}$ & $\begin{array}{c}\text { Enunciados } \\
\text { FSP }\end{array}$ & $\begin{array}{c}\text { Ocorrência nas } \\
\text { duas } \\
\text { publicações }\end{array}$ \\
\hline Nov / 2000 & 142 & 119 & 23 \\
\hline Nov / 2001 & 254 & 104 & 54 \\
\hline Nov / 2002 & 112 & 93 & 25 \\
\hline Nov / 2003 & 178 & 78 & 61 \\
\hline Nov / 2004 & 94 & 82 & 9 \\
\hline Nov / 2005 & 74 & 78 & 30 \\
\hline Nov / 2006 & 153 & 78 & 42 \\
\hline Nov / 2007 & 151 & 71 & 21 \\
\hline Nov / 2008 & 104 & 72 & 21 \\
\hline
\end{tabular}

De acordo com a seleção dos enunciados tal como apresentamos na tabela anterior, fizemos um novo recorte que considerou a quantidade de ocorrências comuns de acordo com o dia da publicação. Foram selecionadas as datas em que houve maior incidência de reportagens comuns, com, no mínimo, duas ocorrências. Nos anos de 2003 e 2006, o grande índice de reportagens e, por consequência, reportagens comuns a ambas as publicações, fez com que o número mínimo considerado fosse de três ocorrências por dia. Aliado a isso, o 
último critério empregado para compor o corpus partiu da exclusão de enunciados tais como notas e notícias, ou seja, todos os textos que não pertenciam ao gênero reportagem de DC.

A análise do corpus compreende as reportagens publicadas entre os anos 2000 e a 2008. Optamos por desenvolver dois capítulos de análise com base em dois argumentos: primeiro diz respeito ao modo com que as questões políticas foram instauradas nas reportagens de DC ao longo dos anos, e o segundo, devido a uma mudança visual e estrutural significativa no modo de apresentação da página do jornal impresso a partir de 2006, apesar de não termos encontrado quaisquer registros de uma orientação editorial que apontasse para isso. Essa cisão deu-se com a análise inicial de reportagens das seguintes datas: 09/11/2000, 28/11/2005, 10/11/2006 e 14/11/2008. Como resultado da análise parcial, o capítulo 4 será dedicado às reportagens dos anos 2000, 2003 e 2005, ao passo que o capítulo seguinte contemplará as análises dos anos 2006, 2007 e 2008.

A constituição final dos enunciados que compõem o corpus está representada pelos títulos de cada um como disposto na tabela (5) a seguir:

Tabela (5) Seleção de enunciados que compõem o corpus final da pesquisa

\begin{tabular}{|c|c|c|}
\hline Data & Título publicado na FO & Título publicado na FSP \\
\hline \multicolumn{3}{|c|}{2000} \\
\hline $09 / 11$ & $\begin{array}{l}\text { FHC omite as florestas ao abordar } \\
\text { mudanças no clima }\end{array}$ & $\begin{array}{l}\text { FHC omite as florestas ao abordar mudanças no } \\
\text { clima }\end{array}$ \\
\hline $09 / 11$ & Presidente cita até Trótski em seu discurso & Presidente cita até Trótski em seu discurso \\
\hline $09 / 11$ & Amazônia tinha fazenda de peixes & Amazônia tinha fazenda de peixes \\
\hline \multicolumn{3}{|c|}{2003} \\
\hline $07 / 11$ & Deserto terrestre descarta vida marciana & Deserto terrestre descarta vida marciana \\
\hline 07/11 & $\begin{array}{l}\text { ONU adia debate sobre clonagem por } 2 \\
\text { anos }\end{array}$ & ONU adia debate sobre clonagem por 2 anos \\
\hline $07 / 11$ & Secretário-executivo deixa cargo no MCT & Secretário-executivo deixa cargo no MCT \\
\hline \multicolumn{3}{|c|}{2005} \\
\hline $28 / 11$ & Conferência começa sem clima no Canadá & Conferência começa sem clima no Canadá \\
\hline $28 / 11$ & $\begin{array}{l}\text { Em seu } 2^{\circ} \text { ataque, sonda japonesa } \\
\text { consegue coletar solo de asteroide }\end{array}$ & $\begin{array}{l}\text { Em seu } 2^{\circ} \text { ataque, sonda japonesa consegue } \\
\text { coletar solo de asteroide }\end{array}$ \\
\hline \multicolumn{3}{|c|}{2006} \\
\hline $10 / 11$ & $\begin{array}{l}\text { Cérebro humano herdou gene neandertal, } \\
\text { diz estudo }\end{array}$ & $\begin{array}{l}\text { Cérebro humano herdou gene neandertal, diz } \\
\text { estudo }\end{array}$ \\
\hline $10 / 11$ & $\begin{array}{l}\text { Primo "bruto" da humanidade também } \\
\text { tinha dieta variada }\end{array}$ & $\begin{array}{l}\text { Primo "bruto" da humanidade também tinha } \\
\text { dieta variada }\end{array}$ \\
\hline
\end{tabular}




\begin{tabular}{|l|l|l|}
\hline \multicolumn{2}{|l|}{2007} \\
\hline $15 / 11$ & $\begin{array}{l}\text { Físicos brasileiros conseguem "despir" } \\
\text { buraco negro }\end{array}$ & $\begin{array}{l}\text { Físicos brasileiros conseguem "despir" buraco } \\
\text { negro }\end{array}$ \\
\hline $15 / 11$ & $\begin{array}{l}\text { Clonagem terapêutica não é realista, diz } \\
\text { "pai" de Dolly }\end{array}$ & Terapia não é realista, diz "pai" de Dolly \\
\hline \multicolumn{2}{|c|}{$\mathbf{2 0 0 8}$} \\
\hline $14 / 11$ & Baratas têm estratégia para rota de fuga & Baratas têm estratégia para rota de fuga \\
\hline $14 / 11$ & $\begin{array}{l}\text { Astrônomos fazem } 1^{\text {a }} \text { foto de um sistema } \\
\text { extra-solar }\end{array}$ & $\begin{array}{l}\text { Astrônomos fazem 1 }{ }^{\text {a }} \text { foto de um sistema extra- } \\
\text { solar }\end{array}$ \\
\hline $14 / 11$ & Sonda enviada pela Índia pousa na Lua & Sonda enviada pela Índia pousa na Lua \\
\hline
\end{tabular}

\subsection{Aspectos fundamentais para a elaboração de uma análise dialógica: coerções e elementos constitutivos do gênero discursivo}

De acordo com a disciplina Metalinguística formulada por Bakhtin, nossa análise buscou as relações dialógicas hipertextuais, tomando as reportagens que compõem corpus sob o ponto de vista do gênero discursivo, bem como das esferas em que os enunciados em questão emergem. Sabemos que os gêneros são tipos relativamente estáveis de enunciados que possuem três elementos constitutivos, o estilo, a forma composicional e o conteúdo temático e que os enunciados moldados em determinado gênero sofrem coerções das esferas da atividade humana de onde se originam. No âmbito de suas respectivas esferas, os gêneros discursivos refletem e refratam a própria realidade.

Conforme detalhamos anteriormente, os enunciados selecionados em nossa tese emergem essencialmente na fronteira entre duas esferas, a jornalística e a científica. No entanto, é na esfera jornalística que ocorre a circulação dos enunciados cujo conteúdo temático vem a refletir, de modo aparente, a relevância dos avanços da ciência e sua aplicabilidade para toda a sociedade, e de modo menos evidente, aspectos políticos escamoteados pelos interesses científicos. A forma composicional e o estilo estão estritamente relacionados com a esfera jornalística e aproximam-se dos procedimentos previstos nos manuais e da prática jornalística. Além da natureza de maior acessibilidade e clareza do texto jornalístico, as reportagens de ciência acumulam a função de didaticidade. A seguir, vejamos o detalhamento das características de cada um desses elementos. 


\subsubsection{Forma composicional, hiperestrutura e hipertexto}

A forma composicional foi o ponto de partida para a análise, uma vez que os primeiros aspectos analisados foram a hiperestrutura e ao hipertexto. Antes de discorrermos sobre tais noções, faz-se necessário compreender de que maneira a forma composicional é elaborada no âmbito na obra de Bakhtin e seu Círculo. Podemos dizer que o conceito de composicionalidade aparece por meio de duas orientações distintas em toda a obra do Círculo. A primeira definição de forma composicional é desenvolvida a partir da noção de forma arquitetônica, enquanto a segunda visa situar a forma composicional como um dos elementos constitutivos do gênero discursivo.

Partindo da primeira orientação, temos que a noção de forma arquitetônica começa a ser elaborada em uma das primeiras obras atribuídas a Bakhtin, Por uma filosofia do ato (1924), mas é devidamente expandida no texto O problema do conteúdo, do material e da forma (1923-24). Nesse último, o conceito de forma composicional aparece na contraposição com a noção de forma arquitetônica. Enquanto esta toma os valores morais e físicos do homem estético e da natureza, aquela se refere ao objeto estético realizado da forma arquitetônica. $\mathrm{O}$ aparecimento de tal contraposição constitui-se como uma das críticas de Bakhtin à Estética Material e ao método formalista aplicado à obra artística. A forma arquitetônica determina a organização do material concretizado na forma composicional, não devendo ser confundida com a própria forma composicional. Portanto, uma análise estética deve se perguntar: de que maneira a forma composicional (organização do material) realiza uma forma arquitetônica (a unificação dos valores e a organização dos valores cognitivos e éticos)?

Já em The formal method in literary scholarship (1928), os autores passam a pensar na forma composicional e sua relação com outra noção, a de tematicidade. Ampliando a discussão crítica a respeito do método formal, no sétimo capítulo, os autores citam a diferença entre a finalização composicional da finalização temática. A composicionalidade possui um fim na própria esfera, mas o tema não. A crítica baseia-se no fato de que os formalistas centraram-se nas questões de ordem composicional, não levando em consideração os aspectos temáticos.

Finalmente na obra de 1952-53, especificamente no texto Os gêneros do discurso, a forma composicional diz respeito ao tipo de estruturação que um enunciado assume de acordo com o gênero ao qual pertence. A forma composicional está ligada a uma "forma padrão e relativamente estável de estruturação de um todo”, segundo Bakhtin (1952-53/2003: 
301) e pode ser considerado o elemento mais característico do gênero. Enquanto o objeto estético dotado de sentido é criado no nível arquitetônico, a forma composicional se integra a ele de maneira constitutiva. Segundo Sobral (2005b), a forma composicional "é o modo específico de estruturação da obra externa a partir de sua concepção arquitetônica” (p.112).

A comparação entre reportagens da FSP e da FO levou-nos a uma reflexão sobre a forma arquitetônica do gênero reportagem de modalidade escrita impressa e digital. Na FSP, as reportagens apresentam-se mais fragmentadas, constituindo-se a partir de um enunciado ou um conjunto deles. Tal observação só pode ser feita a partir da análise inicial dos enunciados digitais. De acordo com o que apontamos na seção anterior, enunciados que compunham a reportagem na FO eram autônomos e nem sempre possuíam relações dialógicas hipertextuais que evidenciassem o diálogo entre eles.

Passamos a compreender que, ao passo em que as reportagens da FO são compostas por um único enunciado que podem ou não estabelecer algum tipo de relação remissiva hipertextual com outros enunciados, a FSP comporta reportagens que no plano da composição arquitetônica prevê a concretização de diferentes pontos de vistas sobre um mesmo acontecimento a partir de um ou mais enunciados. Nos casos em que a reportagem é composta por mais de um enunciado, há sempre um dominante - enunciado fonte - que, espacialmente, ocupa uma porção maior na estrutura da forma organizacional da reportagem.

Sendo a forma composicional uma das categorias selecionadas e previstas no projeto de pesquisa para o desenvolvimento da análise das relações hipertextuais, destacamos suas principais características encontradas no corpus: (1) a estrutura fragmentada ou hiperestrutura (Adam \& Lugrin 2001) formada a partir de diferentes planos de concretização do enunciado; (2) os mecanismos de articulação e remissão de enunciados presentes no hipertexto, também denominados links, mas que tomaremos pelo termo "nós remissivos"; e (3) as diferentes dimensões do enunciado que retratamos anteriormente, verbal e verbovisual - a última podendo ser composta por fotografias, infográficos, esquemas ilustrativos ou explicativos e mapas.

Em convergência com a ideia de que a forma arquitetônica da reportagem impressa prevê a concretização de um conjunto de enunciados ou de um mesmo enunciado fragmentado no nível da forma composicional, recorremos à noção de hiperestrutura desenvolvida por autores como Gilles Lugrin e Jean-Michel Adam que também observam esse modo de estruturação em seus estudos. De acordo com Lugrin (2001), a hiperestrutura é um elemento de estruturação da informação situada entre o veículo, no caso o jornal em sua versão impressa e digital, e seus enunciados, as reportagens de DC selecionadas para análise, 
que surge de um processo de fragmentação ou agrupamento formado por elementos verbais e verbo-visuais. As principais tendências acarretadas pela evolução da hiperestrutura repercutem na leitura esporádica de textos múltiplos organizados em pequenos módulos (mosaicos) e no desenvolvimento visual do layout da publicação, assim como ocorre na FSP. Entretanto, a elaboração da estruturação da informação difere de acordo com cada meio e publicação, um dos fenômenos que se pretende descrever nesta pesquisa.

Outro fator que será discutido resvala na questão do impacto do leitor presumido na forma composicional dos gêneros reportagem em meio impresso e digital. De acordo com Lugrin (2001), a imprensa cujo leitor presumido é mais especializado, como a revista Pesquisa FAPESP, utiliza textos lineares e elementos infográficos mais simples, enquanto a imprensa popular, tal como os jornais de grande circulação, vale-se da hiperestrutura na composição e apresentação de seus enunciados. Neste caso, interessa-nos delinear o perfil do leitor presumido tanto da FO e quanto da FSP, bem como elencar as semelhanças e diferenças encontradas nas duas publicações de acordo com esse quesito. O leitor presumido também será depreendido da análise das peças publicitárias dispostas na hiperestrutura do jornal impresso.

Os diferentes enunciados distribuídos na página impressa fragmentada, geralmente, estabelecem uma relação dialógica entre si. A partir de tal característica da forma composicional, depreende-se que o leitor presumido da FSP é parte de um grupo mais heterogêneo, fato que é refletido pela escolha dos diferentes desdobramentos do acontecimento fonte que pertence à esfera científica. Logo, a construção composicional oferecida pela hiperestrutura torna-se mais interessante não somente no ato de captar o público alvo e tornar a publicação mais vendável, mas também por potencializar o caráter informativo da reportagem, fragmentando pontos-de-vista em blocos menores e compactos.

O emprego da hiperestrutura favorece a redução do tamanho dos enunciados veiculados, propicia a leitura seletiva em mosaico, bem como contribui para o maior desenvolvimento visual do layout da página. Segundo Lugrin (2001), a função primordial deste tipo de estruturação é a de marcar diferentes instâncias ou posições enunciativas e ideológicas, uma vez que a circulação do sentido é interior à hiperestrutura. As unidades enunciativas mais autônomas marcam diferentes posicionamentos e possibilitam um diálogo mais explícito entre as diferentes vozes delimitadas em cada pequeno texto.

A maioria dos estudos sobre a hiperestrutura está voltada para a análise do jornal impresso. No entanto, interessa-nos saber se há alguma relação no modo de organização dos enunciados do jornal impresso com a forma composicional dos enunciados do jornal digital. 
De acordo com Lugrin (2001), os jornais de grande circulação no mundo inteiro sentiram a necessidade de disponibilizar uma versão online de suas publicações. O autor acrescenta que o desenvolvimento da hiperestrutura em meio impresso é paralelo ao advento das tecnologias digitais.

A organização dos enunciados em hiperestrutura, apontada como uma evolução por Adam \& Lugrin (2006), pode ser encontrada de duas formas. O primeiro tipo de hiperestrutura equivale ao desmembramento de um texto em módulos que formam novas unidades. O segundo tipo é constituído de textos de fontes diferentes, mas que são complementares entre si, em que o tópico enunciativo é reorganizado de acordo com a esfera da atividade humana com a qual aquele determinado enunciado dialoga. Por exemplo, a análise da reportagem que tratou do rebaixamento do planeta Plutão a planeta-anão (Grillo \& Ferraz 2009) apresentou uma hiperestrutura do segundo tipo ao apresentar enunciados vinculados que dialogavam com outras esferas da atividade humana, tal como a pedagógica, a política e a científica.

A relação de subordinação ou complementaridade entre os enunciados, emprestando os termos de Adam \& Lugrin (2006), pode ser entendida como um tipo de relação dialógica hipertextual não marcada. Isto é, não há nenhum nó aparente que leve o leitor de um módulo textual a outro, como ocorre com o nó eletrônico na publicação online. Por exemplo, ao verificar dois enunciados que compõem a mesma reportagem da FSP na FO, vemos que as duas reportagens também estão relacionadas, não de forma modular, mas por meio de nós remissivos. A hierarquia da relação de subordinação estabelecida no jornal impresso não é sempre recuperada no jornal digital, como observamos nos exemplos das figuras (4) e (5). 
Figura (4) - “Área quilombola 'inviabiliza' programa espacial”, reportagem publicada na FSP

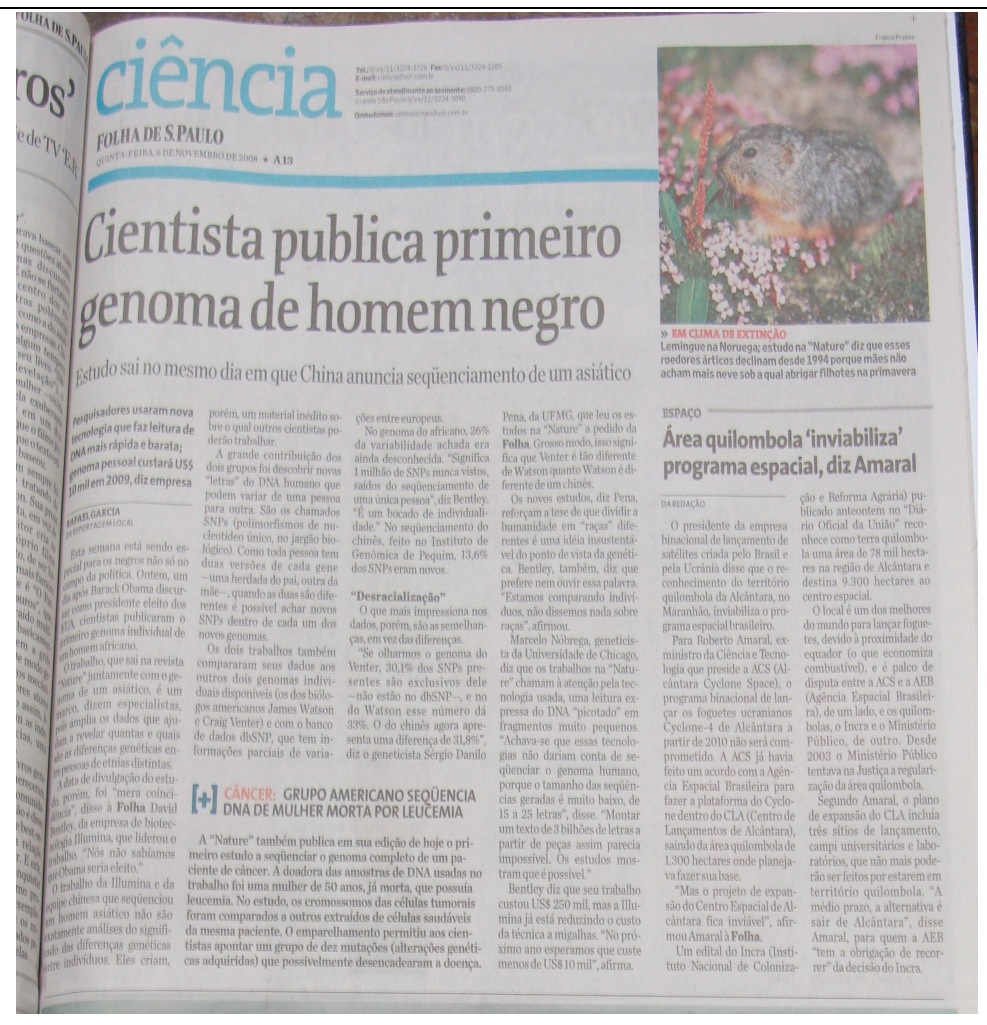

Figura (5) - “Área quilombola 'inviabiliza’ programa espacial”, reportagem publicada na FO

\section{Área quilombola "inviabiliza" programa espacial, diz Amaral}

da Folha de S.Paulo

\author{
爪'\} Recomendar \\ f Seja o primeiro de seus amigos a recomendar isso.
}

O presidente da empresa binacional de lançamento de satélites criada pelo Brasil e pela Ucrânia disse que o reconhecimento do território quilombola da Alcântara, no Maranhäo, inviabiliza o programa espacial brasileiro.

Para Roberto Amaral, ex-ministro da Clência e Tecnologia que preside a ACS Cyclone-4 de Alcântara a partir de 2010 näo será comprometido.

A ACS já havia feito um acordo com a Agência Espacial Brasileira para fazer a Alacta forma do Cyclone dentro do CLA (Centro de Lançamentos de Alcântara), saindo da área quilombola de 1.300 hectares onde planejava fazer sua base.

"Mas o projeto de expansäo do Centro Espacial de Alcântara fica inviável", afirmou Amaral à Folha.

Um edital do Incra (Instituto Nacional de Colonização e Reforma Agrária) publicado na terça-feira (4) no "Diário Oficial da Uniäo" reconhece como terra quilombola uma área de 78 mil hectares na regiăo de Alcântara e destina 9.300 hectares ao centro espacial.

o local é um dos melhores do mundo para lançar foguetes, devido à proximidade do equador (o que economiza combustivel), e é palco de disputa entre a ACS e a AEB (Agêncla Espacial Brasileira), de um lado, e os quilombolas, o Incra e o Ministério Público, de outro. Desde 2003 o Ministério Público tentava na Justiça a regularizaçăo da área quilombola.

Segundo Amaral, o plano de expansäo do CLA incluía três sítios de lançamento, campi universitários e laboratórios, que näo mais poderäo ser feitos por estarem em território quilombola. "A médio prazo, a alternativa é sair de Alcântara", disse Amaral, para quem a AEB "tem a obrigação de recorrer" da decisäo do Incra. (Alcåntara Cyclone Space), o programa binacional de lançar os foguetes ucranianos

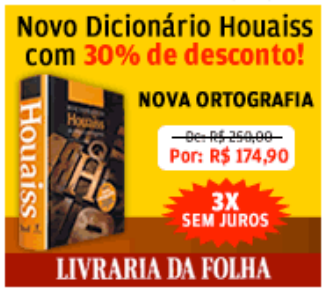

\begin{tabular}{l}
\hline LEIA MAIS \\
$: \frac{\text { Rússia e França vão ajudar Brasil em projeto de satélite }}{\text { Inpe prepara micros satélites para coletar dados ambientais }}$ \\
$: \frac{\text { Aeronáutica testa motor do foquete VLS-1 com sucesso }}{\text { Turista espacial quer comprar terreno na Lua }}$ \\
\hline ESPECIAL \\
\hline - Leia o que iá foi publicado sobre satélite \\
Neveque no melhor roteiro de cultura e diversäo da internet
\end{tabular}


$\mathrm{Na}$ figura (4), o enunciado da reportagem principal da FSP que discorre sobre descobertas envolvendo o genoma do homem negro está relacionado ao segundo texto que, por sua vez, aborda a inviabilização de um projeto espacial em uma área quilombola. Sob o ponto de vista da área científica mobilizada, os enunciados divergem. O primeiro pertence ao escopo da genética, enquanto o segundo está relacionado à cosmologia. No entanto, ambos apresentam em comum a menção ao homem negro refletido e refratado em dois acontecimentos da esfera científica.

$\mathrm{Na} \mathrm{FO}$, a relação entre os enunciados é diferente daquela observada no último exemplo. Por meio da figura (5), notamos que o texto que trata sobre a implementação do programa espacial em área quilombola não se relaciona com o mesmo enunciado do jornal impresso, mas sim a outros enunciados cujo assunto volta-se para a corrida espacial e eventos relacionados, por meio dos nós eletrônicos situados ao final da reportagem.

A forma composicional encontrada nos enunciados da FSP, em geral, constrói-se como um conjunto de enunciados menores fragmentados enquanto a hiperestrutura da FO tende a ser mais fragmentada na página inicial da seção e menos fragmentada na página em que se apresenta o enunciado. Na publicação impressa, as reportagens de DC são veiculadas na seção Folha Ciência que, geralmente, é uma editoria que ocupa uma página do primeiro caderno do jornal. As reportagens compartilham o espaço da página com anúncios publicitários, notas, pequenas notícias, fotos e esquemas ilustrativos.

A seção Folha Ciência em versão impressa é composta por um número bastante limitado de reportagens que, geralmente, tratam de descobertas científicas e tecnológicas, assuntos da esfera científica com repercussão internacional naquele período ou que estão relacionados a questões políticas. Na FO, as reportagens de DC são concentradas na seção Ciência, diferente em diversos aspectos da seção do jornal impresso, sobretudo, quanto à capacidade de armazenamento das reportagens anteriores e ao espaço o qual permite que em um único dia sejam publicadas inúmeras reportagens. Além disso, a seção comporta uma maior diversidade de gêneros discursivos, tal como enquetes, colunas, entrevistas, entre outros, e ainda divide espaço com diversos anúncios publicitários, como podemos notar na reprodução da página inicial da FO na figura (6) a seguir: 
Figura (6) Reprodução da página inicial da seção Ciência da FO

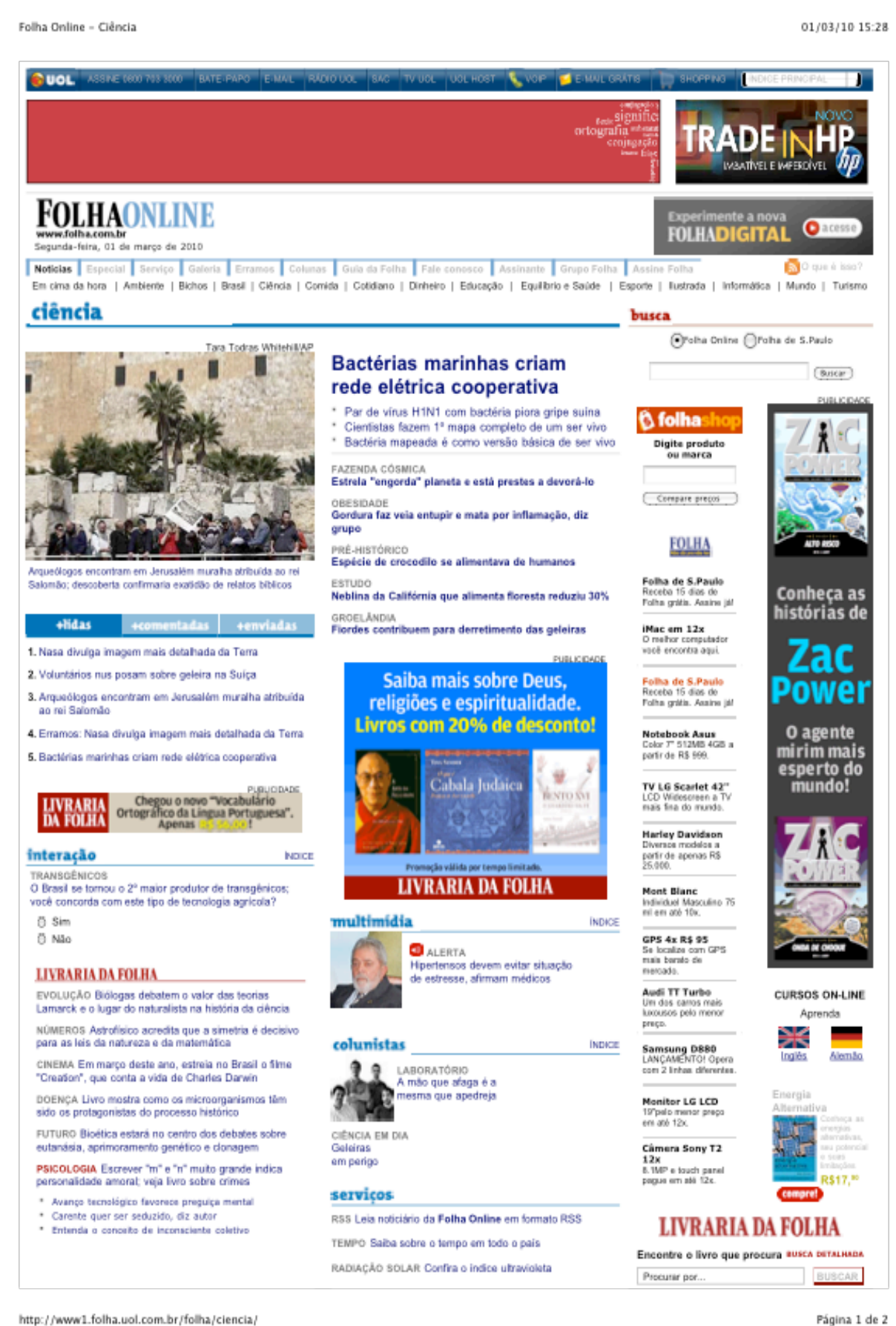

As reportagens da $\mathrm{FO}$ estão presentes em duas páginas distintas. A primeira é a página principal da seção Ciência que funciona como um sumário, trazendo somente os títulos e chamadas paras as reportagens e outros enunciados, como mostrou a figura (6). Ao selecionar e clicar em um dos títulos presentes no sumário da página principal, o leitor é 
levado a uma nova página e, dessa forma, poderá obter acesso à reportagem. Nesse momento, o enunciado participa de outro plano hiperestrutural como mostrado na figura (7):

Figura (7) Reprodução de reportagem da FO

\begin{tabular}{|c|c|c|}
\hline \multicolumn{3}{|l|}{$\begin{array}{l}\text { Berlim, Londres, Buenos Aires e São Paulo: } \\
\text { embarque no roteiro de luxo de Danuza Leão! } \\
\text { UVRARIA DA FoLHA }\end{array}$} \\
\hline \multicolumn{3}{|c|}{ 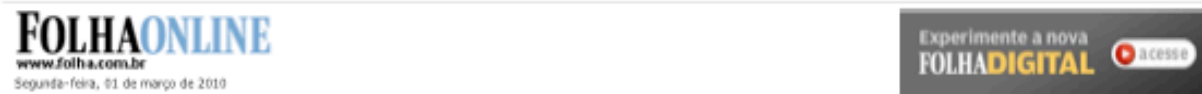 } \\
\hline \multicolumn{3}{|c|}{  } \\
\hline G & \multicolumn{2}{|c|}{ 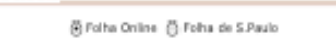 } \\
\hline \multicolumn{3}{|l|}{$\begin{array}{l}\text { Gordura faz veia entupir e mata por inflamação, diz grupo } \\
\text { Gordura } 12210\end{array}$} \\
\hline $\begin{array}{l}\text { REINaLDo josk Lopes } \\
\text { do Folha de S. Pads }\end{array}$ & \multicolumn{2}{|c|}{ thidas |ceomentadns tenviadrs } \\
\hline $\begin{array}{l}\text { Pessoss obesss tèm probiemas de saúde que vâo multo alim do excesso de } \\
\text { peso, solrendo com disbetes e sintomas cardiovosculares. }\end{array}$ & \multicolumn{2}{|c|}{ 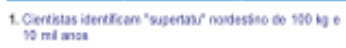 } \\
\hline 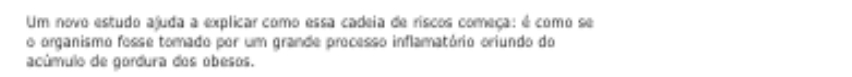 & \multicolumn{2}{|c|}{ 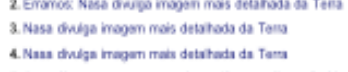 } \\
\hline \multicolumn{3}{|l|}{ 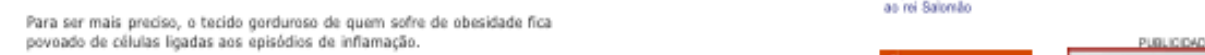 } \\
\hline 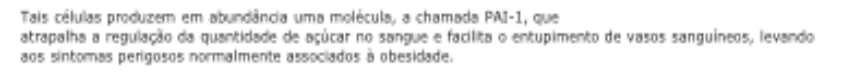 & $\begin{array}{l}\text { (5) folhashos: } \\
\text { Digite protuto } \\
\text { ou marca }\end{array}$ & \\
\hline 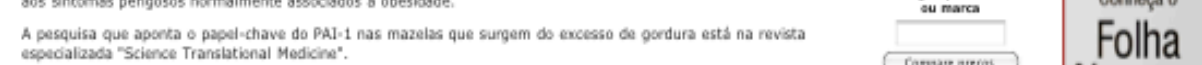 & Corgaregrees & \\
\hline \multirow{2}{*}{ 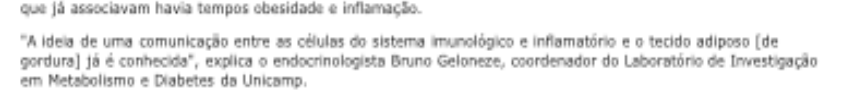 } & 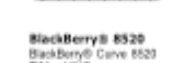 & \\
\hline & TME WNa & \\
\hline Latocis de ArtelfFolhs Imagem & 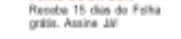 & \\
\hline \multicolumn{3}{|l|}{ Lado a lado } \\
\hline 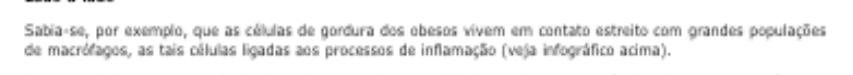 & 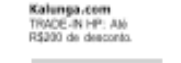 & \\
\hline 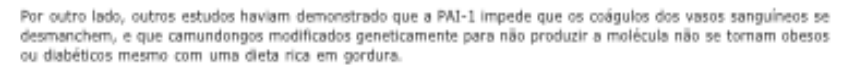 & 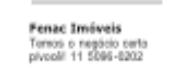 & \\
\hline 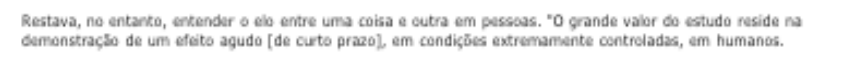 & 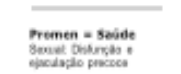 & \\
\hline $\begin{array}{l}\text { A imensa maiofis dos testes sempre foi conduzida em modelos animais, como camundengos e ratos", dizo } \\
\text { pesequisador da Unicamp. }\end{array}$ & & \\
\hline  & 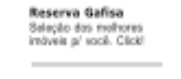 & \\
\hline 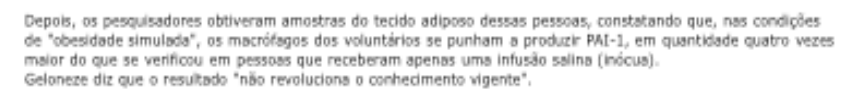 & 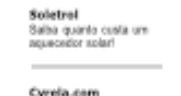 & \\
\hline 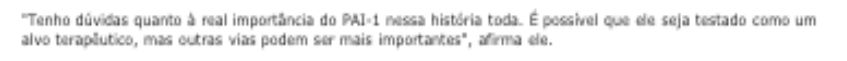 & 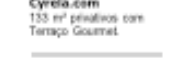 & \\
\hline  & 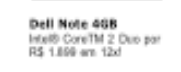 & \\
\hline 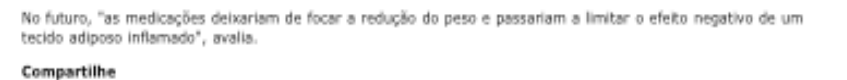 &  & \\
\hline 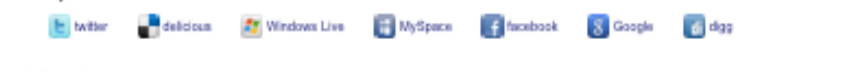 &  & \\
\hline Leis mais & & \\
\hline 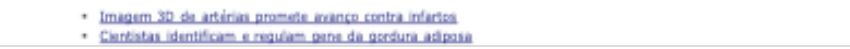 & 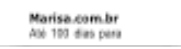 & Racus? \\
\hline
\end{tabular}


Neste caso, a reportagem ocupa a maior parte do espaço dedicado à página juntamente com algumas peças publicitárias, o cabeçalho do jornal online e algumas indicações de outras reportagens ou artigos cujos títulos estão sob forma de nó eletrônico. As páginas do jornal online são mais fragmentadas e possuem uma quantidade maior de informações a serem consultadas, facilidade gerada pela tecnologia de armazenamento da informação e remissão de um enunciado a outro.

A hiperestrutura como elemento previsto na forma composicional das reportagens de DC da FSP e da FO podem ser representadas da seguinte forma:

Gráfico (3): Representação da hiperestrutura em páginas da FSP e da FO, respectivamente ${ }^{50}$.
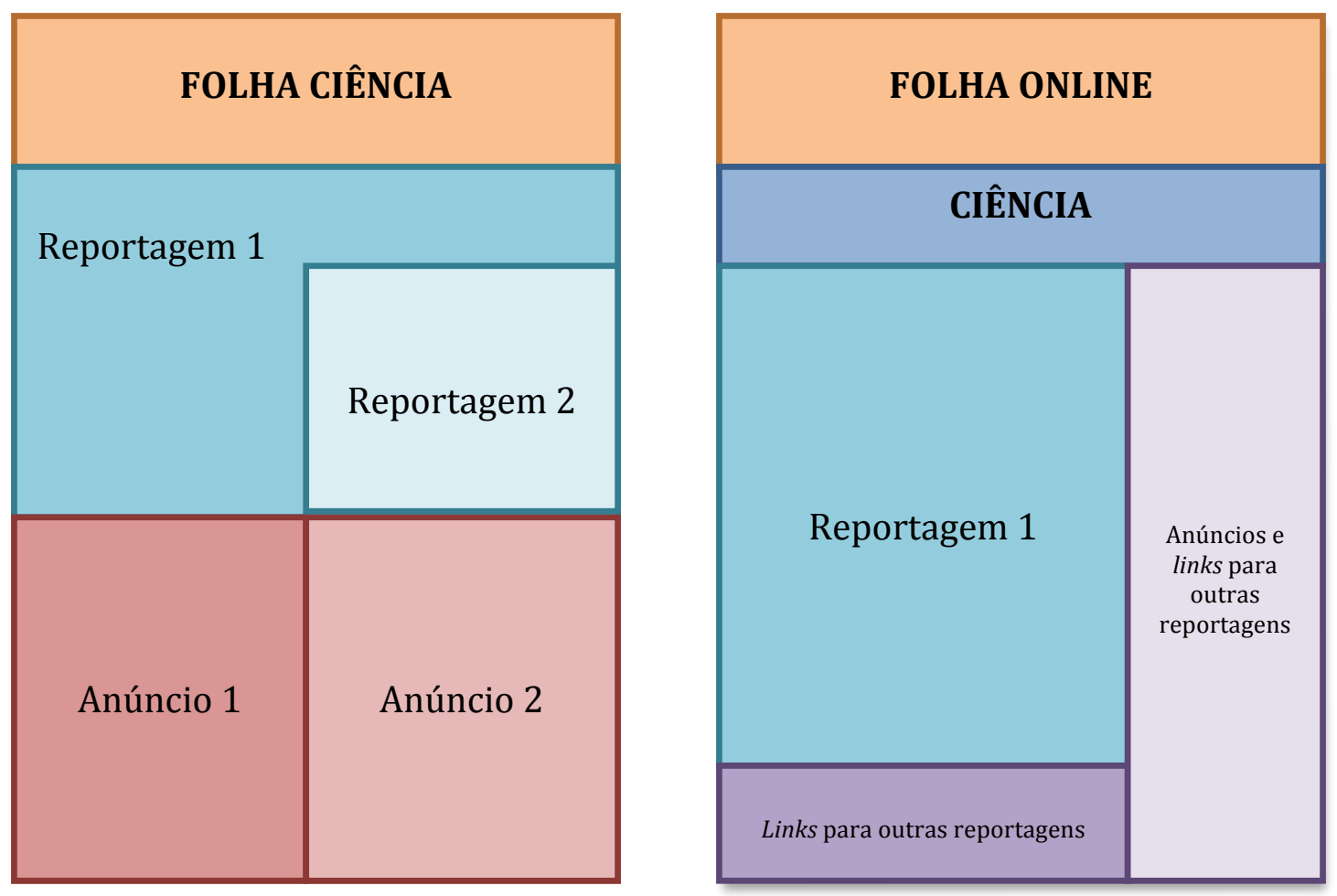

A hiperestrutura das páginas do jornal online não poderá ser recuperada devido à atualização constante das reportagens publicadas. Toda vez que uma reportagem antiga é acessada, a hiperestrutura da página em que está situada traz os dados do dia, como a data, links para as reportagens atuais, ou seja, as informações da hiperestrutura que constavam no dia da publicação da reportagem não podem mais ser acessadas. Logo, a hiperestrutura que

\footnotetext{
${ }^{50}$ A elaboração dos gráficos em (3) baseou-se nas reportagens publicadas em 28 de novembro de 2005 cuja análise foi desenvolvida no capítulo 4 .
} 
emoldura as reportagens digitais a serem analisadas não é compatível sob o ponto de vista cronológico.

Esse fato não favorece uma análise da hiperestrutura das reportagens do jornal digital, apenas da publicação impressa, mas não prejudica a análise comparativa entre os dois jornais, o que certamente trará evidências de como a hiperestrutura pode ou não contribuir para a presença da hipertextualidade entre as reportagens. Por isso, na análise colocamos em primeiro plano as reportagens impressas e as páginas da FSP e, ao final de cada bloco de reportagens analisadas, procuramos saber se as mesmas relações dialógicas hipertextuais foram estabelecidas no jornal online e se podem ou não ser recuperadas.

Após a análise da hiperestrutura, a segunda categoria a ser analisada é o hipertexto, aspecto já contemplado no primeiro capítulo desta tese, momento em que fizemos a sua relação com a teoria dialógica do discurso. Retomando a definição de Lévy (1999), temos:

\footnotetext{
Uma formação não-linear de apresentar e consultar informações. Um hipertexto vincula as informações contidas em seus documentos (ou "hiperdocumentos", como preferem alguns) criando uma rede de associações complexas através de hyperlinks ou, mais simplesmente, links. (p.254)
}

Logo, assumimos a condição de que um hipertexto constitui-se como parte de uma formação não linear que vincula informações por meio de mecanismos de remissão ou de associação complexa, tal como aponta Lévy (1999). No entanto, consideramos que tais mecanismos incorporam as características da tecnologia na qual interferem. No caso do hipertexto em meio digital, a articulação dos enunciados é travada, principalmente, por meio do nó eletrônico. Já em um documento impresso, tal relação entre enunciados geralmente ocorre mediante sinalizadores ou diferentes símbolos que apontam para o exterior daquele enunciado, daquela página ou, até mesmo, daquele veículo.

Todo enunciado que apresentar um elemento de remissão a outro enunciado, constituindo assim uma relação dialógica hipertextual, será considerado um hipertexto. $\mathrm{O}$ que difere um do outro é o mecanismo de remissão que é favorecido pela tecnologia digital, no caso específico dos nós eletrônicos. No entanto, notamos o aparecimento da representação de nós eletrônicos na FSP, assim como outros tipos de mecanismos que independem da articulação instantânea propiciada pelo hiperlink, como no caso de notas de rodapé ou índices. Os diferentes modos de remissão hipertextual por meio de links são alvo de interesse para o desenvolvimento de nossa análise. 


\subsubsection{Dimensão verbo-visual do enunciado}

Além de aspectos da forma composicional propiciarem a hipertextualidade no enunciado, consideramos que os elementos gráficos e visuais, aliados aos elementos verbais, também podem funcionar como um canal de remissão de um enunciado a outro. Tal como nos explica Machado (2011), a inserção de elementos gráficos torna possível a apreensão de conceitos complexos que não seriam facilmente explicados ou exemplificados por meio de outros sistemas semióticos. Segundo a autora, "a infografia é a grande imaginação científica hoje" (Machado, 2011, p.234) e acrescenta:

É no jornal e nas revistas que a ciência encontrou lugar especial de divulgação e é nessas publicações impressas que a infografia conheceu um desenvolvimento surpreendente, introduzindo uma prática de criação de notícias totalmente contaminada pela imagem eletrônica. (Machado, 2011, p.234)

Uma vez que a infografia resulta da conjugação de diferentes sistemas semióticos, sua relação com os demais enunciados da reportagem são de extrema relevância para nossa análise. Logo, buscando teorizações inspiradas na teoria bakhtiniana, a dimensão verbovisual dos enunciados será levada em consideração com base nos estudos recentes de Brait (2009) e Grillo (2009), com vistas à análise das ilustrações-síntese, esquemas ilustrativos, fotos e demais elementos do peritexto ${ }^{51}$ que compõem os enunciados.

Partiremos da definição de Brait (2009, p. 143) de que a verbo-visualidade é constituída igualmente do componente verbal e visual, "impossibilitando o tratamento excludente [de um ou outro] e, em especial, das formas de junção assumidas por essas dimensões para produzir sentido". A autora também atenta para a relação entre os enunciados verbo-visuais com a sua esfera de produção ou circulação, sobretudo a esfera jornalística:

\footnotetext{
${ }^{51} \mathrm{O}$ peritexto corresponde a todos os elementos circundantes do texto, tal como títulos e subtítulos, que compõem a dimensão verbovisual do enunciado.
} 
$\mathrm{Na}$ esfera jornalística, por exemplo, o projeto discursivo é constitutivamente verbovisual, ainda que se considere apenas o jornalismo impresso. Essa marca identitária pode ser constatada na abundância de desenhos, ilustrações, gráficos e infográficos, cujas presenças implicam textos verbais com os quais a dimensão visual está geneticamente articulada, e, também, na forma singular de disposição das matérias numa página, num determinado caderno. $\mathrm{O}$ diálogo entre diferentes textos constroi sentidos por meio das especificidades da dimensão verbovisual. (BRAIT, 2009, p. 143)

Por meio das observações iniciais a respeito da dimensão verbo-visual dos enunciados, constatamos que o aproveitamento dos recursos infográficos e de elementos verbo-visuais é muito maior em enunciados impressos. Apesar de o meio digital poder articular diferentes tipos de interface, sua característica multimodal não possui grande aproveitamento nas reportagens de ciência da FO. Ao contrário, os esquemas ilustrativos e imagens são amplamente utilizados em reportagens impressas.

Sobre a incidência de elementos gráficos em reportagens de ciência, Machado (2011) relata que:

O texto científico nunca prescindiu das classes de signos gráficos da visualidade que foram, no decorrer da história da cultura, aprimorados pelos meios impressos, científicos, digitais. A divulgação científica por meio das diferentes práticas do jornalismo não apenas tornou efetiva tal possibilidade como também redimensionou as configurações gráficas para representar argumentos. (Machado, 2011, p.16)

Ao longo de sua tese de livre-docência, a autora defende a ideia da argumentação gráfica como uma forma de pensamento, não se limitando ao enunciado verbal, mas abordando também na dimensão visual. Os ensaios gráficos, segundo Machado (2011), situam visualmente os conteúdos de pesquisas em desenvolvimento, no caso de suas análises. Tomaremos alguns pressupostos encontrados em Machado (2011), tal como a função do infográfico e sua relação com os demais elementos da reportagem, para o desenrolar de nossa análise.

Em sua análise sobre enunciados verbo-visuais em reportagens de capa da revista Pesquisa Fapesp, Grillo (2009) propõe a análise das relações dialógicas entre os planos de expressão verbal e visual e contribui para o desenvolvimento do nosso dispositivo analítico. Sua análise objetiva: 
identificar o diálogo entre os planos de expressão verbal e visual, respeitando as especificidades na produção de sentidos de cada plano semiótico, a fim de descrever as regularidades no gênero reportagem de divulgação científica em uma de suas esferas de produção, circulação e recepção. (Grillo, 2009, p. 218).

Não somente análises de cunho dialógico interessam-se pela conjunção de mais de um sistema semiótico, ou pelas peculiaridades de cada um deles. A semiótica proposta pela Escola de Paris interessa-se pelo que denomina sincretismo quando há a injunção de elementos discrepantes do ponto de vista do plano da expressão para a geração de novos elementos no plano do conteúdo, como observamos nas obras de Pietroforte (2010 e 2011) que, por sua vez, baseia-se na obra de Jean-Marie Floch (1995).

Entretanto, as relações semântico-axiológicas que buscamos, ao contrário do percurso gerativo do sentido previsto pelo quadrado semiótico e a da análise das diversas imagens geradas por uma só imagem ou pela combinação de outras plasticidades, contemplam a exterioridade. Sendo parte constitutiva do enunciado do qual faz parte, sob a perspectiva da teoria dialógica do discurso, os elementos verbo-visuais também estão ancorados na historicidade e no contexto social que envolveram a sua concretização.

\subsubsection{Estilo, projeto editorial e Manual da Redação do Grupo Folha}

Ao discorrer sobre o estilo, Bakhtin (2003 [1952-53]) refere-se tanto ao estilo do autor e sua individualidade, bem como o estilo próprio do gênero discursivo: "Em cada campo existem e são empregados gêneros que correspondem às condições específicas de dado campo; é a esses gêneros que correspondem determinados estilos", (Bakhtin, 2003 [1952-53], p. 266). A respeito do estilo do gênero reportagem de DC, notamos (Ferraz 2007) que este é menos suscetível ao aparecimento do estilo individual do autor e favorece o aparecimento de links eletrônicos na forma composicional. Com o 'apagamento' das marcas do estilo do autor, a reportagem visa a um grau de maior informatividade e objetividade em relação aos fatos tratados, conforme discorremos ao descrever as características constitutivas do gênero reportagem de DC em seções anteriores. A sua composição fragmentada e a possibilidade em se agrupar enunciados em uma mesma reportagem favorece diferentes análises sobre o mesmo fato ao leitor e o discurso, no caso o de DC, pode ser atravessado por discursos provenientes também de outras esferas, tais como a política e a pedagógica. 
Motivados pelas mudanças estilísticas, bem como composicionais, observadas na composição das páginas das reportagens impressas, e considerando a diacronicidade do corpus, recorremos ao Manual da Redação elaborado pelo Grupo Folha para a padronização das práticas linguísticas e jornalísticas em todos os seus segmentos ${ }^{52}$. Tratando-se de uma tese que se desenvolve a partir de enunciados de meios diferentes, uma análise comparativa torna-se inevitável e análise descritiva prévia do corpus já comprovou que o advento da tecnologia digital incide sobre a publicação impressa de forma mais incisiva a cada ano.

Logo, a expectativa ao consultar o Manual era o de encontrar os indícios, diretamente na esfera de produção dos enunciados concretos que analisamos, da mútua influência entre impresso e digital. Tais mudanças observadas na FSP, como a maior fragmentação das reportagens impressas e a inserção de esquemas explicativos complexos, seriam motivadas por uma orientação editorial específica? Há algum tipo de recomendação direcionada para a FO? Qual o critério de seleção de reportagens em ambos os meios?

A leitura do Manual possibilitou-nos o acesso ao projeto editorial da Folha, aos procedimentos sugeridos aos jornalistas e à padronização do estilo com "recomendações para escrever um texto claro" (p.51). Também pudemos averiguar que o primeiro projeto editorial da FSP data de 1984, seguido por mais dois, respectivamente, de 1987 e 1997. O projeto editorial atual é o mesmo de 1997, com algumas reformulações e está em sua $16^{\text {a }}$ edição. Apesar de ter sofrido alterações, não observamos dados significantes sobre a publicação digital, FO, muito menos no que tange ao advento da internet. Sobre a tecnologia digital, o Manual limita-se a afirmar que:

\begin{abstract}
Em meio à balbúrdia informativa, a utilidade dos jornais crescerá se eles conseguirem não apenas organizar a informação inespecífica, aquela que potencialmente interessa a toda pessoa alfabetizada, como também torná-la mais compreensível em seus nexos e articulações, exatamente para garantir seu trânsito em meio à heterogeneidade de um público fragmentário e dispersivo. (Manual da Redação, 2010, p. 15)
\end{abstract}

Entretanto, o manual escrito em 1997 já previa a influência do aumento da acessibilidade a informações sobre os leitores e demonstra uma preocupação quanto à redefinição da função do jornal impresso: a de levar a uma reflexão mais aprofundada ao deparar-se com uma seleção de notícias, artigos e reportagens que atendam às demandas

\footnotetext{
${ }^{52}$ No entanto, o Manual da Redação é vendido para o grande público e pode ser encontrado em quaisquer livrarias.
} 
sociais. No que tange à esfera de produção, encontramos dados sobre a constituição do jornal impresso, mas nada sobre o processo da FO que acaba aproveitando os textos das reportagens da FSP. No que diz respeito às reportagens, encontramos uma série de procedimentos direcionados ao jornalista-autor que elencamos em seguida:

- a contextualização "presumindo que quem irá ler o texto é um grupo heterogêneo de pessoas, não necessariamente informado sobre todos os aspectos da notícia" (p. 23);

- a importância do gancho jornalístico, ou seja, a pauta da reportagem que considerar a relevância de um fato da atualidade de impacto social;

- a escolha da informação mais interessante ao leitor e ao debate público para a composição do lide (p. 28);

- o estudo do espaço disponível para otimização de notícias ou reportagens de acordo com a sua relevância e circulação em outros meios (p.30);

- o equilíbrio entre texto e imagem a fim da "valorização da informação visual dentro das concepções" (p.33);

- atenção à sequência de títulos e reportagens em cada caderno, a fím de proporcionar uma hierarquização condizente com o interesse dos leitores do jornal (p. 34);

A partir do Manual, pudemos compreender alguns modos de produção dos enunciados que circulam as publicações impressas e digitais, de acordo com as orientações direcionadas aos jornalistas-autores, no tocante aos aspectos estilísticos do gênero reportagem, bem como o estilo previsto no projeto editorial da FSP. No entanto, entendendo a concretização do enunciado enquanto fenômeno único e irrepetível, novamente de acordo com a teoria bakhtiniana, obviamente teremos que considerar as particularidades de cada reportagem no momento de sua produção e circulação. Somente após a análise apurada de cada enunciado, juntamente com a caracterização da esfera de produção descrita acima, poderemos depreender as relações dialógicas que permeiam o discurso de DC tanto da FSP quanto da FO. 


\subsubsection{Conteúdo temático}

Para a apreensão da definição de conteúdo temático, recorremos a três obras do Círculo de Bakhtin - Marxismo e Filosofia da Linguagem (2004 [1929]); The formal method in literary scholarship 1991 [1928]) e Os gêneros do discurso (2003 [1952-53]) em que o conceito é desenvolvido a partir dos seguintes eixos: primeiramente, na oposição entre infra e superestrutura; em seguida, como um aspecto enaltecedor da crítica ao método formalista; e, finalmente, como um dos elementos constitutivos do gênero discursivo, ao lado de estilo e forma composicional.

Em Marxismo e Filosofia da Linguagem (2004 [1929]), os autores iniciam uma reflexão sobre como o signo passa ter caráter ideológico na medida em que transita da infra para a superestrutura. No plano superestrutural, o fenômeno da significação, que é da ordem da língua e está contido no signo linguístico, é envolto pelo conteúdo temático do enunciado concreto já ideologizado. O tema ideológico é imbuído dos contextos sóciohistóricos que o embalam, resultando em uma realidade extraverbal, que é organizada pelos sistemas verbais e verbo-visuais.

Sobre a relação entre significação e tema, os autores ressaltam que:

O tema é um sistema de signos dinâmico e complexo que procura adaptar-se adequadamente às condições de um dado momento da evolução. O tema é uma reação da consciência em devir ao ser em devir. A significação é um aparato técnico para a realização do tema. (...) Não há tema sem significação e vice-versa. (p.129)

A partir da ideia de que a significação é um estágio anterior do sentido e o tema é a sua plena concretização, Bakhtin / Medvedev (1928) desenvolvem a sua crítica ao método formal. Segundo os autores, apesar de não serem dissociáveis, essas duas facetas do sentido devem ser diferenciadas, o que não ocorre na análise dos formalistas russos daquela época. O tema do enunciado não corresponde somente à materialidade da língua, mas que também estabelece-se em uma dada situação social e histórica: 
É o todo do enunciado e suas formas, que não podem ser reduzidas a nenhuma forma linguística, que controlam o tema. (...) Consequentemente, é inseparável da situação total do enunciado enquanto é inseparável dos elementos linguísticos. (Bakhtin / Medevdev: 1928/1991, p.132) ${ }^{53}$

O tema é descrito por ser o fenômeno responsável pela apreensão comunicativa de aspectos da realidade, e se torna uma unidade que transcende o nível linguístico em sua materialidade. Em The formal method in literary scholarship, Bakhtin / Medevdev $(1928 / 1991)$ afirmam que o tema do enunciado não corresponde somente à materialidade da língua, mas que também estabelece-se em uma dada situação social e histórica.

Na obra mais recente, Os gêneros do discurso (1952-53), Bakhtin situa o conteúdo temático como um dos elementos constitutivos do gênero, uma vez que é por meio do tema que o gênero reflete e refrata dada realidade em todas as esferas da atividade humana. Assim como observamos em relação à forma composicional anteriormente, o tema é parte fundamental dos enunciados concretos, determinando a sua conclusibilidade.

O conteúdo temático pode, então, ser considerado o reflexo imediato e a refração da realidade, da situação extraverbal. De acordo com a análise metalinguística proposta por Bakhtin em PPD, levamos em consideração duas dimensões, a linguística e a extralinguística. Nessa mesma obra, Bakhtin refere-se ao tema de diversas formas, como bem aponta Cereja (2005, p.203), a partir dos seguintes termos: significação ideológica, significação semântica, significação objetiva ou significação concreta. Logo, todo objeto de análise deve ser tomado tanto sob o ponto de vista do enunciado como uma unidade discursiva, dotado de sentido e autoria, em suas formas relativamente estáveis, quanto da materialidade linguística e de suas próprias unidades distintivas.

Nosso modelo de análise está baseado na noção de hipertextualidade como um tipo de relação dialógica e nas unidades constitutivas do gênero discursivo que acabamos de apresentar. No entanto, antes de entrelaçar os fios teórico-metodológicos que antecedem a análise, propomos uma reflexão sobre a divulgação científica e as esferas de circulação dos enunciados que compõem o corpus.

\footnotetext{
53 "It is the whole utterance and its forms, which cannot be reduced to any linguistic forms, which control the theme. (...) Consequently, it is inseparable from the total situation of the utterance to the same extent that it is inseparable from the linguistic elements", (Bakhtin / Medevdev: 1928/1991, p.132).
} 


\subsection{Um enunciado e diversas esferas: a DC na FSP como parte da formação da cultura científica na primeira década dos anos 2000}

A constituição do corpus pode ser considerada uma particularidade da atual pesquisa. Temos enunciados com a mesma forma lógica, tal como vimos anteriormente nesse mesmo capítulo, mas que são concretizados em diferentes meios, cada qual com suas características, emergentes na fronteira de esferas cuja conjunção é única.

No meio impresso, há enunciados que possuem autonomia de sentido, mas que podem ser conglomerados para formar uma reportagem maior e mais complexa. Já no meio digital, cada enunciado equivale a uma reportagem. Além da diferença no que tange à conclusibilidade dos enunciados impressos e digitais, faz-se imprescindível reconhecer que os temas apreendidos também são distintos - lembrando que o conteúdo temático, ao lado da forma composicional do gênero, contribui para o acabamento do enunciado.

Não somente os temas e a composicionalidade configuram-se como divergentes entre o impresso e o digital, mas as próprias esferas das quais emergem tais enunciados apresentam particularidades. As reportagens de DC no impresso são formuladas na fronteira entre as esferas jornalística e científica, atravessadas pelo discurso político, sobretudo nos anos inicias do estudo. As reportagens de DC no digital, possuem as mesmas características, com um certo enfraquecimento das questões políticas por conta da autonomia semânticoaxiológica dos enunciados, mas com a transposição da esfera digital, como propomos no capítulo 2. Uma vez já discutida a transposição da esfera digital sobre as demais na FO, abrimos espaço para a discussão da própria DC, variante que se repete nos dois jornais.

O espaço para DC foi primeiramente estabelecido na FSP que possui uma editoria própria para assuntos da ciência. Na FO, há uma editoria única de gestão do jornal e grande parte das reportagens do portal de ciência é importada do jornal impresso. Com o passar dos anos, vimos que a FO começa a perder o caráter de 'versão do jornal impresso' para constituir-se como um veículo mais autônomo e a produção de notícias e reportagens aumente nesse meio. Enquanto isso, a 'Folha Ciência', editoria que ocupa de uma a duas páginas do jornal impresso, passou por um período de constantes mudanças para uma estabilização na FSP.

Conforme descrevemos anteriormente, somente em 2006 as reportagens de DC ocuparam, definitivamente, a última ou as duas últimas páginas do primeiro caderno da FSP. As reportagens de DC, mesmo no período de transição entre páginas, nunca deixaram de participar do primeiro caderno, muitas vezes, dialogando com os editoriais ou mesmo outras 
reportagens e notícias sobre política mundial ou nacional. O espaço da ciência na FSP, principalmente no início dos anos 2000, não deixa de ser um canal para discussão de aspectos políticos, orientado pelo discurso científico.

A estabilização da seção 'Folha Ciência' é fruto da consolidação do discurso de DC no jornal, em conjuntura com a própria consolidação da Cultura Científica no país e com a expansão da própria tecnologia digital. Sob o ponto de vista da tecnologia Moura (2006, p.140) afirma que:

\begin{abstract}
Nesse tempo-lugar de transição, pensar os meios de comunicação para além de seus dispositivos tecnológicos - ou seja, o rádio, a televisão, a rede mundial de computadores, a imprensa -, detendo o olhar nas novas relações pessoais e sociais que a mídia enseja, permite certamente estender com mais acuidade o pensamento para o espaço público e a sociedade. Não se trata de teorizar a mídia para explicálos, mas sim de saber que é impossível pensar contemporaneamente essas dimensões sem uma compreensão mais profunda da mídia e da comunicação. (Moura, 2006, p.140)
\end{abstract}

No ano de 2006, não somente houve uma mudança estilístico-composicional profunda no modo de apresentação dos enunciados impressos, mas a tematicidade das reportagens também deu indícios do apagamento das marcas do discurso político como confirmamos na análise. Ao mesmo tempo, a internet estava em plena expansão e os mecanismos remissivos no meio impresso foram mais recorrentes.

A autora fornece dados estatísticos que corroboram para nossas observações sobre o ano de 2006:

Já a novíssima mídia eletrônica fundada nos computadores e na internet alcançou 13,4 milhões de usuários residenciais ativos, em julho de 2006, segundo dados do Instituto Brasileiro de Opinião Pública e Estatística (Ibope). Parte fundamental da mídia, os jornais diários chegam usualmente no país a 12 milhões de pessoas - das quais 3,9 milhões leem algum jornal todos os dias. (Moura, 2006, p. 147)

Entretanto, a consolidação do espaço das reportagens de DC na FSP também é reflexo da evolução da cultura científica no país: 
É importante ressaltar que a participação brasileira na produção científica mundial já em 2002 era maior que sua participação no comércio internacional no comércio internacional, da ordem de 1,2\%, Assim, já somos melhores produtores de conhecimento do que de comodities. (Moura, 2006, p.149)

O conceito de cultura científica foi introduzido pelo linguista Carlos Vogt em seu artigo A espiral da cultura científica, publicado na edição no. 45 do site de DC intitulado Com Ciência. Trata-se de um conceito mais amplo que incorpora os processos de criação e circulação do conhecimento gerada na esfera científica, em que a DC configura-se como prática essencial. É por meio da difusão e dos processos de ensino-aprendizagem promovidos pelas práticas de DC que os indivíduos não pares são ligados a toda a esfera de produção da ciência. Vogt (2003) propõe um movimento espiralado partindo das entidades e sujeitos criadores no âmbito científico seguindo para o plano de formação do corpo científico. Em seguida, o movimento segue de acordo com os processos educacionais que visam à difusão do conhecimento gerado nas etapas anteriores e, finalmente, a DC fecha o ciclo levando os fatos da ciência a conhecimento do grande público.

A DC, portanto, participa de uma complexa esfera de produção, circulação e recepção que vem sendo cada vez mais consolidada em território brasileiro, como mostram os Indicadores de Ciência, Tecnologia e Inovação (C,T\&I) elaborados pela agência de fomento à pesquisa FAPESP (Fundação de Amparo à Pesquisa do Estado de São Paulo), bem como os Indicadores de Ciência e Tecnologia (C\&T) do governo federal, promovidos pelo Ministério da Ciência, Tecnologia e Inovação (MCTI). Para o contexto de nossa tese, consultamos os três últimos indicadores da agência FAPESP, seguindo o recorte regional sugerido pelos jornais FSP e FO.

Em 2001, políticas públicas para a maior expansão e divulgação das práticas científicas estavam em desenvolvimento. Considerando a ainda recente inserção da tecnologia digital para uso comercial, há um capítulo que trata da divulgação em meio impresso em vários momentos. O relatório faz uma significativa observação no tocante ao reconhecimento da ciência pela sociedade e ao modo como os jornais apreendem e veiculam os conteúdos da esfera científica: 
O fenômeno de uma sociedade reconhecer que a atividade científica tem direito à existência, e separar recursos especialmente para mantê-la, corresponde à legitimação social da ciência, e é o que permite sua institucionalização, ou seja, sua organização em instituições específicas, regidas por seus próprios ritos e mecanismos de validação. (Brisolla \& Carvalho, 2001, p.17)

Os jornais realmente se interessam por assuntos de ciência e tecnologia, ao contrário do que se constatou em outros levantamentos, feitos nos anos 80. A ciência nacional ocupa mais espaço na mídia do que a produzida no país. (...) A pesquisa indica ainda alguma preferencias da mídia. Os temas em destaque são geralmente os de natureza mais prática, com algum poder de intervenção na realidade local, regional e até nacional, o que se vê pela predominância das engenharias, das ciências agrárias, das questões ambientais e das ciências da saúde (Brisolla \& Carvalho, 2001, p.18)

Nos indicadores de 2004, observamos a inserção de um capítulo intitulado “Tecnologias de Informação e Comunicação (TICs) e Redes Digitais". A repercussão da DC nas redes digitais é considerada ainda imatura, mas a sua rápida ascensão fez com que se tornasse um dos indicadores eleitos pela FAPESP nesse ano. Tal acontecimento reforça as observações que temos feito sobre a consolidação da DC nas páginas do impresso aliada ao fortalecimento da autonomia do meio digital.

Ainda em 2004, a FAPESP levantou a valoração das informações atribuídas ao jornalista e ao cientista para o público presumido, enquanto "agentes mais relevantes da comunicação pública da ciência em termos de idoneidade profissional e credibilidade comunicativa" (2004, p.22). No que tanga à clareza da linguagem da DC:

As respostas tendem a considerar que somente em algumas ocasiões a comunicação dos cientistas com a sociedade é de difícil compreensão. Os entrevistados pressupõem, com isso, que a eventual incapacidade de comunicação dos cientistas não é uma condição estrutural de suas competências profissionais, mas está associada, fundamentalmente, a outros fatores. (p.22)

Ressaltamos que a autoria dos enunciados que circulam tanto na FSP quanto na FO pertence a jornalistas que, mesmo com alguma especialização em um domínio científico específico, não possuem formação tão aprofundada quanto à de um cientista. Mais que isso, jornalistas são sujeitos que atuam em outra esfera da atividade humana e, portanto, sua 
posição ideológica ${ }^{54}$ difere da de um cientista. Em publicações especializadas em DC em que os autores são cientistas o conteúdo temático sofre diferenças por conta do nível de aprofundamento alcançado. O discurso gerado pelo jornalista, não por acaso, faz maior uso de recursos verbo-visuais, tal como os infográficos, para explicar conceitos complexos.

A questão da autoria revela-se em nosso corpus na medida em que observamos que o discurso de divulgação científica é atravessado pelo discurso político de forma mais contundente. No jornal que circula em uma esfera voltada para não pares, cujo leitor presumido é constituído por um corpo heterogêneo de sujeitos, e com a presença de grande interesse mercadológico acerca da tiragem de exemplares, o jornalista assume, ao mesmo tempo, a missão de divulgar a ciência de forma didática junto ao interesse dos seus leitores, e atender à demanda comercial imposta pela empresa de comunicação para a qual trabalha. Ao passo em que o cientista utiliza o meio de comunicação para divulgar seu trabalho no domínio científico, o jornalista utiliza os conteúdos do meio científico para promover outro produto final, o jornal. Portanto, as diferentes posições sociais, históricas e ideológicas que constituem esses sujeitos, interferem no modo de produção e apreensão dos seus enunciados, seja do ponto de vista estilístico, temático ou composicional.

\subsection{Entrelaçando os fios teórico-metodológicos}

Participando de um evento acadêmico ${ }^{55}$ sobre estudos discursivos em diferentes pluralidades teóricas deparamo-nos com um questionamento sobre a produtividade de uma análise bakhtiniana do discurso. Encontramos na síntese para o fechamento do terceiro capítulo um espaço para responder à tal questão. Entretanto, respondemos à tal enunciado a partir da posição de quem fez um estudo sobre a teoria bakhtiniana, mas que também procurou compreender como algumas teorias desenvolvem seus conceitos e os aplicam em suas análise, como mostramos no primeiro capítulo.

Ao contrário da $\mathrm{AD}$ francesa, por exemplo, - da qual podemos citar os modelos de Authier-Revuz e Pêcheux na França e o de Eni Orlandi no Brasil -, não encontramos um dispositivo de análise específico elaborado por Bakhtin e seu Círculo, ou mesmo instruções sobre a apreensão e tratamento do corpus, sobretudo um corpus formado por enunciados de

\footnotetext{
${ }^{54}$ Nesse sentido, referimo-nos a ideologia como a própria posição histórico-social da qual discursa o sujeito, tal como descrita por Bakhtin / Volóchinov em Marxismo e filosofia da linguagem (2004 [1929]).

${ }^{55}$ O IV EPED - Encontro de Pós-Graduandos em Estudos do Discurso - realizado na Faculdade de Filosofia, Letras e Ciência Humanas da Universidade de São Paulo, ocorrido em marco de 2012.
} 
natureza não literária. Contudo, para além da teoria, Bakhtin elaborou uma disciplina que trata de enunciados concretizados na vida, capaz de compreender as relações axiológicosemânticas a partir de elementos verbais e extraverbais - sócio-históricos - , a Metalinguística. A disciplina permite ao analista o exame profundo das relações dialógicas entre enunciados e a apreensão do entrecruzamento de discursos e esferas. A proposta de nossa tese é um exemplo de que o modelo bakhtiniano pode ser utilizado para compreender os modos de produção, recepção e circulação de enunciados que não pertencem à esfera literária e muito menos são contemporâneos aos autores do Círculo, os enunciados digitais.

As noções elaboradas pelo Círculo e as análises deixadas por Bakhtin, sobretudo em relação às obras de Dostoievski, fornecem elementos adequados para a constituição de novos modelos de análise. Em nossa tese, procuramos olhar para o corpus a partir dos conceitos de gênero discursivo e relações dialógicas, a fim de formular uma proposta analítica que desse conta do fenômeno da hipertextualidade em reportagens de DC impressas e digitais.

A teoria bakhtiniana auxilia-nos a criar um caminho para a observação do corpus e, na medida em que esse responde, permite-nos voltar para o modelo teórico-metodológico para uma maior reflexão de nossa própria prática analítica. Podemos citar como exemplo, o fato de a análise ter iniciado sob o prisma da forma composicional dos enunciados, tendo de ser estendida mais tarde, uma vez que tal noção no âmbito da Teoria Dialógica não pode ser dissociada das noções de estilo e conteúdo temático. Logo, o diálogo entre teoria e corpus dita os movimentos do analista.

Seria a aparente falta de dispositivo, o verdadeiro dispositivo analítico que Bakhtin empenhou em suas análises e que faz inspirar tantas outras? Em nossa tese, partimos do desenvolvimento da noção de hipertextualidade como uma modalidade dialógica entre enunciados e procuramos verificar na análise de que forma tal relação dialógica é dada em enunciados concretos. Portanto, tivemos que olhar para tais enunciados na sua relação com o gênero - descrevendo e entendendo as suas partes constitutivas ao longo dos anos escolhidos - e as esferas de atividade humana - considerando os meios de circulação impresso e digital. Além disso, um fator crucial foi a contextualização sócio-histórica de cada reportagem, uma vez que a realidade apreendida pelos gêneros discursivos manifesta-se por meio dos processos de axiologização e ideologização dos enunciados.

De forma mais específica, procuramos verificar as relações dialógicas hipertextuais a partir de nós remissivos que estivessem presentes em aspectos de ordem linguística; nos elementos da forma composicional do gênero reportagem de DC, como a hiperestrutura e o hipertexto; na dimensão verbo-visual dos enunciados; nas marcas estilísticas de acordo com 
o autor e a caracterização do leitor presumido; e nos conteúdos temáticos gerados em cada enunciado. Mais do que uma proposta teórico-metodológica, mas sim teórico-analítica, esperamos ter contribuído para o estabelecimento de uma maneira para se olhar para o corpus, sem a pretensão de constituirmos um dispositivo, mas que poderá servir a futuras análises em algum sentido.

Acrescentamos que a aplicação de um mesmo dispositivo de análise em perspectiva bakhtiniana não seria possível por conta de um aspecto fundamental da teoria: o enunciado é único e irrepetível. O seu processo de enunciação dá-se em um momento e espaço sóciohistórico cuja configuração jamais será dada uma segunda vez. Portanto, cada análise dialógica também se torna única, mas não deve, sem dúvida, esgotar-se em si mesma. Como dissemos acima, uma análise dialógica, constituindo-se a partir da responsividade e dialogismo em relação às demais, serve, ao mesmo tempo, como resposta às anteriores e como base para as futuras.

Para a análise com base nas diretrizes estabelecidas nos capítulos anteriores, sobretudo o terceiro, selecionamos um dia de publicação de cada ano - a saber, 2000, 2003, 2005, 2006, 2007 e 2008 - confrontando as reportagens da página do jornal impresso com aquelas publicadas no jornal digital, no mesmo dia. Considerando a reformulação editorial observada quanto aos aspectos composicionais e estilísticos do jornal impresso em 2006, dividimos a análise em dois capítulos distintos, conforme apresentamos em seguida. 


\title{
CAPÍtTULO 4.
}

\section{RELAÇÕES DIALÓGICAS HIPERTEXTUAIS EM REPORTAGENS DE DC DE 2000 A 2005: O ENTRECRUZAMENTO DOS DISCURSOS CIENTÍFICO E POLÍTICO}

\author{
Um galo sozinho não tece uma manhã: \\ ele precisará sempre de outros galos. \\ De um que apanhe esse grito que ele \\ e o lance a outro; de um outro galo \\ que apanhe o grito que um galo antes \\ e o lance a outro; e de outros galos \\ que com muitos outros galos se cruzem \\ os fios de sol de seus gritos de galo, \\ para que a manhã, desde uma teia tênue, \\ se vá tecendo, entre todos os galos. \\ E se encorpando em tela, entre todos, \\ se erguendo tenda, onde entrem todos, \\ se entretendendo para todos, no toldo \\ (a manhã) que plana livre de armação. \\ A manhã, toldo de um tecido tão aéreo \\ que, tecido, se eleva por si: luz balão.
}

(Tecendo a manhã, João Cabral de Melo Neto, 1979)

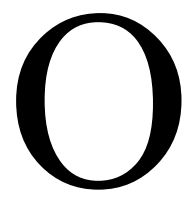

modelo de análise que propomos anteriormente constitui-se basicamente a partir das seguintes diretrizes: contextualização sócio-histórica ampla e imediata das reportagens; a descrição dos elementos constitutivos do gênero discursivo; e a observação das características do meio impresso e digital. Tais orientações foram estabelecidas para que pudéssemos encontrar a hipertextualidade como um tipo de relação dialógica entre os enunciados do corpus, acreditando que a sua articulação é motivada pelos elementos do gênero discursivo, do meio e suas respectivas esferas, bem como pela conjuntura sócio-histórica de sua época.

Acrescentamos que o olhar para os enunciados também é regido pela definição de que a internet conglomera variadas esferas da atividade humana sobre as quais sobrepõe-se a esfera digital; pela constatação de que a conclusibilidade dos enunciados difere de acordo com o meio; e pela constatação de que, apesar de possuírem a mesma forma lógica, os enunciados da FSP e da FO são únicos em sua concretização. Iniciamos o presente capítulo 
com uma contextualização sócio-histórica mais abrangente no que tange aos próximos dois capítulos, refletindo sobre os aspectos mais contundentes da primeira década dos anos 2000 .

Como sabemos, os anos 2000 não inauguraram somente uma nova década, mas também um novo século e milênio. Apesar de o ano 2000, em particular, ainda pertencer ao século XX, foi nesse momento que a população mundial aguardava pelo tão temido "bug do milênio" que poderia vir a acometer todo o sistema computacional na troca dos dígitos 1999 a 2000. A tensa passagem para os novos dígitos no calendário só não foi mais intensa do que a mobilização mundial gerada pela queda das Torres Gêmeas em setembro de 2001, fruto de um ataque terrorista da organização Al Qaed. Se o início dos anos 2000 foi pleno de expectativas e apreensões, o fim de sua primeira década é marcado por grandes crises econômicas, revoluções democráticas em países árabes e o acirramento em torno das discussões climáticas do planeta.

De uma ponta a outra, atentamos para um fator que permeou não somente os acontecimentos históricos, mas que interferiu na própria História e condição social dos sujeitos em todo o mundo. A disseminação da internet, que já havia sido aberta ao uso comercial a partir de 1995, possibilitou maior acesso às informações em uma nova era em que, parafraseando o jargão americano, "Information is Money". Os terroristas vislumbraram que os ataques a Nova Iorque e ao Pentágono seriam transmitidos ao vivo pela televisão, mas além disso, talvez não contassem com o fato de que a possibilidade de armazenamento de dados e rápido acesso à internet faria com que as diversas imagens gravadas fossem eternizadas e disponibilizadas ao alcance de todos. Não somente o $9 / 11$, mas os seus desdobramentos foram registrados e acompanhados - de forma distorcida ou não, uma vez que as fontes e o apagamento da autoria na rede são questões que merecem discussão ainda hoje -, tal como no caso em que fotografias de soldados americanos torturando presos de guerra no Afeganistão foram veiculadas via e-mails e redes sociais.

Além da cobertura televisiva e registros fotográficos no domínio da imprensa, cidadãos comuns puderam fazer seus próprios registros, como no caso da garota egípcia que postou a filmagem da barbárie cometida pela ditadura de seu país na rede social mais difundida até hoje, o Facebook. Menos de dois anos mais tarde, o uso da internet como forma de contestação de governos ditatoriais contribui para a disseminação da chamada Primavera Árabe, movimento revolucionário iniciado na Tunísia que contaminou todos os países árabes da região do Magrebe, no noroeste da África.

No cenário mundial, os estrondosos investimentos na guerra do Afeganistão contribuíram para a crise interna americana que também vem desestabilizando governos 
europeus. Em 2010, é lançado o WikiLeaks, site criado pelo australiano Julian Assange, cujo intuito era publicar na rede mundial documentos oficiais de governos e grandes corporações sobre assuntos que caracterizariam corrupção ou qualquer tipo de favorecimento indevido. Além de preso, Assange foi indicado ao prêmio Nobel da Paz por divulgar vídeos de ataques norte-americanos a civis no Iraque e telegramas oficiais do governo sobre assuntos de guerra. Definitivamente, a internet como um conjunto de esferas da atividade humana, também passou a acolher práticas ativistas que têm sido bem sucedidas por conta de uma característica constitutiva da rede: a descentralização da informação. Assim como a própria vida e as esferas pelas quais os sujeitos circulam por meio de seus discursos, a internet é capaz de reproduzir as mesmas esferas, cada vez mais, pois possibilita a inserção do sujeito enquanto autor e não somente como destinatário.

Devido à alta capacidade de promover interação entre sujeitos usuários da rede, a conectividade digital tem sido uma ferramenta social para a comunicação e fortalecimento do processo de mundialização. Os enunciados gerados na era de disseminação digital foram e são passíveis de uma reflexão coletiva maior o que, certamente, vem modificando os modos de produção, sobretudo na esfera jornalística. Recentemente, em 2011, a própria FO lançou um espaço como o WikiLeaks, para que os leitores pudessem encaminhar documentos, imagens ou qualquer tipo de material que contribuísse para a elaboração de uma reportagem consistente acerca de qualquer assunto de interesse da população. O verso de João Cabral de Melo Neto (1979) parece muito oportuno para o modo com que o alto grau de informatividade contribui para a formação dos enunciados atualmente: "um galo sozinho não tece uma manhã".

\subsection{Reportagens do ano 2000: a política impregnada nas tramas de um discurso sobre o meio ambiente}

Do panorama contextual mais amplo referente à primeira década dos anos 2000, passamos para um recorte sócio-histórico mais restrito ao primeiro ano de análise selecionado. Do final do ano 2000, destacamos a efervescente corrida eleitoral nos Estados Unidos que culminava na contagem duvidosa de votos no estado da Flórida, garantindo a reeleição do então presidente George W. Bush. A reportagem principal na capa da FSP trazia o seguinte título: "Eleição nos EUA espera recontagem". A gafe da imprensa americana no acompanhamento da contagem dos votos, assim como a falha no próprio sistema eleitoral 
foram fortemente repercutidas no editorial da edição. Ao passo que os comentários e opiniões dos colunistas focam o contexto norte-americano, a FSP publica a seguinte charge:

Figura (8) Reprodução da charge publicada na seção editorial do dia 09/11/2000

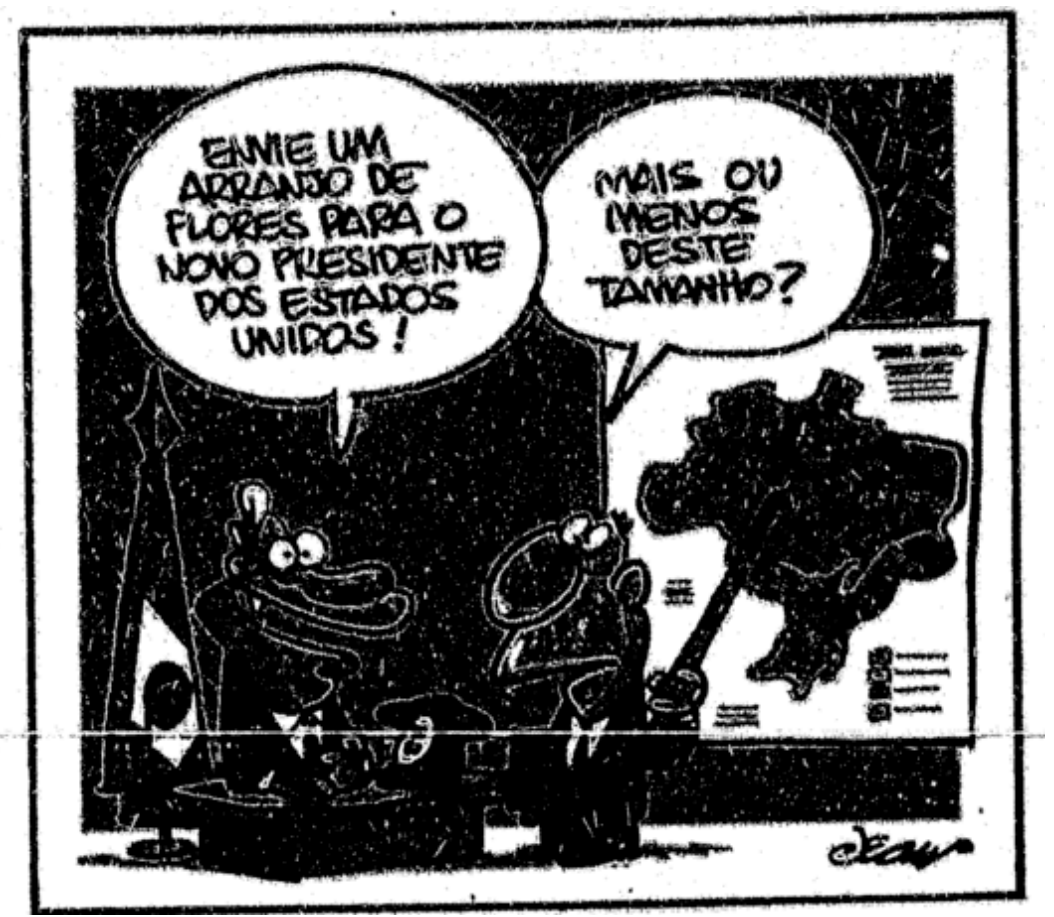

$\mathrm{Na}$ charge, o presidente Fernando Henrique Cardoso (doravante FHC) está representado em seu gabinete comentando a possível vitória de George W. Bush. O mote da charge está no fato de que o buquê de flores a ser oferecido ao presidente americano equivale a uma porção da floresta amazônica, como o chargista coloca em destaque na indicação feita ao mapa do Brasil. Mais adiante, ainda no primeiro caderno do jornal do dia 09/11/2000, outro enunciado evidencia a relação entre os presidentes. 


\section{Líderes estrangeiros felicitam Bush antes da hora}

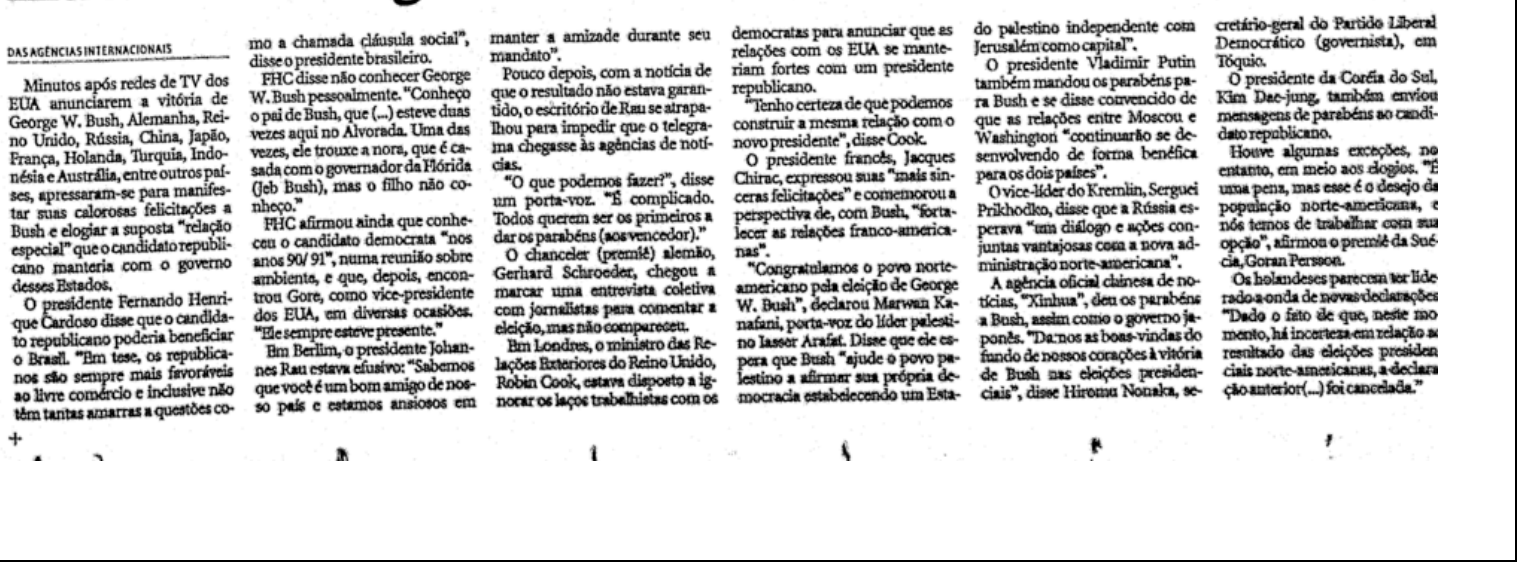

Em meio à balbúrdia da possível reeleição, vários presidentes já haviam felicitado Bush, inclusive FHC, cuja reação foi retratada pelo jornalista da seguinte forma:

O presidente Fernando Henrique Cardoso disse que o candidato republicano poderia beneficiar o Brasil. "Em tese, os republicanos são sempre mais favoráveis ao livre comércio e inclusive não têm tantas amarras a questões como a chamada cláusula social”, disse o presidente brasileiro. (Folha de S. Paulo, editoria Folha Mundo, 09/11/2000)

Os dois enunciados reproduzidos estabelecem uma relação dialógica divergente. $\mathrm{O}$ discurso de FHC revela a forma com a qual o Brasil pode ser beneficiado pela reeleição de Bush, o que, no entanto, é retomado pelo chargista como uma inversão de valores. $\mathrm{Na}$ charge, notamos claramente a posição contrária de que o beneficiado será os EUA por meio do uso de recursos naturais da Amazônia. Não por acaso, o jornalista afirma no texto que ambos os presidentes haviam se conhecido em uma convenção mundial sobre o clima, assunto principal da reportagem da editoria de ciência da mesma data, também publicada no Primeiro Caderno. Por sua vez, os enunciados acima antecipam a polêmica ${ }^{56}$ que será

\footnotetext{
${ }^{56}$ Entendemos a polêmica como um conceito formulado por Bakhtin na obra Problemas da poética de Dostoiévski (2010 [1963]). Trata-se de uma característica do terceiro tipo de discurso identificado por Bakhtin no conjunto de obras de Dostoiévski, o discurso orientado para o discurso de outrem. A polêmica pode ser aberta ou velada. A polêmica aberta constitui-se pelo uso do discurso de outrem como objeto de refutação. Enquanto isso, a polêmica velada insere-se em um discurso orientado para seu objeto, em que seu próprio
} 
instaurada entre os enunciados que compõem não somente a reportagem, mas toda a página da editoria da 'Folha Ciência' em que FHC é personagem central, ao lado do seu próprio discurso.

Para além das páginas do jornal impresso, no mês de novembro de 2000, houve a Convenção Mundial sobre o Clima em Haia, na Holanda. O evento visava à criação de mecanismos para que os países diminuíssem as emissões dos gases que causam o efeito estufa. Durante todo o mês de novembro foram publicadas reportagens que discorriam direta ou indiretamente a respeito da Convenção, cujo objetivo maior era a redução da emissão de gases pelos países desenvolvidos, dentre os quais os EUA eram o maior responsável.

$\mathrm{Na} F O$, dos 142 registros de enunciados encontrados no mês de novembro, 33 eram voltados à Convenção de Haia ou a assuntos relacionados ao acontecimento, como o efeitoestufa, o aquecimento global e o desmatamento de florestas. Já na FSP, registramos 24 enunciados, do total de 82 que haviam sido publicados ao longo do mês inteiro. Logo, podemos inferir que a questão obteve uma centralidade maior na FSP no mês de novembro, do que para a FO.

Outro aspecto que deve ser levado em consideração é o fato de que a forma lógica dos enunciados dispostos na rede foi importada integralmente da FSP, não apresentando quaisquer modificações no que tange a sua composição verbal, ou seja, em relação aos seus parágrafos e elementos peritextuais. Sendo assim, constatamos que a autoria dos enunciados é a mesma em ambos os meios e os juízos de valores implícitos também.

$\mathrm{O}$ autor da primeira reportagem da página que selecionamos para análise é Marcelo Leite, jornalista e cientista social, especializado em jornalismo científico que, na época, já havia atuado como ombudsman da segunda reportagem é o jornalista especializado em ciência e meio ambiente Cláudio Ângelo, que passou a ser o editor de ciência da FSP a partir de 2004, sendo no momento da publicação em questão, apenas colaborador da seção. Retomando a discussão sobre a autoria iniciada no capítulo anterior, lembramos que, ao contrário do autor-cientista, o jornalista científico utiliza o discurso científico como palco para a elaboração de temas de ordem social e, sobretudo, política. Certamente, o cientista também mobiliza conteúdos temáticos políticos, mas esses geralmente são pertinentes à própria esfera científica. No caso dos enunciados da FSP e, principalmente por fazer parte do caderno voltado para a discussão dos cenários políticos nacional e internacional, o jornalista

sentido objetivo é resguardado, ao mesmo tempo em que se choca com o discurso do outro orientado para o mesmo objeto. Veloso (2011), que elaborou sua tese em torno das entrevistas do programa televisivo Roda Viva, define a polêmica como um tipo de refração discursiva de diferentes tonalidades no enunciado. 
parece não aprofundar-se nos conceitos da ciência, mas sim, utiliza o discurso sobre a ciência como um motivo para estender a discussão política que pauta a edição do dia.

Devemos considerar ainda que o leitor presumido da editoria de ciência da FSP seja um leitor potencial do 'Primeiro Caderno', espaço de discussão de questões políticas. Pudemos obter informações precisas sobre o leitor presumido da época por meio de uma pesquisa realizada no ano 2000 pelo DataFolha e comentada pelo jornalista Vinicius Mota, então editor de Opinião do jornal. Em artigo publicado na FO, no ano em que a FSP completava 80 anos, Mota (2000) revelou que o público presumido da publicação naquela época possuía um padrão de renda elevado, pertencendo a classes mais favorecidas e de alta escolaridade em sua maioria. Ao entrevistar Otavio Frias Filho, diretor de redação do jornal, Mota apurou que o perfil do público alvo da FSP apontava para o fato de que o jornal havia atingido o objetivo de se inserir como um veículo mobilizador de opinião pública brasileira, mas perdia espaço entre os jovens.

Paralelamente, o público presumido das publicações da FO pertencia a uma gama de indivíduos que vivenciavam a adequação à tecnologia digital. A difusão do meio digital ainda não era vasta e a FO deveria ser uma opção menos popular, o que nos leva a crer que o leitor fazia parte de um grupo de sujeitos menos heterogêneo. Somente os que dominavam a tecnologia e tinham acesso ao computador é que podiam acessar a publicação da FO, numa época em que a exclusão digital era maior. Diferentemente do que ocorre na FSP, a editoria de 'Ciência' da FO é independente das seções 'Mundo' e do 'Editorial' o que, certamente, confere diferenças ao conteúdo temático de seus enunciados, como averiguamos nos itens que seguem.

\subsubsection{Uma abordagem metalinguística sobre o enunciado-fonte}

O percurso que adotamos para a análise partiu do que consideramos o enunciadofonte da página do jornal impresso publicado em 09/11/2000, "FHC omite as florestas ao abordar mudanças no clima”. Exatamente na página 11 do 'Primeiro Caderno', temos a seguinte configuração estrutural representada na tabela (6), seguida da reprodução da página original: 


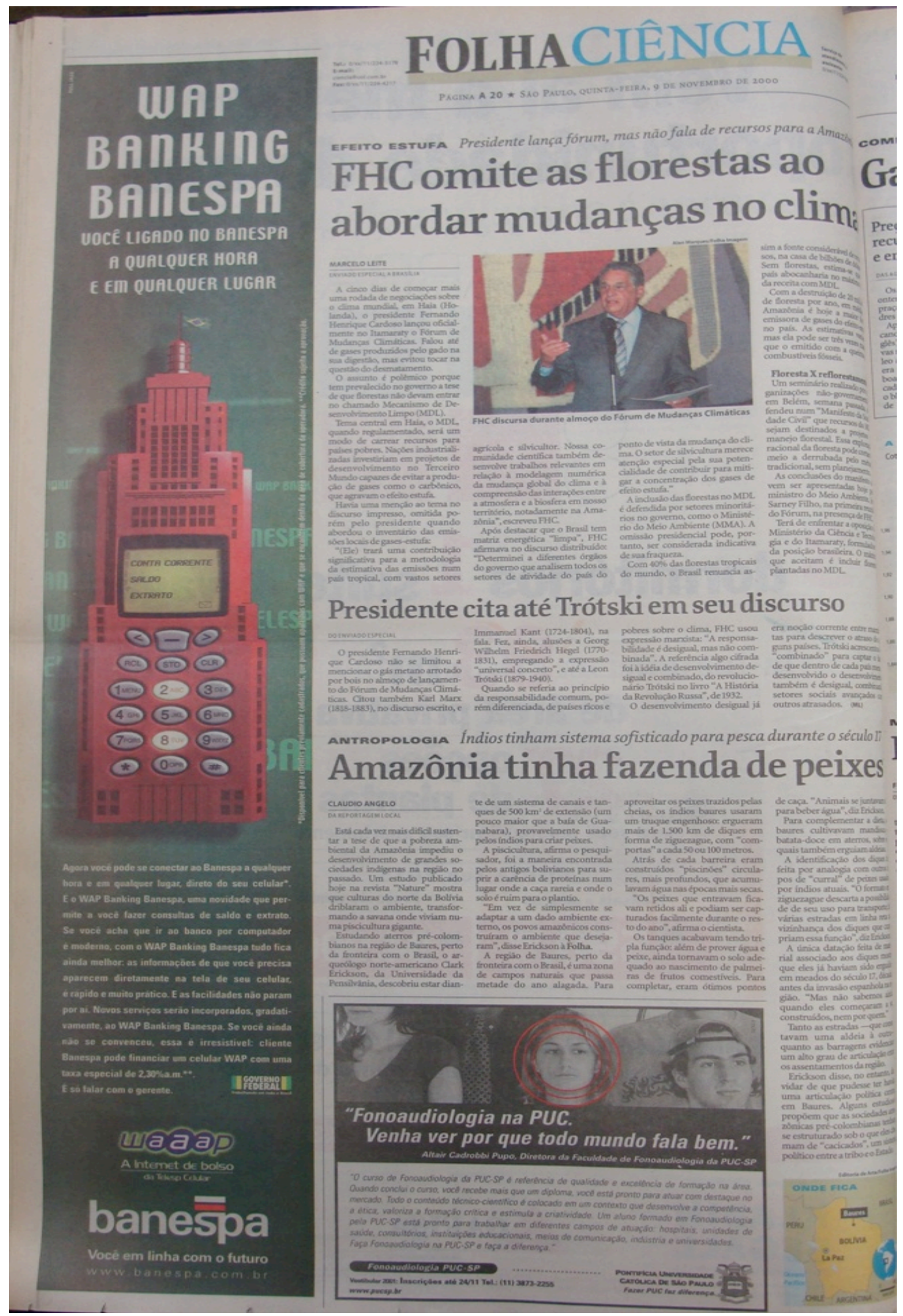


Tabela (6) Hiperestrutura da Folha de S. Paulo, 09 de novembro de 2000.

\begin{tabular}{|c|c|c|}
\hline & & REPORTAGEM 1 \\
\hline \multirow{3}{*}{$\begin{array}{c}\text { ENUNCIADO } \\
1\end{array}$} & $\begin{array}{l}\text { Chapéu e } \\
\text { título auxiliar }\end{array}$ & $\begin{array}{l}\text { Efeito Estufa: Presidente lança fórum, mas não fala de recursos para a } \\
\text { Amazônia }\end{array}$ \\
\hline & Título & FHC omite as florestas ao abordar mudanças no clima \\
\hline & Subtítulo & Floresta X Reflorestamento \\
\hline $\begin{array}{l}\text { ENUNCIADO } \\
2\end{array}$ & Título & Presidente cita até Trótski em seu discurso \\
\hline $\begin{array}{l}\text { ELEMENTO } \\
\text { VERBO- } \\
\text { VISUAL }\end{array}$ & \multicolumn{2}{|c|}{$\begin{array}{l}\text { Foto do presidente FHC com a seguinte legenda: "FHC discursa durante almoço do } \\
\text { Fórum de mudanças climáticas." }\end{array}$} \\
\hline \multicolumn{3}{|r|}{ REPORTAGEM 2} \\
\hline \multirow{2}{*}{$\begin{array}{l}\text { ENUNCIADO } \\
1\end{array}$} & $\begin{array}{l}\text { Chapéu e } \\
\text { título auxiliar }\end{array}$ & $\begin{array}{l}\text { Antropologia: Índios tinham sistema sofisticado para pesca durante o } \\
\text { século } 17\end{array}$ \\
\hline & Título & Amazônia tinha fazenda de peixes \\
\hline $\begin{array}{l}\text { ELEMENTO } \\
\text { VERBO- } \\
\text { VISUAL }\end{array}$ & \multicolumn{2}{|c|}{ Mapa da região amazônica correspondente com o título "Onde fica" } \\
\hline \multicolumn{3}{|r|}{ ENUNCIADOS DE PUBLICIDADE } \\
\hline \multirow[b]{2}{*}{ PEÇA 1} & Produto & Serviço de internet banking do Banco Banespa \\
\hline & $\begin{array}{l}\text { Chamada } \\
\text { principal }\end{array}$ & $\begin{array}{l}\text { WAP BANKING BANESPA: você ligado ao Banespa a qualquer } \\
\text { hora e a qualquer lugar }\end{array}$ \\
\hline \multirow{2}{*}{ PEÇA 2} & Produto & Curso de graduação em Fonoaudiologia da PUC-SP \\
\hline & $\begin{array}{l}\text { Chamada } \\
\text { principal }\end{array}$ & "Fonoaudiologia na PUC. Venha ver porque todo mundo fala bem" \\
\hline
\end{tabular}

$\mathrm{Na} \mathrm{FO}$, cada enunciado corresponde a uma reportagem distinta, nem sempre havendo um nó remissivo que viabilize a relação entre os enunciados, o que pode anular os planos de remissão encontrados na FSP. A seguir, vejamos a reprodução dos enunciados da FO: 
Figura (11) Folha Online, 09 de novembro de 2000 - Reportagem (1), enunciado (1) 57

\section{ciência

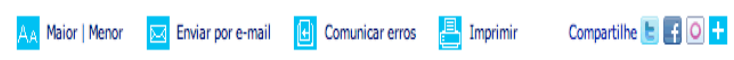

\section{FHC omite as florestas ao abordar mudanças no clima}

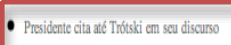

MARCELO LEITE, da Folha de S.Paulo

A cinco dias de começar mais uma rodada de negociaçōes sobre o clima mundial, em Haia (Holanda), o presidente Fernando Henrique Cardoso lançou oficialmente no Itamaraty o Fórum de Mudanças Climáticas. Falou até de gases produzidos pelo gado na sua digestão, mas evitou tocar na questão do desmatamento.

0 assunto é polêmico porque tem prevalecido no governo a tese de que florestas não devam entrar no chamado Mecanismo de Desenvolvimento Limpo (MDL).

Tema central em Haia, $0 \mathrm{MDL}$, quando regulamentado, será um modo de carrear recursos para páses pobres. Nações industrializadas investiriam em projetos de desenvolvimento no Terceiro Mundo capazes de evitar a produção de gases como o carbônico, que agravam o efeito estufa.

Havia uma menção ao tema no discurso impresso, omitida porém pelo presidente quando abordou o inventário das emissões locais de gases estufa:

"Ele) trará uma contribuição significativa para a metodologia da estimativa das emissõos num país tropical, com vastos setores agrícola e silvicultor. Nossa comunidade científica também desenvolve trabalhos relevantes em relą̧ão à modelagem numérica da mudança global do clima e à compreensão das interações entre a atmosfera e a biosfera em nosso teritório, notadamente na Amazônia", escreveu FHC.

Após destacar que o Brasil tem matriz energética "limpa",FHC afirmava no discurso distribuído: "Determinei a diferentes órgäos do governo que analisem todos os setores de atividade do país do ponto de vista da mudança do clima. 0 setor de silvicultura merece atenção especial pela sua potencialidade de contribuir para mitigar a concentraçăo dos gases de efeito estufa."

A inclusăo das florestas no MDLé defendida por setores minoritários no governo, como o Ministério do Meio Ambiente (MMA). A omissão presidencial pode, portanto, ser considerada indicativa de sua fraqueza.

Com $40 \%$ das florestas tropicais do mundo, 0 Brasil renuncia assim a fonte considerável de recursos, na casa de bilhões de dólares. Sem florestas, estima-se que o pás abocanharia no máximo $1 \%$ da receita com MDL.

Com a destruiçăo de 20 mil km2 de floresta por ano, em média, a Amazônia é hoje a maior fonte emissora de gases do efeito estufa no país. As estimativas variam, mas ela pode ser três vezes maior que o emitido com a queima de combustíveis fósseis.

\section{Floresta X reflorestamento}

Um seminário realizado por organizações não-governamentais em Belém, semana passada, defendeu num "Manifesto da Sociedade Civil" que recursos do MDL sejam destinados a projetos de manejo florestal. Essa exploraçăo racional da floresta pode cortar ao meio a derrubada pelo método tradicional, sem planejamento.

As conclusões do manifesto devem ser apresentadas hoje pelo ministro do Meio Ambiente, José Samney Filho, na primeira reuniäo do Fórum, na presença de FHC.

Terá de enfrentar a oposição do Ministério da Ciência e Tecnologia e do ltamaraty, formuladores da posição brasileira. 0 máximo que aceitam é incluir florestas plantadas no MDL.
C Acompanhe a Folha.com no Twitter tb

as últimas que vocênão leu

1. Marginal Tietê tem $5 \mathrm{~km}$ de lentidão no sentido Ayrton Senna

2. Juiz cita "lei de Gerson" e notifica shopping Pátio Higienópolis, em SP, para regulamentar documentação

3. Com desfalques, Dorival Júnior faz improvisações e altera esquema

4. Kathryn Bigelow visita Tríplice Fronteira para seu próximo filme

5. Ex-presidente do Congresso colombiano é preso por suposta ligação com milíias

6. Empresários brasileiros buscam ampliar relações com Colômbia

7. Ibope indica empate técnico entre Collor, Lessa e Teo Vilela em Alagoas

8. Cadeirinhas esgotam nas lojas e Salvador (BA) suspende multas

9. iphone 4 chega às lojas brasileiras na sexta-feira

10. Dilma vê 'factoide' na denúncia de nup Frenire teria viahilizarn nenńrin que Erenice teria viabilizado negocio nos Correios

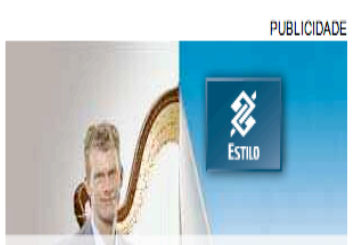

É um orgulho saber que meu cartão patrocina uma orquestra como essa.
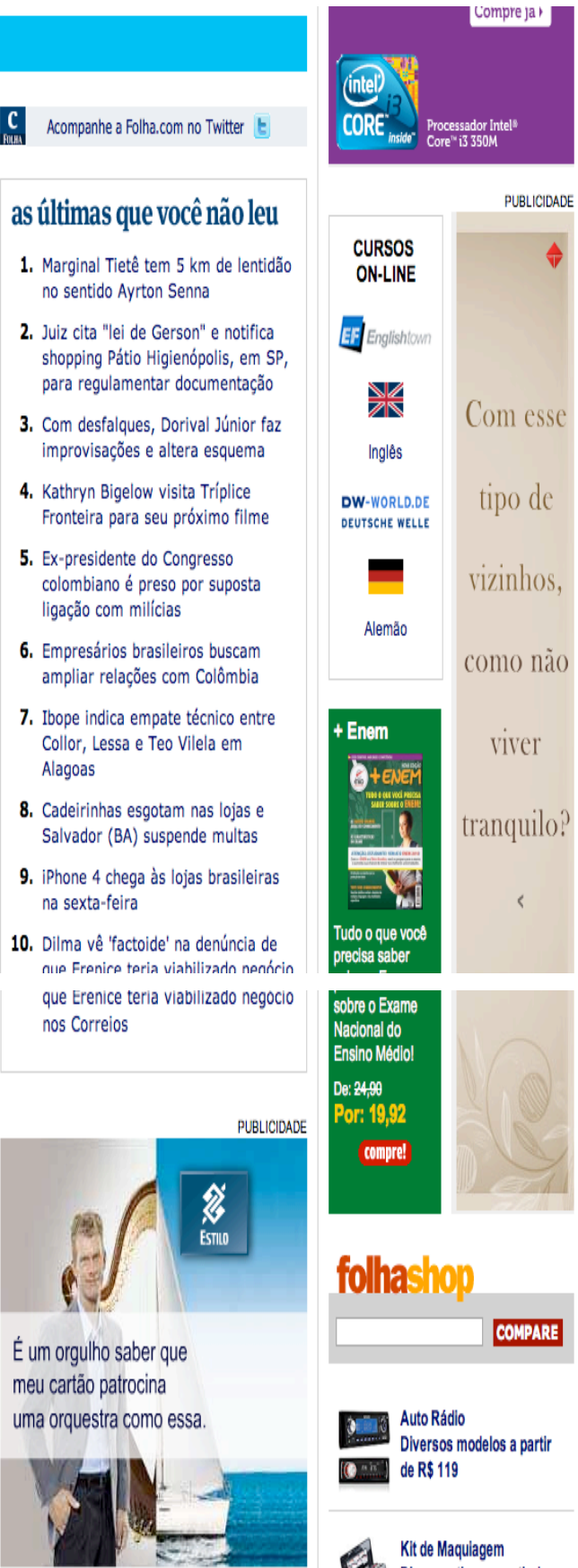

+ Enem

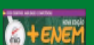

viver


2.7. Auto Rádio

Diversos modelos a parti

$\mathbf{O}^{-\mathrm{n}}$ de $\mathrm{R} \$ 119$

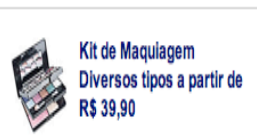

+lidas

1. Exame de sangue pode detectar Alzheimer, diz estudo

2. Cientista alerta sobre superbactéria resistente a quase todos antibióticos

3. Concurso para professor

\footnotetext{
${ }^{57}$ Disponível em: http://www1.folha.uol.com.br/folha/ciencia/ult306u991.shtml. Acesso em: 19/05/2009.
} 
Figura (12) Folha online, 09 de novembro de 2000 - Reportagem (1), enunciado (2) ${ }^{58}$

\section{$09 / 11 / 2000-04 h 53$}

\section{Presidente cita até Trótski em seu discurso}

- FHC omite as florestas ao abordar mudanças no clima

\section{da Folha de S.Paulo}

0 presidente Fernando Henrique Cardoso não se limitou a mencionar o gás metano arrotado por bois no almoço de lançamento do Fórum de Mudanças Climáticas. Citou também Karl Marx (1818-1883), no discurso escrito,e Immanuel Kant (1724-1804), na fala. Fez, ainda, alusões a Georg Wilhelm Friedrich Hegel (1770-1831), empregando a expressão "universal

concreto",e até a Leon Trótski (1879-1940).

Quando se referia ao princípio da responsabilidade comum, porém diferenciada, de países ricos e pobres sobre 0 clima, FHC usou expressão marxista: "A responsabilidade é desigual, mas não combinada". A referência algo cifrada foi à idéia de desenvolvimento desigual e combinado, do revolucionário Trótski no livro "A História da Revolução Russa", de 1932.

0 desenvolvimento desigual já era noção corrente entre marxistas para descrever o atraso de alguns países. Trótski acrescentou o "combinado" para captar o fato de que dentro de cada país menos desenvolvido o desenvolvimento também é desigual, combinando setores sociais avançados com outros atrasados.

(ML)

\footnotetext{
${ }^{58}$ Disponível em: http://www1.folha.uol.com.br/folha/ciencia/ult306u992.shtml. Acesso em: 19/05/2009.
} 
Figura (13) Folha online, 09 de novembro de 2000 - Reportagem (2), enunciado (1) 59

09/11/2000 - 04 h54

Amazônia tinha fazenda de peixes

\section{CLAUdio ANGelo, da Folha de S.Paulo}

Está cada vez mais difícil sustentar a tese de que a pobreza ambiental da Amazônia impediu o desenvolvimento de grandes sociedades indígenas na região no passado. Um estudo publicado hoje na revista "Nature" mostra que culturas do norte da Bolivia driblaram o ambiente, transformando a savana onde viviam numa piscicultura gigante.

Estudando aterros pré-colombianos na região de Baures, perto da fronteira com o Brasil, o arqueólogo norte-americano Clark Erickson, da Universidade da Pensilvânia, descobriu estar diante de um sistema de canais e tanques de $500 \mathrm{~km} 2$ de extensão (um pouco maior que a baía de Guanabara), provavelmente usado pelos índios para criar peixes.

A piscicultura, afirma o pesquisador, foi a maneira encontrada pelos antigos bolivianos para suprir a carência de proteínas num lugar onde a caça rareia e onde o solo é ruim para o plantio.

"Em vez de simplesmente se adaptar a um dado ambiente externo, os povos amazônicos construíram o ambiente que desejaram", disse Erickson à Folha.

A região de Baures, perto da fronteira com o Brasil, é uma zona de campos naturais que passa metade do ano alagada. Para aproveitar os peixes trazidos pelas cheias, os índios baures usaram um truque engenhoso: ergueram mais de $1.500 \mathrm{~km}$ de diques em forma de ziguezague, com "comportas" a cada 50 ou 100 metros.

Atrás de cada barreira eram construídos "piscinões" circulares, mais profundos, que acumulavam água nas épocas mais secas.

"Os peixes que entravam ficavam retidos ali e podiam ser capturados facilmente durante o resto do ano", afirma o cientista.

Os tanques acabavam tendo tripla função: além de prover água e peixe, ainda tornavam o solo adequado ao nascimento de palmeiras de frutos comestiveis. Para completar, eram ótimos pontos de caça. "Animais se juntavam ali para beber água", diz Erickson.

Para complementar a dieta, os baures cultivavam mandioca e batata-doce em aterros, sobre os quais também erguiam aldeias.

$(\ldots)$

De forma sucinta, a página analisada está disposta da seguinte forma: duas reportagens, sendo que a primeira é formada por dois enunciados e a segunda por um único; ambas as reportagens possuem elementos verbo-visuais; duas peças publicitárias que também são formadas por uma dimensão verbo-visual. Em meio a esses elementos, a

\footnotetext{
${ }^{59}$ Disponível em: http://www1.folha.uol.com.br/folha/ciencia/ult306u993.shtml. Acesso em: 19/05/2009.
} 
delimitação do enunciado-fonte, aquele a partir do qual as relações hipertextuais são geradas, torna-se evidente pelos aspectos da forma composicional visíveis na reprodução acima, como o maior espaço ocupado e título com fonte cujo tamanho é mais destacado em relação aos demais enunciados; bem como pela dimensão verbo-visual central para toda a página, aspecto discutido no terceiro item desta análise. A nosso ver, para entendermos as relações de sentido estabelecidas entre enunciados, necessitamos verificar quais são os nós remissivos linguísticos e extralinguísticos que fazem com que os enunciados sejam articulados de modo hipertextual.

A identificação do enunciado-fonte, que se refere ao primeiro enunciado da primeira reportagem, também foi possibilitada a partir do exame do 'Primeiro Caderno' como um todo, já que tanto o presidente FHC quanto a referência às questões climáticas haviam sido abordados anteriormente em outras páginas. Portanto, com base na delimitação do enunciado-fonte, pudemos identificar os seguintes planos de relações dialógicas hipertextuais, cujas funções são discutidas mais adiante:

- Plano interno primário: corresponde ao plano das relações dialógicas hipertextuais entre os elementos verbais e verbo-visuais de um mesmo enunciado, como observamos no enunciado-fonte "FHC omite florestas ao abordar mudanças no clima";

- Plano interno secundário: refere-se às relações dialógicas hipertextuais entre enunciados que formam a mesma reportagem. No caso, o enunciado-fonte une-se ao enunciado "Presidente cita até Trótski em seu discurso" para formar a reportagem principal;

- Plano externo primário: diz respeito às relações dialógicas hipertextuais entre uma reportagem com os demais enunciados da mesma página. No exemplo acima, consideramos que esse tipo de plano ocorre entre as reportagens 1 e 2 e as peças publicitárias;

- Plano externo secundário: depreendido das relações dialógicas hipertextuais entre enunciados de uma página a outra do jornal, cujo enunciado vinculado ao enunciadofonte pode, inclusive, pertencer a outra editoria ou a outro caderno.

O intuito do reconhecimento dos diferentes planos de remissão é mostrar a complexidade do caminho para a apreensão dos sentidos que emergem do encontro de 
diferentes enunciados nos meios impressos e digitais. Entretanto, a análise aprofundada das relações dialógicas hipertextuais dar-se-á gradualmente. Por hora, enfocamos a hipertextualidade presente no enunciado-fonte em ambas as versões.

A relação dialógica de oposição que primeiramente foi estabelecida entre a charge e a notícia sobre a recepção da reeleição de Bush é trazida para a arena do enunciado-fonte, linguisticamente marcada pela conjunção 'mas' logo no chapéu da reportagem: "Presidente lança fórum, mas não fala de recursos para Amazônia”.

Percebemos a presença de dois temas dominantes: o imperialismo econômico e a ameaça ao meio ambiente. O jornal explicita a relação adversa entre os dois temas ao salientar elementos do próprio discurso de FHC que ora utiliza expressões da esfera científica, tal como "modelagem numérica de mudança global no clima" e "compreensão das interações entre atmosfera e biosfera"; ora faz menção à esfera científica, como em "nossa comunidade científica"; mas que 'omite' e 'evita', segundo os termos do jornalista, a questão da sustentabilidade, não aleatoriamente, assunto central da segunda reportagem.

Além de identificar os objetos de sentido, observamos a hipertextualidade prevista na relação entre as dimensões verbais e visuais do enunciado-fonte. A forma composicional do enunciado é concretizada a partir da inserção de uma imagem fotográfica legendada do presidente com o seu discurso em mãos, centralizada no plano de expressão verbal do enunciado.

O plano de fundo da fotografia indica o lugar do qual fala o presidente, também identificado verbalmente, o Itamaraty. Se no texto é ressaltada a omissão em relação ao desmatamento, cuja menção estava prevista "no discurso impresso", na imagem o discurso aparece nas mãos do presidente. Assim o jornalista expressa verbalmente como FHC omite passagens do discurso, a fotografia reforça o fato de que FHC não olha para ele, não o lê. Portanto, o conteúdo temático depreendido da dimensão verbo-visual favorece uma relação dialógica hipertextual de plano interno primário com a dimensão verbal do enunciado cujo função é de convergência e reforço das imagens que circulam do ponto de vista do plano do conteúdo.

$\mathrm{Na} \mathrm{FO}$, não ocorre o mesmo tipo de relação dialógica hipertextual de plano primário interno. Todavia, a reprodução do texto tal e qual publicado na FSP é precedida pela materialização de um nó eletrônico que traz o título de outra reportagem. A reportagem representada, no caso, refere-se ao segundo enunciado da primeira reportagem da FSP. Com a ausência do chapéu que estabelece a fronteira entre reportagens, além de possuir a função discursiva de antecipação da adversidade encontrada a partir da oposição 'mercado versus 
floresta', deparamo-nos com uma rede de remissão de planos distinta. O enunciado-fonte da FSP é o mesmo na FO sob o ponto de vista da dimensão verbal, mas na FO o único plano de remissão encontrado foi ao enunciado articulado pelo nó eletrônico, como em destaque na figura (9), apresentada anteriormente.

Observamos que os enunciados da FO não são meras reproduções dos enunciados da FSP e que a hipertextualidade possui particularidades em cada meio. Epistemologicamente, é verdade que não poderíamos assumir os dois acontecimentos como enunciados reproduzidos, uma vez que a teoria bakhtiniana ressalta a individualidade da materialização do enunciado e seu caráter único na História.

A análise do enunciado-fonte da FO leva-nos a um caminho diferente do anterior e faz-nos pensar que a maior autonomia ou mesmo a falta de elementos 'autocontextualizadores' envolvendo os enunciados pode causar. Por elementos 'autocontextualizadores' referimo-nos aos próprios enunciados veiculados pelo jornal, tal como o editorial, as opiniões de autores e leitores e outros tipos enunciados. A particularidade do contexto de produção e circulação dos enunciados jornalísticos que participam obrigatoriamente de um contexto histórico e social que advém da realidade da vida é que o próprio jornal possui como uma de suas funções refletir e refratar os efeitos desse contexto imediato. Logo, os enunciados do jornal dialogam com os enunciados que emergem de outras esferas e são contextualizados por eles, mas também são contextualizados pelos próprios enunciados de sua esfera.

$\mathrm{Na} \mathrm{FO}$, por conta do volume de informações veiculadas e da própria instantaneidade típica da tecnologia que sustenta a internet, os enunciados não podem ser capturados da mesma forma, sob o ponto de vista composicional. Portanto, só conseguimos recuperar um enunciado por meio de outro se um deles possuir algum nó remissivo, no caso, o link eletrônico. A relação dialógica entre as reportagens, observada na disposição composicional do jornal impresso, pode passar despercebida pelo leitor digital caso ele acesse as reportagens separadamente. Somente se houver uma leitura mais ampla, ou seja, das demais reportagens publicadas naquele dia, o leitor tem a chance de apreender tais relações que, no jornal impresso, são estabelecidas pela disposição da página do jornal. Essa situação deve-se à própria tecnologia no que tange à interatividade e possibilidade de o leitor, em cada jornal, apreender seus respectivos enunciados.

Observando as reportagens digitais do ano de 2010, vemos que o processo é o mesmo: os enunciados fragmentados no jornal impresso só estão relacionados entre si por meio de link eletrônico no jornal online, quando fazem parte da mesma reportagem. Caso 
contrário, cabe ao usuário a leitura e a percepção das relações dialógicas entre as diferentes reportagens.

Retomando a análise da hipertextualidade no enunciado-fonte da FO, a relação dialógica hipertextual captada é a de que o enunciado vinculado reverbera os conteúdos temáticos da fonte, por meio do detalhamento de trechos do discurso do presidente. Tal relação dialógica, também observada no impresso, será discutida no item seguinte. Encerramos o primeiro momento de análise da reportagem refletindo sobre os possíveis planos de remissão da publicação digital.

Considerando a autonomia dos enunciados, no sentido em que cada enunciado equivale a uma reportagem, podemos considerar que a hipertextualidade aqui estabelecida é do plano exterior secundário, pois a remissão ocorre entre diferentes páginas da publicação. Lembramos que na FSP essa mesma relação equivale à remissão entre planos internos secundários, uma vez que enunciado-fonte e enunciado vinculado formam a mesma reportagem.

\subsubsection{A geração de temas a partir da relação hipertextual entre enunciados: da valorização da floresta ao descaso marcado na fala do presidente}

Conforme estabelecemos no item anterior, o enunciado-fonte da FSP possui um nível mais aprofundado no que tange às relações dialógicas. As suas dimensões verbal e verbovisual encontram-se em diálogo convergente de sanção crítica em relação ao presidente, figurativizado verbalmente e por meio da plasticidade da imagem fotográfica. Na FO não notamos a hipertextualidade em primeira instância, e encontramos somente uma ocorrência de relação dialógica hipertextual gerada por meio de nó eletrônico.

Se observarmos as relações de sentido estabelecidas na FSP, notamos que o tema resultante da relação dialógica entre a primeira reportagem e a segunda é a crítica à atuação do presidente FHC perante a problemática do meio ambiente. Tal tema é gerado a partir da relação entre as reportagens e seus elementos peritextuais, linguísticos e verbo-visuais, bem como da relação entre os temas de cada uma das duas reportagens.

Enquanto na primeira, a crítica ao presidente é direcionada de forma direta, com base na apresentação da problemática e na indicação de outros elementos menos importantes citados no lugar das medidas pró-reflorestamento, a segunda reportagem reforça a crítica de maneira indireta. $\mathrm{O}$ autor seleciona um fato do domínio da antropologia, disciplina das Ciências Sociais, área de formação do ex-presidente, para atribuir aspectos de valoração 
positiva ao objeto principal que sustenta a discussão, a Amazônia. $\mathrm{O}$ conteúdo temático da página abriga uma polêmica velada instaurada pelo discurso valorativo presente na segunda reportagem.

O discurso bivocal pautado em polêmica velada encontrado entre as reportagens da página está no enaltecimento dos valores positivos da floresta em contraponto com a valoração negativa dada ao agir do presidente/governo. A crítica é construída de modo indireto, sem que haja uma referência direta ao presidente FHC. No entanto, observamos a orientação crítica da segunda reportagem em relação à primeira, ao perceber o tema apreendido - a subsistência como algo favorável - e a área científica de concentração identificada no chapéu, a antropologia, sendo FHC um cientista social. A nosso ver, a Amazônia não é o único objeto de valor em evidência no discurso do jornalista, mas também o próprio saber do presidente como um intelectual da área de humanidades.

O segundo enunciado da primeira reportagem reforça o conhecimento do presidente a partir das referências a autores importantes da Ciência Política. Ao lermos os enunciados, percebemos que eles são direcionados enunciativamente para apontar o que o jornalista anunciou nos respectivos títulos, ou seja, "o presidente citou até Trótski ${ }^{60}$ em seu discurso", entre outros estudiosos e filósofos, empregou expressões teóricas atribuídas a eles, discorreu sobre aspectos históricos em relação ao desenvolvimento desigual, mas não falou do assunto mais aguardado tanto pelo jornalista quanto pelos leitores, o Mecanismo de Desenvolvimento Limpo (MDL) que não prevê a entrada das florestas brasileiras em seu plano de preservação. O jornalista deixa claro que o presidente buscou evitar a polêmica sobre um assunto considerado de importância para a opinião pública dos leitores do jornal, um dos de maior circulação no estado de São Paulo, bem como em todo o território nacional.

Ressaltamos que o advérbio "até" pode ser considerado um nó remissivo de natureza linguística, ao passo que sugere que o discurso do presidente havia sido mencionado anteriormente no enunciado-fonte. Trata-se de um caso em que não somente o enunciado a pode remeter a $\mathbf{b}$, mas que em que $\mathbf{b}$ remete igualmente $\mathbf{a} \mathbf{a}$.

Enquanto a primeira reportagem foi formulada com o objetivo de introduzir a questão, a segunda, sob o ponto de vista valorativo, reforça de forma positiva a floresta e de forma negativa a figura do presidente. Num primeiro momento, o título auxiliar da primeira reportagem já indica a tensão gerada pelo fato de o presidente não ter incluído a questão do

\footnotetext{
${ }^{60}$ Leon Trótski, nascido em 7 de novembro de 1879 em Ianovka e morto em 21 de agosto de 1940 na cidade de Coyoacán, foi um bolchevique e pensador marxista que fundou do Exército Vermelho na Rússia no final do século XIX.
} 
desmatamento em seu discurso: "Presidente lança fórum, mas não fala de recursos para a Amazônia”. Em seguida, mostra-se que o discurso do presidente é fundamentado não por ações que podem ser benéficas à floresta, mas sim por elementos de propriedade intelectual. Finalmente, o jornal apresenta uma faceta favorável da floresta a partir de um fato antropológico, o que termina por reforçar a adversidade entre a proposta política do governo e a expectativa da sociedade.

De certa maneira, a presença da segunda reportagem, que ressalta a importância da floresta para esses povos e a possibilidade de uma vida sustentável na floresta, agrava o que o jornalista apontou como falta cometida pelo presidente na primeira reportagem: o silenciamento no tocante às medidas tomadas em relação à floresta. A voz do jornalista, mais do que expressar uma perplexidade pessoal, visa atender às expectativas de seu leitor presumido que, provavelmente, também incomodar-se-ia com a postura do presidente / governo perante as medidas (não) tomadas em relação à preservação das florestas.

Até o momento, a análise faz-nos notar que o dialogismo hipertextual é, sobretudo, favorecido pela estruturação modular dos planos de enunciados na forma composicional das reportagens impressas e principalmente favorecido pela articulação em nós remissivos presentes na forma composicional das reportagens digitais. Apesar de apresentar uma fragmentação maior, a hiperestrutura propicia a constituição de um enunciado maior, formado a partir dos enunciados e seus próprios temas.

Os enunciados ligados por nós remissivos eletrônicos dificilmente fazem o mesmo e os temas dependem muito mais do percurso de leitura de cada usuário por dois motivos: primeiro, ele pode optar por acessar o outro enunciado ou não e, segundo, nem sempre o outro enunciado é diretamente relacionado ao enunciado fonte. No jornal impresso, o leitor também escolhe que textos irá ler e qual a linearidade de sua leitura. Porém, a unidade de sentido do enunciado maior já está dada, ou seja, há uma proposta enunciativa e axiológica mais coesa, materializada na disposição dos elementos verbais e verbo-visuais na página.

Pensar as relações dialógicas hipertextuais implica em evidenciar a função dialógica do nó remissivo. Assim como em meio digital, o nó articula remissões cujas relações dialógicas podem ser de diversas ordens. Os títulos, geralmente, são nós remissivos potenciais, pois a indexação de enunciados, tanto na primeira página de um jornal, em um sumário, ou na página principal de um portal digital, é feita por meio deles. No caso das reportagens que analisamos, dispostas em um mesmo plano espacial, pode haver a impressão de que tal indexação não ocorre. No entanto, quando recorremos aos enunciados na FO, verificamos que ambos estão relacionados por meio de um nó eletrônico. 
$\mathrm{O}$ que difere entre as publicações são as relações dialógicas hipertextuais que emergem a partir de percursos de leitura distintos. A relação dialógica de complementariedade bem marcada no impresso pode vir a se perder no digital. $\mathrm{O}$ mesmo ocorre na relação entre a primeira reportagem e a segunda. Se no impresso a relação dialógica entre elas só é evidente a partir do momento em que apreendemos o tema, ou a realidade ali refletida e refratada, no digital essa relação é perdida, mais uma vez. Não há qualquer nó que permita o encontro entre os dois enunciados.

\subsubsection{A hipertextualidade na dimensão verbo-visual dos enunciados impressos}

Os elementos verbo-visuais da página entram em relação dialógica com os enunciados verbais, no entanto isso ocorre em duas instâncias. Tanto a fotografia do presidente na primeira reportagem, quanto o mapa ilustrativo da segunda podem ser considerados uma dimensão verbo-visual situada nos enunciados ao qual pertencem. Já os anúncios publicitários que compõem a página configuram-se como enunciados distintos. Em 2000, a dimensão verbo-visual dos enunciados não é autônoma como iremos observar nos anos seguintes. $\mathrm{O}$ argumento da imagem está estritamente relacionado aos elementos verbais do enunciado como discutimos na primeira parte da análise sobre o enunciado-fonte.

A imagem fotográfica do presidente FHC segurando seu discurso, centralizada e destacada na página do dia 09/11/2000 estabelece relação dialógica não somente com a dimensão verbal do enunciado-fonte e peritextual, mas também com todos os outros elementos de dimensão verbo-visual, inclusive os anúncios publicitários. 


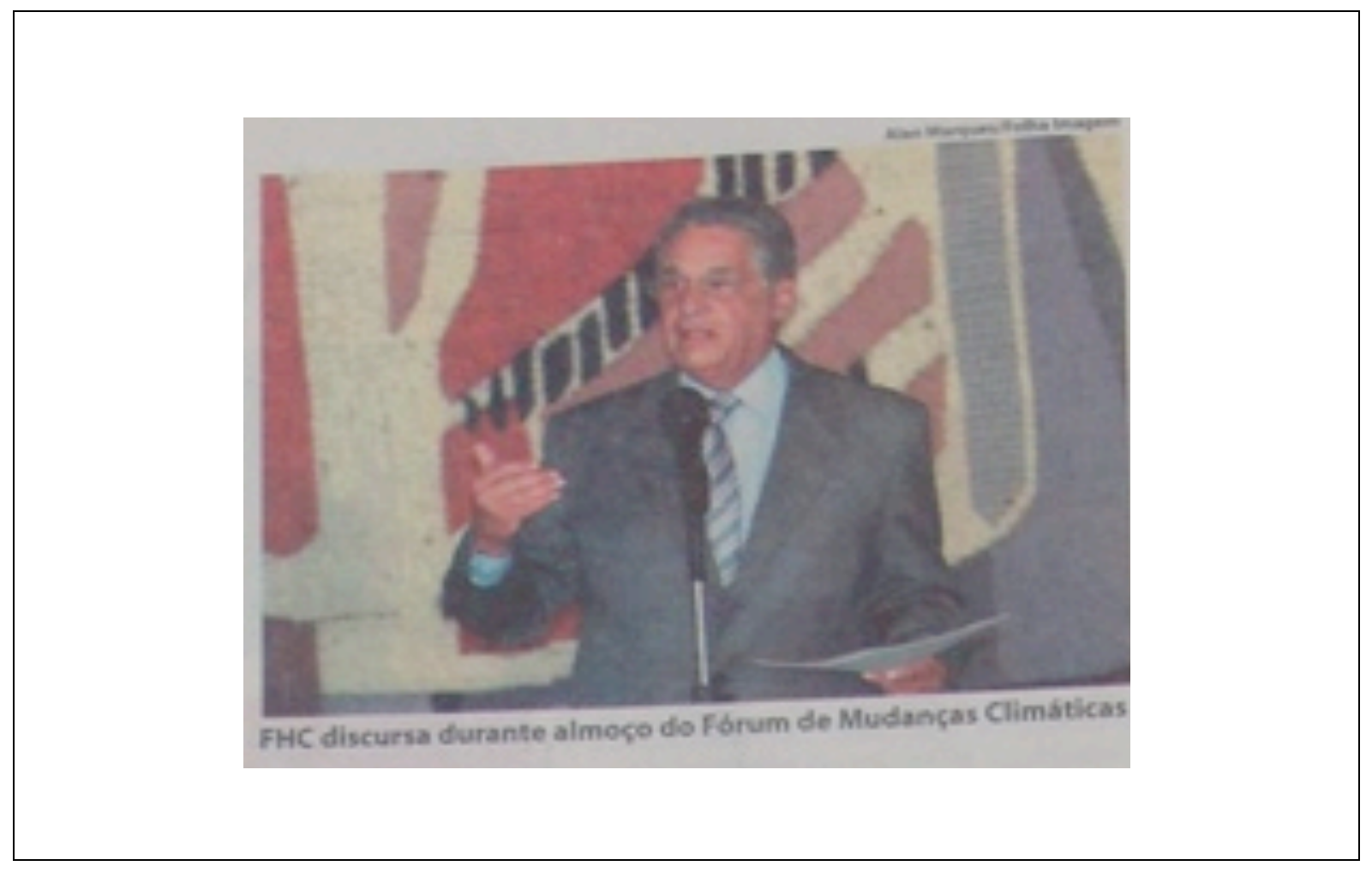

Antes de elaborarmos o esquema da relação dialógica interplanos suscitada entre os elementos verbo-visuais da página algo nos chama a atenção no tocante à fotografia de FHC. Assim como o discurso do cientista que é recuperado com o intuito de atribuir credibilidade aos argumentos apresentados na reportagem, a imagem tanto da figura estereotipada do cientista - jaleco branco, tubos de ensaio e laboratório - ou mesmo uma reprodução fiel de sua face, também é elemento recorrente no discurso de DC.

Em um estudo sobre a representação do corpo exterior do cientista em seu corpus, Grillo (2009) conclui que "a representação do cientista e de seu espaço de trabalho permite a transferência da noção de cronotopo (...) do romance para a reportagem de divulgação científica" (p.236). No caso de nossa análise, o tempo e espaço podem ser representados pelo momento em que FHC é presidente e governa no período de seu mandato e pelo espaço do Itamaraty $^{61}$, local de realização de pronunciamentos da esfera política. A caracterização do cronotopo, cujos elementos da esfera política, expressa um deslocamento do cronotopo observado em reportagens de DC, ou seja, o discurso político chega a sobressair-se em relação ao discurso científico na esfera jornalística cujos enunciados circulam entre um

\footnotetext{
${ }^{61}$ O Palácio do Itamaraty sedia o Ministério das Relações Exteriores brasileiro na capital federal, Brasília.
} 
público presumido heterogêneo e de não especialistas. No plano da expressão, a imagem do presidente revela o discurso político. Ainda no início da década, até mesmo a editoria de ciência parece constituir-se como uma arena para os entraves e debates políticos.

Não somente a fotografia estabelece uma relação dialógica com o enunciado-fonte em plano interno primário, mas também há uma relação com o segundo e o terceiro enunciado, apesar deste último fazer parte de outra reportagem. A posição ocupada pela fotografia é central para a página e revela uma relação com todos os elementos de dimensão verbo-visual que a compõem, incluindo os anúncios publicitários, como assinalamos na próxima figura: 
Figura (15) A hipertextualidade na dimensão verbo-visual em novembro de 2000

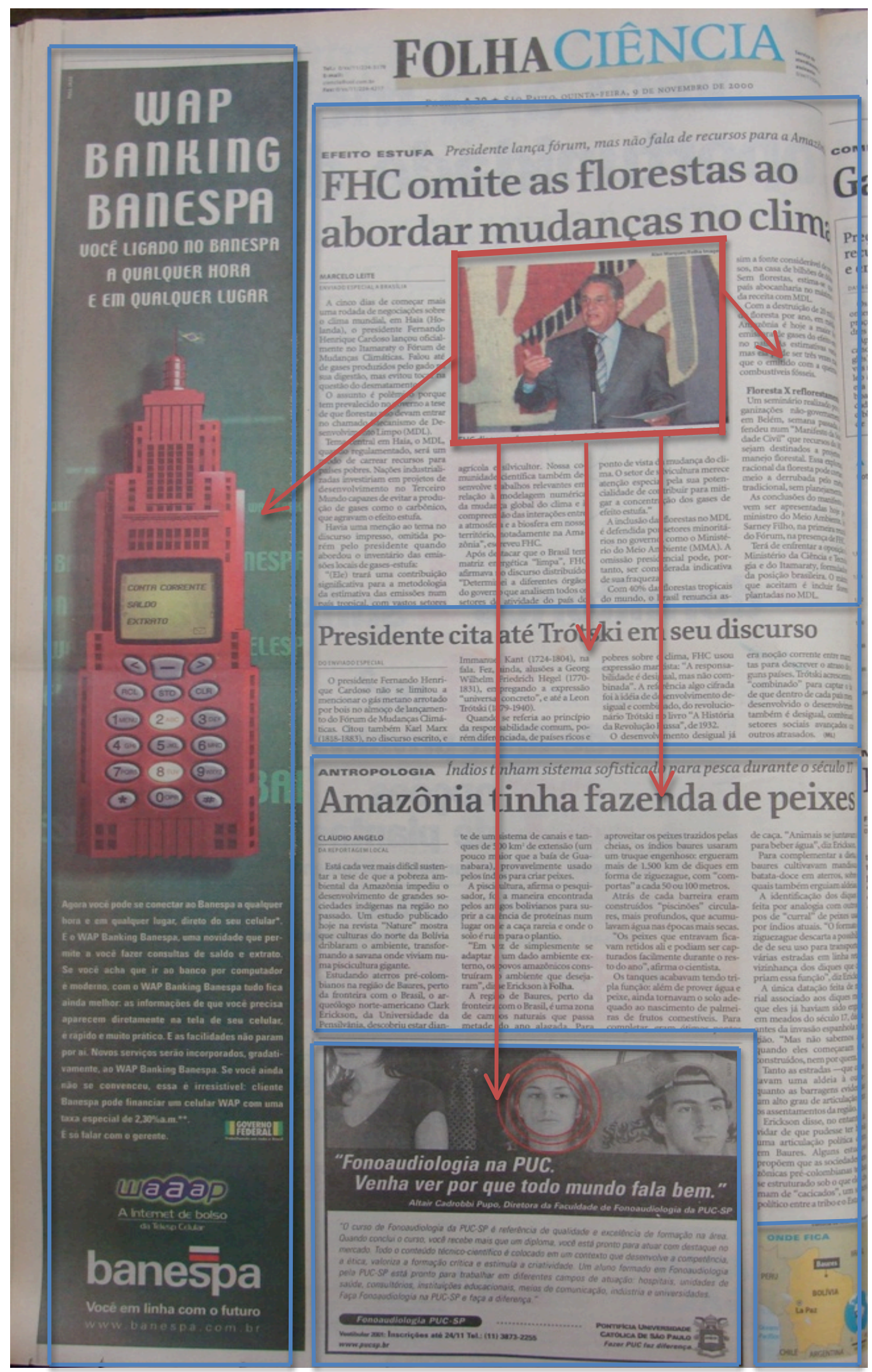


Analisando as imagens da página isoladamente temos: (i) a representação do prédio do antigo banco BANESPA, edifício mais alto da cidade com o maior poder econômico da América Latina, São Paulo; (ii) a fotografia do presidente de origem paulista; (iii) a imagem de uma jovem estudante, cuja face é sublinhada por tinta vermelha, como se fosse um alvo e, finalmente, (iv) um mapa reduzido da região da floresta Amazônica, anteriormente habitada por nativos que cultivavam uma prática de vida autossustentável.

Diante deste quadro, considerando apenas o plano de expressão, podemos identificar a oposição entre o capitalismo e um modelo de subsistência, o que confirma o que havíamos identificado nas seções anteriores. Entretanto, é curioso que o mesmo agente responsável pelo argumento crítico contra os anseios capitalistas do presidente, não somente é regido pelas mesmas regras mercadológicas, como também propicia, por meio da abertura de espaço publicitário, o reforço da ideologia capitalista - mercantilista do governo naquela época.

A imagem do presidente apresenta uma relação remissiva de plano interno primário com o enunciado 1 ou o que temos denominado enunciado-fonte; relação remissiva de plano interno secundário com o enunciado 2 ou enunciado vinculado ao enunciado-fonte; relação de plano externo primário com a segunda reportagem e com as peças publicitárias; e relação de plano externo secundário com os enunciados apresentados no início do capítulo.

Os elementos peritextuais formados pelos títulos, chapéus e subtítulos de toda a página também entram em relação dialógica por meio da dimensão verbo-visual da página. $\mathrm{O}$ engendramento dos elementos peritextuais que participam da dimensão verbo-visual funcionam como uma síntese das relações dialógicas entre os enunciados. Apesar de possuírem perspectivas enunciativas distintas, o segundo enunciado sobre a sustentabilidade é uma continuidade que reforça os valores críticos apontados nos enunciados sobre a atuação omissa do presidente no momento do discurso.

Quase como uma narrativa, tais elementos auxiliam na demarcação do continuum traçado na composição da página que vai do 'Efeito estufa' à sustentabilidade na floresta, fato que é reforçado com o tempo passado empregado nos títulos da segunda reportagem como notamos na tabela (7) que será apresentada em seguida: 
Tabela (7) Elementos peritextuais da página da Folha de S. Paulo, 09 de novembro de 2000.

\begin{tabular}{|c|c|c|}
\hline \multicolumn{3}{|r|}{ REPORTAGEM 1} \\
\hline \multirow{2}{*}{$\begin{array}{l}\text { ENUNCIADO } \\
1\end{array}$} & $\begin{array}{l}\text { Chapéu e } \\
\text { título auxiliar }\end{array}$ & $\begin{array}{l}\text { Efeito Estufa: Presidente lança fórum, mas não fala de recursos para a } \\
\text { Amazônia }\end{array}$ \\
\hline & Título & FHC omite as florestas ao abordar mudanças no clima \\
\hline $\begin{array}{l}\text { ENUNCIADO } \\
2\end{array}$ & Título & Presidente cita até Trótski em seu discurso \\
\hline \multicolumn{3}{|r|}{ REPORTAGEM 2} \\
\hline \multirow{2}{*}{$\begin{array}{l}\text { ENUNCIADO } \\
1\end{array}$} & $\begin{array}{l}\text { Chapéu e } \\
\text { título auxiliar }\end{array}$ & $\begin{array}{l}\text { Antropologia: Índios tinham sistema sofisticado para pesca durante o } \\
\text { século } 17\end{array}$ \\
\hline & Título & Amazônia tinha fazenda de peixes \\
\hline
\end{tabular}

O fato de que a Amazônia 'tinha' um sistema sofisticado para pesca, bem como uma fazenda de peixes, expressa que tais elementos não existem mais, sendo que o efeito estufa e o desmatamento desenfreado permitido pelo governo podem ser entendidos como os agentes causadores da devastação.

\subsubsection{Síntese}

Na primeira análise, pudemos notar que os jornais possuem diferentes mecanismos de remissão, sendo que a hipertextualidade é articulada pelo aparecimento no nó eletrônico na FO e por meio de recursos verbo-visuais e linguísticos na FSP. A hiperestrutura da FSP coloca os enunciados em relação dialógica hipertextual, num mesmo plano de remissão. Por não se configurar bidimensional, o meio digital favorece a hipertextualidade somente em planos externos, primários ou secundários, isto é, todo o nó remissivo apontará para um enunciado que pertence a outra página do próprio portal de notícias ou de um site externo.

Os elementos estilísticos-composicionais também diferem do ponto de vista da forma em que os enunciados são materializados. A dimensão verbo-visual presente na FSP não é observada na FO, a não ser por conta dos elementos peritextuais pertinentes ao gênero reportagem, aspecto mantido no meio digital. A tematicidade relativa a cada enunciado e o juízo de valor imbricado em cada enunciado da FSP são mantidos na FO. Contudo, perde-se a tematicidade formada pela relação dialógica entre as reportagens 1 e 2. Se no impresso, a 
reportagem 2 traz uma informação nova para rechaçar ainda mais o presidente, tal como feito na primeira, o jornal digital não estabelece a mesma relação.

No escopo das reportagens da FSP, identificamos previamente uma relação dialógica de polêmica velada, refletida e refratada na relação entre as reportagens 1 e 2 . A polêmica é confirmada na primeira linha do texto (da segunda reportagem), quando o autor afirma que "está cada vez mais difícil sustentar a tese de que a pobreza ambiental da Amazônia impediu o desenvolvimento de grandes sociedades indígenas na região no passado". A partir do excerto, podemos nos perguntar sobre quem é o agente que sustenta a tese e logo fazer a relação com o presidente. Na FO, a orientação para o outro objeto discursivo é mantido, no entanto, o agente que sustenta a tese não é claro ao leitor. Constatamos que a disposição dos enunciados em um mesmo plano de remissão constitui-se espaço para o desenrolar da polêmica aberta na FSP, na medida em que a autonomia e a falta de articulação entre os enunciados da FO, favorecem um polêmica velada.

A hipertextualidade, no primeiro ano de análise, gera uma relação dialógica cuja função é de criar um tema único que reflete e refrata o posicionamento crítico do jornal FSP em relação à ação antissustentável do governo brasileiro representado pelo presidente FHC. $\mathrm{O}$ enunciado fonte - o primeiro enunciado que compõe a primeira reportagem, FHC omite as florestas ao abordar as mudanças no clima - vincula-se ao demais por meio de outros dois tipos de relação dialógica: com o segundo enunciado da mesma reportagem há concordância em relação à crítica do enunciado-fonte por meio da exaltação da erudição da fala do presidente, mascarando as implicações climáticas que as medidas governamentais podem surtir. O advérbio 'até' presente no título da segunda reportagem - Presidente cita até Trótski em seu discurso - carrega o pressuposto de que outros teóricos haviam sido citados no discurso do presidente, ao qual a polêmica aberta está direcionada no primeiro enunciado.

Para reforçar o posicionamento crítico do jornal em relação ao discurso de FHC, a FSP valeu-se de uma segunda reportagem que não atacava diretamente a figura do presidente e a falta de ação em relação ao reflorestamento. Ao contrário, a reportagem exalta as qualidades de outra personagem, a floresta Amazônica, como estratégia para reforçar a denúncia. Por meio de uma polêmica velada, a editoria modifica o eixo temático, deslocando-o sem, contudo, deixar de atacar o objeto do discurso anterior. A configuração hipertextual é dada em diferentes níveis na página do jornal impresso: as delimitações da estrutura composicional e verbo-visual delimitam o enunciado-fonte, em que a foto do presidente com o discurso é central. A centralidade da fotografia legendada e o cronotopo que ela representa - o presidente e seu discurso situados em um espaço legitimador do poder 
público, o Itamaraty, precedendo o advento da Convenção sobre o Clima - constituem um nó remissivo que unifica o conteúdo temático de toda a página. Até mesmo os anúncios publicitários participam da rede hipertextual.

Os demais elementos da dimensão verbo-visual, como os títulos, subtítulos e chapéus reforçam a relação dialógica entre as reportagens (1) e (2) por meio de um jogo de ocultamento e evidenciação das personagens-chave do evento. Na primeira, cujo chapéu e título auxiliar são Efeito Estufa: Presidente lança fórum, mas não fala de recursos para a Amazônia - a floresta ${ }^{62}$ é omitida do discurso do presidente, como observamos no segundo período introduzido pela conjunção adversativa 'mas'. Enquanto isso, a segunda reportagem faz a floresta aparecer, ocultando o presidente cuja presença está contida na área de concentração do chapéu, não coincidentemente a mesma área de formação de FHC: 'antropologia'.

No que tange aos anúncios publicitários, somente um está em confluência e participando do mesmo eixo temático central da página. Conforme relatamos anteriormente, o anúncio do BANESPA, que atravessa a página de ponta a ponta, representa o modelo econômico capitalista que historicamente é um dos responsáveis pela dizimação do patrimônio natural do planeta. Do anúncio, depreendemos dois aspectos: o banco, enquanto representante da força econômica do regime capitalista, traz o carimbo tanto do governo estadual quanto federal, ou seja, é do domínio do presidente e não da floresta; além disso, o anúncio visa a divulgar os serviços do banco via internet, o que evidencia que o leitor presumido da publicação, em sua maioria, possui acesso à internet.

$\mathrm{O}$ leitor que acessa a internet também pode encontrar as mesmas reportagens na FO, mais especificamente, a mesma forma lógica das reportagens da FSP. Os enunciados, únicos em sua concretização, diferem no tocante à estrutura composicional, ao conteúdo temático e à hipertextualidade. O jornal em meio digital permite que somente uma reportagem seja expandida em cada página. Empregamos o termo 'expandida', pois outros enunciados são presentificados na página sob forma de nó eletrônico. Logo não há hipertextualidade na relação entre os elementos verbo-visuais compostos pelo peritexto, além de não haver a presença da fotografia do presidente em nenhuma das reportagens. Com isso, as relações dialógicas hipertextuais são geradas pela articulação das reportagens, somente pelos nós eletrônicos.

\footnotetext{
${ }^{62}$ Neste caso, os termos 'floresta' e 'presidente' são metonímicos, uma vez que o primeiro remete a todas as questões relacionadas à sustentabilidade, preservação e aplicação de recursos à floresta amazônica, enquanto o segundo às medidas políticas adotadas pelo governo.
} 
A relação dialógica de polêmica velada encontrada na FSP não se mantém na FO, já que não há nenhum tipo de nó entre os enunciados da primeira reportagem com o enunciado da segunda. A relação dialógica hipertextual de concordância como reforço do argumento do enunciado-fonte é preservada entre os dois enunciados da primeira reportagem, que trazem os títulos uma da outra sob forma de nó eletrônico logo abaixo do título de cada reportagem.

\section{2 'Racha na economia' nacional e a ascensão americana na guerra contra o terror: implicações para os avanços científicos no ano de 2003}

Iniciamos a seção contextualizando os enunciados sócio-historicamente no plano dos acontecimentos mundiais da época. Os atentados de 9/11 culminaram em uma série de medidas reativas por parte dos EUA como a guerra travada contra o Iraque, cujo início deuse em março de 2003. O envio das tropas americanas ao território iraquiano foi o assunto mais comentado no mês de novembro do mesmo ano. O governo de George W. Bush investia milhões de dólares na "guerra contra o terror", em resposta aos ataques à Nova York e Washington dois anos antes. A sociedade americana parecia esperar uma reação do governo na busca pelos terroristas responsáveis pelos ataques coordenados pelo líder político e religioso Osama Bin Laden. Mesmo dois anos mais tarde, os EUA ainda configuravam a nação mais rica e poderosa do planeta e as sanções contra o Iraque foram aprovadas pela população. O lastro de indignação também havia tomado países como o Brasil, cuja mídia voltou-se para a incessante cobertura do caso.

Nos noticiários brasileiros, o acidente da base de Alcântara, em São Luís do Maranhão, ocorrido em agosto do mesmo ano, ainda rendia espaço para repercussões. A perplexidade girava em torno da falha no momento do lançamento do satélite que acabou matando 21 técnicos que se encontravam na base naquele momento. Durante todo o mês, observando o panorama geral de reportagens publicadas, o foco principal foi a corrida espacial, não somente no âmbito brasileiro, mas também internacional. No entanto, enquanto pudemos verificar que os avanços apontados nas reportagens foram creditados, em sua maioria, à União Europeia, EUA, Rússia e China, os eventos relacionados ao Brasil correspondiam à identificação de alguma falha, seja de ordem técnico-científica ou política.

Não por acaso, o secretário do Ministério de Tecnologia e Ciência deixava o cargo no início do mês, enquanto o governo anunciava que as causas do acidente em Alcântara não seriam levadas a público. Dentre as reportagens com valoração entonativa crítica, encontradas tanto na FSP quanto na FO, podemos destacar as seguintes: "Instituto de 
cosmologia cria 'racha' no CBPF" (03/11/2003); "Instituto de cosmologia nacional nunca foi 'virtual', diz seu criador" (04/11/2003); "Secretário executivo deixa cargo no MTC" (07/11/2003); "Astronauta brasileiro defende a investigação aberta de acidentes" (12/11/2003); "Investigação do VLS-1 pode ser prorrogada" (17/11/2003); "Relatório de acidente com reator pode não ser público" (22/11/2003); "Mary Allegretti deixa Ministério do Ambiente" (29/11/2003).

Enquanto as reportagens voltadas ao Brasil procuravam destacar fatos desastrosos da esfera política que culminaram na ação mal sucedida em Alcântara, durante todo o mês, pudemos observar os avanços creditados a vários outros países, não somente na área cosmológica, mas também em outras, como a genética. Ao contrário do forte caráter político do discurso de DC analisado na primeira reportagem, os temas da esfera política estão ainda presentes, porém mais voltados para os interesses da esfera e da comunidade científica. As questões políticas mobilizadas estão estreitamente relacionadas ao momento econômico do país, como observamos a partir do enunciado a seguir:

Figura (16) Enunciado publicado no editorial da FSP no dia 25/11/2003

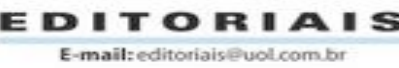

\section{RACHA NA ECONOMIA}

\begin{abstract}
POLARIZAC̨Ão que acontecen $A$ no governo Fernando Henrique Cardoso entre os economistas chamados de "desenvolvimentistas" e a equipe econômica liderada pelo ministro da Fazenda, Pedro Malan. também vai se reproduzindo na gestāo Luiz Inácio Lula da Silva. De mo do esquemático, na era FHC, Malan era visto pelos oponentes como o centro irradiador de uma política liberal ortodoxa, que veio a se voltar para a formação de superávits fiscais com vistas a administrar o endividamento público e a confiança dos mercados financeiros mundiais.

Em contraste, economistas como Luiz Carlos Mendonça de Barros. Luiz Carlos Bresser Pereira e José Serra, em que pesem as diferenças entre eles, coincidiam em enfatizar políticas de crescimento e maior ativismo por parte do governo.

A entrevista com o vice-presidente do BNDES, Darc Costa, na Folha de domingo, deixa claro que cisão semelhante está instaurada no atual governo. Tendo como superior Carlos Lessa, um desenvolvimentista
\end{abstract}

histórico, o entrevistado contrapôsse ao ministro Antonio Palocci, da Fazenda, e ao responsável pelo Tesouro, Joaquim Levy - cujo órgão foi por ele designado ironicamente de "secretaria da tesoura". "Somos desenvolvimentistas. (...) A Fazenda, não", disse Costa à Folha.

Muito desse desencontro emergiu com a compra de açōes da Vale pelo BNDES, o que gerou desconforto na Fazenda e em outras áreas do governo. E certo que Palocci e Lessa estão em rota de colisão e que o antagonismo envolve outros ministros. Essa tensão reflete em parte o debate nacional e os impasses da economia, ou seja, a urgência de crescer e os limites impostos a esse objetivo pelo endividamento e pelos mercados financeiros internacionais.

Resta saber até que ponto o conflito poderá - como seria desejável- se revelar produtivo $e$ conciliável num ambiente econômico menos restritivo. Caso isso não ocorra, não é difícil prever o desfecho. Salvo desastre, $\mathrm{Pa}$ locci, como Malan, parece ser o lado mais forte da queda-de-braço. 
O excerto destacado do enunciado acima trava uma relação dialógica hipertextual de plano externo secundário com um outro enunciado na página do dia 25 de novembro, como verificaremos adiante na análise. A tematicidade que observaremos em seguida na análise é guiada pela tensão refletida pelo "debate nacional e os impasses da economia, ou seja, a urgência do crescer e os limites impostos a esse objetivo pelo endividamento e pelos mercados financeiros internacionais". Trata-se de uma crítica de valores econômicos e sociais no âmbito nacional que será desenvolvida pelos autores das reportagens.

\subsubsection{Aspectos estitístico-composicionais do corpus}

Nessa seção, apresentamos os enunciados selecionados no ano de 2003 representados pela imagem e pelo respectivo gráfico referentes à FSP, seguidos pelas figuras reproduzidas da FO abaixo - sob o ponto de vista de suas características estilísticocomposicionais. Especificamente, observamos a descrição da hiperestrutura do jornal impresso, recorrência dos nós remissivos em cada meio e os planos de remissão encontrados. 
Figura (17) Folha de S. Paulo, 25 de novembro de 2003

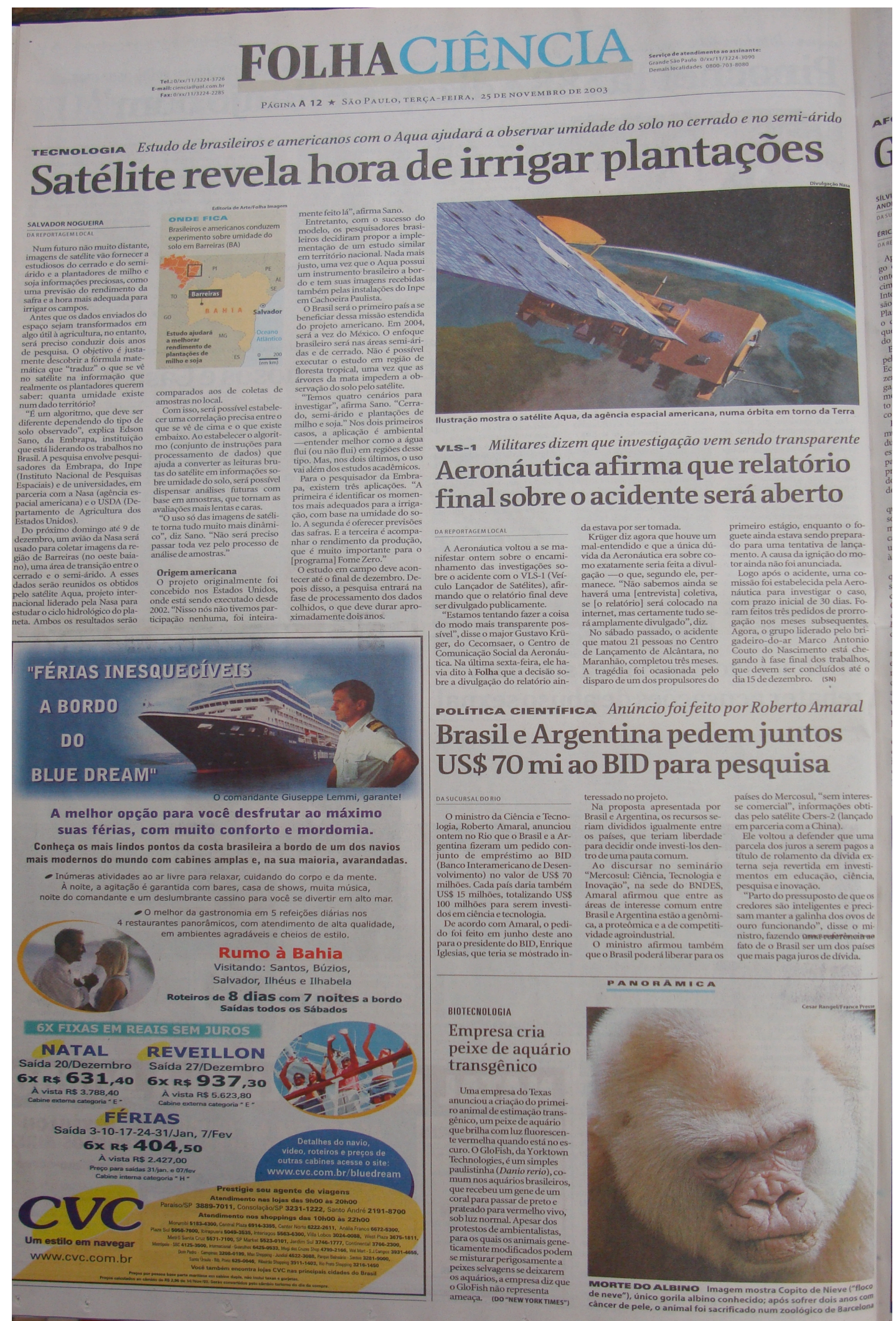


Tabela (8) Hiperestrutura da Folha de S. Paulo, 25 de novembro de 2003

\begin{tabular}{|c|c|c|}
\hline & & REPORTAGEM 1 \\
\hline \multirow{3}{*}{$\begin{array}{l}\text { ENUNCIADO } \\
1\end{array}$} & $\begin{array}{l}\text { Chapéu e } \\
\text { título auxiliar }\end{array}$ & $\begin{array}{l}\text { Tecnologia. Estudo de brasileiros e americanos como o Acqua ajudará a } \\
\text { observar a humidade do solo no cerrado e no semi-árido }\end{array}$ \\
\hline & Título & Satélite revela a hora de irrigar as plantações \\
\hline & Subtítulo & Origem americana \\
\hline $\begin{array}{l}\text { ELEMENTOS } \\
\text { VERBO- } \\
\text { VISUAIS }\end{array}$ & \multicolumn{2}{|c|}{$\begin{array}{l}\text { (1) Mapa identificando a região mencionada na reportagem com o título "Onde fica”. (2) Foto } \\
\text { do satélite com a seguinte legenda: “ Ilustração mostra a foto do satélite Acqua, da agência } \\
\text { espacial americana, numa órbita em torno da Terra". }\end{array}$} \\
\hline \multirow{2}{*}{$\begin{array}{l}\text { ENUNCIADO } \\
2\end{array}$} & $\begin{array}{l}\text { Chapéu e } \\
\text { título auxiliar }\end{array}$ & VLS-1. Militares dizem que investigação vem sendo transparente \\
\hline & Título & Aeronáutica afirma que relatório sobre o acidente será aberto \\
\hline \multicolumn{3}{|r|}{ REPORTAGEM 2} \\
\hline \multirow{2}{*}{$\begin{array}{c}\text { ENUNCIADO } \\
1\end{array}$} & $\begin{array}{l}\text { Chapéu e } \\
\text { título auxiliar }\end{array}$ & Política Científica. Anúncio foi feito por Roberto Amaral \\
\hline & Título & Brasil e Argentina pedem juntos US\$70 mi ao BID de pesquisa \\
\hline \multicolumn{3}{|r|}{ REPORTAGEM 3} \\
\hline \multirow{2}{*}{$\begin{array}{l}\text { ENUNCIADO } \\
1\end{array}$} & $\begin{array}{l}\text { Chapéu e } \\
\text { título auxiliar }\end{array}$ & Panorâmica. Biotecnologia \\
\hline & Título & Empresa cria peixe de aquário transgênico \\
\hline $\begin{array}{l}\text { ELEMENTO } \\
\text { VERBO - } \\
\text { VISUAL }\end{array}$ & \multicolumn{2}{|c|}{ Fotolegenda sobre a morte de um macaco albino. } \\
\hline \multicolumn{3}{|r|}{ MÓDULO DE PUBLICIDADE } \\
\hline \multirow{2}{*}{ PEÇA 1} & Produto & Pacotes de viagem da empresa CVC. \\
\hline & $\begin{array}{l}\text { Chamada } \\
\text { principal }\end{array}$ & Férias inesquecíveis a bordo do Blue Dream. \\
\hline
\end{tabular}

Das reportagens selecionadas para análise, a página impressa no ano de 2003 é uma das mais complexas sob o ponto de vista hiperestrutural. As três reportagens compõem uma página bastante fragmentada, com várias inserções peritextuais, tais como título, título auxiliar, lide, legendas e elementos de ordem verbo-visual. A reportagem principal é 
formada por dois enunciados, aparentemente autônomos, sob o ponto de vista do acontecimento do qual tratam, mas certamente guardam uma relação dialógica, sobretudo do ponto de vista temático, como veremos a seguir.

A segunda reportagem é composta por um só enunciado e resvala na questão política de forma direta, acompanhada do título auxiliar "Política científica". É exatamente este fato que a relaciona com os primeiros enunciados que tratam de questões de fundo político, sem explicitar ou incluir referências diretas à esfera política. A página encerra-se com um quadro de pequenas notícias, sem aprofundamento reflexivo ou ligação de ordem política, mas com características de curiosidades ou conhecimento geral. A peça publicitária encontrada referese a uma viagem de cruzeiro promovida por uma famosa agência de viagens brasileira.

$\mathrm{Na}$ versão digital, tivemos acesso à primeira reportagem da FSP com seus dois enunciados - que configuram duas reportagens distintas na $\mathrm{FO}$-, bem como à segunda reportagem. Não há qualquer ligação entre os enunciados da reportagem (1), nem mesmo sob forma de link eletrônico, ou seja, a relação entre os dois enunciados é perdida na FO e pode não ser evidente ao leitor digital. Também não há a presença dos elementos de dimensão verbo-visual que encontramos na FSP. Os enunciados não são acompanhados por qualquer fotografia, legendas ou mapas, conforme podemos observar nas figuras (18) a (20): 
Figura (18) Folha Online, 25 de novembro de 2003 - Reportagem (1) ${ }^{63}$

\section{$25 / 11 / 2003-06 h 38$}

\section{Satélite revela hora de irrigar plantações}

\section{SALVADOR NOGUEIRA da Folha de S.Paulo}

Num futuro não muito distante, imagens de satélite vão fornecer a estudiosos do cerrado e do semi-árido e a plantadores de milho e soja informações preciosas, como uma previsão do rendimento da safra e a hora mais adequada para irrigar os campos.

Antes que os dados enviados do espaço sejam transformados em algo útil à agricultura, no entanto, será preciso conduzir dois anos de pesquisa. O objetivo é justamente descobrir a fórmula matemática que "traduz" o que se vê no satélite na informação que realmente os plantadores querem saber: quanta umidade existe num dado território?

"É um algoritmo, que deve ser diferente dependendo do tipo de solo observado", explica Edson Sano, da Embrapa, instituição que está liderando os trabalhos no Brasil. A pesquisa envolve pesquisadores da Embrapa, do Inpe (Instituto Nacional de Pesquisas Espaciais) e de universidades, em parceria com a Nasa (agência espacial americana) e o USDA (Departamento de Agricultura dos Estados Unidos).

Do próximo domingo até 9 de dezembro, um avião da Nasa será usado para coletar imagens da região de Barreiras (no oeste baiano), uma área de transição entre o cerrado e o semi-árido. A esses dados serão reunidos os obtidos pelo satélite Aqua, projeto internacional liderado pela Nasa para estudar o ciclo hidrológico do planeta. Ambos os resultados serão comparados aos de coletas de amostras no local.

Com isso, será possível estabelecer uma correlação precisa entre o que se vê de cima e o que existe embaixo. Ao estabelecer o algoritmo (conjunto de instruções para processamento de dados) que ajuda a converter as leituras brutas do satélite em informações sobre umidade do solo, será possivel dispensar análises futuras com base em amostras, que tornam as avaliações mais lentas e caras.

"O uso só das imagens de satélite torna tudo muito mais dinâmico", diz Sano. "Não será preciso passar toda vez pelo processo de análise de amostras."

\section{Origem americana}

O projeto originalmente foi concebido nos Estados Unidos, onde está sendo executado desde 2002. "Nisso nós não tivemos participação nenhuma, foi inteiramente feito lá", afirma Sano.

Entretanto, com o sucesso do modelo, os pesquisadores brasileiros decidiram propor a implementação de um estudo similar em território nacional. Nada mais justo, uma vez que - Aqua possui um instrumento brasileiro a bordo e tem suas imagens recebidas também pelas instalações do Inpe em Cachoeira Paulista.

O Brasil será o primeiro país a se beneficiar dessa missão estendida do projeto americano. Em 2004, será a vez do México. O enfoque brasileiro será nas áreas semi-áridas e de cerrado. Não é possivel executar o estudo em região de floresta tropical, uma vez que as árvores da mata impedem a observação do solo pelo satélite.

"Temos quatro cenários para investigar", afirma Sano. "Cerrado, semi-árido e plantações de milho e soja." Nos dois primeiros casos, a aplicação é ambiental --entender melhor como a água flui (ou não flui) em regióes desse tipo. Mas, nos dois últimos, o uso vai além dos estudos acadêmicos.

Para o pesquisador da Embrapa, existem três aplicações. "A primeira é identificar os momentos mais adequados para a irrigação, com base na umidade do solo. A segunda é oferecer previsões das safras. E a terceira é acompanhar o rendimento da produção, que é muito importante para o [programa" Fome Zero."

O estudo em campo deve acontecer até o final de dezembro. Depois disso, a pesquisa entrará na fase de processamento dos dados colhidos, o que deve durar aproximadamente dois anos.

Especial

- Leia mais notícias e fique por dentro do Ambiente

\footnotetext{
${ }^{63}$ Disponível em: http://www1.folha.uol.com.br/folha/ciencia/ult306u10625.shtml. Acesso em: 19/05/2009.
} 
Figura (19) Folha Online, 25 de novembro de 2003 - Reportagem (2) ${ }^{64}$

\title{
25/11/2003 - 07h17 \\ Aeronáutica afirma que relatório final sobre 0 acidente será aberto
}

\author{
da Folha de S.Paulo
}

\begin{abstract}
A Aeronáutica voltou a se manifestar ontem sobre 0 encaminhamento das investigações sobre 0 acidente com 0 VLS-1 (Veículo Lançador de Satélites), afirmando que 0 relatório final deve ser divulgado publicamente.

"Estamos tentando fazer a coisa do modo mais transparente possível", disse o major Gustavo Krüger, do Cecomsaer, 0 Centro de Comunicação Social da Aeronáutica. Na última sextafeira, ele havia dito à Folha que a decisão sobre a divulgação do relatório ainda estava por ser tomada.
\end{abstract}

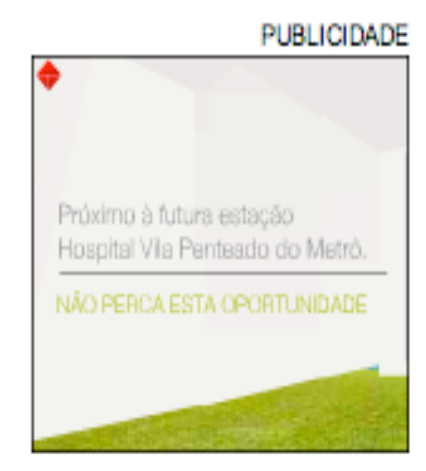

Krüger diz agora que houve um mal-entendido e que a única dúvida da Aeronáutica era sobre como exatamente seria feita a divulgação --o que, segundo ele, permanece. "Não sabemos ainda se haverá uma [entrevista" coletiva, se [o relatório" será colocado na internet, mas certamente tudo será amplamente divulgado", diz.

No sábado passado, 0 acidente que matou 21 pessoas no Centro de Lançamento de Alcântara, no Maranhão, completou três meses. A tragédia foi ocasionada pelo disparo de um dos propulsores do primeiro estágio, enquanto o foguete ainda estava sendo preparado para uma tentativa de lançamento. A causa da ignição do motor ainda não foi anunciada.

Logo após o acidente, uma comissão foi estabelecida pela Aeronáutica para investigar o caso, com prazo inicial de 30 dias. Foram feitos três pedidos de prorrogação nos meses subsequentes. Agora, o grupo liderado pelo brigadeiro-do-ar Marco Antonio Couto do Nascimento está chegando à fase final dos trabalhos, que devem ser concluídos até o dia 15 de dezembro.
Leia mais
- Investigacăo do VLS-1 deve ser prorrogada
- Aprovada indenizaçáo para famil as das vitimas de Alcantara
- CTA define pensóes para as familias das vitimas
- Comissáa aponta descarga elétrica cono causa do acidente
Especial
- Veja galeria com fotos do desastre no centro de lançamento

\footnotetext{
${ }^{64}$ Disponível em: http://www1.folha.uol.com.br/folha/ciencia/ult306u10626.shtml. Acesso em: 19/05/2009.
} 
Figura (20) Folha Online, 25 de novembro de 2003 - Reportagem (3) 65

\title{
25/11/2003-08h02 \\ Brasil e Argentina pedem juntos US\$ $70 \mathrm{mi}$ ao BID para pesquisa
}

\author{
da Folha de S.Paulo, no Rio \\ O ministro da Ciência e Tecnologia, Roberto Amaral, anunciou \\ ontem no Rio que o Brasil e a Argentina fizeram um pedido \\ conjunto de empréstimo ao BID (Banco Interamericano de \\ Desenvolvimento) no valor de US\$70 milhões. Cada país daria \\ também US\$15 milhões, totalizando US\$100 milhões para \\ serem investidos em ciência e tecnologia. \\ De acordo com Amaral, o pedido foi feito em junho deste ano \\ para o presidente do BID, Enrique Iglesias, que teria se \\ mostrado interessado no projeto.
}



\begin{abstract}
Na proposta apresentada por Brasil e Argentina, os recursos seriam divididos igualmente entre os países, que teriam liberdade para decidir onde investi-los dentro de uma pauta comum.
\end{abstract}

\begin{abstract}
Ao discursar no seminário "Mercosul: Ciência, Tecnologia e Inovação", na sede do BNDES, Amaral afirmou que entre as áreas de interesse comum entre Brasil e Argentina estão a genômica, a proteômica e a de competitividade agroindustrial.

O ministro afirmou também que o Brasil poderá liberar para os países do Mercosul, "sem interesse comercial", informações obtidas pelo satélite Cbers-2 (lançado em parceria com a China).
\end{abstract}

\begin{abstract}
Ele voltou a defender que uma parcela dos juros a serem pagos a título de rolamento da dívida externa seja revertida em investimentos em educação, ciência, pesquisa e inovação.

"Parto do pressuposto de que os credores são inteligentes e precisam manter a galinha dos ovos de ouro funcionando", disse o ministro, fazendo uma referência ao fato de o Brasil ser um dos países que mais paga juros de dívida.
\end{abstract}

$\mathrm{Na}$ FSP, se pensarmos a primeira reportagem como o enunciado-fonte, a partir do qual se articulam as relações dialógicas hipertextuais, podemos estabelecer um eixo de ordem temática pela qual a remissão é feita: todas as reportagens tratam de assuntos relacionados à esfera científica em território brasileiro. Diferentemente da primeira análise, em que a dimensão verbo-visual articulava a relação entre todos os demais enunciados, os nós remissivos na seleção de 2003 não são evidentes. A composição da primeira reportagem

\footnotetext{
${ }^{65}$ Disponível em: http://www1.folha.uol.com.br/folha/ciencia/ult306u10627.shtml. Acesso em: 19/05/2009.
} 
possui um título de tamanho dominantemente maior envolvendo inclusive espacialmente a segunda reportagem, como uma espécie de indexação.

Quando fazemos a comparação com a FO, percebemos que também há uma indexação linear ao final da página, na medida em que outras reportagens afins - não necessariamente as mesmas da FSP - são elencadas nos itens "Leia Mais" e "Especial", o que sugere um maior aprofundamento sobre o assunto por parte do leitor. Os nós remissivos eletrônicos continuam a ser o mecanismo produtivo articulador de tais relações na rede.

No tocante aos planos de remissão, a FSP apresenta uma mudança de perfil, pois possui mais elementos de dimensão verbal e verbo-visual em confluência dentro do mesmo enunciado. As duas primeiras reportagens possuem imagens - um mapa representado na primeira e um registro fotográfico feito via satélite na segunda - e há a inserção de uma fotolegenda na seção 'Panorâmica'. Retomando o quadro de planos remissivos adotada na primeira análise, observamos que a FSP preserva o plano interno primário (correspondente às relações dialógicas hipertextuais entre os elementos verbais e verbo-visuais de um mesmo enunciado); o plano externo primário na relação temática entre as 3 reportagens da mesma página; e o plano externo secundário, a partir da relação dos conteúdos da página com o editorial destacado anteriormente na seção. Entretanto, a ocorrência deste último não foi tão contundente como observado na primeira análise.

Já na FO, as remissões de caráter externo são praticamente constitutivas da concretização dos enunciados digitais. Os planos externos são mais produtivos, mesmo porque a forma lógica continua a ser importada dos autores da publicação impressa, e seria muito trabalhoso inserir qualquer tipo de nó remissivo interno ao enunciado digital.

Nesse momento, fazemos uma reflexão que poderá ou não se confirmar mais adiante. A falta de uso interno de nós eletrônicos na FO é uma evidência da não autonomia da editoria de ciência no jornal digital. Cremos que a partir do momento em que enunciados forem elaborados para serem publicados em meio digital, o aproveitamento do mecanismo eletrônico de remissão será mais bem aproveitado, sobretudo em reportagens. O nó admite a indexação e a organização de pontos de vista externos que contribuem para a configuração temática daquele enunciado. Se ainda não houve tal aproveitamento no âmbito digital, isso significa que a DC ainda não está consolidada e não é autônoma o suficiente na FO em 2003. Ao mesmo tempo, a FSP parece começar a incorporar a autonomia no que tange à complexidade da cada enunciado, tendo as fronteiras mais demarcadas e a dimensão verbovisual mais fragmentada, ou seja, na medida e que cada enunciado é desdobrado em sua dimensão verbal e verbo-visual. 


\subsubsection{A política científica e as duas faces da corrida espacial brasileira}

As reportagens dispostas na FSP são um reflexo do que apontamos anteriormente sobre o eixo da corrida espacial brasileira inserida em um momento de grande ascensão da revanche americana na luta contra o terrorismo. A relação dialógica entre os enunciados da página denuncia a subordinação do país a práticas tecnológicas dos EUA, bem com ao capital do BID (Banco Interamericano de Desenvolvimento) para investimentos e melhorias das pesquisas no país. O contraponto com a grande potência da época é reforçado pelo aparecimento de um terceiro país na segunda reportagem, a Argentina que, assim como o Brasil, é um país que à época necessitava de recursos e de ajuda financeira externa.

Tanto EUA, quanto Brasil e Argentina são membros do BID, mas possuem status diferentes. Enquanto os EUA participam da classe de países membros não-mutuários, Brasil e Argentina fazem parte da classe dos mutuários do grupo I, ou seja, daqueles que recebem os empréstimos dos países não-mutuários. De acordo com as informações colhidas no site do BID, os EUA seriam um dos provedores aos países em desenvolvimento ou com renda per capita mais baixa, o que condiz com o papel que o país assume na reportagem sobre o satélite. A partir do subtítulo "Origem americana", a segunda parte do primeiro enunciado narra a concepção do projeto do satélite criado para controlar a irrigação de plantações nos EUA, onde estava sendo executado há mais de um ano. No entanto, a fala do cientista brasileiro opõe-se à soberania americana no estudo ao apontar que o Brasil havia confeccionado uma peça para o satélite e que, então, era justo que o Brasil implementasse a melhoria no país. O jornalista também reforça a dupla natureza do estudo, tanto no título quanto no elemento verbo-visual que acompanha o enunciado verbal.

Torna-se interessante observar que a tentativa de colocar o Brasil no mesmo patamar de pesquisa e avanços tecnológicos de um país como os EUA, venha acompanhado de outras duas reportagens que, respectivamente, abordam o fracasso no lançamento do satélite da base de Alcântara e o desenrolar cuja transparência seria questionada ao longo dos meses que se seguiram, bem como do pedido de fomento ao BID. A reportagem sobre o BID revela ainda uma tentativa do país em apresentar alguma soberania sobre países menos desenvolvidos, sobretudo no seguinte trecho: “O ministro afirmou também que o Brasil poderá liberar para os países do Mercosul, 'sem interesse comercial', informações obtidas pelo satélite Cbers-2 (lançado em parceria com a China)".

O conteúdo temático da página é constituído por contradições num percurso que segue a seguinte ordem: primeiramente, o reconhecimento da supremacia americana na área 
científica, por conta do pioneirismo de aplicação da tecnologia via satélite; segundo, a mudança de patamar do país como um igual no que tange a essa aplicabilidade, uma vez que o Brasil participou do processo de construção do satélite; terceiro, o desastre de uma investida científico-tecnológica brasileira; e o pedido por investimentos que distancia o Brasil do patamar assumido na primeira reportagem, já que se torna credor e não mais parceiro dos EUA, mas que procura manter seu posicionamento de superioridade em relação aos demais países.

Tal movimento denota a complexa relação entre as esferas científica e política e suas práticas destoantes no Brasil. As reportagens mostram que enquanto a competência puramente científica alavanca o Brasil a patamares altíssimos, o governo tenta esquivar-se das polêmicas em torno do acidente, chamando a atenção para a entrada de novos investimentos no país. No entanto, há a quebra do patamar de parceiro a subordinado que o ministro tenta deslocar para o fato de que o Brasil também pode possuir países subordinados tanto sob o ponto de vista financeiro, quanto do ponto de vista científico.

\subsubsection{A apropriação da esfera científica na dimensão verbo-visual}

Conforme já observamos, os elementos da dimensão verbo-visual não são aproveitados pela FO. Contrariando nossas expectativas iniciais, a tecnologia digital ainda não participa da constituição dos enunciados que analisamos até 2003. Entretanto, dissemos anteriormente que tal fato ocorre, pois os enunciados do nosso corpus emergem da esfera de produção impressa e a transposição da forma lógica de um meio a outro não só inibe a incorporação de características do meio digital, mas faz com que o enunciado sofra a perda de elementos que o constituíam no meio impresso.

A dimensão verbo-visual da FO continuou a ser constituída por fatores de ordem peritextuais, enquanto que a FSP apresentou uma mudança significativa em sua página. A partir dos conteúdos temáticos identificados na seção anterior, podemos considerar que a editoria de ciência da FSP ainda é um espaço bem marcado para a discussão de fatos políticos. No entanto, em 2003 houve uma modificação temática em relação ao primeiro ano analisado, no sentido de que as questões políticas estão cada vez mais interiorizadas na esfera científica. Se antes o espaço da DC no jornal era dedicado a questões da esfera política e sua interface com questões científicas, o eixo temático agora gira em torno das questões científicas que possuem alguma relação de ordem política. Há uma grande diferença entre 
essas duas orientações cuja tendência é influenciada pelo fortalecimento da cultura científica no país.

Tal fato pode ser confirmado ao analisarmos a dimensão verbo-visual da página da FSP reproduzida na figura (8). Os elementos visuais da primeira reportagem possuem uma relação dialógica hipertextual de plano primário interno com seu enunciado. O mapa, cuja inserção pode ser considerada hipertextual no enunciado-fonte, visa atribuir uma nova informação ao enunciado, denunciando o local do acontecimento. Nesse caso, vemos uma sobreposição do mapa do Brasil sobre o mapa da Bahia, o que revela uma nova relação hipertextual no interior da imagem. O mapa do Brasil é redimensionado pelo mapa maior que localiza a cidade de Barreiras no interior do estado da Bahia. Apesar de pequeno, a inserção do mapa pelo "box" explicativo é um elemento complexo para a composição do enunciado. 


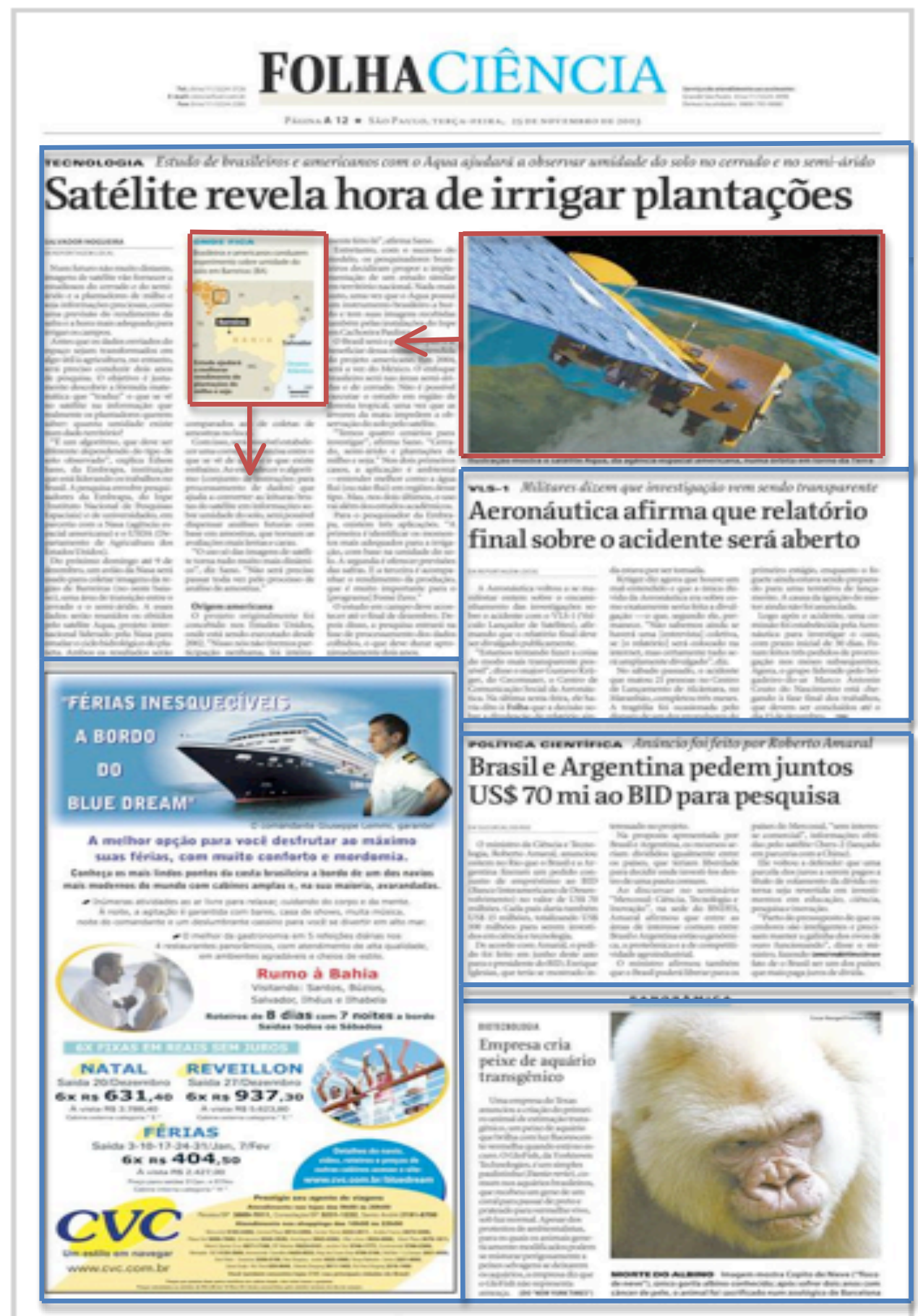

A fotografia do satélite que complementa o enunciado é uma evidência de que os enunciados passam a incorporar características mais pertinentes à esfera científica que política, fato reforçado pela própria fonte da imagem indicada na parte superior esquerda 'divulgação NASA' - e descrita na legenda: Ilustração mostra o satélite Acqua, da agência espacial americana, numa órbita em torno da Terra. 
Um outro exemplo da legitimação da esfera científica é a divulgação da foto do Gorila albino, cuja legenda é autônoma. As fotolegendas que observamos ao longo do corpus precedem a inserção dos infográficos no discurso de DC da FSP. O caráter autoexplicativo da pequena reportagem cuja dimensão é verbo-visual em sua totalidade pode ser considera um gênero distinto? Estendemos a mesma questão aos os infográficos no capítulo 5. Consideramos que não, uma vez que a delimitação estilístico-composicional está condicionada à seção panorama, um pequeno mosaico de reportagens ou notícias curtas bem demarcado na página.

$\mathrm{Na} \mathrm{FO}$, a dimensão verbo-visual assume uma nova forma concretizada por meio dos nós eletrônicos. Somente duas das três reportagens possuem nós remissivos que relacionam o enunciado a outras reportagens ou seções do portal. Em Satélite revela a hora de irrigar plantações, há uma relação dialógica hipertextual a um enunciado de plano externo ligada ao enunciado por meio de um nó remissivo disposto ao final da reportagem:

Figura (22) - Reprodução de fragmento da reportagem Satélite revela a hora de irrigar plantações

(...)

O estudo em campo deve acontecer até o final de dezembro. Depois disso, a pesquisa entrará

na fase de processamento dos dados colhidos, o que deve durar aproximadamente dois anos.

Especial

- Leia mais notícias e fique por dentro do Ambiente

No exemplo acima, a relação dialógica é de complementação por meio da introdução de novos dados. O leitor é levado ao índice da editoria "Ambiente" podendo acessar outros enunciados que não necessariamente pertencem ao mesmo eixo temático do enunciado-fonte.

Já na reportagem Aeronáutica afirma que relatório final sobre acidente será aberto, observamos que a indexação de enunciados ao final do enunciado-fonte é mais complexa e apresenta uma especificidade, a inserção de uma galeria de imagens sobre o acidente. Observamos que ambos os nós aos enunciados sobre evento publicados em dias anteriores e a presença da galeria de imagens promovem um tipo de relação dialógica que pode ser considerado de complementação, mas possuem um objetivo específico: a identificação do tempo-espaço e do contexto histórico do enunciado-fonte. Tal complementação visa atribuir informações sobre o espaço e a cronologia do acontecimento, como se as reportagens elencadas pelos nós eletrônicos funcionassem como uma espécie de linha do tempo. 
Figura (23) - Reprodução de fragmento da reportagem Aeronáutica afirma que relatório final sobre acidente será aberto

Logo após o acidente, uma comissão foi estabelecida pela Aeronáutica para investigar o caso, com prazo inicial de 30 dias. Foram feitos três pedidos de prorrogação nos meses subsequentes. Agora, o grupo liderado pelo brigadeiro-do-ar Marco Antonio Couto do Nascimento está chegando à fase final dos trabalhos, que devem ser concluídos até o dia 15 de dezembro.

Leia mais

- Investigaçä́o do VLS-1 deve ser prorrogada

- Aprovada indenização para familias das vítimas de Alcântara

- CTA define pensões para as familias das vítimas

- Comissão aponta descarga elétrica como causa do acidente

Especial

- Veja galeria com fotos do desastre no centro de lançamento

(...)

Figura (24) - Reprodução de galeria de imagens da reportagem Aeronáutica afirma que relatório final sobre acidente será aberto
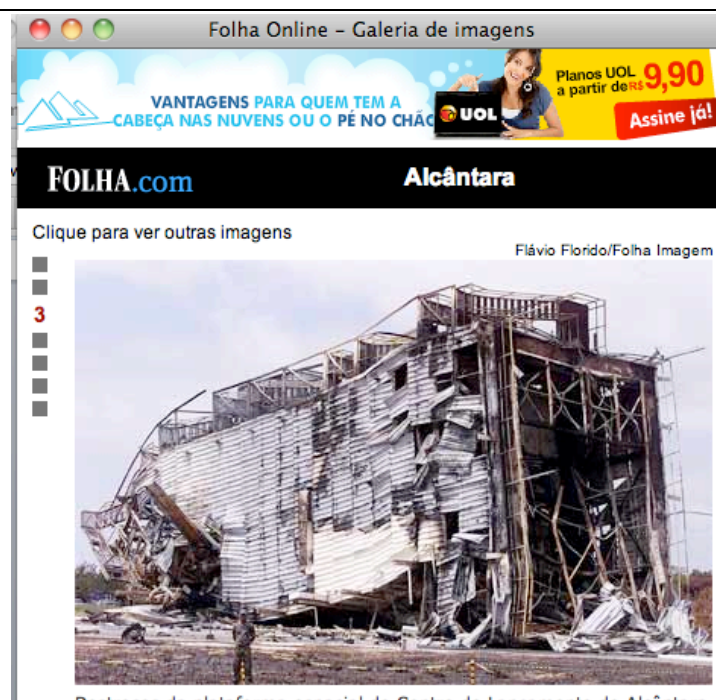

Destroços da plataforma espacial do Centro de Lançamento de Alcântara após o acidente que deixou 21 mortos na sexta-feira (22)

Na FSP as relações dialógicas hipertextuais encontradas são de outra ordem. As três reportagens possuem caráter autônomo no que tange a sua tematicidade, mas possuem como aspecto central questões político-econômicas da esfera científica brasileira. Na reportagem principal Satélite revela a hora de irrigar plantações, os dois elementos verbo-visuais estabelecem relação dialógica de plano interno primário com o enunciado. O mapa disposto no box explicativo de menor tamanho inserido no centro da dimensão verbal estabelece uma 
relação dialógica hipertextual de complementaridade para definição do tempo-espaço, assim como já observado em outro exemplo acima. Enquanto isso, a projeção artística da imagem do satélite, que aliás compõe a dimensão verbo-visual em conjunção com o título da reportagem, trava uma relação dialógica hipertextual para o reconhecimento da esfera científica, a partir da fonte do dado utilizado - trata-se de uma foto da agência espacial americana Nasa, como descrevemos anteriormente.

As outras duas reportagens estabelecem uma relação dialógica hipertextual de concordância em conjunto com o enunciado-fonte e o editorial do jornal. Entretanto, a relação de concordância que resvala na crítica das políticas públicas da esfera científica é feita por meio de uma polêmica velada, não sendo evidente ao leitor no plano verbal ou verbo-visual.

\subsubsection{Síntese}

Em 2003, destacamos que a unidade temática das reportagens apresentadas é o eixo pelo qual se desenrola a hipertextualidade na FSP, no entanto, o tipo de relação é feito sob forma de uma indexação linear, assim como na FO. A diferença no aproveitamento de elementos verbo-visuais no jornal digital, em comparação com o impresso, aponta que os enunciados são formulados para ocuparem a página impressa e sua forma lógica, sendo transpostas ao jornal digital, nem congregam as características do meio impresso e muito menos inserem elementos típicos da tecnologia digital, como o nó eletrônico.

As reportagens impressas estão em relação dialógica constituindo uma unidade temática, cuja apreensão revela a tentativa de reposicionar o Brasil ao mesmo tempo como um país produtor de conhecimento, na busca em se estabelecer uma comparação com os EUA, e provedor, no caso de sua relação com a Argentina. Se recuperarmos o estudo dos Indicadores de C,T\&I feitos pela FAPESP (FAPESP, 2004), temos a informação de que, até aquele momento, o Brasil era maior exportador de conhecimento do que referência no setor econômico mundial.

A FO parece ter a sua editoria direcionada para uma maior autonomia no que tange à indexação de enunciados ao enunciado-fonte. No caso, todos os enunciados indexados pelo nó eletrônico visam ao acréscimo de informações, detalhamento ou expansão do assunto ou fato tratado na reportagem. Ao passo em que as reportagens da FPS parecem pertencer a um mesmo eixo temático, a FO descentraliza as reportagens, direcionando-as para outras reportagens e criando relações dialógicas hipertextuais diferentes. 


\subsection{Um reflexo sobre o interesse da sociedade acerca do meio ambiente e da corrida espacial: análise de reportagens do ano 2005}

No que tange ao contexto sócio-histórico, o mês de novembro de 2005 foi marcado por uma série de eventos científicos no âmbito da exploração espacial e do aquecimento global. Vimos que as reportagens que configuram a página do jornal referente a esta data participam de ambos os domínios da esfera científica e que tiveram motivação a partir de dois eventos específicos. As reportagens sobre o clima circularam em maior proporção na FO e tiveram um destaque menor na FSP. Já o jornal impresso selecionou mais reportagens vinculadas à exploração espacial do que aquelas que tratavam sobre questões climáticas.

As questões relativas ao meio ambiente, além de serem assunto recorrente e de interesse do leitor presumido da FSP, devem-se, especificamente, à Conferência Mundial sobre o Clima que ocorria no Canadá. Nesse mesmo mês, Marcos Pontes preparava-se para ser o primeiro brasileiro a seguir em missão espacial que seria realizada em 30 de março de 2006. Ao longo do mês de novembro, foram publicadas inúmeras reportagens a respeito da corrida espacial, fazendo com que os programas de lançamento de satélites e missões de diversos países fossem demasiadamente explorados.

A maior atenção ao assunto pela FSP deve-se, primeiramente, ao espaço físico do jornal impresso para a veiculação de informações. Com isso, acreditamos que o destaque dado aos estudos e avanços cosmológicos esteja relacionado ao fato de, naquele momento, tal domínio estar mais próximo à realidade da sociedade brasileira sob o ponto de vista social. O impacto de uma conferência climática não seria tão imediato quanto à possibilidade de enviarmos o primeiro astronauta brasileiro a uma missão no espaço e a questão da identificação nacional obteve maior atenção.

No tocante à autoria, Cláudio Ângelo assina a reportagem sobre o clima e Salvador Nogueira é responsável pela cobertura da corrida espacial. O primeiro, que em 2000 era um colaborador da seção Folha Ciência, agora é seu próprio editor. Nogueira, também jornalista especializado em jornalismo científico, possui afinidade com assuntos da área cosmológica, fato demonstrado por seu vínculo à Associação Aeroespacial Brasileira como conselheiro, bem como pela publicação de livros na área (Rumo ao infinito: passado e futuro da aventura humana na conquista do espaço. São Paulo: Editora Globo, 2005) e pela edição de um site chamado Trek Brasilis que trata da série ficcional Star Trek.

A caracterização do leitor presumido é dada por meio da análise dos anúncios publicitários. Observamos que a página é composta por duas peças publicitárias que dividem 
o espaço com mais duas reportagens. Os anúncios publicitários, mais uma vez, não possuem relação direta com os demais enunciados, mas evidenciam traços do possível leitor presumido da FSP. Na primeira peça, revela-se um leitor presumido com bom poder aquisitivo e que pode realizar as viagens propostas pela CVC. No caso do segundo anúncio publicitário, vemos o aparecimento de um grupo específico dentre o público presumido da FSP, o de assinantes do jornal. Trata-se de um anúncio que prevê a fidelização dos assinantes por meio de uma promoção para a aquisição de um produto.

Novamente, verificamos o aparecimento do hipertexto e da presença de um nó remissivo eletrônico em "acesse www.folha.com.br/harrypotter e peça sua coleção". Há hipertextualidade prevista na articulação por meio do nó remissivo que trava uma relação entre enunciados dos dois jornais. Percebemos que a estratégia da peça não é somente fidelizar, ou mesmo atrair novos assinantes para o jornal impresso, mas também é de interesse do jornal impresso que os leitores conheçam a sua publicação digital.

\subsubsection{Confluências entre os enunciados impresso e digital}

Para o fechamento da análise do primeiro segmento do corpus, fizemos uma caracterização dos enunciados das reportagens de 2005 no tocante aos aspectos estilísticocomposicionais a partir dos quais são concretizados. Abaixo, apresentamos a reprodução das reportagens da FSP que compõem o corpus do ano de 2005 e, em seguida, uma tabela (2) descritiva sobre a organização hiperestrutural da página do jornal impresso: 


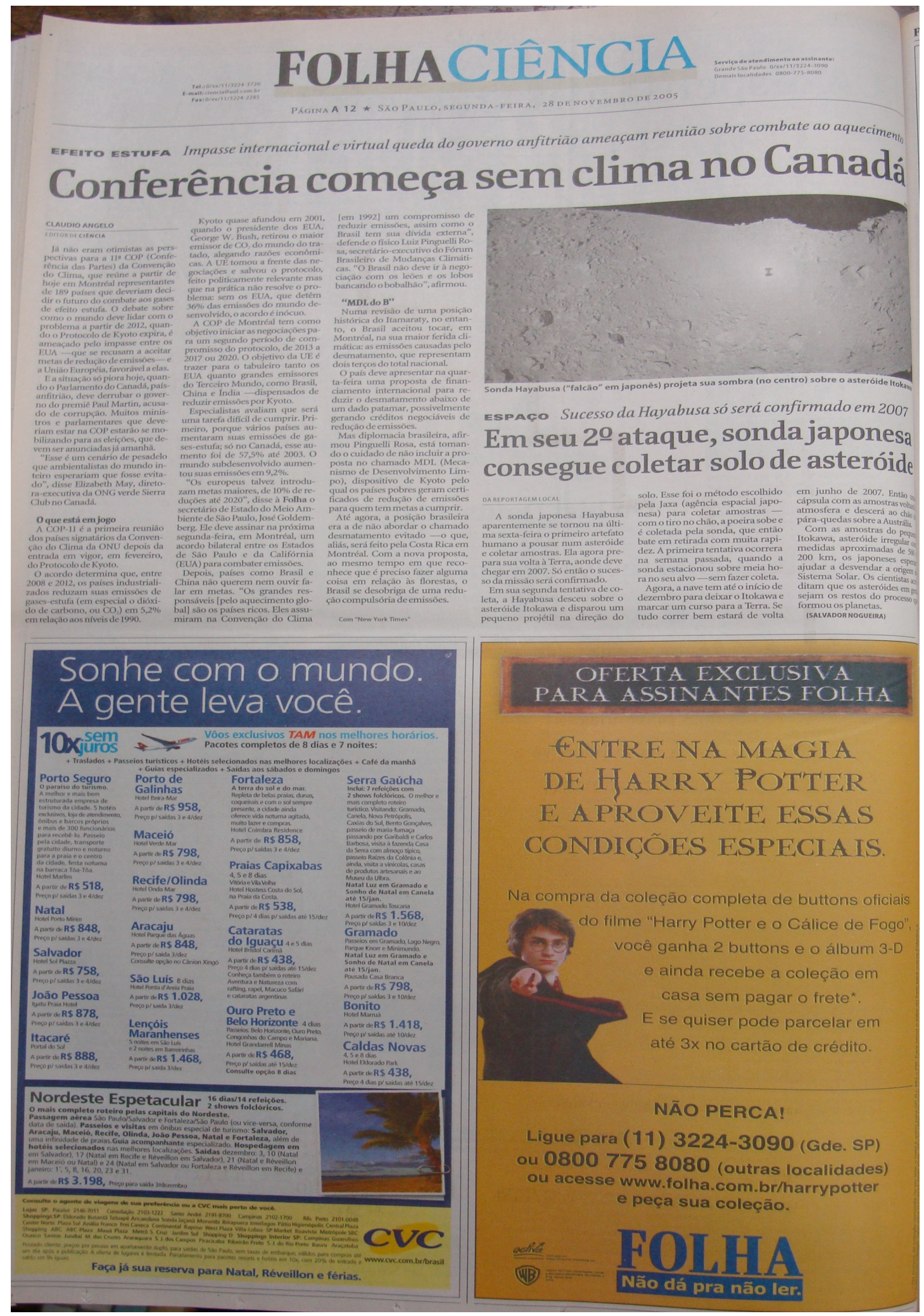


Tabela (9) Hiperestrutura da Folha de S. Paulo, 28 de novembro de 2005

\begin{tabular}{|c|c|c|}
\hline \multicolumn{3}{|r|}{ REPORTAGEM 1} \\
\hline \multirow{4}{*}{$\begin{array}{c}\text { ENUNCIADO } \\
1\end{array}$} & $\begin{array}{l}\text { Chapéu e } \\
\text { título auxiliar }\end{array}$ & $\begin{array}{l}\text { Efeito Estufa: Impasse internacional e virtual do governo anfitrião ameaçam } \\
\text { reunião sobre combate ao aquecimento }\end{array}$ \\
\hline & Título & Conferência começa sem clima no Canadá \\
\hline & Subtítulo 1 & O que está em jogo \\
\hline & Subtítulo 2 & "MDI do B" \\
\hline \multicolumn{3}{|r|}{ REPORTAGEM 2} \\
\hline \multirow{2}{*}{$\begin{array}{l}\text { ENUNCIADO } \\
1\end{array}$} & $\begin{array}{l}\text { Chapéu e } \\
\text { título auxiliar }\end{array}$ & Espaço: Sucesso da Hayabusa só será confirmado em 2007 \\
\hline & Título & Em seu $2^{\circ}$ ataque, sonda japonesa consegue coletar solo de asteroide \\
\hline $\begin{array}{l}\text { ELEMENTO } \\
\text { VERBO- } \\
\text { VISUAL }\end{array}$ & \multicolumn{2}{|c|}{$\begin{array}{l}\text { Foto tirada pela sonda com a legenda "Sonda Hayabusa ("falcão" em japonês) projeta essa } \\
\text { sombra (no centro) sobre o asteróide }\end{array}$} \\
\hline \multicolumn{3}{|r|}{ ENUNCIADOS DE PUBLICIDADE } \\
\hline \multirow{2}{*}{ PEÇA 1} & Produto & Pacotes de viagem da empresa CVC \\
\hline & $\begin{array}{l}\text { Chamada } \\
\text { principal }\end{array}$ & Sonhe com o mundo. A gente leva você. \\
\hline \multirow{2}{*}{ PEÇA 2} & Produto & Coleção de produtos voltados para assinantes da Folha de S. Paulo \\
\hline & $\begin{array}{l}\text { Chamada } \\
\text { principal }\end{array}$ & Entre na magia de Harry Potter e aproveite essas condições especiais \\
\hline
\end{tabular}

Se comparada às anteriores, a hiperestrutura em 2005 parece não ser tão complexa. A organização hiperestrutural da página da reportagem de 2005 ainda preserva as características encontradas em 2000, ou seja, as reportagens são visivelmente delimitadas pela presença de um chapéu e título auxiliar demarcadores da área da ciência a que se referem e uma das ideias principais que serão desenvolvidas no enunciado. Por meio de tais elementos, notamos que as duas reportagens não estabelecem qualquer relação aparente entre si. No entanto, por meio da verificação da ocorrência de todas as reportagens que foram publicadas no mês de novembro daquele ano, sabemos que o fato de esse recurso ser 
utilizado para dividir a página do jornal não é aleatório. Conforme argumentamos anteriormente, trata-se de assuntos de interesse do leitor presumido, os quais tiveram repercussão não somente em nível nacional, como também mundial, e que podem interessar a toda sociedade brasileira.

Ambas as reportagens publicadas possuem apenas um enunciado cada, não havendo a participação de outros enunciados fragmentados. A primeira reportagem relaciona a tensão entre os países integrantes da conferência com o intuito de resolver a incompatibilidade de interesses entre eles e a crise política pela qual passava o país sede do encontro, o Canadá, que teria o seu primeiro ministro deposto por conta de acusações de corrupção. O título da reportagem (1) refere-se a tal tensão em ambos os acontecimentos por meio do emprego da expressão "sem clima" que também é uma metáfora à problematização da questão principal visada pela conferência, as mudanças climáticas. A partir da expressão "sem clima" estabelece-se, então, um discurso bivocal. Ao mesmo tempo em que a palavra bivocal em questão volta-se para o objeto do seu discurso - o desconforto político entre os países - e para o objeto do discurso ambientalista que promulga a diminuição dos poluentes para a preservação climática do planeta.

A reportagem é subdividida em três partes, separadas por subtítulos. A primeira trata de situar o leitor a respeito da conferência. Apesar de o clima ser um assunto constantemente mobilizado pelo jornal, é a primeira vez que se fala da conferência. Ao contrário do encontro em Haia, que obteve ampla divulgação prévia, o mesmo não ocorreu com o evento na Canadá. Este fato pode estar refletido na falta de sucesso das edições anteriores do evento e na repercussão negativa no tocante ao acordo entre os países. Enquanto isso, a segunda parte da reportagem traz "o que está em jogo" no panorama internacional e o acarretamento das ações dos países para o clima do mundo. A terceira e última parte, denominada "MDL do B" é destinada ao papel e estratégias do Brasil. Geralmente, o lado B refere-se ao oposto, podendo significar o outro lado da situação, ao mesmo tempo que se refere ao país.

A segunda reportagem traz um acontecimento de valoração entonativa positiva sobre a corrida espacial, o que dialoga com o momento do Brasil na área em questão. Se no âmbito climático as notícias não são animadoras para o país, a possibilidade de termos um astronauta brasileiro em missão no espaço está refletida e refratada no interesse da imprensa na concretização de enunciados que tratam do assunto, bem como no interesse do leitor presumido.

$\mathrm{Na} \mathrm{FO}$, a reportagem possui as mesmas características composicionais no que tange à subdivisão do texto, como a apresentação da assinatura do autor logo abaixo do título, no 
entanto, sem a presença do chapéu. Acrescenta-se o emprego de nós remissivos por meio de hiperlink ao final da reportagem que a remetem a outra reportagem específica relacionada à mesma questão, bem como a uma compilação de tudo o que fora publicado a respeito do aquecimento global na FO anteriormente.

Figura (26) Folha Online, 28 de novembro de 2005 - Reportagem (1) 66

\section{ciência}

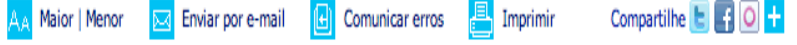

\section{8/11/2005 - 09h20}

\section{Conferência começa sem clima no Canadá}

\section{CLAUDIO ANGELO}

da Folha de S.Paulo

Já não eram otimistas as perspectivas para a $11^{\mathrm{a}} \mathrm{COP}$ (Conferência das Partes) da Convenção do Clima, que reúne a partir de hoje em Montréal representantes de 189 paises que deveriam decidir o futuro do combate aos gases de efeito estufa. 0 debate sobre como o mundo deve lidar com o problema a partir de 2012, quando o Protocolo de Kyoto expira, é ameaçado pelo impasse entre os EUA --que se recusam a aceitar metas de redução de emissões-- e a União Européia, favorável a elas.

E a situação só piora hoje, quando o Parlamento do Canadá, pais-anfitrião, deve derrubar o governo do premiê Paul Martin, acusado de corrupção. Muitos ministros e parlamentares que deveriam estar na COP estarão se mobilizando para as eleições, que devem ser anunciadas já amanhã.

"Esse é um cenário de pesadelo que ambientalistas do mundo inteiro esperariam que fosse evitado", disse Elizabeth May, diretora-executiva da ONG verde Sierra Club no Canadá.

\section{0 que está em jogo}

A COP-11 é a primeira reunião dos países signatários da Convenção do Clima da ONU depois da entrada em vigor, em fevereiro, do Protocolo de Kyoto.

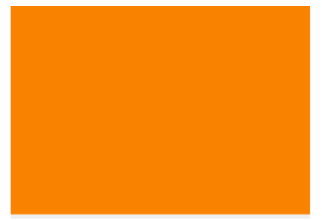

asúltimas que vocênãoleu

1. PMs confundem colega com assaltante e matam policial no Rio

2. Televisa e Lionsgate se unem para 0 público latino dos EUA

3. A R\$ 9,90, "Homem Chavão" alerta para clichês na hora da morte de famosos

4. Justiça argentina condena padre pedófilo a 15 anos de prisão

5. Em Altamira, Serra diz que sabe bater pênalti

6. Figueirense perde para o AméricaMG e corre risco de sair da ponta da Série B

7. Bombeiros controlam incêndio na zona sul de SP; favela da zona leste é atinginda

8. TSE nega direito de resposta de Dilma em programa de Serra por conta de luz

9. Museu de Berlim expõe cerca de 50 mil animais com até 240 anos: veía

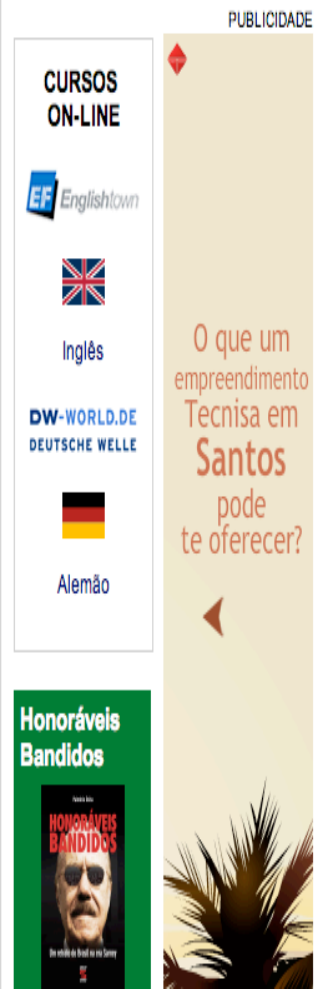

\footnotetext{
${ }^{66}$ Disponível em: http://www1.folha.uol.com.br/folha/ciencia/ult306u13999.shtml. Acesso em: 19/05/2009.
} 
0 acordo determina que, entre 2008 e 2012, os paises industrializados reduzam suas emissões de gases-estufa (em especial o dióxido de carbono, ou CO2) em 5,2\% em relação aos niveis de 1990.

Kyoto quase afundou em 2001, quando o presidente dos EUA, George W. Bush, retirou 0 maior emissor de $\mathrm{CO} 2$ do mundo do tratado, alegando razões econômicas. A UE tomou a frente das negociações e salvou o protocolo, feito politicamente relevante mas que na prática não resolve o problema: sem os EUA, que detêm $36 \%$ das emissões do mundo desenvolvido, 0 acordo é inócuo.

A COP de Montréal tem como objetivo iniciar as negociações para um segundo período de compromisso do protocolo, de 2013 a 2017 ou 2020. 0 objetivo da UE é trazer para 0 tabuleiro tanto os EUA quanto grandes emissores do Terceiro Mundo, como Brasil, China e India --dispensados de reduzir emissões por Kyoto.

Especialistas avaliam que será uma tarefa difícil de cumprir. Primeiro, porque vários paises aumentaram suas emissões de gases-estufa; só no Canadá, esse aumento foi de $57,5 \%$ até 2003. 0 mundo subdesenvolvido aumentou suas emissões em 9,2\%

"Os europeus talvez introduzam metas maiores, de 10\% de reduções até 2020", disse à Folha o secretário de Estado do Meio Ambiente de São Paulo, José Goldemberg. Ele deve assinar na próxima segunda-feira, em Montréal, um acordo bilateral entre os Estados de São Paulo e da Califórnia (EUA) para combater emissões.

Depois, paises como Brasil e China não querem nem ouvir falar em metas. "Os grandes responsáveis [pelo aquecimento global] são os países ricos. Eles assumiram na Convenção do Clima [em 1992] um compromisso de reduzir emissões, assim como o Brasil tem sua divida externa", defende o físico Luiz Pinguelli Rosa, secretário-executivo do Fórum Brasileiro de Mudanças Climáticas. "O Brasil não deve ir à negociação com os leões e os lobos bancando 0 bobalhão", afirmou.

\section{"MDL do B"}

Numa revisã̃o de uma posição histórica do Itamaraty, no entanto, o Brasil aceitou tocar, em Montréal, na sua maior ferida climática: as emissões causadas pelo desmatamento, que representam dois terços do total nacional.

0 pais deve apresentar na quarta-feira uma proposta de financiamento internacional para reduzir o desmatamento abaixo de um dado patamar, possivelmente gerando créditos negociáveis de redução de emissões.

Mas diplomacia brasileira, afirmou Pinguelli Rosa, está tomando o cuidado de não incluir a proposta no chamado MDL (Mecanismo de Desenvolvimento Limpo), dispositivo de Kyoto pelo qual os paises pobres geram certificados de redução de emissões para quem tem metas a cumprir.

Até agora, a posição brasileira era a de não abordar o chamado desmatamento evitado - 0 que, aliás, será feito pela Costa Rica em Montréal. Com a nova proposta, a mesmo tempo em que reconhece que é preciso fazer alguma coisa em relação às florestas, 0 Brasil se desobriga de uma redução compulsória de emissões.

Com "New York Times"

Leia mais

- Gás carbonico bate recorde de 650 mil anos

Especial

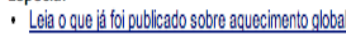

10. Cinema brasileiro é destaque em festival francês Biarritz

PUBLICIDADE

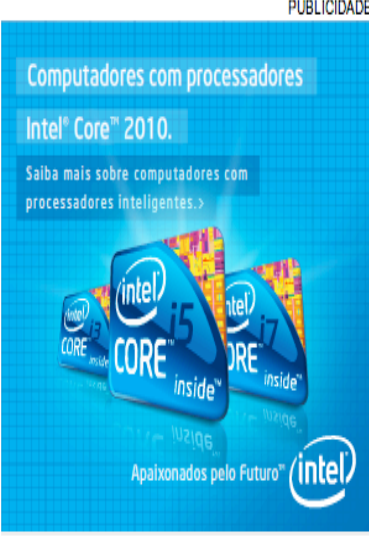

+lidas

1. Exame de sangue pode detectar Alzheimer, diz estudo

2. Concurso para professor universitário ignora pós multidisciplinar

3. Cientista alerta sobre superbactéria resistente a quase todos antibióticos

4. Felicidade custa R\$̣ 11 mil por mês, aponta estudo

5. Meteorito que caiu na França tem estilhaços de supernova

\section{+ comentadas}

1. Felicidade custa R\$̣ 11 mil por mês, aponta estudo

2. Foguete nacional só deve decolar em 2015

\section{+ enviadas}

1. Exame de sangue pode detectar Alzheimer, diz estudo

2. Felicidade custa R\$̣ 11 mil por mês, aponta estudo

LIVRARIADAFOLHA
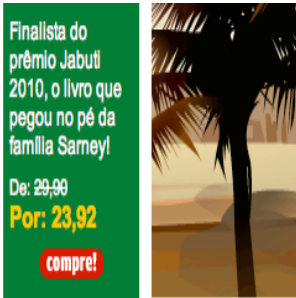

\section{follhashop}

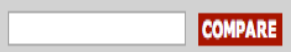

Auto Rádio

Diversos modelos a partir de R\$ 119

Kit de Maquiagem

Diversos tipos a partir de R\$ 39,90

Canon

$10 \mathrm{MP}$ a partir de $\mathrm{R} \$ 35$

a) semjuros

Celular Messenger Diversas cores a partir de ne 294
WS

Mochila para Noteboo Dlversos modelos a partir de R\$ 18

Gafisa SBC Soletro



Nova Petropolis. Apto 2 ou 3 suttes. 128 $155 m^{2}$

Sorana
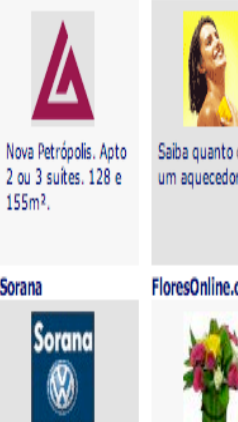

$$
\text { Floresonline.com,br }
$$

Clique aqui para fazer o mehor negócio em W.

Redfax - Agenda



Flores a partir Rs 34,00 em ate $3 X$ Envie Flores de Norte a Sul do BR.

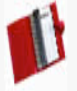

Couro natural em Vermentho $6 \times$ RS

48,35

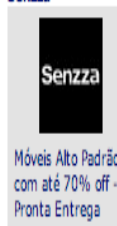


Figura (27) Folha Online, 28 de novembro de 2005 - Reportagem (2) ${ }^{67}$

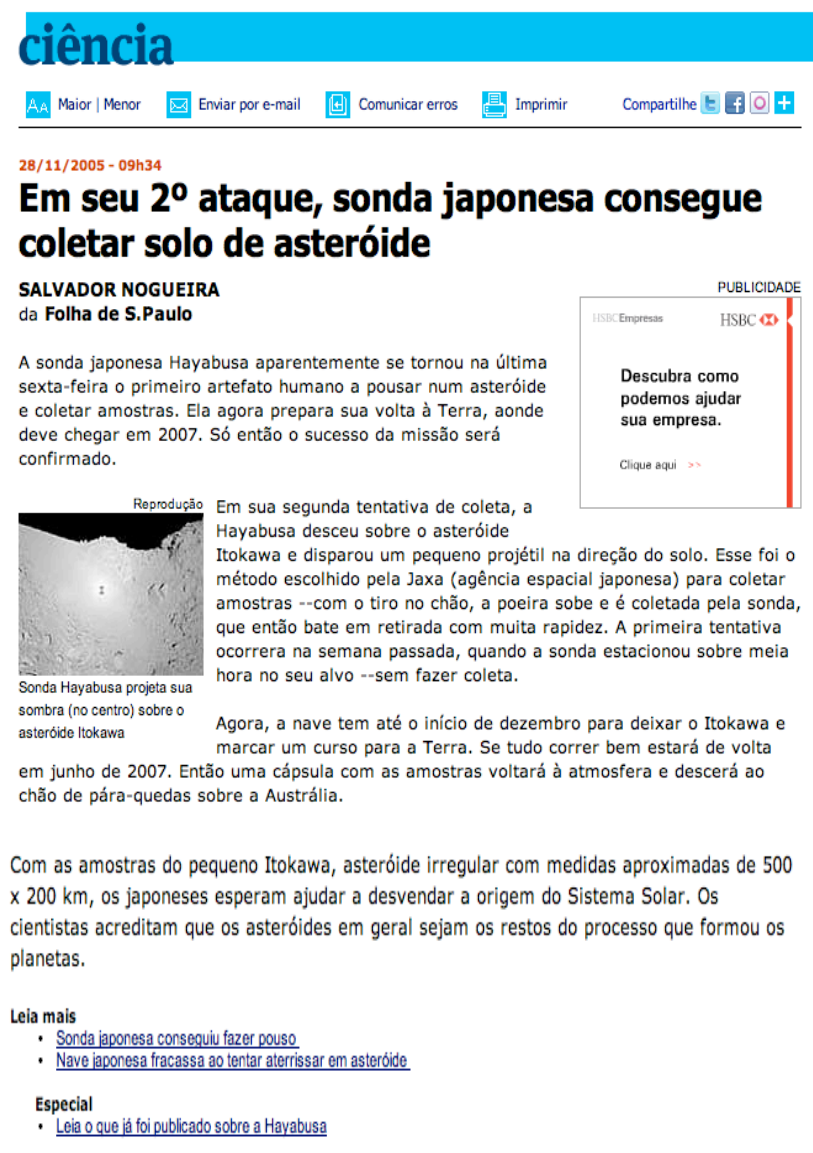

C

as últimas que você não leu

1. PMs confundem colega com assaltante e matam policial no Rio

2. Televisa e Lionsgate se unem para o público latino dos EUA

3. A R\$ 9,90 , "Homem Chavão" alerta para clichês na hora da morte de famosos

4. Justiça argentina condena padre pedófilo a 15 anos de prisão

5. Em Altamira, Serra diz que sabe bater pênalti

6. Figueirense perde para o AméricaMG e corre risco de sair da ponta da Série B

7. Bombeiros controlam incêndio na zona sul de SP; favela da zona leste é atinginda

8. TSE nega direito de resposta de Dilma em programa de Serra por conta de luz

9. Museu de Berlim expõe cerca de 50

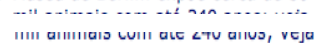

10. Cinema brasileiro é destaque em festival francês Biarritz

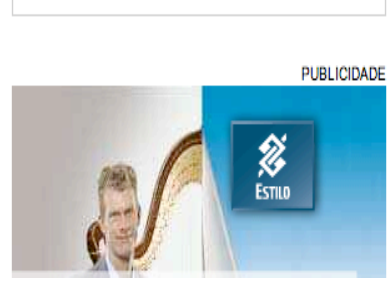

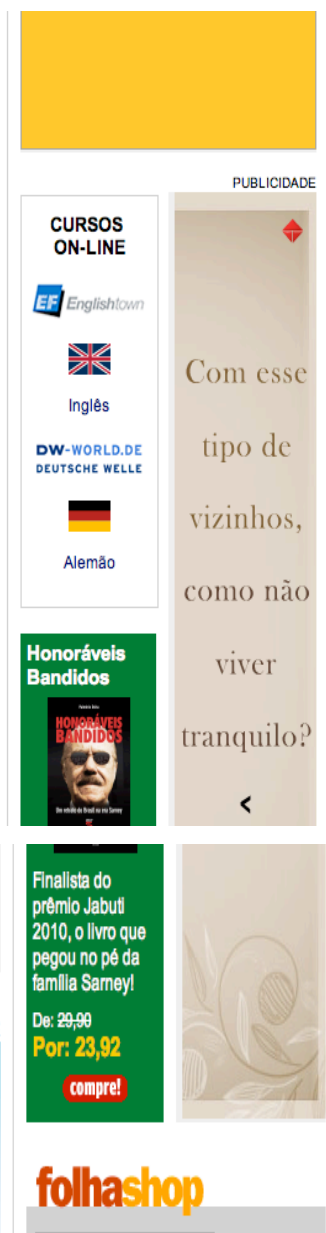

As reportagens de 2000 e 2005 ainda apresentam bastante semelhança no modo de dispor as reportagens, sobretudo na FSP. Na FO, já observamos um aproveitamento diferente dos nós remissivos e a configuração da página apresenta-se mais complexa por meio da indexação de nós remissivos eletrônicos. Comparando-se ao dossiê do ano 2000, a sugestão pela compilação de enunciados publicados anteriormente é possível somente em 2005, mesmo porque novembro de 2000 configura-se como o primeiro mês em que as reportagens de DC passaram a ser publicadas em meio digital, na FO. O sistema de indexação descrito no ano anterior prevalece em ambos os jornais e a FSP, inclusive, parece incorporar cada vez mais tal recurso, o que causou implicações de ordem temática como veremos a seguir.

\footnotetext{
${ }^{67}$ Disponível em: http://www1.folha.uol.com.br/folha/ciencia/ult306u14000.shtml. Acesso em: 19/05/2009.
} 


\subsubsection{O clima político e o clima ambiental}

A primeira reportagem da FSP, apesar de tratar de um aspecto vinculado à esfera científica, o efeito estufa, é atravessada pelo discurso político-econômico em âmbito mundial. $\mathrm{O}$ entrecruzamento dos dois discursos dá-se logo no chapéu sucedido pelo título auxiliar, cuja função é sintetizar as causas do possível fracasso das medidas que deveriam ser tomadas na reunião: Efeito Estufa: Impasse internacional e virtual do governo anfitrião ameaçam reunião sobre combate ao aquecimento.

$\mathrm{O}$ enunciado da FO não lança mão do mesmo recurso e, portanto, o tema final que resulta de suas relações de sentido é distinto. Trata-se de um exemplo sobre como aspectos tanto estilísticos e de forma composicional de cada publicação contribuem para a apreensão de determinado conteúdo temático. Na edição digital, o leitor deve conciliar a leitura do título e boa parte do enunciado para depreender a problemática que é antecipada tanto pelo chapéu quanto pelo título auxiliar na versão impressa do jornal.

O título da reportagem é o mesmo em ambas as publicações: Conferência começa sem clima no Canadá. Conforme afirmamos anteriormente, a bivocalidade presente no termo "sem clima" orienta argumentativamente a dupla intenção empregada pelo autor. Nesse caso, a primeira orientação do termo "sem clima" implica na falta de entendimento entre os países e às diferentes conjunturas políticas, a saber: o embate entre Europa e Estado Unidos sobre a diminuição dos poluentes, o que pode vir a causar prejuízos econômicos ao segundo; a delicada situação política do país que sedia o encontro por conta de um caso de corrupção; e a própria conjuntura política brasileira, retratada em um pequeno módulo textual à parte, ligado à reportagem principal. A segunda orientação realizada na intencionalidade do autor refere-se ao objeto de valor motivador do próprio evento: o clima enquanto uma unidade física, constitutivo do meio ambiente. A falta de clima político entre os governantes pode prejudicar o clima ambiental do planeta.

A segunda reportagem, aparentemente, não possui vínculo com a primeira. No entanto, se levarmos em conta que a discussão na reportagem principal trata de um assunto com dimensões internacionais, a reportagem sobre o lançamento da sonda japonesa exerce uma relação de complementariedade, reforçando os temas anteriores. A variante que une as duas reportagens e que pode ser considerada um nó remissivo entre elas é o Japão que é citado metonimicamente por meio do tratado de Kyoto na reportagem (1) e citado diretamente na reportagem (2), como um país que obteve êxito em um avanço científico. 
O Japão não somente fica fora da conjuntura política negativa no primeiro caso, surgindo como um cenário da edição anterior do evento, mas é exaltado na área científica na reportagem posterior. Chamamos a atenção para o fato de que para a parcela da sociedade que acompanha o histórico das Conferências Mundiais sobre o Clima, bem como para os leitores da seção Ciência, a conferência realizada em Kyoto havia sido a mais bem sucedida até aquele momento. $\mathrm{Na}$ versão digital, não há qualquer remissão entre os mesmos enunciados dispostos no jornal impresso, confirmando as observações da análise anterior.

\subsubsection{Indícios de expansão da cultura científica}

Enquanto na FSP, a reportagem é composta por um enunciado verbo-visual constituído pela imagem da sonda, juntamente com a legenda explicativa e os elementos do peritexto orientados para a primeira captação do leitor, a dimensão verbo-visual não se faz tão central no enunciado da FO, apesar de a função ser a mesma. Entretanto, o aparecimento da imagem na FO é uma característica essencial para o processo de expansão e fortalecimento das práticas de DC no veículo. Se anteriormente o enunciado digital era limitado pelo próprio processo de transposição de um meio a outro, a dimensão verbo-visual começa a aparecer, contribuindo para a complexificação da própria esfera científica digital. Abaixo, reproduzimos a imagem com sua respectiva legenda.

Figura (28) Folha Online, 28 de novembro de 2005 - Reportagem (2)

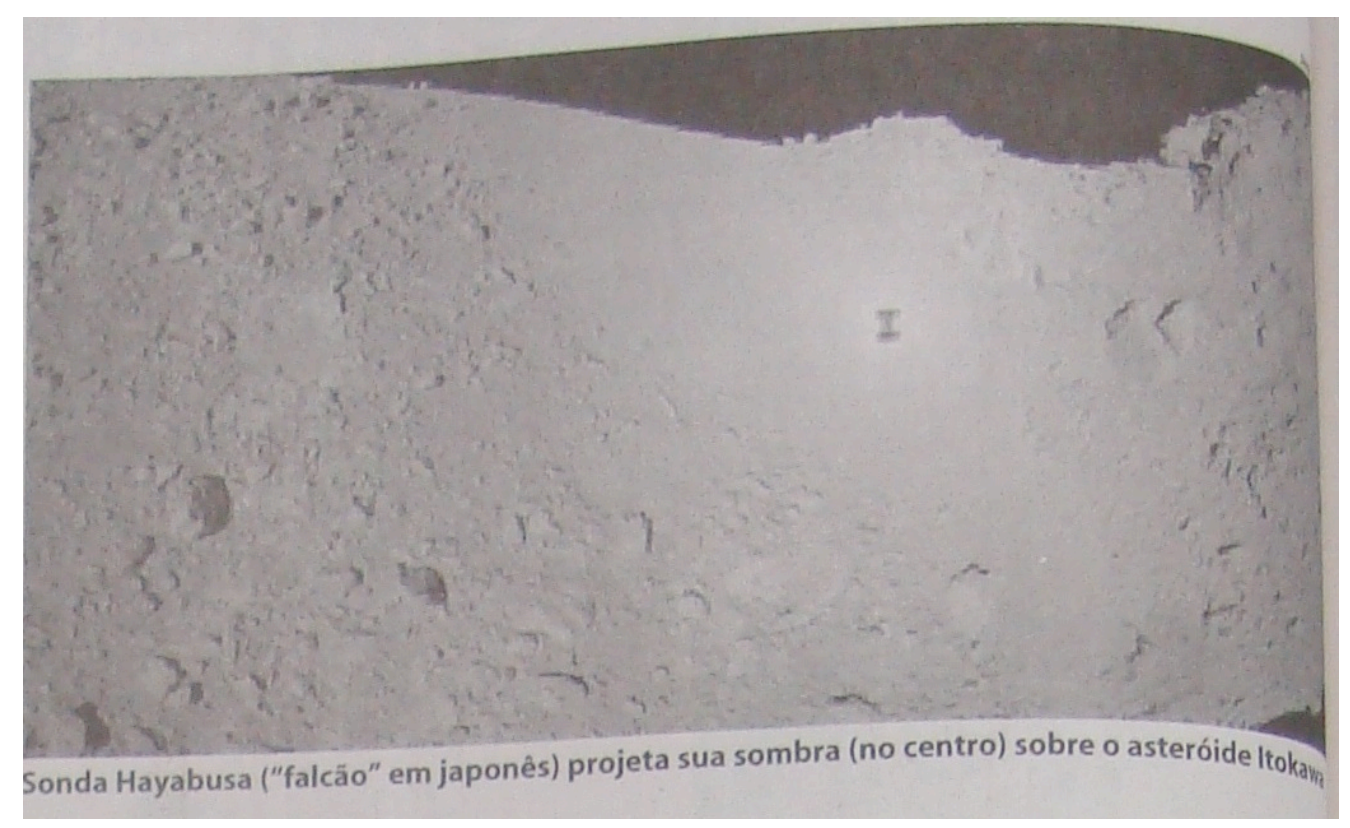


O sucesso atribuído à sonda japonesa não se deve somente ao fato de a sonda ter atingido uma grande proximidade com o asteróide, mas também pelo registro visual feito por ela. No caso, a sonda é autora da imagem e também personagem dela, uma vez que a sua sombra está projetada ao centro. A importância da fotografia condiz com o enunciado, sobretudo com o título auxiliar que indica uma possibilidade de sucesso da missão, que, no entanto, seria confirmada apenas em 2007: "Sucesso da Hayabusa só será confirmado em $2007 "$

Interpretamos o reflexo da sonda na imagem feita por ela mesma como uma comprovação de cunho científico. Em relação dialógica hipertextual com os elementos verbais, no plano interno primário, o elemento verbo-visual é uma forma de atribuir veracidade à descoberta científica e direciona a possibilidade de êxito da missão positivamente. Trata-se de mais uma relação dialógica hipertextual entre a dimensão verbal e verbo-visual do enunciado caracterizada pela legitimação da autoridade da esfera científica, feita pela indexação de uma imagem produzida por uma agência espacial. A relação dialógica de plano interno primário pode ser captada também na FO, indicando uma primeira mudança na esfera de produção de enunciados no meio digital.

Na publicação digital, o fortalecimento da prática do discurso de DC também é evidenciado pela indexação de nós eletrônicos, como observamos nos excertos abaixo:

Figura (29) - Reprodução de fragmento da reportagem Conferência começa sem clima no Canadá

$$
(\ldots)
$$

Até agora, a posição brasileira era a de não abordar o chamado desmatamento evitado --o que, aliás, será feito pela Costa Rica em Montréal. Com a nova proposta, ao mesmo tempo em que reconhece que é preciso fazer alguma coisa em relação às florestas, o Brasil se desobriga de uma redução compulsória de emissões.

Com "New York Times"

Leia mais

- Gás carbônico bate recorde de 650 mil anos

Especial

- Leia o que já foi publicado sobre aquecimento global

Na primeira reportagem, Conferência começa sem clima no Canadá temos relações dialógicas hipertextuais em dois planos externos distintos: o primeiro cumpre a função de complementação por inserção de dados novos, ancorada no título "Leia mais"; o segundo plano possui a mesma função, contudo, leva o interlocutor à página de busca do portal da FO, sugerindo que o leitor busque por informações livremente. 
Figura (30) - Reprodução da página de busca indexada à reportagem Conferência começa sem clima no Canadá

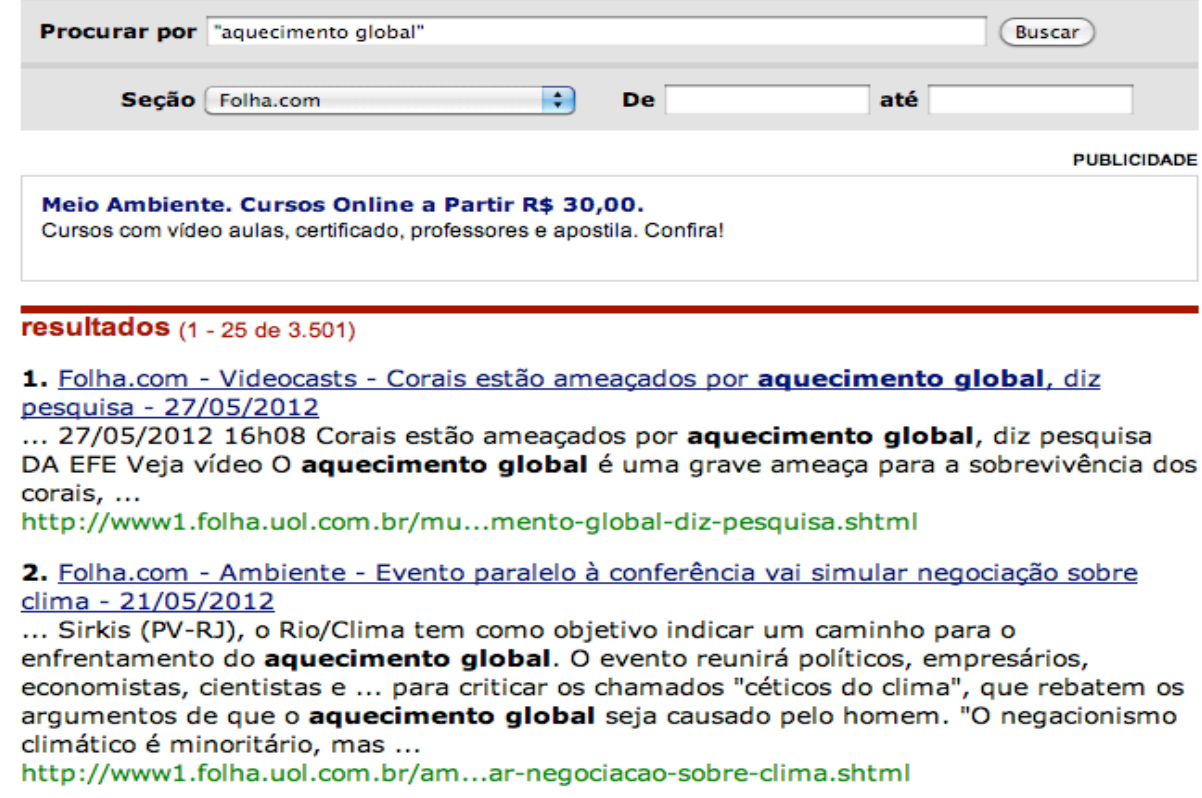

A segunda reportagem, Em seu segundo ataque, sonda japonesa consegue coletar solo de asteróides, o índice de nós remissivos ao final da reportagem é mais complexo com a inserção de mais um enunciado. A função dialógica dos enunciados indexados é o de reconstituir os eventos anteriores relacionados à sonda japonesa, resultando em uma relação dialógica hipertextual para complementação com caracterização do tempo-espaço envolvendo o evento do enunciado-fonte.

Figura (31) - Reprodução de fragmento da reportagem Em seu segundo ataque, sonda japonesa consegue coletar solo de asteróides

\section{(...)}

Com as amostras do pequeno Itokawa, asteróide irregular com medidas aproximadas de 500 x $200 \mathrm{~km}$, os japoneses esperam ajudar a desvendar a origem do Sistema Solar. Os cientistas acreditam que os asteróides em geral sejam os restos do processo que formou os planetas.

Leia mais

- Sonda japonesa consequiu fazer pouso

- Nave japonesa fracassa ao tentar aterrissar em asteróide

Especial

- Leia o que já foi publicado sobre a Hayabusa 
O segundo tipo de remissão ancorado pelo termo "Especial" também exerce função de complementação como apresentação de novos dados, exatamente como no exemplo da reportagem anterior. Diferentemente do que ocorre na FSP, a DC alcança maiores níveis de remissão na FO e as relações dialógicas hipertextuais são mais variadas.

O espaço dedicado aos anúncios publicitários reforça a discrepância entre o desenvolvimento das esferas que abrangem a DC nos dois meios, já que a FO apresenta um box relativamente pequeno em relação ao enunciado, enquanto a FSP fornece metade da totalidade de sua página a duas peças. Faz-se mister ressaltar que o dinamismo e a velocidade de atualização de informações na rede não prejudicaram o armazenamento das reportagens digitais, mas não permitem acessarmos os anúncios publicados na época de publicação da reportagem. Logo, não nos é possível avaliar as relações dialógicas, muito menos as unidades temáticas de tais enunciados da esfera publicitária em meio digital, como o fazemos na FSP.

\subsubsection{Síntese}

$\mathrm{Na}$ última análise do primeiro segmento selecionado que compreende os anos de 2000 a 2005, observamos mudanças no que tange às relações dialógicas hipertextuais em meio impresso e digital. No primeiro ano de análise, as reportagens digitais constituíam-se da mesma forma lógica das reportagens impressas, fato que perdurou até o momento. No entanto, a dimensão verbo-visual na FO não se formou a partir dos mesmos elementos verificados na FSP. Se considerarmos as possibilidades acarretadas pela tecnologia digital no processo de concretização de enunciados, notamos que as características do meio digital não foram absorvidas no processo de transposição da forma lógica do enunciado impresso, muito menos as características do meio impresso foram mantidas.

No ano inicial, a hipertextualidade foi bem marcada pela hiperestrutura na página do jornal impresso e a centralidade da dimensão verbo-visual, concentrada na imagem do presidente FHC. Enquanto isso, a FO articula as relações dialógicas hipertextuais por meio do nó eletrônico, tendência que se manteve ao longo de todos os anos analisados. A FSP, ao contrário, modifica o modo com que o eixo de sentido é estabelecido entre os enunciados e em, 2003, é o conteúdo temático que coloca os enunciados no mesmo plano semânticoaxiológico, sem lançar mão de um nó remissivo marcado por elementos verbais ou verbovisuais. 
Em 2005, chamou-nos a atenção o fato de que a indexação é confirmada como um processo que coloca enunciados em relação dialógica hipertextual, tanto em meio impresso quanto digital. Na FSP, a primeira reportagem indexa a segunda, ao passo que a FO vincula enunciados em plano externo secundário, ou seja, em um movimento do enunciado-fonte a enunciados que estão em outras páginas do jornal digital. $\mathrm{O}$ aparecimento da imagem legendada na FO também é um indício da consolidação da prática da DC na publicação, reflexo do estabelecimento da cultura científica como um todo no contexto sócio-histórico brasileiro. 


\section{CAPít́lulo 5.}

\section{A HIPERTEXTUALIDADE E A CONSOLIDAÇÃO DA CULTURA CIENTÍFICA NA FSP E NA FO}

$\mathrm{N}$ a segunda metade da década de 2000, o uso da internet era bem mais difundido entre usuários comuns em nível mundial e os gêneros discursivos produzidos no meio digital possuíam características mais estáveis, tal como o e-mail e os chats em salas de bate-papo. A interatividade entre usuários era cada vez mais absorvida como característica do meio, o que favoreceu a criação das recentes redes sociais, como o Orkut (2004), o Facebook (2004) e o Twitter (2006). A incorporação da rede mundial de computadores pela sociedade deu-se também nas esferas públicas, pelos domínios governamentais e empresas em geral - neste caso, fazendo com que a esfera publicitária fosse fortalecida no meio digital.

Tal processo também ocorreu no âmbito da DC, uma vez que a internet passou a constituir-se espaço importante para a veiculação de pesquisas, resultados e debates provenientes da esfera científica. Em 2006, uma significativa revista eletrônica de divulgação científica, Com Ciência - elaborada pelo LabJor (Laboratório de Jornalismo) da UNICAMP - sofreu uma profunda mudança na forma de apresentação do website, no que tange ao layout da diagramação e ao estilo, semelhante ao que ocorreu nas páginas impressas da FSP. 
Figura (32) Imagem do site Com Ciência em sua nova configuração a partir de $2006^{68}$.

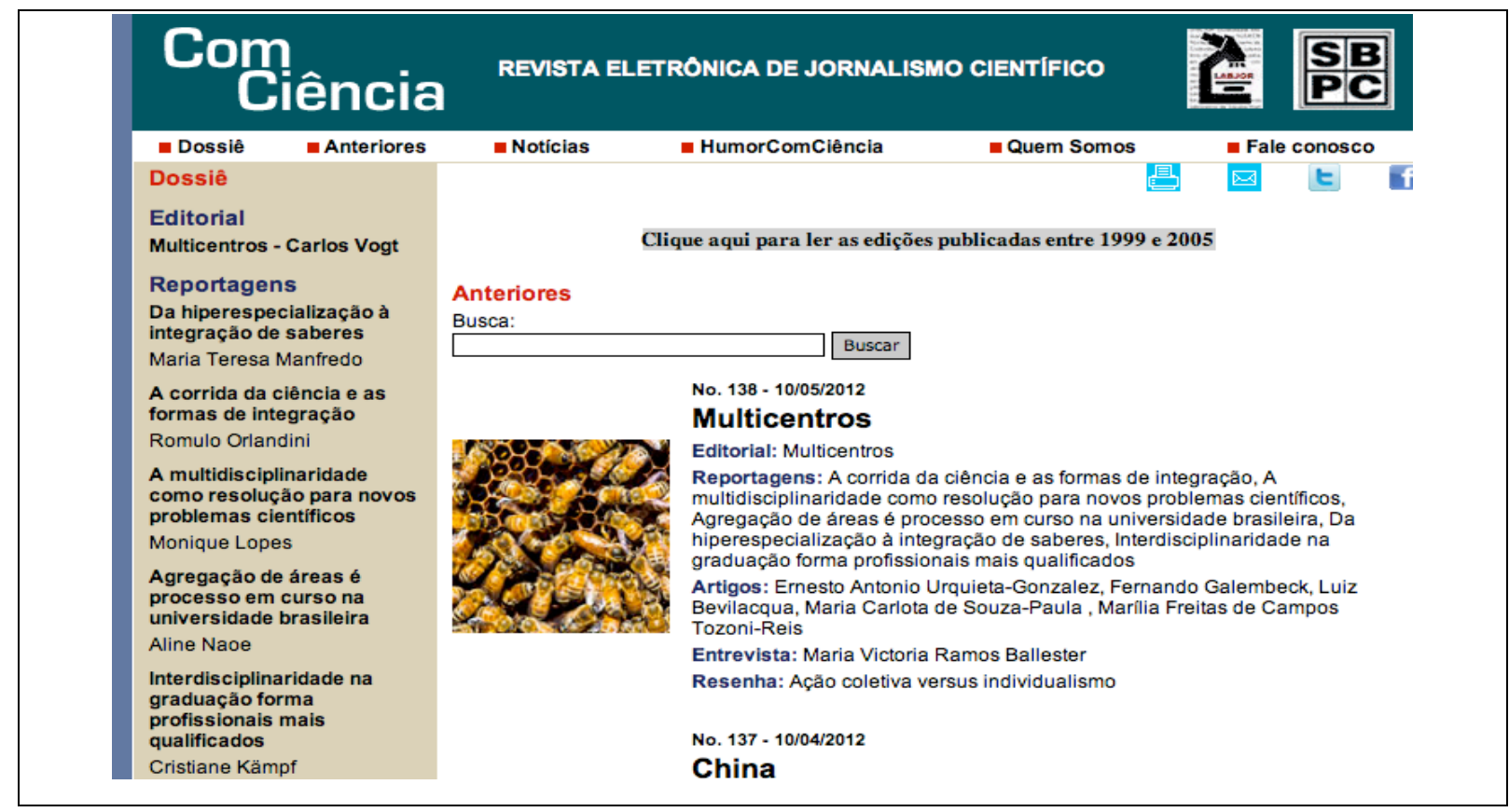

Já havíamos identificado indícios, ao longo da tese, de que o ano de 2006 foi determinante para inovações no tocante à forma de estruturação dos enunciados impressos, tanto que utilizamos tal critério para delimitar os capítulos de análise. A reconfiguração dos aspectos estilísticos e da forma composicional dos enunciados não pode ser considerada repentina ou aleatória, considerando as observações que fizemos no capítulo anterior. Apesar de não ter sido registrada nas novas edições do Manual da Redação ${ }^{69}$, é notável que os modos de produzir e veicular os enunciados, tanto da FSP quanto da FO, sofreram modificações importantes no segundo período de enunciados selecionados no corpus.

A consolidação da cultura científica brasileira coincide com a maior expansão da rede mundial de computadores, fatores imprescindíveis para nossa análise, sobretudo no quinto capítulo. Analisamos enunciados de reportagens dos anos de 2006, 2007 e 2008, com o intuito de compreender as possíveis estabilizações geradas pelo meio sobre o enunciado e o processo de complexificação da dimensão verbo-visual com a inserção de esquemas explicativos e elementos infográficos, considerando a mesma contextualização do panorama sócio-histórico global que apresentamos no início do capítulo anterior.

\footnotetext{
${ }^{68} \mathrm{Na}$ imagem, podemos notar que os dossiês de reportagem de 1999 a 2005 - cujo link é grifado de cor cinza são direcionados a outra página.

${ }^{69}$ O último Manual da Redação que consultamos data do ano de 2010.
} 
Sob o ponto de vista da forma composicional, partimos da verificação de que a conclusibilidade dos enunciados impressos e digitais dá-se de forma distinta no gênero reportagem de DC. Se na FSP, uma reportagem pode ser formada por um ou mais enunciados dispostos em uma única página do jornal, na FO, cada página comporta somente um enunciado, que, por sua vez, equivale a uma reportagem. Com isso, a unidade temática difere em cada meio e as relações dialógicas hipertextuais da FSP não são necessariamente mantidas na FO, apesar de a forma lógica ser a mesma em ambas as publicações. Inicialmente, o espaço dedicado à DC era visivelmente atravessado por temas da esfera política, sempre relacionados ao contexto sócio-histórico brasileiro, aspecto que sofreu alteração nas análises posteriores. $\mathrm{O}$ aparente apagamento do conteúdo temático estritamente relacionado à esfera política também pode ser verificado na dimensão verbo-visual dos enunciados. No tocante à constituição da verbo-visualidade, a FO, que primeiramente não veiculava imagens ou esquemas gráficos em seus enunciados, passou a fazê-lo em 2005.

\subsection{Retratos do homem pré-histórico e o ocultamento das questões políticas nacionais em reportagens do ano 2006}

O ano de 2006 foi marcado pelas eleições presidenciais que reelegeram o expresidente Luís Inácio Lula da Silva, no mês de outubro. Tal fato político não reverberou nos enunciados da seção "Folha Ciência". O "Primeiro Caderno", cuja única referência à reeleição de Lula são reportagens sobre o quadro ministerial do 'novo' governo, foca a derrota do partido de George W. Bush na eleição legislativa dos Estados Unidos. A centralidade dessa notícia, que se configurou como a principal entrada da primeira página, parecia ofuscar o momento em que Lula delineava a equipe de ministros. Talvez, não atribuir tamanha importância para as ações de Lula pudesse ser proposital, uma vez que o presidente demorava a divulgar os nomes dos ministros e mostrava-se interessado em manter a situação suspensa, como apontado na própria editoria da FSP, pela voz de Eliane Catanhêde no enunciado a seguir: 
Figura (33) Enunciado publicado no editorial da FSP no dia 10/11/2006

\section{Brincadeirinha}

BRASílLA - Lula está parecendo outro homem depois de reeleito com boa margem de votos e de centralizar no seu gabinete do Planalto as negociações políticas para compor o novo ministério. Ele adora.

Ontem, no Itamaraty, queimado de sol e sorridente, passou a exercitar uma das suas novas modalidades: confirmar ministros, para, em seguida, negar tudo. E ri, divertindo-se com a agonia dos coitados, que estăo loucos para ficar, dos candídatos, que estấo loucos para entrar, e dos jornalistas, que estão loucos para saber menos quem sai e mais quem fica quem entra.

Lula percebe e dá corda. Na quarta-feira, aproveitou-se de uma solenidade em que uns gatos pingados gritavam "fica, fica" para anunciar que era "o dia do fico". Pronto. A conclusão foi que o ministro Fernando Haddad estava confirmadíssimo na Educação. Estava? Não. Erabrincadeirinha.

Ontem, a cena se repetiu, numa área ainda mais sensivel: o Banco Central. Primeiro, Lula disse que não tinha por que trocar Henrique Meirelles (aquele que os próprios ministros tentam culpar pelos indices haitianos de crescimentos): "Para que tirar?".

Pronto. A conclusão foi que Meirelles estava confirmadíssimo. Fstava? Não. Ou melhor: pode até estar, mas Lula tratou de corrigir em segundos, "explicando" que não tinha confirmado nada. Pode estar confirmado, pode não estar, pode estar agora e năo estar depois.

$\hat{E}$ assim que a Esplanada dos Ministérios vai virando uma concentração de ministros ansiosos para mostrar serviço, bom humor e proximidade do chefe. Enquanto, fora dela, o PT, o PMDB e demais aliados lambem os lábios, famintos.

Lula já tem muita coisa da nova equipe na cabeca, e tanto Meirelles como Haddad devem ficar, mas ele não vai anunciar assim tão fácil. Pra que, se ele pode se divertir tanto $\mathrm{e}$ dar boas gargalhadas ainda um bom tempo com a aflição alheia?

elianec@uol.com.br

Como a própria jornalista assume, o presidente "ri, divertindo-se com a agonia dos coitados (ministros) que estão loucos para ficar, dos candidatos que estão loucos para entrar, e dos jornalistas (como ela) que estão loucos para saber menos quem sai e mais quem fica e entra". Mais adiante, uma reportagem do "Primeiro Caderno" descreve a situação comentada por Eliane Catanhêde:

Figura (34) Reportagem publicada no Primeiro Caderno da FSP no dia 10/11/2006

A8 brasil sexta-Fera, 10 DE Novembro DE 2006

FOLHADE S.PAULO

\section{'Para que tirar?', diz Lula sobre Meirelles}

Presidente sinaliza a jornalistas que deve manter presidente do BC, mas, indagado diretamente, evita confirmar decisão

'Todos os ministros vão ficar... até o último dia do ano', brinca petista, que diz năo existir nada sobre a ida de Jorge Gerdau ao governo ELIANE CANTANHĖDE
COLUNISTADAFOHAA EDUARDOSCOLESE PEDRODIASLEITE
DASUCURSAL DE BRASIIIA



Gerdau nega que vá para o ministério 
Por estar situada no "Primeiro Caderno", a editoria de ciência da FSP até então se mostrou um palco para o debate político ancorado em algum evento nacional ou internacional, mas que obrigatoriamente envolve questões de interesse para o Brasil. Entretanto, ao contextualizar os enunciados do mês de novembro de 2006, a partir de uma pesquisa feita sobre enunciados veiculados na FSP e na FO, pudemos apurar que a maioria das reportagens publicadas estava relacionada às descobertas arqueológicas, assim como as reportagens selecionadas para esta análise.

Certamente, somente ao final da análise das reportagens do segundo período é que poderemos esclarecer se o deslocamento das questões político-econômicas relacionadas ao Brasil foi algo pontual ao mês de novembro de 2006, ou se o espaço da editoria passou por uma mudança no tocante ao conteúdo temático dos enunciados que veicula, por conta da maior consolidação do discurso de DC. As reportagens, escritas por Marcelo Leite e pelo jornalista Rafael Garcia ${ }^{70}$ respectivamente, não estabelecem alguma relação dialógica aparente com os demais enunciados do jornal e sua orientação editorial da data. Contudo, a falta de resolução do governo em apresentar publicamente a lista de ministros pode estar relacionada com tal mudança no eixo temático da "Folha Ciência", ato compreendido pelos jornalistas como falta de comprometimento do governo com a imprensa e a sociedade brasileira. Seria o silenciamento do discurso político no espaço da DC um sinal de protesto ou o discurso científico sendo fortalecido e adquirindo autonomia no "Primeiro Caderno"? Se consideramos o segundo fator, ou seja, a DC sendo fortalecida nas páginas da FSP, é certo que essa modalidade dialógica ainda não desbancou o espaço destinado às peças publicitárias, que, neste caso, ocupam $50 \%$ do espaço da página, como podemos ver na imagem reproduzida do jornal na seção seguinte.

\subsubsection{Uma nova dimensão espacial no jornal impresso}

O ano de 2006 apresenta uma série de modificações tanto na FSP quanto na FO, sobretudo no quesito de demarcação das reportagens, da presença do hipertexto e das relações dialógicas hipertextuais estabelecidas entre os enunciados. Também foi o ano, entre 2000 e 2008, com o maior índice de veiculação de reportagens de divulgação científica na FO. Os aspectos observados revelam uma série de reorganizações da hiperestrutura,

\footnotetext{
${ }^{70}$ Garcia também possui formação em jornalismo científico, exigência que vem se cumprindo se analisarmos os autores dos anos anteriores.
} 
provavelmente motivadas por mudanças editoriais, mas, sobretudo, pela necessidade de adequação dos meios ao leitor presumido, que cada vez mais domina a tecnologia digital.

Dentre as diferenças estruturais apontadas anteriormente, a página da FSP não apresenta mais a demarcação das reportagens por meio dos chapéus e títulos auxiliares, que, por sua vez, passam a ser situados logo abaixo do título da reportagem. Logo, a demarcação passa a ser feita pelo tamanho da fonte dos títulos. Podemos observar que, nesta data, há somente uma reportagem que relaciona dois enunciados e a presença de dois elementos verbo-visuais. Conforme evidenciamos anteriormente, a versão impressa do jornal possui uma importante inserção que discutiremos mais adiante, a representação de um nó eletrônico. Por enquanto, seguimos apresentando a reprodução da página da FSP e seu esquema hiperestrutural referentes ao dia 10 de novembro de 2006 : 
Figura (35) Folha de S. Paulo, 10 de novembro de 2006

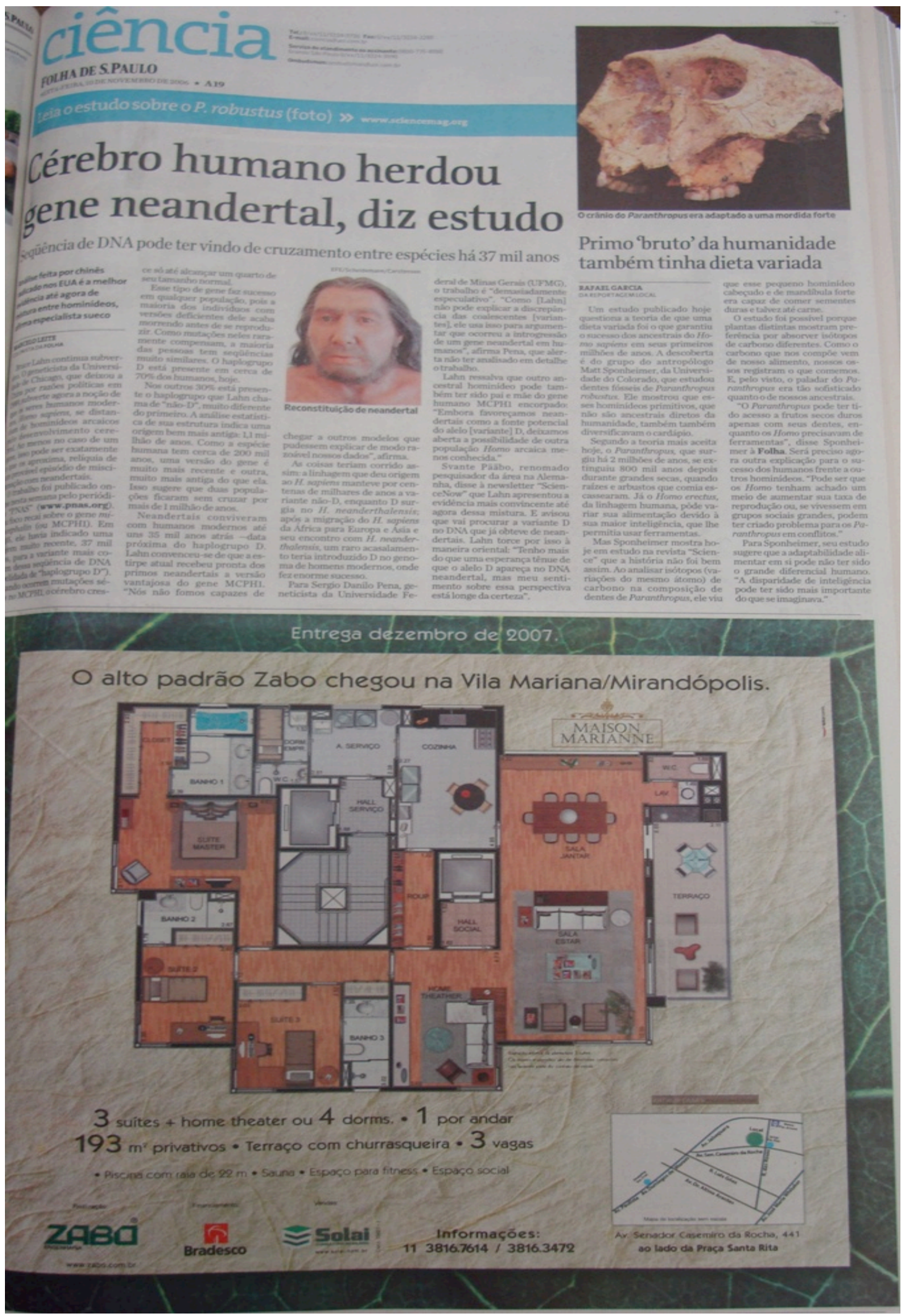


Tabela (10) Hiperestrutura da Folha de S. Paulo, 10 de novembro de 2006

\begin{tabular}{|c|c|c|}
\hline \multicolumn{3}{|r|}{ CABEÇALHO DA PÁGINA } \\
\hline CHAMADA & \multicolumn{2}{|c|}{ Leia o estudo sobe o P. Robustus (foto) $>>>$ www.sciencemag.org } \\
\hline $\begin{array}{l}\text { ELEMENTO } \\
\text { VERBO- } \\
\text { VISUAL }\end{array}$ & \multicolumn{2}{|c|}{$\begin{array}{l}\text { Foto do crânio do tipo humano indicado na chamada anterior com a legenda: "O crânio do } \\
\text { Paranthropus era adaptado a uma mordida forte" }\end{array}$} \\
\hline \multicolumn{3}{|r|}{ REPORTAGEM 1} \\
\hline \multirow{2}{*}{$\begin{array}{c}\text { ENUNCIADO } \\
1\end{array}$} & Título & Cérebro humano herdou gene neandertal, diz estudo \\
\hline & Título auxiliar & $\begin{array}{l}\text { Sequência de DNA pode ter vindo de cruzamento entre espécies há } 37 \text { mil } \\
\text { anos }\end{array}$ \\
\hline ELEMENTO & \multirow{2}{*}{\multicolumn{2}{|c|}{$\begin{array}{l}\text { Foto que caracteriza o homem retratado no texto com a seguinte legenda: "Reconstituição de } \\
\text { Neandertal" }\end{array}$}} \\
\hline $\begin{array}{l}\text { VERBO- } \\
\text { VISUAL }\end{array}$ & & \\
\hline $\begin{array}{l}\text { ENUNCIADO } \\
2\end{array}$ & Título & Primo 'bruto' da humanidade também tinha dieta variada \\
\hline \multicolumn{3}{|r|}{ ENUNCIADOS DE PUBLICIDADE } \\
\hline \multirow{2}{*}{ PEÇA 1} & Produto & Apartamento de alto padrão da construtora Zabo \\
\hline & $\begin{array}{l}\text { Chamada } \\
\text { principal }\end{array}$ & O alto padrão Zabo chegou na Vila Mariana/Mirandópolis. \\
\hline
\end{tabular}

A presença de anúncios no jornal impresso, além de apontar para o perfil de um leitor presumido de alto poder aquisitivo cuja faixa etária compreende pessoas mais velhas, corresponde a um módulo textual que ocupa metade da página da FSP, cujo espaço para veiculação de reportagens é mais restrito. Tal fato indica uma crescente em relação à caracterização do leitor presumido.

Os produtos anunciados parecem refletir, cada vez mais, os resultados da pesquisa encomendada pelo Grupo Folha no ano 2000. Naquela época, o leitor presumido foi caracterizado, em sua maioria, como o indivíduo, na faixa dos 40 anos de idade e com alto poder aquisitivo, ao passo em que a publicação impressa perdia o espaço de circulação entre os mais jovens. Este fenômeno parece se confirmar, uma vez que os anúncios estão cada vez mais voltados ao público mais maduro. No entanto, a captação do público jovem ainda constitui um interesse por parte da FSP, como observaremos na análise referente ao ano de 2008. Antes de prosseguirmos com a análise comparativa, apresentamos os enunciados da FO: 
Figura (36) Folha Online, 10 de novembro de 2006 - Reportagem (1), enunciado (1) ${ }^{71}$

\begin{tabular}{|c|c|c|c|}
\hline AA Maior | Menor 四 Enviar por e-mail & (6) Comunicar erros & 晅 Imprimir & Compartilhe $\mathrm{E}=\mathrm{f} 0 \mathrm{t}$ \\
\hline
\end{tabular}

10/11/2006 - $09 \mathrm{~h} 16$

\section{Cérebro humano herdou gene neandertal, diz estudo}

MARCELO LEITE

Colunista da Folha de S.Paulo

Bruce Lahn continua subversivo. 0 geneticista da Universidade de Chicago, que deixou a China por razões politicas em 1989, subverte agora a noção de que os seres humanos modernos, Homo sapiens, se distanciam de hominídeos arcaicos pelo desenvolvimento cerebral. Ao menos no caso de um gene, isso pode ser exatamente o que os aproxima, reliquia de um provável episódio de miscigenaçăo com neandertais.



O trabalho foi publicado on-line nesta semana pelo periódico "PNAS" (Www.pnas.org).

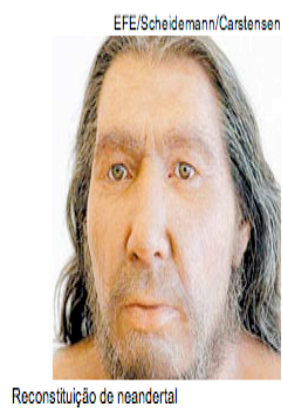

Seu foco recai sobre o gene microcephalin (ou MCPH1). Em 2005, ele havia indicado uma origem muito recente, 37 mil anos, para a variante mais comum dessa sequência de DNA (apelidada de "haplogrupo D"). Quando ocorrem mutações sérias no MCPH1, o cérebro cresce só até alcançar um quarto de seu tamanho normal.

Esse tipo de gene faz sucesso em qualquer população, pois a maioria dos individuos com versões deficientes dele acaba morrendo antes de se reproduzir. Como mutaçōes neles raramente compensam, a maioria das pessoas tem sequênncias muito similares. 0 haplogrupo D está presente em cerca de $70 \%$ dos humanos, hoje.

Nos outros 30\% está presente o haplogrupo que Lahn chama de "não-D", muito diferente do primeiro. A análise estatística de sua estrutura indica uma origem bem mais antiga: 1,1 milhão de anos. Como a espécie humana tem cerca de 200 mil anos, uma versão do gene é muito mais recente e outra, muito mais antiga do que ela. Isso sugere que duas populações ficaram sem cruzar por mais de 1 milhão de anos.

Neandertais conviveram com humanos modernos até uns 35 mil anos atrás --data próxima do haplogrupo D. Lahn convenceu-se de que a estirpe atual recebeu pronta dos primos neandertais a versão vantajosa do gene MCPH1. "Nós não fomos capazes de chegar a outros modelos que pudessem explicar de modo razoável nossos dados", afirma.

As coisas teriam corrido assim: a linhagem que deu origem ao $\mathrm{H}$. sapiens manteve por centenas de milhares de anos a variante não-D, enquanto $D$ surgia no $H$. neanderthalensis; após a migração do H. sapiens da África para a Europa e a Ásia e seu encontro com o H. neanderthalensis, um raro acasalamento teria introduzido $D$ no genoma de homens modernos, onde fez enorme sucesso.

Para Sergio Danilo Pena, geneticista da Universidade Federal de Minas Gerais (UFMG), 0 trabalho é "demasiadamente especulativo". "Como [Lahn] não pode explicar a discrepância das coalescentes [variantes], ele usa isso para argumentar que ocorreu a introgressão de um gene neandertal em humanos", afirma Pena, que alerta não ter analisado em detalhe o trabalho.

Lahn ressalva que outro ancestral hominídeo pode também ter sido pai e mãe do gene humano MCPH1 encorpado: "Embora favoreçamos neandertais como a fonte potencial do alelo [variante] D, deixamos aberta a possibilidade de outra população Homo arcaica menos conhecida".

Svante Pääbo, renomado pesquisador da área na Alemanha, disse à newsletter "ScienceNow" que Lahn apresentou a evidência mais convincente até agora dessa mistura. E avisou que vai procurar a variante $D$ no DNA que já obteve de neandertais. Lahn torce por isso à maneira oriental: "Tenho mais do que uma esperança tênue de que 0 alelo $D$ apareça no DNA neandertal, mas meu sentimento sobre essa perspectiva está longe da certeza".

Especial
L Leia o que ia foi publicado sobre neandertal
C Acompanhe a Folha.com no Twitter t

as últimas que vocênão leu

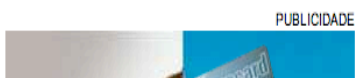

3. $\mathrm{A}$ R\$ 9,90 , "Homem Chavão" alerta para clichês na hora da morte de famosos

4. Justiça argentina condena padre pedófilo a 15 anos de prisão

5. Em Altamira, Serra diz que sabe bater pênalti

6. Figueirense perde para o AméricaMG e corre risco de sair da ponta da Série B

7. Bombeiros controlam incêndio na zona sul de SP; favela da zona leste é atinginda

8. TSE nega direito de resposta de Dilma em programa de Serra por conta de luz

9. Museu de Berlim expõe cerca de 50 mil animais com até 240 anos; veja

10. Cinema brasileiro é destaque em festival francês Biarritz

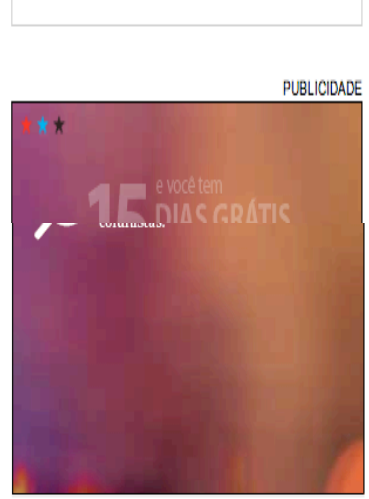

+ lidas

1. Exame de sangue pode detectar Alzheimer, diz estudo

2. Concurso para professor universitário ignora pós multidisciplinar

3. Cientista alerta sobre superbactéria resistente a quase todos antibióticos

4. Felicidade custa $\mathrm{R} \$ 11$ mil por mês, aponta estudo

5. Graduação não tradicional complica candidatura à vaga de professor + comentadas
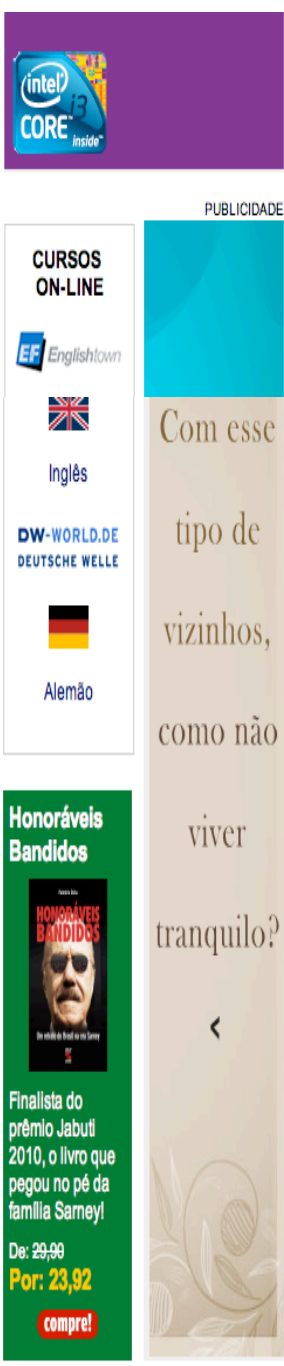

folhashop

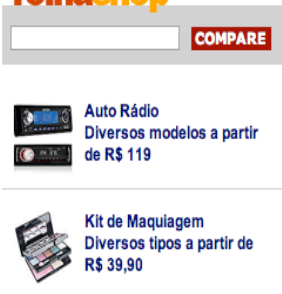

Canon

TOMP a partir de R\$ 359 sem juros

Celular Messenger Diversas cores a partir R\$ 324

Mochila para Notebook Diversos modelos a partir de R\$18





Figura (37) Folha Online, 10 de novembro de 2006 - Reportagem (1), enunciado (2) ${ }^{72}$

\section{ciência

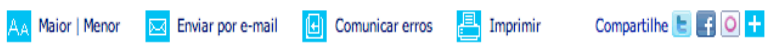 \\ 10/11/2006 - 11h 15 \\ Primo "bruto" da humanidade também tinha dieta variada}

\section{RAFAEL GARCIA \\ da Folha de S.Paulo}

Um estudo publicado hoje questiona a teoria de que uma dieta variada foi o que garantiu o sucesso dos ancestrais do Homo sapiens em seus primeiros milhões de anos. A descoberta é do grupo do antropólogo Matt Sponheimer, da Universidade do Colorado, que estudou dentes fósseis de Paranthropus robustus.

Ele mostrou que esses hominídeos primitivos, que não são ancestrais diretos da humanidade, também diversificavam 0 cardápio.

Segundo a teoria mais aceita hoje, o Paranthropus, que surgiu há 2 milhões de anos, se extinguiu 800 mil anos depois durante grandes secas, quando raizes e arbustos que comia escassearam. Já o Homo erectus, da linhagem humana, pôde variar sua alimentação devido à sua maior inteligência, que Ihe permitia usar ferramentas.

Mas Sponheimer mostra hoje em estudo na revista "Science" (www.sciencemag.org) que a história não foi bem assim. Ao analisar isótopos (variações do mesmo átomo) de carbono na composição de dentes de Paranthropus, ele viu que esse pequeno hominídeo cabeçudo e de mandíbula forte era capaz de comer sementes duras e talvez até carne.

0 estudo foi possivel porque plantas distintas mostram preferência por absorver isótopos de carbono diferentes. Como o carbono que nos compõe vem de nosso alimento, nossos ossos registram o que comemos. E, pelo visto, o paladar do Paranthropus era tão sofisticado quanto o de nossos ancestrais.

"O Paranthropus pode ter tido acesso a frutos secos duros apenas com seus dentes, enquanto os Homo precisavam de ferramentas", disse Sponheimer à Folha. Será preciso agora outra explicação para o sucesso dos humanos frente a outros hominideos. "Pode ser que os Homo tenham achado um meio de aumentar sua taxa de reprodução ou, se vivessem em grupos sociais grandes, podem ter criado problema para os Paranthropus em conflitos."

Para Sponheimer, seu estudo sugere que a adaptabilidade alimentar em si pode não ter sido o grande diferencial humano. "A disparidade de inteligência pode ter sido mais importante do que se imaginava."

Leia mais

- Cérebro humano herdou gene neandertal, diz estudo

Especial

- Leia que iá foi publicado sobre neandertal
C Acompanhe a Folha.com no Twitter te

as últimas que vocênão leu

1. PMs confundem colega com assaltante e matam policial no Rio

2. Televisa e Lionsgate se unem para 0 público latino dos EUA

3. A R\$ 9,90 , "Homem Chavão" alerta para clichês na hora da morte de famosos

4. Justiça argentina condena padre pedófilo a 15 anos de prisão

5. Em Altamira, Serra diz que sabe bater pênaltí

6. Figueirense perde para 0 AméricaMG e corre risco de sair da ponta da Série B

7. Bombeiros controlam incêndio na zona sul de SP; favela da zona leste é atinginda

8. TSE nega direito de resposta de Dilma em programa de Serra por conta de luz

mil animais com até 240 anos; veja

10. Cinema brasileiro é destaque em festival francês Biarritz PUBLICIDADE
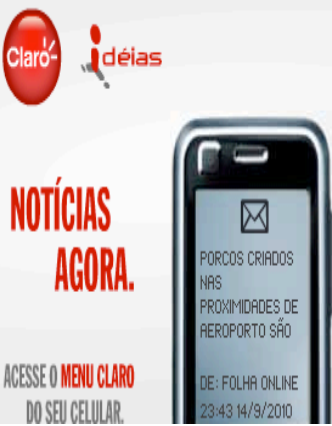
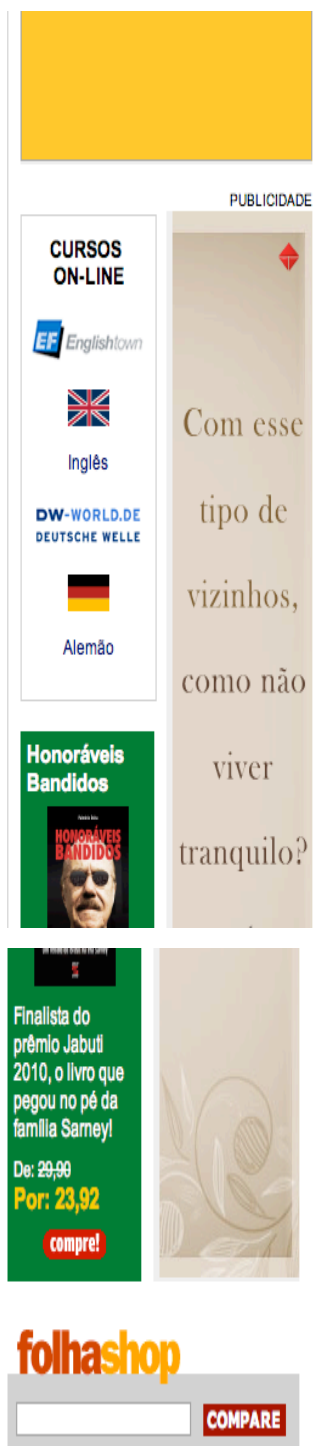

Auto Rádio

Diversos modelos a partir de R\$ 119

$\mathrm{Na} F \mathrm{~F}$ a relação do primeiro enunciado com o segundo pode desaparecer, de acordo com o percurso feito pelo leitor. Se acessar o enunciado (1) na internet, o leitor não encontra o nó remissivo para o enunciado (2), mas o contrário é possível. O enunciado (2) traz um nó que remeterá ao enunciado anterior. Há ainda a ocorrência de relação dialógica hipertextual por meio de outros nós.

\footnotetext{
${ }^{72}$ Disponível em: http://www1.folha.uol.com.br/folha/ciencia/ult306u15490.shtml. Acesso em: 19/05/2009.
} 
Em ambos os enunciados, notamos a referência ao site da revista Science, sendo curioso que, na $\mathrm{FO}$, o nó remissivo não é eletrônico, ou seja, não está digitalmente articulado, mas somente representado. Tal fato constitui uma possibilidade única para o meio impresso, a representação do hiperlink, uma vez que o impresso não permite o redirecionamento ao enunciado indicado. No entanto, seria possível o nó constituir um nó eletrônico no meio digital.

Esta é mais uma constatação de que os tipos de mecanismos de nós remissivos podem variar não somente por fatores limítrofes de cada meio, mas também por escolha do autor ou editor do jornal. $\mathrm{O}$ direcionamento a uma página externa pode não ser interessante por afastar o leitor usuário da rede do texto-fonte, logo, pode ser que a estratégia empregada na FO seja a de não vincular o hiperlink a endereço de sites externos. Por outro lado, o mesmo fragmento na FSP é evidenciado por meio das letras em negrito. O mesmo ocorre com o endereço eletrônico de um periódico intitulado PNAS. Apesar de o endereço ser eletrônico, a sua representação é impressa na FO.

Há outro tipo de remissão por meio de nó não marcado pelo link eletrônico na FO. No enunciado (2), ao descrever que a entrevista do cientista foi concedida à FSP, o termo 'Folha' foi colocado em evidência por meio da fonte em negrito. Trata-se da remissão de uma publicação à outra de natureza não digital. Dentre os tipos variados de hipertextualidade articulada pelo nó remissivo tanto em meio digital quanto impresso, um modo particular de remissão hipertextual nos chamou a atenção. Trata-se do cabeçalho disposto na FSP com a indicação de leitura de um estudo que complementa os enunciados (1) e (2). Além da indicação da leitura, este enunciado constitui-se verbo-visual, uma vez que está diretamente relacionado com a imagem do crânio do homem P. Robustus indicado pelo título.

\subsubsection{A hipertextualidade reconfigurada na dimensão verbo-visual}

Em 2006, a verbo-visualidade apresentou variações nos dois jornais: enquanto o estilo e a forma composicional da FSP foram modificados a partir da presença de um novo layout, a FO exibia uma imagem no interior de um dos seus enunciados, a mesma publicada no jornal impresso. Nesta seção, buscamos verificar que relações dialógicas hipertextuais podem ser averiguadas na dimensão hipertextual dos enunciados em questão. No jornal impresso, a dimensão verbo-visual possui diversos elementos, como destacamos da figura seguinte: 


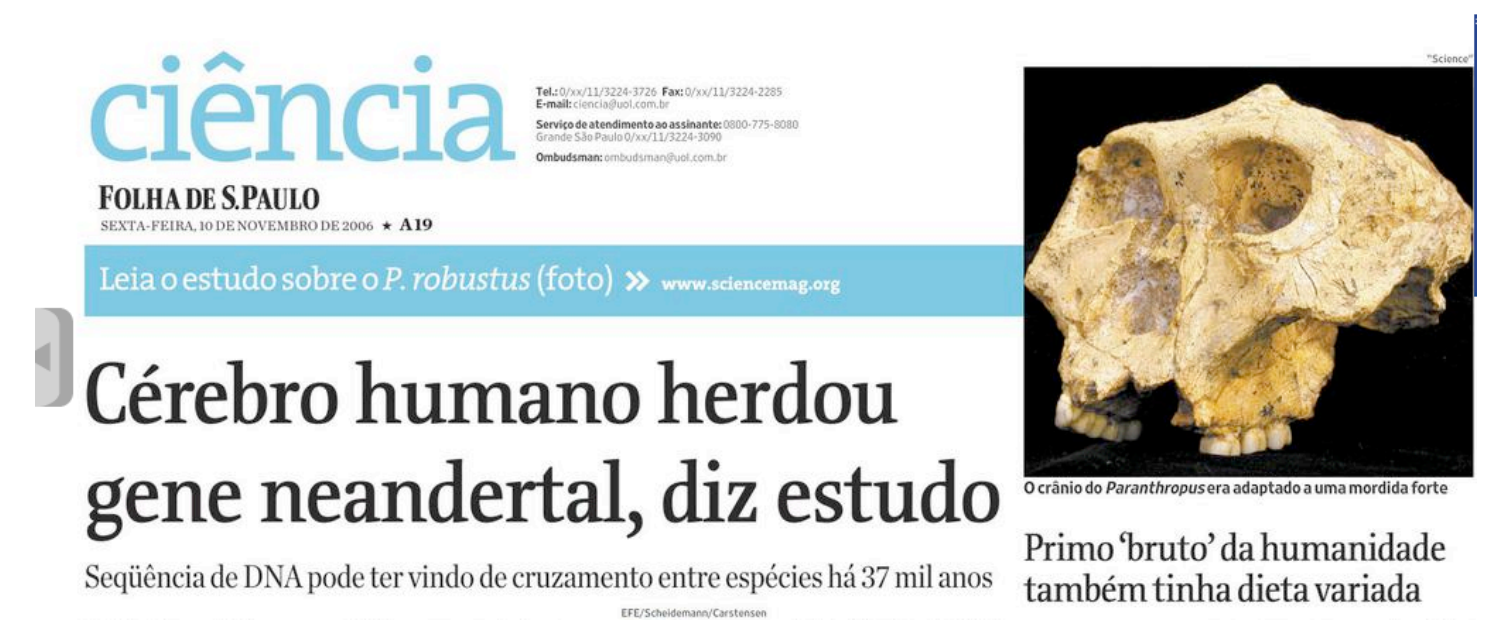

O trecho "Leia o estudo sobre P. Robustus", sobre um fundo azul no topo da página, funciona como um cabeçalho que indexa os dois enunciados que seguem abaixo: Cérebro humano herdou gene neandertal, diz estudo e Primo 'bruto' da humanidade também tinha dieta variada. O cabeçalho, entretanto, constitui-se como um enunciado autônomo e opera a hipertextualidade em dois planos: primeiro, ao remeter a enunciados da própria página em plano interno secundário, e segundo, ao articular uma relação dialógica com os enunciados da revista Science Mag, tal como propõe o fragmento: "Leia o estudo sobre o P. Robustus >> www.sciencemag.org".

Em ambos os casos, a relação dialógica é a mesma, tratando-se de uma complementação para adição de uma nova informação ao enunciado. A dimensão verbovisual do cabeçalho ainda é formada por uma fotografia legendada do crânio do P. Robustus, cuja função é apresentar elementos da esfera científica como forma de legitimação e atribuição de credibilidade ao conteúdo científico.

O tamanho das fontes dos títulos também revela a relação dialógica hipertextual estabelecida entre os dois enunciados da página impressa, tornado visível que o primeiro é o enunciado-fonte, tendo o segundo de menor extensão ligado a ele. A primeira reportagem trata de um estudo considerado especulativo sobre a verdadeira linhagem de origem do homem neandertal, o que contraria o atual estado da arte sobre a evolução do homem préhistórico. O segundo enunciado também discorre sobre aspectos dos hominídeos primitivos estabelecendo uma relação dialógica hipertextual com o enunciado-fonte de complementação por meio de novas informações. Essa relação dialógica não é articulada 
somente pela posição da indexação frente aos demais elementos da página. $\mathrm{O}$ advérbio "também" no título do segundo enunciado é dotado de uma ambiguidade que em uma de suas interpretações é articuladora da relação dialógica. $\mathrm{O}$ advérbio configura-se como uma palavra bivocal atravessada pela hipertextualidade na remissão entre o enunciado-fonte e o enunciado atual, bem como orientada para seu próprio discurso. Em 'Primo bruto' da humanidade também tinha dieta variada compreendemos:

a) que além da descoberta sobre a origem genética do homem das cavernas, tal como relatado no enunciado-fonte, também foi descoberto que sua dieta era variada, fato que levou à evolução dos hominídeos;

b) que assim como o homem Paranthrobus, o Hommo Erectus possuía uma dieta rica em diferentes nutrientes.

Tanto a FO quanto a FSP veiculam a imagem da reconstituição do homem neandertal em suas páginas, uma característica que não se observava na FO em anos anteriores. Ao inserir a imagem, procura-se legitimar a descoberta como um conteúdo da esfera científica, ilustrando ao leitor a face do homem primitivo, que entra em relação dialógica tanto de complementação para a adição do novo quanto de complementação para estabelecimento do tempo-espaço, uma vez que esta é a figura de um homem que possui um valor histórico. Trata-se de toda uma era humana representada na figura do neandertal e não de um homem específico cuja identidade nos é conhecida. Abaixo, destacamos a página da FO: 


\section{0/11/2006 - 09h16 \\ Cérebro humano herdou gene neandertal, diz estudo

\author{
MARCELO LEITE \\ Colunista da Folha de S.Paulo
}

Bruce Lahn continua subversivo. O geneticista da Universidade de Chicago, que deixou a China por razões políticas em 1989, subverte agora a noção de que os seres humanos modernos, Homo sapiens, se distanciam de hominídeos arcaicos pelo desenvolvimento cerebral. Ao menos no caso de um gene, isso pode ser exatamente o que os aproxima, relíquia de um provável episódio de miscigenação com neandertais.

O trabalho foi publicado on-line nesta semana pelo periódico "PNAS" (www.pnas.org).

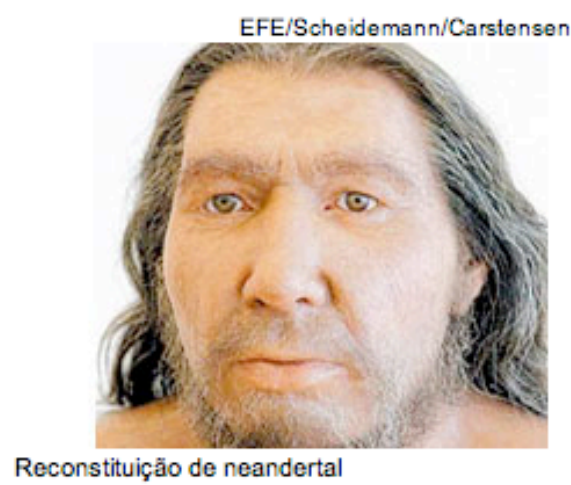

Seu foco recai sobre o gene microcephalin (ou MCPH1: Em 2005, ele havia indicado uma origem muito recentı 37 mil anos, para a variante mais comum dessa seqüência de DNA (apelidada de "haplogrupo D"). Quando ocorrem mutações sérias no MCPH1, o cérebre cresce só até alcançar um quarto de seu tamanho normal.

Esse tipo de gene faz sucesso em qualquer população, pois a maioria dos indivíduos com versões deficientes dele acaba morrendo antes de se reproduzir. Como mutações neles raramente compensam, a maioria das

\subsubsection{Os nós remissivos e os planos de remissão hipertextual}

Pela primeira vez, notamos que um nó remissivo do jornal impresso resulta em uma remissão externa de tipo secundário, ou seja, que extrapola os limites bidimensionais da página impressa. Tal tipo de remissão é mais produtivo do meio digital ao impresso. A indicação de um endereço eletrônico, por meio da representação impressa de hiperlinks (www.sciencemag.com e www.pnas.org), articula uma remissão externa à página. $\mathrm{O}$ fato de ser direcionado a um site em língua inglesa, órgão que não pertence a nenhum segmento do Grupo Folha, também se configura importante no processo de atribuição de maior grau de informatividade que se almeja no gênero reportagem - aliás, uma estratégia para que o jornal não assuma posicionamentos em momento de indefinição do cenário político brasileiro.

O nó remissivo eletrônico representado no impresso, cuja função é a de garantir maior informatividade e um deslocamento do leitor à esfera científica, já que o portal 
indicado pertence a um órgão dessa esfera, é uma evidência do afastamento da esfera política sobre a editoria da "Folha Ciência", corroborando, ao mesmo tempo, nossa hipótese de que a cultura científica está sendo cada vez mais disseminada no país e incorporada pelas publicações da Folha. Em seguida, apresentamos um exemplo de representação de nó remissivo eletrônico no enunciado-fonte do jornal impresso.

Figura (40) - Reprodução de fragmento da reportagem da FSP Cérebro humano herdou gene neandertal, diz estudo

\section{Análise feita por chinês radicado nos EUAé a melhor evidência até agora de mistura entre hominideos, afirma especialista sueco}

\section{MARCELOLEITE \\ COLUNISTADAFOLHA}

Bruce Lahn continua subversivo. O geneticista da Universidade de Chicago, que deixou a China por razōes políticas em 1989, subverte agora a noção de que os seres humanos modernos, Homo sapiens, se distanciam de hominideos arcaicos pelo desenvolvimento cerebral. Ao menos no caso de um gene, isso pode ser exatamente o que os aproxima, relíquia de um provável episódio de miscigenaçâo com neandertais.

O trabalho foi publicado online nesta semana pelo periódico "PNAS" (www.pnas.org). Seu foco recai sobre o gene $\mathrm{mi}$ crocephalin (ou MCPH1). Em 2005 , ele havia indicado uma ce só até alcançar um quarto de seu tamanho normal.

Esse tipo de gene faz sucesso em qualquer população, pois a maioria dos individuos com versôes deficientes dele acaba morrendo antes de se reproduzir. Como mutações neles raramente compensam, a maioria das pessoas tem sequêencias muito similares. O haplogrupo D está presente em cerca de $70 \%$ dos humanos, hoje.

Nos outros $30 \%$ está presente o haplogrupo que Lahn chama de "não- $\mathrm{D}$ ", muito diferente do primeiro, A análise estatística de sua estrutura indica uma origem bem mais antiga: $1,1 \mathrm{mi}-$ lhão de anos. Como a espécie humana tem cerca de $200 \mathrm{mil}$ anos, uma versão do gene é muito mais recente e outra, muito mais antiga do que ela. Isso sugere que duas populações ficaram sem cruzar por mais de 1 milhão de anos.

Neandertais conviveram com humanos modernos até uns 35 mil anos atrás -data

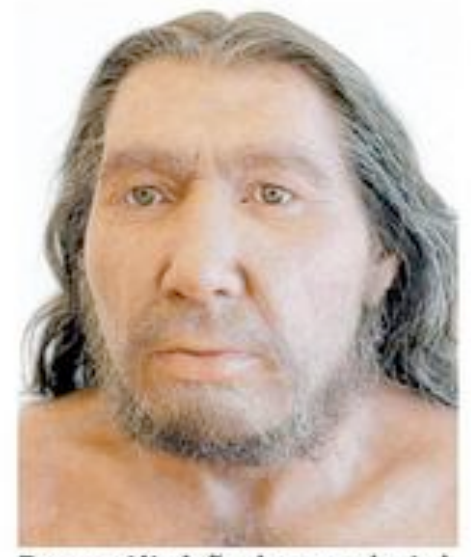

Reconstituiçăo de neandertal

chegar a outros modelos que pudessem explicar de modo razoável nossos dados", afirma.

As coisas teriam corrido assim: a linhagem que deu origem ao $H$. sapiens manteve por centenas de milhares de anos a variante não-D, enquanto $\mathrm{D}$ surgia no $H$. neanderthalensis; após a migração do $H$. sapiens da África para Europa e Ásia e seu encontro com $H$. neander-

$\mathrm{Na} \mathrm{FO}$, o uso de nós remissivos eletrônicos segue a mesma tendência observada em 2005. O plano de remissão pode ser para complementar o sentido do enunciado-fonte por meio da adição de novas informações, ou para situar o enunciado de acordo com os eventos anteriores a ele, caracterizando o tempo-espaço que o envolve. Selecionamos os nós remissivos dos dois enunciados de 2006: 
Figura (41) - Reprodução de fragmento da reportagem da FO Cérebro humano herdou gene neandertal, diz estudo

\section{$(\ldots)$}

Svante Pääbo, renomado pesquisador da área na Alemanha, disse à newsletter "ScienceNow" que Lahn apresentou a evidência mais convincente até agora dessa mistura. E avisou que vai procurar a variante D no DNA que já obteve de neandertais. Lahn torce por isso à maneira oriental: "Tenho mais do que uma esperança tênue de que o alelo D apareça no DNA neandertal, mas meu sentimento sobre essa perspectiva está longe da certeza".

Especial

- Leia o que já foi publicado sobre neandertal

Figura (42) - Reprodução de fragmento da reportagem da FO Primo "bruto" da humanidade também tinha dieta variada

\section{$(\ldots)$}

Para Sponheimer, seu estudo sugere que a adaptabilidade alimentar em si pode não ter sido o grande diferencial humano. "A disparidade de inteligência pode ter sido mais importante do que se imaginava."

Leia mais

- Cérebro humano herdou gene neandertal, diz estudo

Especial

- Leia o que já foi publicado sobre neandertal

O segundo enunciado é mais complexo no que tange ao plano hipertextual, pois apresenta os dois tipos de relação dialógica apontados anteriormente, revelando que a relação entre o segundo enunciado com o enunciado-fonte que observamos na FSP é mantido também na FO.

\subsubsection{Síntese}

Os dados que mais chamam a atenção nos enunciados do ano de 2006 são a nova configuração do espaço da página impressa e o enriquecimento da dimensão verbo-visual na FO com a inserção de imagem. Uma mudança estilística na forma de veicular conteúdos na FSP decorreu também de uma mudança no plano arquitetônico: o título auxiliar não antecede mais o título da reportagem principal. Ao invés disso, o título da reportagem, em letras maiores, demarca espacialmente as reportagens juntamente com elementos verbo-visuais.

A novidade está calcada na presença de um cabeçalho grifado em azul com uma indicação de leitura complementar aos assuntos tratados em ambas as reportagens. É a 
primeira vez em nosso corpus impresso que constatamos não somente a presença de um nó remissivo em reportagens, mas que, além disso, remete a um plano externo às fronteiras do jornal impresso e das publicações do Grupo Folha. Tal cabeçalho termina com uma fotografia do crânio de um homem pré-histórico e possui uma função não só ilustrativa, mas também coesiva em relação aos demais enunciados dispostos na página. As relações dialógicas hipertextuais tornaram-se mais complexas e estão igualmente presentes em ambos os jornais, variando apenas quanto ao plano de remissão em que se encontram. Enquanto na FSP há mais remissões de planos internos primários ou secundários, na FO observamos mais remissões externas.

\subsection{A soberania da esfera científica sobre a política em 2007}

O ano de 2007 marca um evento sem precedentes no corpus selecionado em nossa pesquisa: o discurso de DC rompe os limites da editoria de ciência constituindo-se em um dos elementos centrais da primeira página do jornal impresso. Se em 2006 já havíamos notado certo esvaziamento dos temas da esfera política na editoria e o descolamento de posicionamentos contundentes do jornal o espaço dedicado à DC, agora, além do espaço privilegiado conquistado no "Primeiro Caderno", observamos o enriquecimento da dimensão verbo-visual pela inserção de esquemas explicativos e infográficos. Aparentemente, não há relação dialógica em plano externo primário entre os enunciados do caderno a não ser uma importante relação dialógica hipertextual entre o enunciado da capa com o enunciado-fonte da página selecionada para análise. A posição ocupada pelo enunciado é privilegiada na hiperestrutura da primeira página, situada no alto, logo abaixo do cabeçalho do jornal. A antecipação do enunciado-fonte na parte interna do caderno visa à captação do leitor presumido. 
Figura (43) - Reprodução da primeira página da FSP de 15 de novembro de 2007

\section{FOLHA DE S.PAULO}



\section{Luladefende democracia deChávez}



Terremotono Chile provoca tremores Sīo Paule

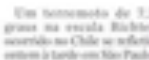

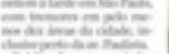 $\frac{25}{25-15}$

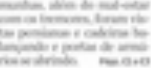

Eonomistas que criticam politica econòmica slo afastados do lipea

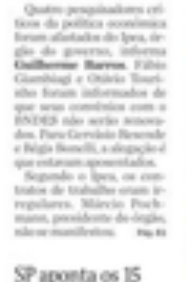

SPapoetaes is pions treches nas stralis estaduai

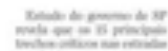

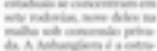
tivising

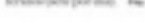

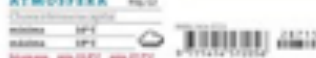

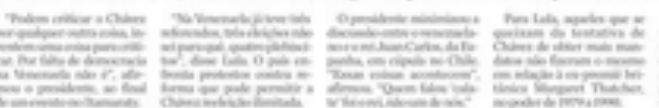

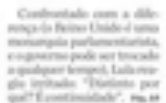

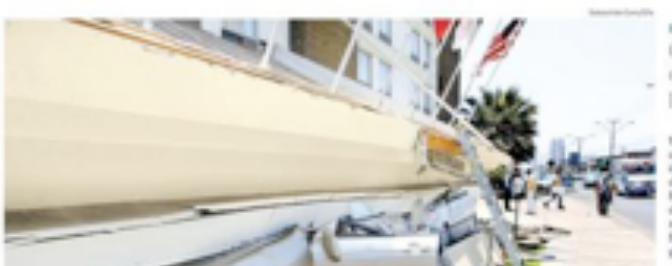

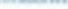
onfentinciasd undemagosos
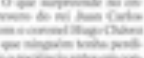

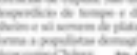

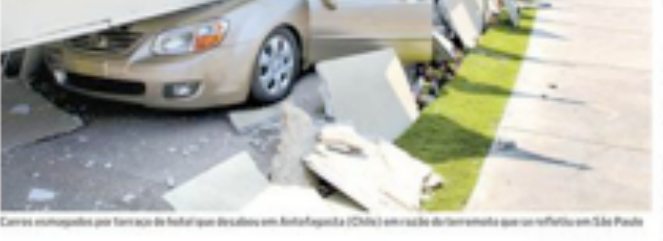

Nowo pedidode cassaçiode Renan passa emconselho
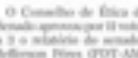

teriamo
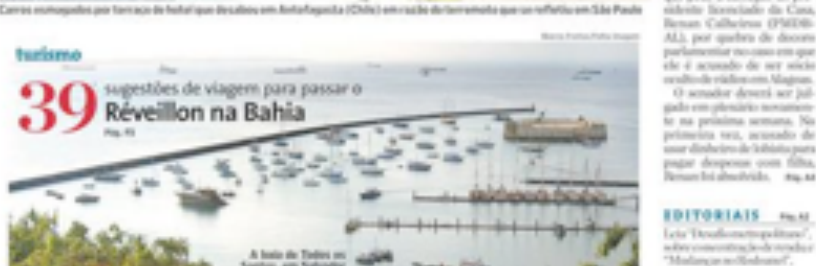
etron
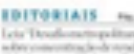

epente

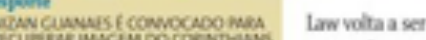

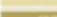

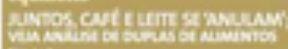
presoeterm sees Shopping lacrado

Aluntrada

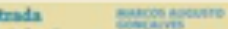

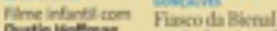

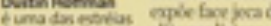

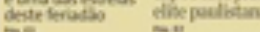


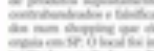

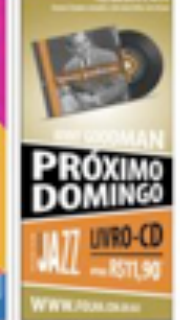

$\mathrm{O}$ enunciado acima disposto na primeira página, refere-se imediatamente à reportagem que dispomos abaixo, seguida de sua respectiva tabela de organização hiperestrutural: 
Figura (44) Folha de S. Paulo, 15 de novembro de 2007

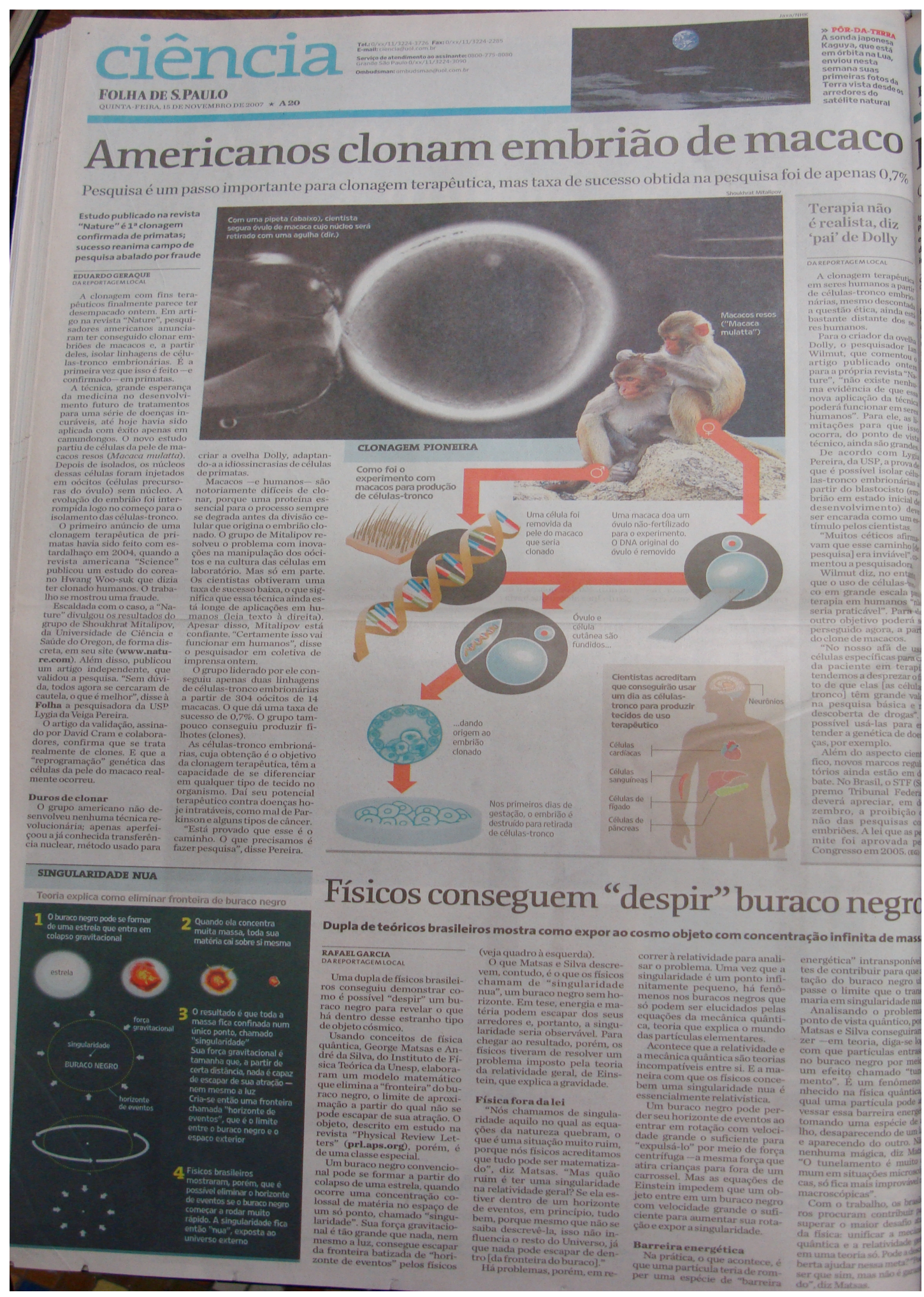


Tabela (11) Hiperestrutura da Folha de S. Paulo, 15 de novembro de 2007

\begin{tabular}{|c|c|c|}
\hline \multicolumn{3}{|r|}{ REPORTAGEM 1} \\
\hline \multirow{3}{*}{$\begin{array}{l}\text { ENUNCIADO } \\
1\end{array}$} & Título & Americanos clonam embrião de macaco \\
\hline & Título auxiliar & $\begin{array}{l}\text { Pesquisa é um passo importante para clonagem terapêutica, mas taxa de } \\
\text { sucesso obtida na pesquisa foi de apenas } 0,7 \%\end{array}$ \\
\hline & Lide & $\begin{array}{l}\text { Estudo publicado na revista "Nature" é } 1^{\circ} \text { em clonagem confirmada de } \\
\text { primatas; sucesso reanima campo de pesquisa abalado por fraude }\end{array}$ \\
\hline $\begin{array}{l}\text { ENUNCIADO } \\
2\end{array}$ & Título & Terapia não é realista, diz 'pai' de Dolly \\
\hline $\begin{array}{l}\text { ELEMENTOS } \\
\text { VERBO- } \\
\text { VISUAIS }\end{array}$ & \multicolumn{2}{|c|}{$\begin{array}{l}\text { (1) Fotografia com a legenda: "Com uma pipeta (abaixo), cientista segura óvulo de macaca } \\
\text { cujo núcleo será retirado com uma agulha (dir.)"; (2) esquema explicativo sobre o processo de } \\
\text { clonagem intitulado "Clonagem pioneira". }\end{array}$} \\
\hline \multicolumn{3}{|r|}{ REPORTAGEM 2} \\
\hline \multirow{2}{*}{$\begin{array}{l}\text { ENUNCIADO } \\
1\end{array}$} & Título & Físicos conseguem “despir” buraco negro \\
\hline & Título auxiliar & $\begin{array}{l}\text { Dupla de teóricos brasileiros mostra como expor ao cosmo objeto com } \\
\text { concentração infinita de massa }\end{array}$ \\
\hline $\begin{array}{l}\text { ELEMENTO } \\
\text { VERBO- } \\
\text { VISUAL }\end{array}$ & \multicolumn{2}{|c|}{$\begin{array}{l}\text { Esquema com explicação da teoria sobre eliminação de fronteira de buraco negro cujo título é } \\
\text { "Singularidade nua". }\end{array}$} \\
\hline \multicolumn{3}{|r|}{ DEMAIS CARACTERÍSTICAS DA PÁGINA } \\
\hline $\begin{array}{l}\text { ELEMENTO } \\
\text { VERBO- } \\
\text { VISUAL }\end{array}$ & $\begin{array}{l}\text { No alto da pági } \\
\text { elementos verb }\end{array}$ & $\begin{array}{l}\text { a há uma fotografia da sonda japonesa Kaguya e uma legenda. A união dos } \\
\text { is e visuais, nesse caso, forma uma pequena notícia. }\end{array}$ \\
\hline
\end{tabular}

De acordo com a tabela acima, em 2007, a versão impressa elabora uma página com vários elementos peritextuais e apresenta-se bastante fragmentada, apesar de veicular somente duas reportagens. A primeira é constituída de um enunciado-fonte e de outro pequeno enunciado complementar, ambos tratando sobre questões da clonagem. A segunda reportagem, do escopo da física, discorre sobre os buracos negros. Rica em sua dimensão verbo-visual, a página, espantosamente se comparada aos anos anteriores, não oferece nenhuma peça publicitária ao leitor. No alto da página, há uma pequena notícia formada 
apenas de uma fotolegenda - fotografia e uma legenda explicativa -, tendência já observada na reportagem do ano anterior, 2006.

$\mathrm{Na} \mathrm{FO}$, recuperamos somente dois dos três textos da FSP. O texto secundário que acompanha a reportagem principal da página impressa é veiculado como uma reportagem autônoma na FO, mas com referência à reportagem principal, sob forma de link eletrônico no corpo do enunciado. A segunda reportagem também pode ser acessada, mas é privada do esquema explicativo que a acompanha na FSP.

Figura (45) Folha Online, 15 de novembro de 2007 - Reportagem (1), enunciado (2) ${ }^{73}$

\title{
Clonagem terapêutica não é realista, diz "pai" de Dolly
}

\author{
da Folha de S.Paulo
}

necomendar

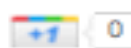

A clonagem terapêutica em seres humanos a partir de células-tronco embrionárias, mesmo descontada a questão ética, ainda está bastante distante dos seres humanos.

Para o criador da ovelha Dolly, o pesquisador Ian Wilmut, que comentou artigo publicado pela revista "Nature" a respeito da clonacem de macacos, "näo existe nenhuma evidência de que essa nova aplicaçăo da técnica poderá funcionar em seres humanos". Para ele, as limitaçöes para que isso ocorra, do ponto de vista técnico, ainda säo grandes.

De acordo com Lygia Pereira, da USP, a prova de que é possivel isolar células-tronco embrionárias a partir do blastocisto (émbriäo em estado inicial de desenvolvimento) deve ser encarada como um estímulo pelos cientistas.

"Muitos céticos afirmavam que esse caminho [de pesquisa] era inviável", comentou a pesquisadora.

Wilmut diz, no entanto, que o uso de células-tronco em grande escala para terapia em humanos "näo seria praticável". Para ele, outro objetivo poderá ser perseguido agora, a partir do clone de macacos.

"No nosso afã de usar células específicas para cada paciente em terapia, tendemos a desprezar o fato de que elas [as células-tronco] têm grande valor na pesquisa básica e na descoberta de drogas". É possivel usá-las para entender a genética de doenças, por exemplo.

Além do aspecto científico, novos marcos regulatórios ainda estão em debate. No Brasil, o STF (Supremo Tribunal Federal) deverá apreciar, em dezembro, a proibiçäo ou näo das pesquisas com embriöes. A lei que as permite foi aprovada pelo Congresso em 2005.

LEIA MAIS

- Cientistas dizem ter retirado células-tronco de embriōes clonados de macaco

Grupo decifra o genoma das 12 espécies conhecidas de drosófila

Livro explica proieto Genoma Humano em linquagem acessivel

Folha Explica o DNA e as impliceçōes da genética e biotecnoloqie

Livro discute principios e ética da clonegem

ESPECIAL

- Leia o que iá foi publicado sobre clonagem

${ }^{73}$ Disponível em: http://www1.folha.uol.com.br/folha/ciencia/ult306u345909.shtml. Acesso em: 19/05/2009. 
Figura (46) Folha Online, 15 de novembro de 2007 - Reportagem (2)

\section{5/11/2007 - 10h22 \\ Físicos brasileiros conseguem "despir" buraco negro}

RAFAEL GARCIA

da Folha de S.Paulo

mRecomendar, $7 \quad \frac{}{+1} \quad 0$

Uma dupla de físicos brasileiros conseguiu demonstrar como é possivel "despir" um buraco negro para revelar o que há dentro desse estranho tipo de objeto cósmico.

Usando conceitos de física quântica, George Matsas e André da Silva, do Instituto de Física Teórica da Unesp,

elaboraram um modelo matemático que elimina a "fronteira" do buraco negro, 0 limite de aproximação a partir do qual näo se pode escapar de sua atração.

o objeto, descrito em estudo na revista "Physical Review Letters", porém, é de uma classe especial.

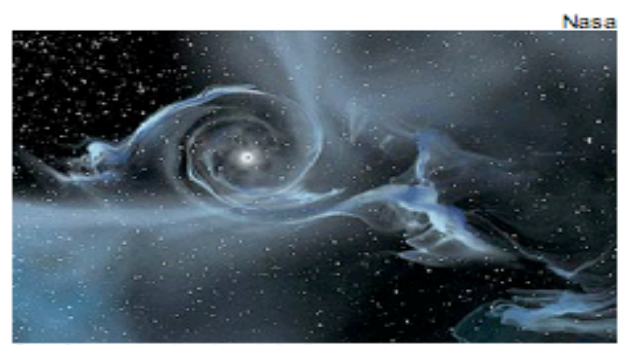

Sua força gravitacional é táo grande que nada, nem mesmo a luz, consegue escapar da fronteira batizada de "horizonte de eventos"
Um buraco negro convencional pode se formar a partir do colapso de uma estrela, quando ocorre uma

concentraçäo colossal de matéria no espaço de um só ponto, chamado "singularidade".

Sua força gravitacional é tão grande que nada, nem mesmo a luz,

consegue escapar da frontelra

consegue escapar da fronteira bat pelos isicos.

O que Matsas e Silva descrevem, contudo, é o que os físicos chamam de 'singularidade nua', um buraco negro sem horizonte. Em tese, energia e matéria podem escapar dos seus

arredores e, portanto, a singularidade seria observável.

Para chegar ao resultado, porém, os físicos tiveram de resolver um problema imposto pela teoria da relatividade geral, de Einstein, que explica a gravidade.

\footnotetext{
${ }^{74}$ Disponível em: http://www1.folha.uol.com.br/folha/ciencia/ult306u345911.shtml. Acesso em: 19/05/2009.
} 


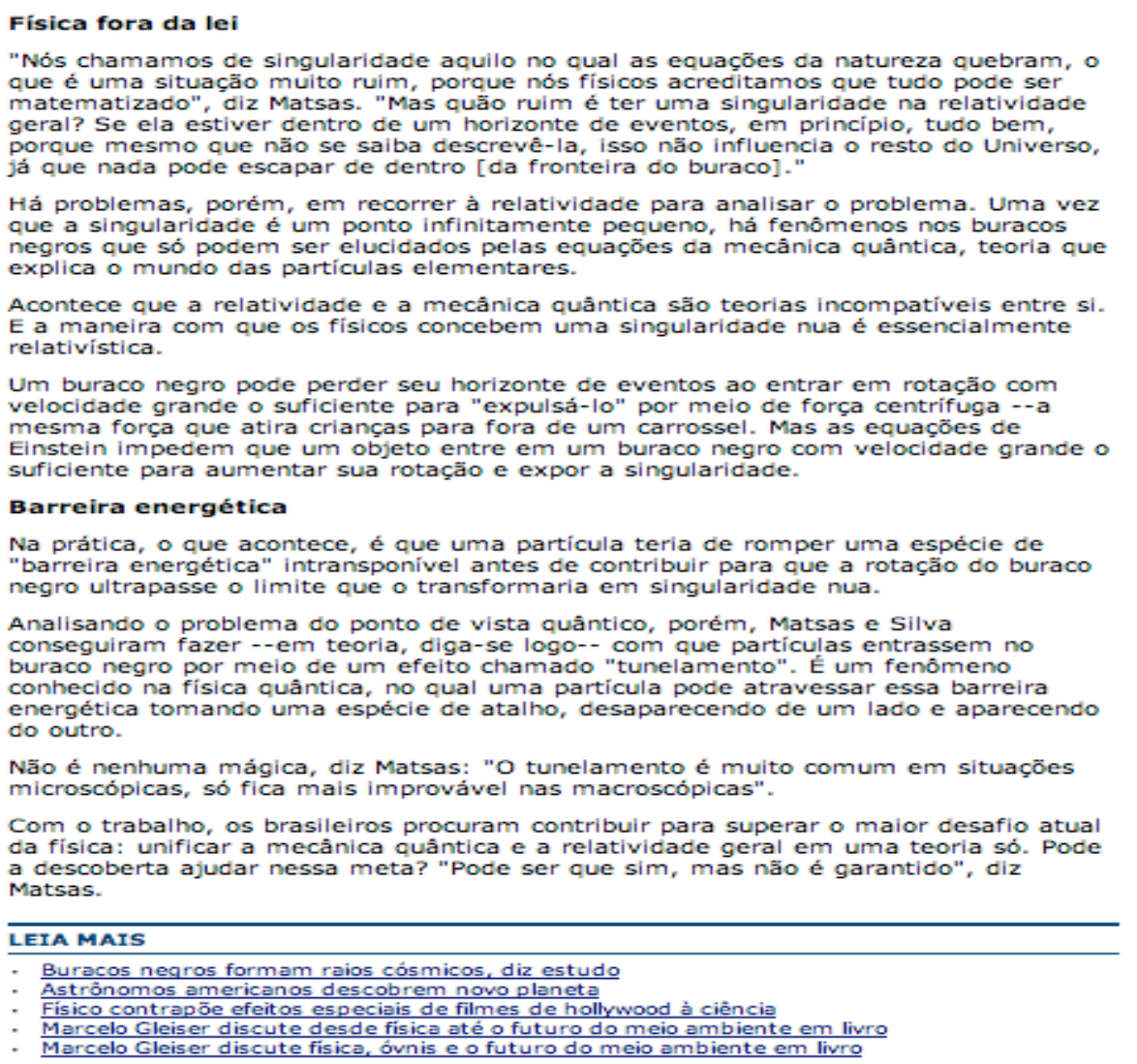

Fisica fora da lei

"Nós chamamos de singularidade aquilo no qual as equaçöes da natureza quebram, que enama porque nos fisicos acreditamos que tudo pode ser geral? Se ela estiver dentro de um horizonte de eventos, em princípio, tudo bem, porque mesmo que näo se saiba descrevê-la, isso não influencia o resto do Universo, explica o mundo das particulas elementares.

Acontece que a relatividade e a mecânica quântica säo teorias incompativeis entre si. Acom que os físicos concebem uma singularidade nua é essencialmente tivistica. velocidade grande o suficiente para expulsa-lo por meio de força centrifuga -Einstein impade atira crianças para fora de um carrossel. Mas as equaciocide grande o

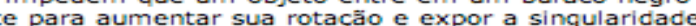

Barreira energética

Na prática, o que acontece, é que uma partícula teria de romper uma espécie de negro ultrapasse o limite que o transformaria em singularidade nua. microscópicas, só fica mais improvável nas macroscópicas". Matsas.

TA MATS

Marcelo Gleiser discute fisica ósnis e o futuro do meio ambiente em livro

Nas seções seguintes, examinaremos as relações dialógicas hipertextuais geradas pela inserção dos esquemas explicativos, infográficos, bem como planos de remissão encontrados na FO e na FSP por meio dos nós remissivos encontrados.

\subsubsection{Esquemas explicativos e infográficos: o enriquecimento do discurso de DC}

O enunciado da primeira página que destacamos no início da seção deriva do enunciado-fonte disposto na editoria "Folha Ciência" na página vinte do jornal, estabelecendo uma relação dialógica hipertextual em plano externo secundário, por pertencer a uma página externa, cuja função é resumir o conteúdo do enunciado-fonte como forma de captar o leitor. Devido ao privilegiado espaço da primeira página ser reduzido, o resumo apresentado no enunciado deve corresponder a uma chamada cujo efeito desperte no interlocutor o interesse pela leitura da reportagem

Figura (47) - Reprodução de fragmento da primeira página da FSP de 15 de novembro de 2007 


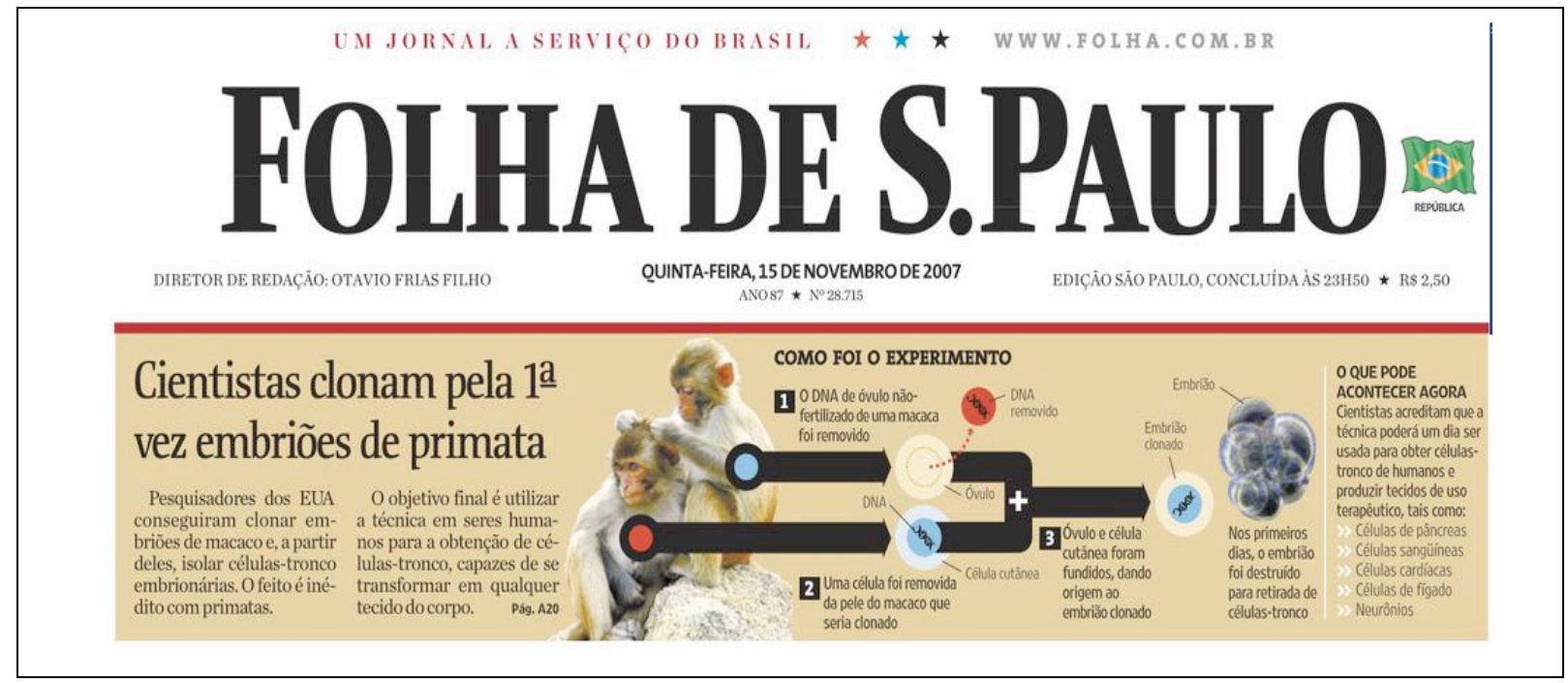

A estratégia de captação do leitor está prevista no uso do esquema explicativo que acompanha a dimensão verbal da chamada. O enunciado é composto por três partes: a primeira contém um pequeno fragmento do enunciado-fonte sob o título Cientistas clonam pela $1^{a}$ vez embriões de primata seguida de um nó remissivo à reportagem, articulado pela indicação da página - Pág. A20 - em que a descoberta científica é relatada; a segunda diz respeito ao infográfico, que também é um esquema resumido daquele apresentado no enunciado-fonte, utilizado para explicar como os cientistas chegaram à descoberta; e o último elenca as possíveis aplicações da descoberta por meio de tópicos.

No interior do enunciado há relações dialógicas entre as partes. O infográfico visa explicar a descoberta relatada e a lista final exemplifica as formas de aplicação dos resultados. A dimensão verbo-visual é complexa por conjugar a imagem dos macacos, o passo a passo enumerado da intervenção dos cientistas e pequenas imagens gráficas representando o DNA, as células e o óvulo clonado. O esquema é sucedido pela fotografia do óvulo já transformado em embrião, uma forma de comprovação do sucesso do experimento. A antecipação da reportagem pelo enunciado na primeira página centra-se de forma contundente na tríade descoberta-experimento-aplicação.

No enunciado-fonte da seção "Folha Ciência",75, o esquema explicativo é ainda mais complexo ocupando um espaço central e transversal da página. O esquema explicativo parte da imagem do óvulo no momento em que a pipeta operada pelo cientista aproxima-se para a extração do material genético. O que interliga a fotografia e o esquema é a sobreposição da imagens dos macacos utilizados no experimento, os mesmos que haviam aparecido na

75 A reportagem Americanos clonam embrião de macacos foi publicada somente na FSP. 
primeira página. O interior do esquema explicativo é marcadamente hipertextual e a remissão de uma parte do experimento a outra é feita graficamente por meio de setas. Nesse caso, a relação dialógica hipertextual é de complementação sequencial com o intuito de didatizar a metodologia científica utilizada no experimento.

Em torno do esquema explicativo, desenvolve-se a dimensão verbal da reportagem "Americanos clonam embrião de macacos". O enunciado parece contextualizar o experimento demonstrado no esquema sobre um outro experimento anterior mal sucedido e muito conhecido em todo o mundo: a clonagem da ovelha Dolly. A falta de sucesso atribuída ao caso Dolly deu-se pela morte precoce da ovelha e pela falta de resultados aplicáveis para uso comercial e em tratamentos de saúde para a sociedade. O enunciado explica que a técnica é quase a mesma, tendo passado por sensíveis alterações e exalta o fato de o alvo ter sido o macaco, além de muito parecido com o homem do ponto de vista genético, trata-se de um tipo de animal mais difícil de ser clonado. Nesse caso, a relação dialógica hipertextual de plano interno primário entre as dimensões verbal e verbo-visual do enunciado parece ser contrária àquelas observadas nos outros anos, uma vez que o verbo-visual parece constituirse como o núcleo do enunciado-fonte, sendo complementada pela dimensão verbal.

Figura (48) - Reprodução da reportagem da página da FSP de 15 de novembro de 2007, Americanos clonam embrião de macacos 


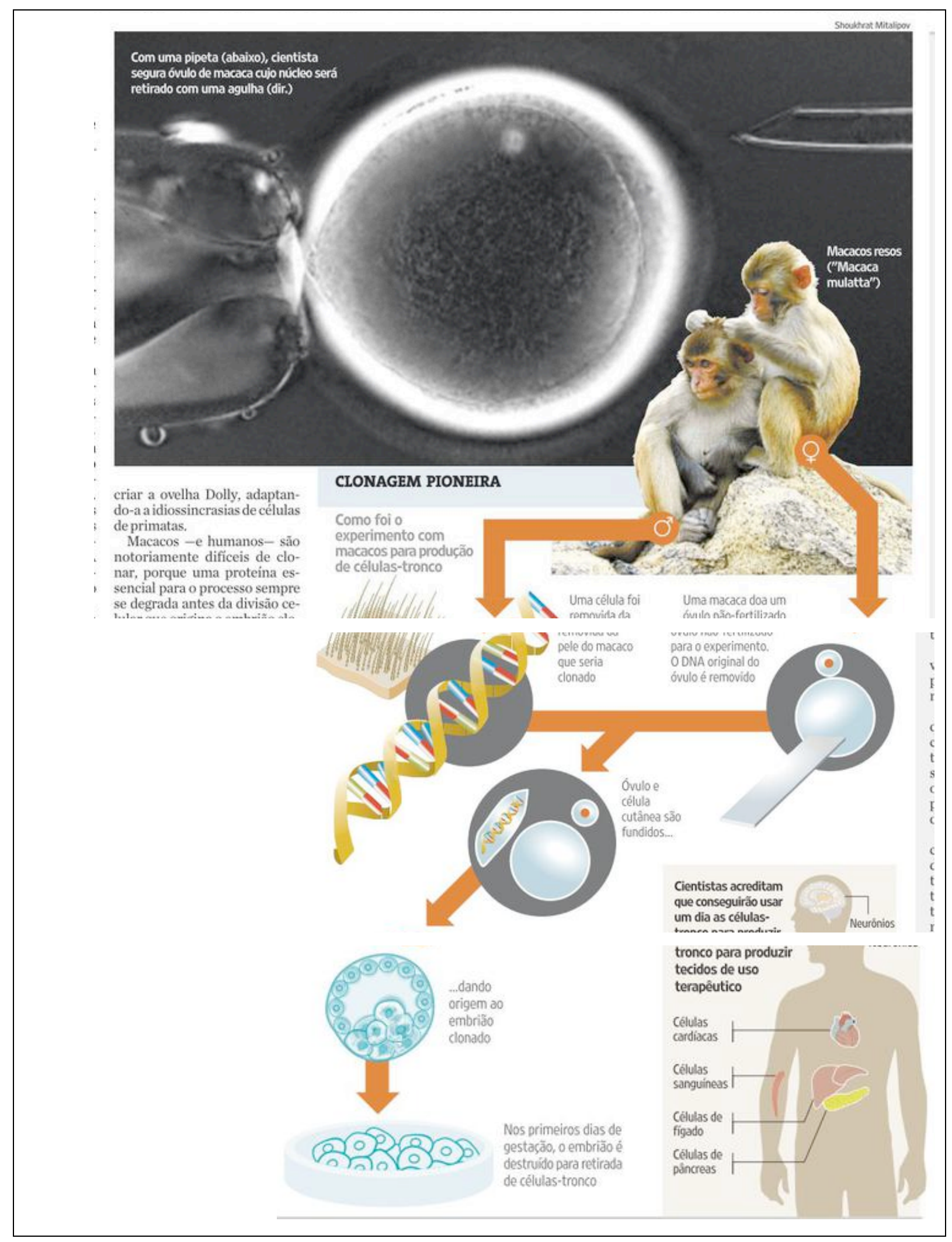

Do enunciado-fonte deriva uma pequena reportagem intitulada Clonagem terapêutica não é realista, diz 'pai' de Dolly. Em resposta à repercussão positiva em relação à pesquisa publicada na revista científica americana Nature, o jornal buscou a opinião do cientista 
responsável pela primeira clonagem na História. Na época do nascimento da ovelha Dolly, o fato científico reverberou muitas outras esferas da atividade humana, suscitando discussões, sobretudo entre jornalistas, juristas, filósofos, e pares. A função da segunda reportagem é polemizar com o objeto discursivo da primeira: o cientista Ian Wilmut toma o argumento do enunciado-fonte como alvo crítico do seu discurso, estabelecendo uma polêmica aberta.

O jornal impresso também é composto por um terceiro enunciado de dimensão verbovisual complexa, conforme apresentamos na figura abaixo:

Figura (49) - Reprodução de fragmento da reportagem da FSP de 15 de novembro de 2007, Físicos brasileiros conseguem "despir" buraco negro

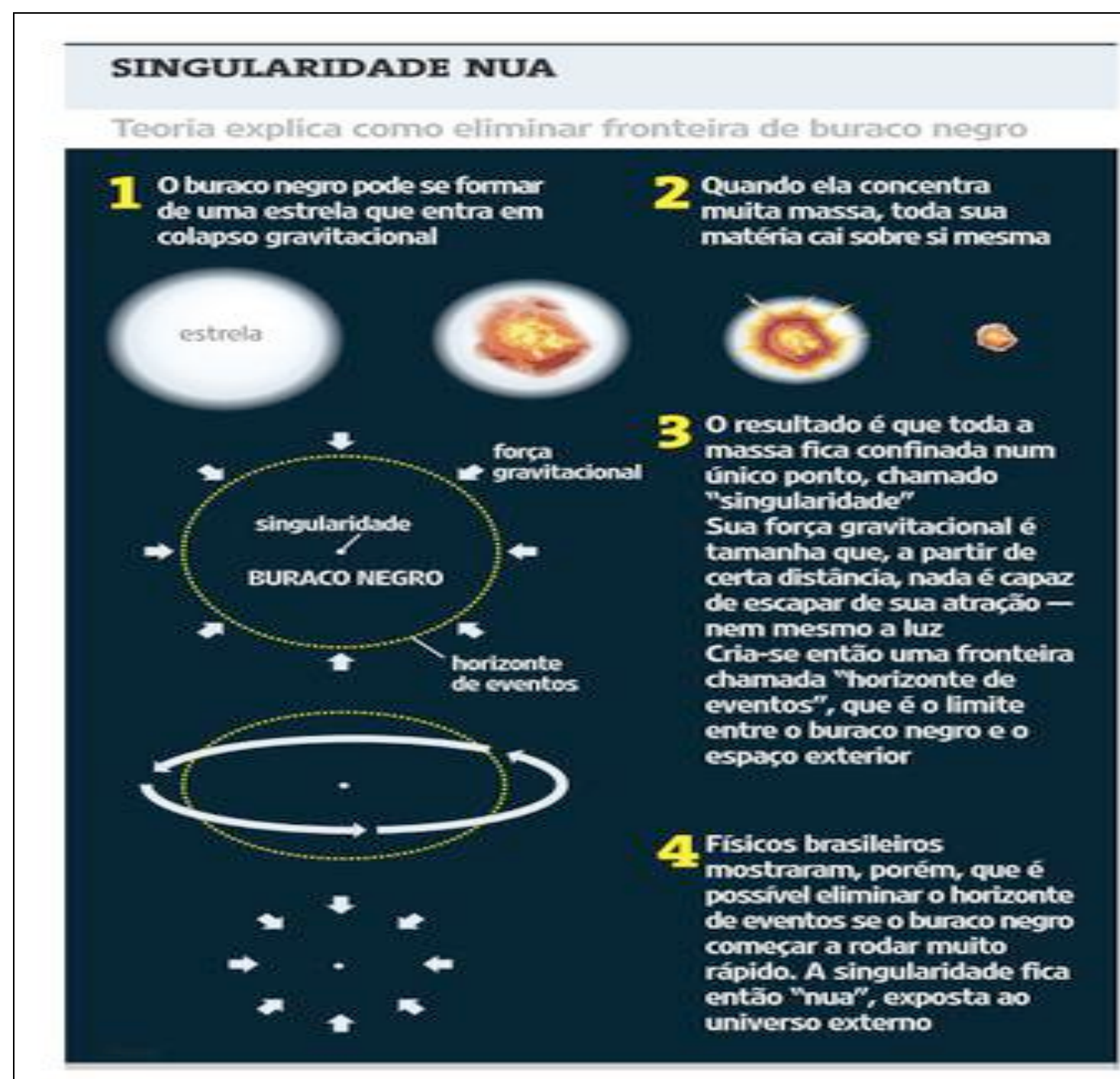

Se a primeira reportagem visa divulgar uma pesquisa da esfera científica americana, a segunda discorre sobre uma descoberta realizada por uma dupla de cientistas brasileiros no âmbito da física. A pesquisa é importante, pois rebate a relativização proposta pelo físico Albert Einstein e consegue apresentar um modelo de cálculo e apontar possíveis mudanças 
na teoria original. A reportagem difere da anterior por ser de cunho mais teórico, o que não inibe o jornalista de recorrer à implementação do infográfico para compor a dimensão verbovisual do enunciado.

O esquema visa explicar os conceitos-chave para o entendimento da reportagem, travando uma relação dialógica hipertextual que explica de forma introdutória os conceitos mobilizados pelo jornalista ao longo do enunciado. O infográfico é dotado de sequenciação tanto de elementos verbais, enumeradas de 1 a 4, quanto de elementos visuais, como as fases de conversão da estrela em buraco-negro. As setas indicam o movimento e sentido de rotação dos corpos estelares.

$\mathrm{Na} F O$, a forma lógica verbal do enunciado foi mantida, mas o esquema explicativo não foi incorporado. Ao invés, a publicação optou pela reprodução de uma imagem da Nasa, agência espacial, tal como reproduzimos abaixo.

Figura (50) - Reprodução da reportagem da FO de 15 de novembro de 2007, Físicos brasileiros conseguem "despir" buraco negro

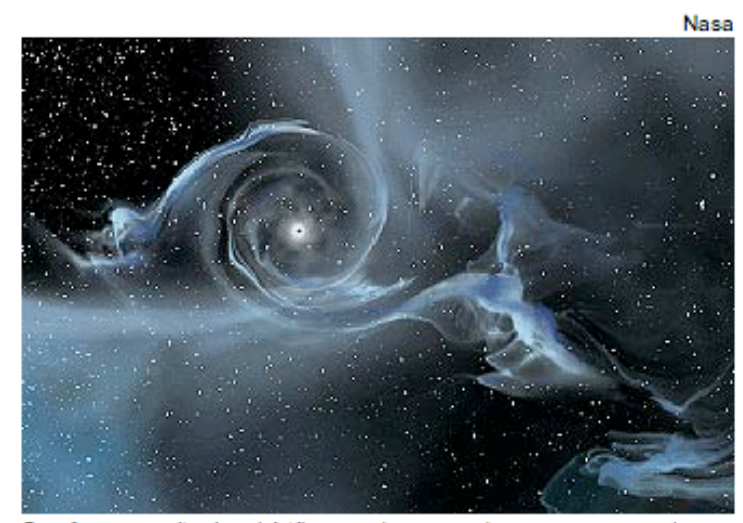

Sua força gravitacional é tão grande que nada, nem mesmo a luz, consegue escapar da fronteira batizada de "horizonte de eventos"
Um buraco negro convencional pode se formar a partir do colapso de uma estrela, quando ocorre uma concentração colossal de matéria no espaço de um só ponto, chamado "singularidade".

Sua força gravitacional é tão grande qu€ nada, nem mesmo a luz, consegue escapar da fronteira batizada de "horizonte de eventos" pelos físicos.

O que Matsas e Silva descrevem, contudo, é o que os físicos chamam de 'singularidade nua', um buraco negro

A não utilização do esquema explicativo na reportagem do meio digital é um indicativo importante sobre a prática da DC em cada publicação. Tal diferença pode ser atribuída à caracterização do interlocutor de cada reportagem. É notável que a reportagem da FSP abrange um leitor presumido mais heterogêneo, valendo-se de um maior grau de didatização na composição do enunciado. A FO, por não se aprofundar na explicação dos conceitos, tal como faz a FSP, parece ser mais informativa, como se a reportagem veiculasse, na verdade, uma notícia. Em meio digital, o leitor pode buscar rapidamente por informações complementares em sites de busca, bem como acessar outras reportagens sugeridas ao final 
do enunciado, por meio de nós remissivos eletrônicos, como examinaremos na seção seguinte.

\subsubsection{Planos de remissão e relações dialógicas hipertextuais: uma estratégia de posicionamento ideológico}

Como vimos anteriormente, a inserção de esquemas explicativos não é produtiva na FO até o momento. Contudo, a remissão hipertextual por meio de nós eletrônicos é muito produtiva e crescente nesse meio, se compararmos aos anos anteriores. Se nos anos iniciais os links eram situados somente em espações periféricos em relação à dimensão verbal do enunciado, agora eles passam a permear o interior da reportagem como verificamos no exemplo abaixo:

Figura (51) - Reprodução de fragmento da reportagem da FO de 15 de novembro de 2007, Físicos brasileiros conseguem "despir” buraco negro

\section{Físicos brasileiros conseguem "despir" buraco negro}

RAFAEL GARCIA

da Folha de S.Paulo

Recomendar 8

Uma dupla de físicos brasileiros conseguiu demonstrar como é possível "despir" um buraco negro para revelar o que há dentro desse estranho tipo de objeto cósmico.

Usando conceitos de física quântica, George Matsas e André da Silva, do Instituto de Física Teórica da Unesp, elaboraram um modelo matemático que elimina a "fronteira" do buraco negro, o limite de aproximação a partir do qual não se pode escapar de sua atração.

O objeto, descrito em estudo na revista "Physical Review Letters", porém, é de uma classe especial.

Quando o nó eletrônico aparece no interior do enunciado, geralmente há uma remissão a um enunciado externo ao site da FO. No caso acima, o link Physical Review Letters remete o leitor ao site da revista especializada que relata o estudo diretamente da esfera científica. Como relação dialógica hipertextual, apontamos a possibilidade de 
aprofundamento, ou mesmo de legitimidade da fonte científica da pesquisa. Abaixo, reportamos os outros tipos de ocorrência de nós eletrônicos, cujas funções conhecemos nas edições anteriores: o "Leia Mais" situa o enunciado na cronologia com eventos anteriores ou indica uma complementação por meio da adição de novas informações; e o "Especial" sempre leva à segunda opção, adição do novo.

Figura (52) - Reprodução de fragmento da reportagem da FO de 15 de novembro de 2007, Físicos brasileiros conseguem “despir” buraco negro

LEIA MAIS

- Buracos negros formam raios cósmicos, diz estudo

- Astrônomos americanos descobrem novo planeta

- Físico contrapõe efeitos especiais de filmes de hollywood à ciência

- Marcelo Gleiser discute desde física até o futuro do meio ambiente em livro

- Marcelo Gleiser discute fisica, óvnis e o futuro do meio ambiente em livro

ESPECIAL

- Leia o que já foi publicado sobre buraco negro

A FO não recupera a reportagem principal da FSP na data, mas publica o segundo enunciado: Clonagem terapêutica não é realista, diz "pai" de Dolly. Na FSP a relação dialógica do enunciado é estritamente delineada na sua junção com o enunciado-fonte, Americanos clonam embrião de macacos. Considerando que o enunciado derivado trava uma relação dialógica de polêmica aberta em relação ao primeiro, como é dada essa relação na FO se não há o enunciado-fonte? Para responder tal questão, temos que observar o fragmento seguinte:

Figura (53) - Reprodução de fragmento da reportagem da FO de 15 de novembro de 2007, Clonagem terapêutica não é realista, diz "pai" de Dolly 


\section{(a) \\ Clonagem terapêutica não é realista, diz "pai" de Dolly \\ da Folha de S.Paulo}

f Recomendar $\quad 0 \quad Q + 1 \longdiv { 0 }$

A clonagem terapêutica em seres humanos a partir de células-tronco embrionárias, mesmo descontada a questão ética, ainda está bastante distante dos seres humanos.

Para o criador da ovelha Dolly, o pesquisador Ian Wilmut, que comentou artigo publicado pela revista "Nature" a respeito da clonagem de macacos, "não existe nenhuma evidência de que essa nova aplicação da técnica poderá funcionar em seres humanos". Para ele, as limitações para que isso ocorra, do ponto de vista técnico, ainda são grandes.

De acordo com Lygia Pereira, da USP, a prova de que é possível isolar células-tronco embrionárias a partir do blastocisto (embrião em estado inicial de desenvolvimento) deve ser encarada como um estímulo pelos cientistas.

A partir do exemplo, percebemos que há a inserção de um fragmento, que não consta no enunciado da FSP, sob forma de link eletrônico: a respeito da clonagem de macacos. Trata-se de uma importante ancoragem prevista na relação dialógica entre o enunciado-fonte e a reportagem sobre o estudo da revista Nature publicado anteriormente pela própria FO, uma vez que a polêmica só pode ser instaurada se o enunciado anterior pode ser resgatado. $\mathrm{O}$ dado interessante é que a reportagem recuperada difere daquela na FSP. Nesse caso, trata-se da reportagem que foi adaptada de uma outra publicada em uma agência de notícia francesa, France Presse de Paris. Esse é um indício de que a FO possui mais autonomia em sua editoria de ciência, o que poderá ser confirmado nas considerações finais da tese, ao observarmos o quadro geral das relações dialógicas hipertextuais encontradas na pesquisa.

A reportagem ainda repete os mesmos planos de remissão e relações dialógicas hipertextuais identificadas no exemplo acima, no que tange aos nós remissivos eletrônicos periféricos, ou seja, situados na parte final da página. 
Figura (54) - Reprodução de fragmento da reportagem da FO de 15 de novembro de 2007, Clonagem terapêutica não é realista, diz "pai”" de Dolly

"No nosso afã de usar células específicas para cada paciente em terapia, tendemos a desprezar o fato de que elas [as células-tronco] têm grande valor na pesquisa básica e na descoberta de drogas". É possível usá-las para entender a genética de doenças, por exemplo.

Além do aspecto científico, novos marcos regulatórios ainda estão em debate. No Brasil, o STF (Supremo Tribunal Federal) deverá apreciar, em dezembro, a proibição ou não das pesquisas com embriões. A lei que as permite foi aprovada pelo Congresso em 2005.

\section{LEIA MAIS}

- Cientistas dizem ter retirado células-tronco de embriões clonados de macaco

- Grupo decifra o genoma das 12 espécies conhecidas de drosófila

- Livro explica projeto Genoma Humano em linquagem acessível

- Folha Explica o DNA e as implicações da genética e biotecnologia

- Livro discute princípios e ética da clonagem

\section{ESPECIAL}

- Leia o que já foi publicado sobre clonagem

Não somente na FO há inserções de nós remissivos no interior do enunciado. A FSP também veicula a representação de um link ( $\underline{\text { www.nature.com) }}$ remetendo o enunciado ao site da revista Nature, como forma de legitimação do estudo situando-o na esfera científica, muito mais do que um possível aprofundamento do leitor, que não dispõe da tecnologia de remissão direta ao endereço, como seria possível no meio digital.

Figura (55) - Reprodução de fragmento da reportagem da FSP de 15 de novembro de 2007, Americanos clonam embrião de macaco

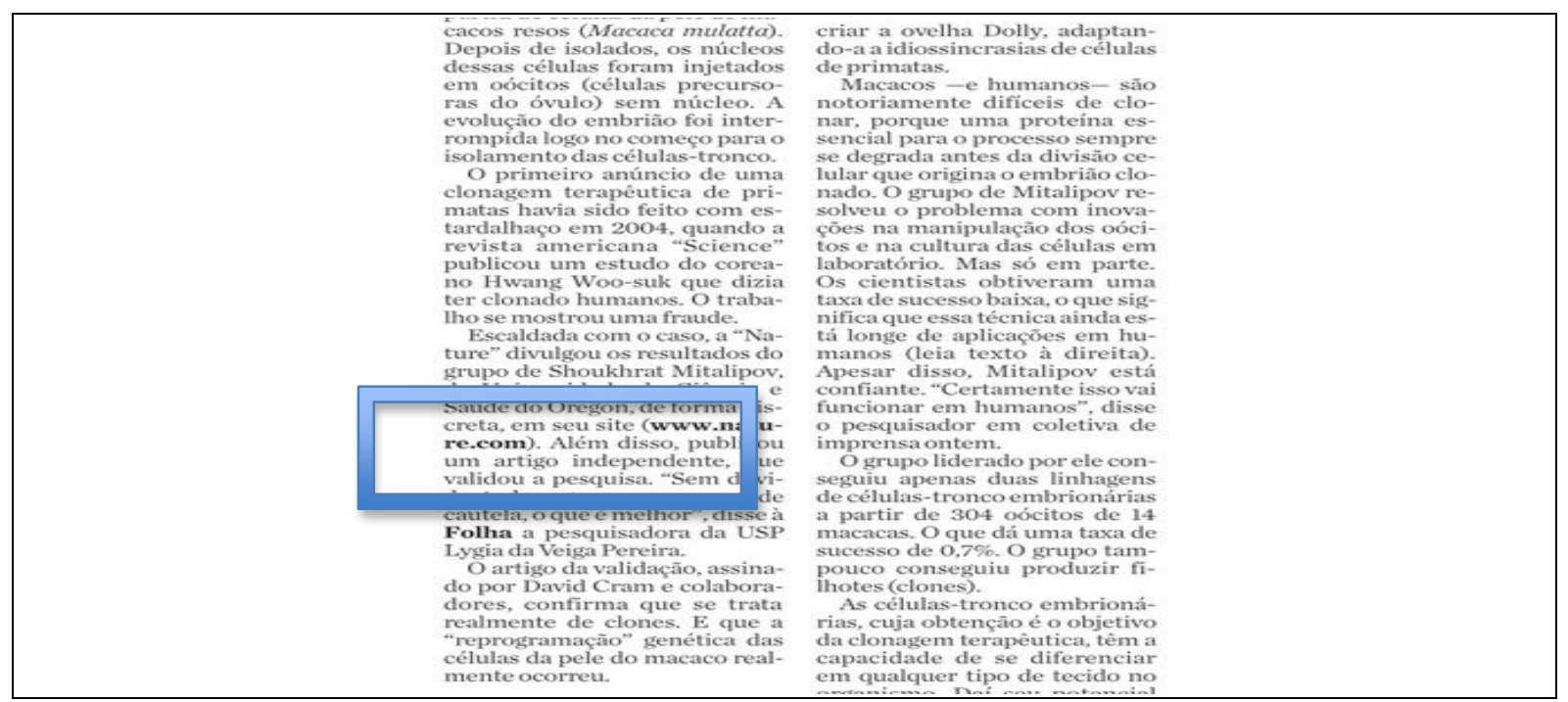




\subsubsection{Síntese}

Os temas da esfera científica estão mais presentes nas reportagens selecionadas em 2007, em contraposição aos demais anos. Se anteriormente, o discurso político atravessava de forma aberta o discurso de DC, podemos considerar que houve um deslocamento importante. Observamos uma página cujas reportagens estão voltadas para assuntos da esfera científica, cujos experimentos são detalhados e sua aplicabilidade é ressaltada, mesmo no plano teórico, como no caso do isolamento dos buracos negros, - com o objetivo principal de promover as pesquisas ou pesquisadores brasileiros.

Obviamente, sabemos que os enunciados que circulam em um jornal com a FSP são selecionados de acordo com as coerções da esfera jornalística que, como descrevemos no capítulo anterior, deve atender a uma série de procedimentos editoriais, sobretudo no que tange à escolha das pautas.

Não podemos, contudo, apostar no esvaziamento total das questões políticas, mesmo porque, a apresentação das pesquisas corresponde a uma resposta à sociedade no tocante aos investimentos do governo feitos a partir do recolhimento de impostos da sociedade da qual o leitor faz parte. A primeira reportagem, apesar de se referir a um procedimento realizado nos EUA, traz, na reportagem secundária, a opinião de uma especialista brasileira em genética, a Dra. Lygia Pereira, da Universidade de São Paulo. A segunda visa à apresentação de uma pesquisa desenvolvida por dois brasileiros em uma universidade estadual do estado de São Paulo, a UNESP, cujo objetivo principal é de "contribuir para superar o maior desafio da física: unificar a mecânica quântica e a relatividade em uma teoria só".

Do ano de 2007, depreendemos o visível desprendimento entre as editorias de ambos os jornais, cuja orientação volta-se a caminhos diferentes, sobretudo no que tange à hipertextualidade: na FSP os elementos verbais e verbo-visuais congregam-se a fim de apresentar a descoberta científica, explicar seus procedimentos e indicar a sua aplicabilidade. A dimensão verbo-visual chega a saltar no plano bidimensional da página, tornando-se central para o desenvolvimento do enunciado. A FO assume um caráter mais superficial no modo de veicular a informação e o gênero reportagem parece apresentar uma característica mais noticiosa dos fatos científicos. 


\subsection{Reportagens do ano 2008: curiosidade versus cientificidade}

Os enunciados de cada ano mostraram-nos uma significativa mudança no conteúdo temático das reportagens tanto da FO quanto da FSP. Em um intervalo menor de 10 anos, constatamos o enfraquecimento da presença da esfera política que imperava nos anos iniciais de análise, a consolidação de aspectos da esfera científica e do próprio discurso de divulgação científica, indícios de autonomia editorial da FO, e a diferenciação nos modos de produção de sentido em cada meio, cujas relações dialógicas hipertextuais especializaram-se diferentemente: a FO a partir dos nós remissivos eletrônicos e a FSP por meio de esquemas explicativos previstos na dimensão verbo-visual da página impressa.

Para quem verificou o debate político e o jogo de polêmicas sobre o discurso presidencial em um primeiro momento, não facilmente poderia supor que ao final da pesquisa nos depararíamos com uma reportagem sobre a rota de fuga das baratas, em 2008. $\mathrm{O}$ deslocamento de temas políticos foi completamente apagado, e, além de ter a DC com espaço consolidado, o enunciado parece nos reportar à curiosidade. É interessante observar que a como a reportagem é introduzida por uma expressão proveniente da esfera da ideologia do cotidiano que, ao mesmo tempo, sugere ao leitor, de forma imperativa, aplicabilidade do estudo: "Prepare seu chinelo".

O interlocutor é chamado a participar do evento, sendo situado como uma personagem do enunciado: "Você acende a luz da cozinha e topa com ela: grande, marrom, cascuda. Uma barata de respeitável tamanho". Pela primeira vez, o tom mais informal invade a página da editoria, aproximando o leitor da situação comunicativa. No ano de 2008, as reportagens comuns da FSP e da FO trataram, prioritariamente, de assuntos relacionados à genética e à cosmologia. Observamos que as reportagens veiculadas na FO ao longo do mês de novembro deste ano abrangem uma variedade de assuntos, mas que, na FSP, os enunciados selecionados discorrem majoritariamente sobre essas duas áreas da esfera científica.

Já a primeira reportagem segue a linha editorial que observamos nos anos anteriores. Geralmente, as reportagens da FSP apresentam uma relação com algum acontecimento de relevância ao nosso país, como uma descoberta ou inovação em algum campo da ciência feita por um brasileiro. Nesse ano, o que motivou a presença de reportagens relacionadas ao espaço foi o anúncio de um projeto de lançamento de satélites brasileiros em órbita. Ao mesmo tempo, havia inúmeras pesquisas voltadas ao estudo do genoma humano também compondo o cenário científico-acadêmico brasileiro. As reportagens foram escritas, 
respectivamente, por Rafael Garcia, já apresentado anteriormente, e Ricardo Bonalume Neto, repórter especial da FSP. O jornalista é especializado em ciência, tecnologia, meio-ambiente e história militar e já havia trabalhado como redator e editor-assistente das seções sobre Educação e Ciência.

A partir da observação da página impressa e sob o ponto de vista da hiperestrutura, a organização dos enunciados da reportagem segue a mesma composição daquela encontrada em 2006, isto é, os títulos auxiliares não possuem mais a função de delimitar as reportagens que passam a ser delineadas por meio do tamanho da fonte de seus próprios títulos. A segunda reportagem, que trata da rota de fuga das baratas, possui um caráter de curiosidade e uma entonação valorativa que parece ser relativa a um público mais jovem, tal como o anúncio publicitário disposto ao final da página.

Iniciamos a descrição das reportagens que formam o corpus do ano de 2008 com a reprodução da imagem da página do jornal impresso, na figura (55), seguida da tabela que detalha a hiperestrutura da FSP nessa data: 


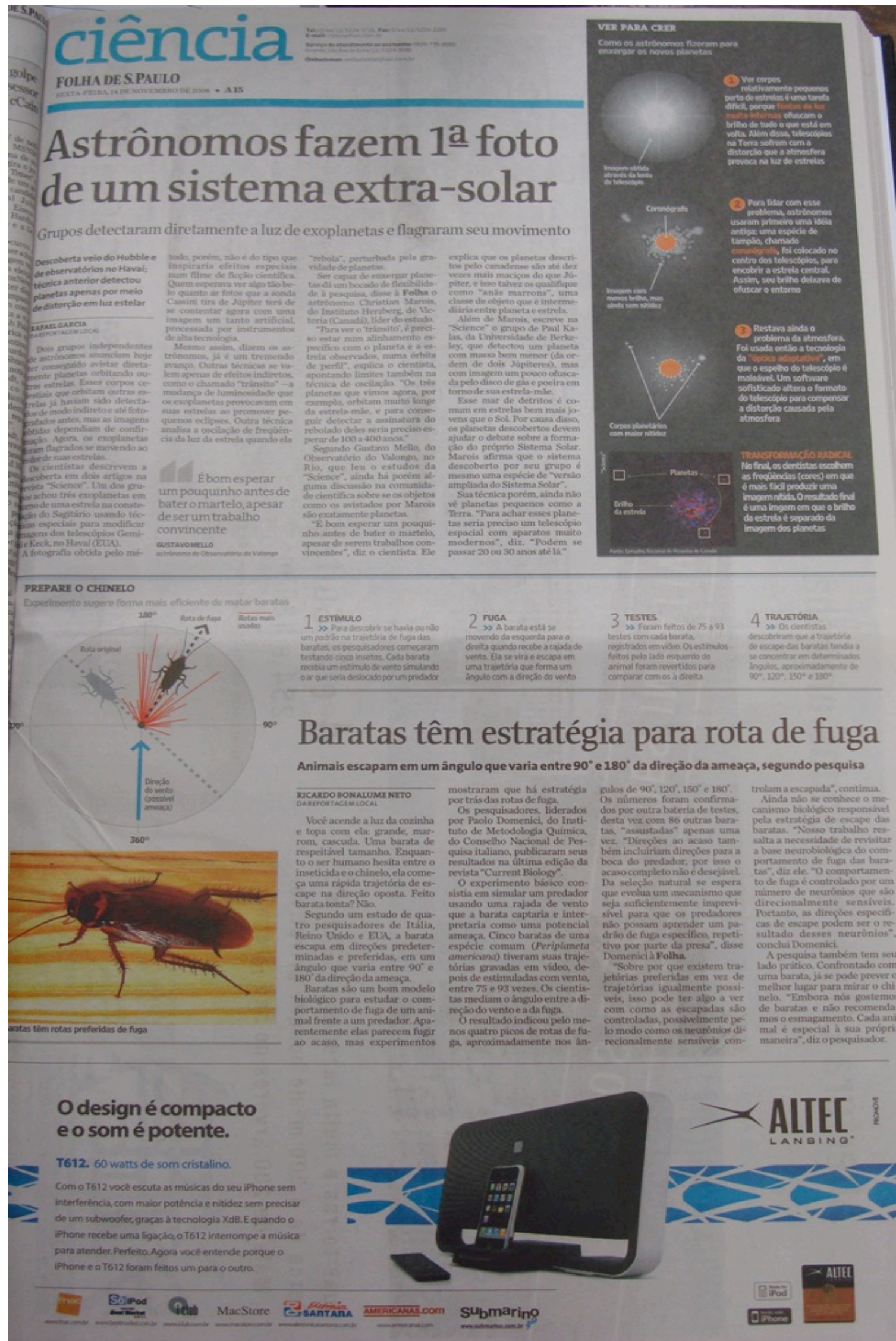


Tabela (12) Hiperestrutura da Folha de S. Paulo, 14 de novembro de 2008

\begin{tabular}{|c|c|c|}
\hline & & REPORTAGEM 1 \\
\hline \multirow{4}{*}{$\begin{array}{l}\text { ENUNCIADO } \\
\qquad 1\end{array}$} & Título & Astrônomos fazem $1^{\text {a }}$ foto de um sistema extra-solar \\
\hline & Título auxiliar & $\begin{array}{l}\text { Grupos detectaram diretamente a luz de exoplanetas e flagraram seu } \\
\text { movimento }\end{array}$ \\
\hline & Lide & $\begin{array}{l}\text { Descoberta veio do Hubble e observatórios no Havaí; técnica anterior } \\
\text { detectou planetas apenas por meio de distorção em luz estelar }\end{array}$ \\
\hline & Olho & $\begin{array}{l}\text { "É bom esperar um pouquinho antes de bater o martelo, apesar de ser um } \\
\text { trabalho convincente", Gustavo Mello, astrônomo do Observatório do } \\
\text { Valongo }\end{array}$ \\
\hline $\begin{array}{l}\text { ELEMENTO } \\
\text { VERBO } \\
\text { VISUAL }\end{array}$ & \multicolumn{2}{|c|}{$\begin{array}{l}\text { Esquema com três itens e mais uma legenda que explica o passo a passo da descoberta de } \\
\text { novos planetas pelos cientistas, intitulado "Ver para crer". }\end{array}$} \\
\hline \multicolumn{3}{|r|}{ REPORTAGEM 2} \\
\hline \multirow{2}{*}{$\begin{array}{l}\text { ENUNCIADO } \\
1\end{array}$} & Título & Baratas têm estratégia para rota de fuga \\
\hline & Título auxiliar & $\begin{array}{l}\text { Animais escapam em um ângulo que varia entre } 90^{\circ} \text { e } 180^{\circ} \text { da direção da } \\
\text { ameaça, segundo pesquisa }\end{array}$ \\
\hline $\begin{array}{l}\text { ELEMENTO } \\
\text { VERBO } \\
\text { VISUAL }\end{array}$ & \multicolumn{2}{|c|}{$\begin{array}{l}\text { Esquema formado de } 4 \text { itens com ilustrações e informações sobre o inseto, intitulado "Prepare } \\
\text { o chinelo". }\end{array}$} \\
\hline \multicolumn{3}{|r|}{ ENUNCIADOS DE PUBLICIDADE } \\
\hline \multirow{2}{*}{ PEÇA 1} & Produto & Aparelho de som da empresa Altec Lansing. \\
\hline & $\begin{array}{l}\text { Chamada } \\
\text { principal }\end{array}$ & O design é compacto e o som é potente. \\
\hline
\end{tabular}

No que tange ao uso dos nós remissivos, verificamos que a FO emprega um nó eletrônico para vincular o nome dos autores do estudo, mas que esta relação hipertextual não está marcada na FSP. Ainda na FO, o termo 'Folha' aparece em negrito, assim como a ocorrência que detectamos em 2006, remetendo o leitor do jornal digital à fonte do enunciado, produzido para ser publicado na FSP. Abaixo, reproduzimos os enunciados das reportagens da FO, publicados em novembro de 2008: 
Figura (57) Folha Online, 14 de novembro de 2008 - Reportagem (1) ${ }^{76}$

\begin{tabular}{|c|c|c|c|c|}
\hline AA Maior / Menor & 国 Enviar por e-mail & [ㅂ. Comunicar erros & 国 Imprimir & Compartilite $E\left[\begin{array}{l}t \\
\end{array}\right.$ \\
\hline
\end{tabular}

\section{Astrônomos fazem $1^{\text {a }}$ foto de um sistema extra-solar}

RAFAEL GARCIA

da Folha de S.Paulo

Iu. Recomendar 1 Seja o primeiro de seus amigos a recomendar isso.

Dois grupos independentes de astrônomos anunciam hoje te conseguido avistar diretamente planetas orbitando outras estrelas. Esses corpos celestiais que orbitam outras estrelas já haviam sido detectados de modo indireto e até fotografados antes, mas as imagens obtidas dependiam de confirmação.

Agora, os exoplanetas foram flagrados se movendo ao redor de suas estrelas.

Os cientistas descrevem a descoberta em dois artigos na revista "Science". Um dos usando técnicas especiais para modificar imagens dos telescópios Gemini e Keck, no Havai (EUA).

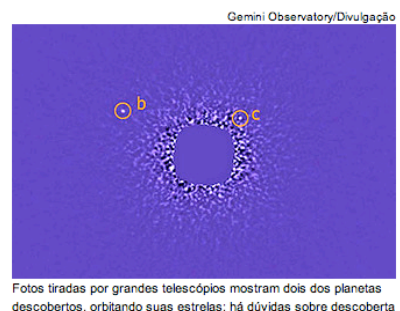

A fotografia obtida pelo método, porém, não é do tipo que inspiraria efeitos

especiais num ailme de ficção científica.

Quem esperava ver algo táo belo quanto

Uúpiter teŕ a se se contentar agora com

uma imagem um tanto artificial,

processada por instrumentos de alta

tecnologia.

Mesmo assim, dizem os astrônomos, já é um tremendo avanço. Outras técnicas se valem apenas de efeitos indiretos, descobertos, orbitando suas estrelas: há dúvidas sobre descobern de luminosidade que os exoplanetas
provocavam em suas estrelas ao

promover pequenos eclipses.

Outra técnica analisa a oscilação de frequência da luz da estrela quando ela "rebola", perturbada pela gravidade de planetas.

Ser capaz de enxergar planetas dá um bocado de flexibilidade à pesquisa, disse à Folha 0 astrônomo Christian Marois, do Instituto Herzberg, de Victoria (Canadá), líder do estudo.

"Para ver o "trânsito", é preciso estar num alinhamento específico com o planeta e estrela observados, numa órbita de perfil", explica o cientista, apontando limites também na técnica de oscilação. "Os três planetas que vimos agora, por exemplo, orbitam muito onge da estrela-máe, e para conseguir detectar a ass

Segundo Gustavo Mello, do Observatório do Valongo, no Rio, que leu o estudos da "Science", ainda há porém alguma discussão na comunidade científica sobre se os objetos como

"É bom esperar um pouquinho antes de bater o martelo, apesar de serem trabalhos convincentes", diz o cientista. Ele explica que os planetas descritos pelo canadense são até dez vezes mais maciços do que Júpiter, e isso talvez os qualifique como "anãs marrons", uma classe de objeto que é intermediária entre planeta e estrela.

Além de Marois, escreve na "Science" 。 grupo de Paul Kalas, da Universidade de mase be que dou Jupíteres), mas com imagem um pouco ofuscada pelo disco de gás e poeira em torno de sua estrela-mãe.

Esse mar de detritos é comum em estrelas bem mais jovens que o Sol. Por causa disso, os planetas descobertos devem ajudar o debate sobre a formação que o sistema descoberto por seu arupo mesmo uma espécie de "vers̃o ampliada do Sistema Solar".

Sua técnica, porém, ainda não vê espacial com aparatos muito modernos", diz. "Podem se passar 20 ou 30 anos até lá."
C. Acompanhe a Folha.com no Twitter te

as últimas que você não leu

1. EUA têm primeira grande Arcimboldo

2. Destaques da TV desta quarta-feira

3. PMs confundem colega com

4. Televisa e Lionsgate se unem para o

5. A R\$ 9,90, "Homem Chavão" alerta para clichês na hora da morte de

6. Justiça argentina condena padre

pedóflio a 15 anos de prisáo

7. Em Altamira, Serra diz que sabe bater pênalt'

8. Figueirense perde para o América-
MG e corre risco de sair da ponta da Série B

9. Bombeiros controlam incêndio na zona sul de SP; favela da zona leste

10. TSE nega direito de resposta de Dilma em programa de Serra po

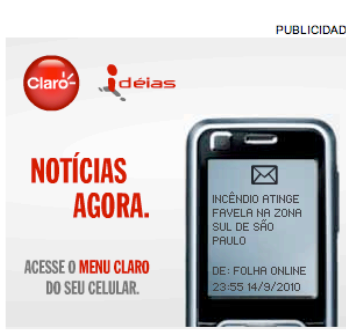

+ lidas

1. Exame de sangue pode detectar Alzheimer, diz estudo

2. Concurso para professor universitário ignora pós 3. Cientista alerta sobre superbactéria
resistente a quase todos antibióticos 4. Graduação não tradicional complica 5. Meteorito que caiu na França tem
estilhaços de supernova

+ comentadas

1. Felicidade custa $\mathrm{R} \$ 11$ mil por mês, aponta estudo

2. Foguete nacional só deve decola em 2015

+ enviadas

1. Exame de sangue pode detectar Alzheimer, diz estudo

2. Felicidade custa $\mathrm{R} \$ 11$ mil por mês, aponta estudo
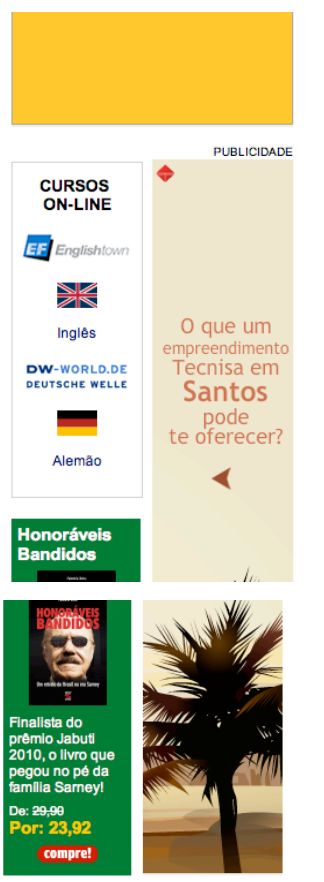

folhashop

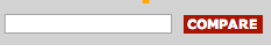

3 Auto Rádio

Diversos modelos a partir

Kit de Maquiagem Diversos tipos a partir de Canon ........

(O) sem juros

Celular Messenger
Diversas cores a partir de
$\mathrm{Rs} 324$

Mochila para Notebook Diversos modelos a partir

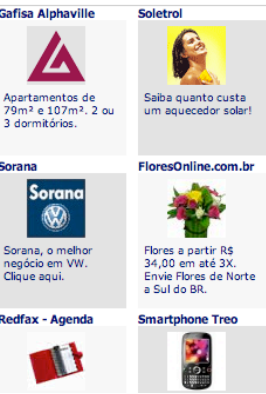

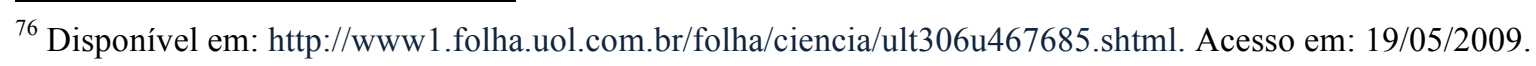


LEIA MAIS

- Cientistas vêem aurora "sinqular" em Saturno

- Partícula "fantasma" surge em colisão em acelerador nos EUA

Nasa cancela nova missão de reparo do telescópio Hubble

Hubble volta a funcionar e divulga imagem nova do espaca

LIVRARIA

- Livro desvenda MARTE, explica os mitos do planeta e revela curiosidades

- Entenda os TEMAS ATUAIS da ciência em livro de Marcelo Gleiser

ESPECIAL

- Leia o que iá foi publicado sobre espaço
LIVRARIA DA FOLHA

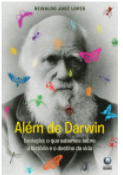

ALÉM DE DARWIN

De: 22.00

COMPRAR

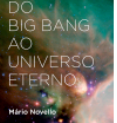

DO BIG BANG AO
UNIVERSO ETERNO

Mário Novello

De: 28.00

Por: 23,00

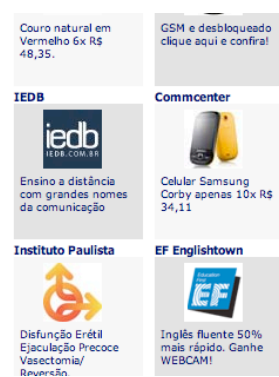

Figura (58) Folha Online, 14 de novembro de 2008 - Reportagem (2)

\section{ciência}

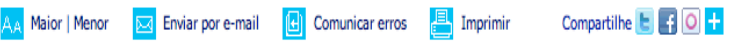

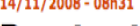 \\ Baratas têm estratégia para rota de fuga}

RICARDO BONALUME NETO

da Folha de S.Paulo

¿3 Recomendar $\mathbf{A}$ Seja o primeiro de seus amigos a recomendar isso.

Você acende a luz da cozinha e topa com ela: grande, marrom, cascuda. Uma barata de respeitável tamanho. Enquanto o ser humano hesita entre 0 inseticida e o chinelo, ela começa uma rápida trajetória de escape na direção oposta. Feito barata tonta? Não

Segundo um estudo de quatro pesquisadores de Itália, Reino Unido e EUA, a barata escapa em direções predeterminadas e preferidas, em um ângulo que varia entre $90^{\circ} \mathrm{e}$ $180^{\circ}$ da direção da ameaça.

Baratas são um bom modelo biológico para estudar o comportamento de fuga de um animal frente a um predador. Aparentemente elas parecem fugir ao acaso, mas experimentos mostraram que há estratégia por trás das rotas de fuga.

Os pesquisadores, liderados por Paolo Domenici, do Instituto de Metodologia Química, do Conselho Nacional de Pesquisa italiano, publicaram seus resultados na última edição da revista "Current Biology".
Acompanhe a Folha.com no Twitter $t$

as últimas que vocênão leu

1. EUA têm primeira grande

retrospectiva do pintor italiano Arcimboldo

2. Destaques da TV desta quarta-feira

3. PMs confundem colega com assaltante e matam policial no Rio

4. Televisa e Lionsgate se unem para 0 público latino dos EUA

5. A R\$ 9,90 , "Homem Chavão" alerta para clichês na hora da morte de famosos

6. Justiça argentina condena padre pedófilo a 15 anos de prisão

7. Em Altamira, Serra diz que sabe bater pênalti

8. Figueirense perde para o AméricaMG e corre risco de sair da ponta da Série $B$

9. Bombeiros controlam incêndio zona sul de SP; favela da zona leste $h$ atimninds
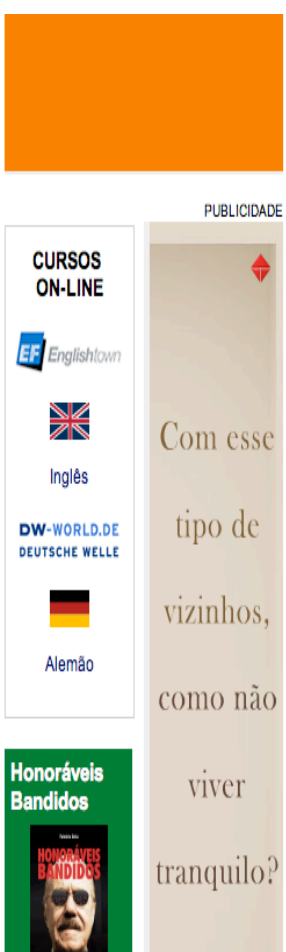

\footnotetext{
${ }^{77}$ Disponível em: http://www1.folha.uol.com.br/folha/ciencia/ult306u467637.shtml. Acesso em: 19/05/2009.
} 
0 experimento básico consistia em simular um predador usando uma rajada de vento que a barata captaria e interpretaria como uma potencial ameaça. Cinco baratas de uma espécie comum (Periplaneta americana) tiveram suas trajetórias gravadas em vídeo, depois de estimuladas com vento, entre 75 e 93 vezes. Os cientistas mediam o ângulo entre a direção do vento e a da fuga.

0 resultado indicou pelo menos quatro picos de rotas de fuga, aproximadamente nos ângulos de 90,120, 150 e 180. Os números foram confirmados por outra bateria de testes, desta vez com 86 outras baratas, "assustadas" apenas uma vez.

"Direções ao acaso também incluiriam direções para a boca do predador, por isso o acaso completo não é desejável. Da seleção natural se espera que evolua um mecanismo que seja suficientemente imprevisivel para que os predadores não possam aprender um padrão de fuga específico, repetitivo por parte da presa", disse Domenici à Folha.

"Sobre por que existem trajetórias preferidas em vez de trajetórias igualmente possiveis, isso pode ter algo a ver com como as escapadas são controladas, possivelmente pelo modo como os neurônios direcionalmente sensíveis controlam a escapada", continua.

Ainda não se conhece o mecanismo biológico responsável pela estratégia de escape das baratas. "Nosso trabalho ressalta a necessidade de revisitar a base neurobiológica do comportamento de fuga das baratas", diz ele. "0 comportamento de fuga é controlado por um número de neurônios que são direcionalmente sensiveis.

Portanto, as direções específicas de escape podem ser o resultado desses neurônios", conclui Domenici.

A pesquisa também tem seu lado prático. Confrontado com uma barata, já se pode prever o melhor lugar para mirar o chinelo. "Embora nós gostemos de baratas e não recomendamos o esmagamento. Cada animal é especial à sua própria maneira", diz 0 pesquisador.

\begin{tabular}{l}
\hline LEIA MAIS \\
\hline Urubu pré-histórico gigante habitou Minas Gerais \\
Cientistas revelam origem de polvos de grandes profundidades \\
\hline ESPECIAL \\
\hline Leia o que já foi publicado sobre baratas \\
LIVRARIA
\end{tabular}

- Livro traz 1001 maneiras de CUIDAR DE CASA, saúde e beleza de forma natural с айlyniua

10. TSE nega direito de resposta de Dilma em programa de Serra po conta de luz
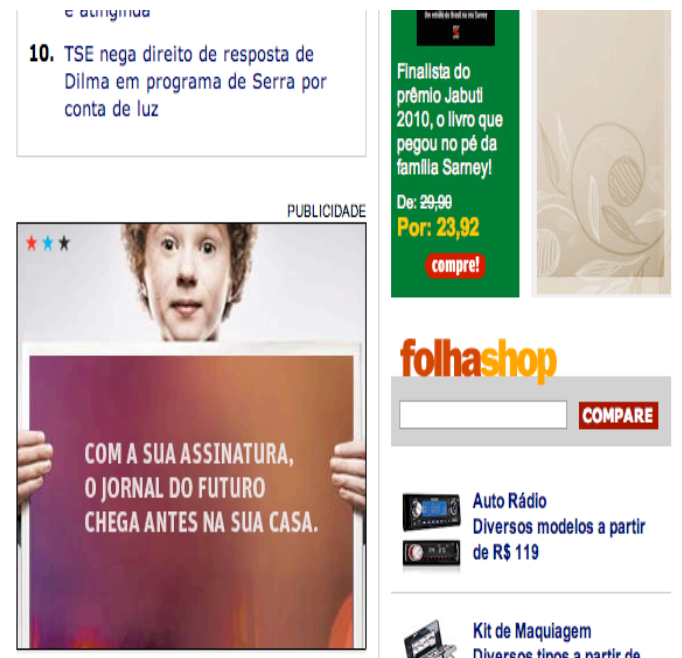

follhashop

+ lidas

1. Exame de sangue pode detectar Alzheimer, diz estudo

2. Concurso para professor universitário ignora pós multidiscrinlinar

3. Cientista alerta sobre superbactéria resistente a quase todos antibióticos

4. Graduação não tradicional complica candidatura à vaga de professor

5. Meteorito que caiu na França tem estillhaços de supernova

+ comentadas

1. Felicidade custa R\$ 11 mil por mês, aponta estudo
COMPARE
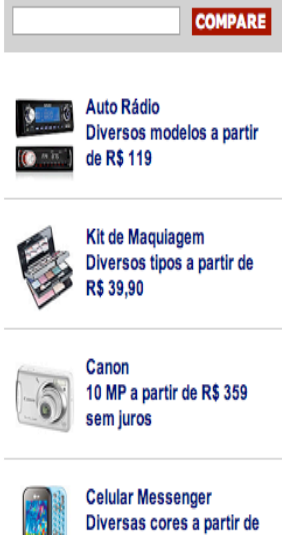

(26) $\mathrm{R} \$ 324$

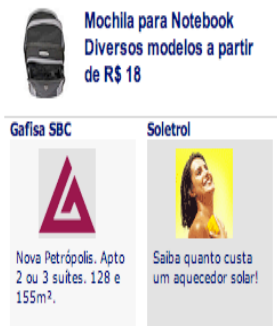

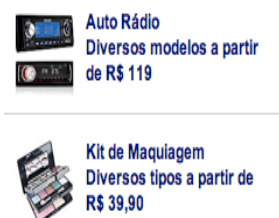

Nos anos analisados, o emprego da verbo-visualidade foi ampliado no ano de 2008 nos dois jornais. A FO utilizou imagens legendadas da NASA para ilustrar a reportagem (1) enquanto, na FSP, a mesma reportagem possui um elemento infográfico mais elaborado: um esquema explicativo com as etapas do processo de descoberta dos novos planetas pelos astrônomos. Essas são informações adicionais ao enunciado, o que gera uma relação de complementaridade. A segunda reportagem da FSP também é composta verbo-visualmente por um esquema explicativo da rota de fuga das baratas, além de contar com uma foto do inseto. As relações dialógicas hipertextuais que despontam da dimensão verbo-visual dos enunciados tanto da FO quanto da FSP serão exploradas ao longo das seções seguintes. 


\subsubsection{A maior autonomia dos infográficos: novos parâmetros para a conclusibilidade temática e composicional do enunciado verbo-visual na FSP}

Em 2008, cada meio possuía uma característica importante: a dimensão verbo-visual da FO foi enriquecida em uma das reportagens com a inserção de duas imagens fotográficas e o esquema explicativo da FSF adquiriu ainda mais autonomia composicional e temática, como mostraremos ao longo da seção.

$\mathrm{Na} \mathrm{FO}$, as imagens provenientes de agências de observação espacial - uma delas identificada é a Gemini Observatory - foram veiculadas na reportagem Astrônomos fazem $1^{a}$ foto de um sistema extra-solar ${ }^{78}$. As fotografias tiradas pelo telescópio são reproduzidas somente no jornal digital, como constatação do feito científico: a descoberta de novos planetas. A relação dialógica que as imagens estabelecem com a dimensão verbal do enunciado é a de indexação para legitimação da esfera científica.

Figura (59) - Reprodução de fragmento da reportagem da FO de 14 de novembro de 2008, Astrônomos fazem $1^{a}$ foto de um sistema extra-solar



\footnotetext{
${ }^{78}$ A reportagem Baratas tem estratégia para rota de fuga não possui elementos visuais na publicação digital.
} 
Figura (60) - Reprodução de fragmento da reportagem da FO de 14 de novembro de 2008, Astrônomos fazem $1^{a}$ foto de um sistema extra-solar

Além de Marois, escreve na "Science" o grupo de Paul Kalas, da Universidade de Berkeley, que detectou um planeta com massa bem menor (da ordem de dois Jupíteres), mas com imagem um pouco ofuscada pelo disco de gás e poeira em torno de sua estrela-mãe.

Esse mar de detritos é comum em estrelas bem mais jovens que o Sol. Por causa disso, os planetas descobertos devem ajudar o debate sobre a formação do próprio Sistema Solar. Marois afirma que o sistema descoberto por seu grupo é mesmo uma espécie de "versão ampliada do Sistema Solar".

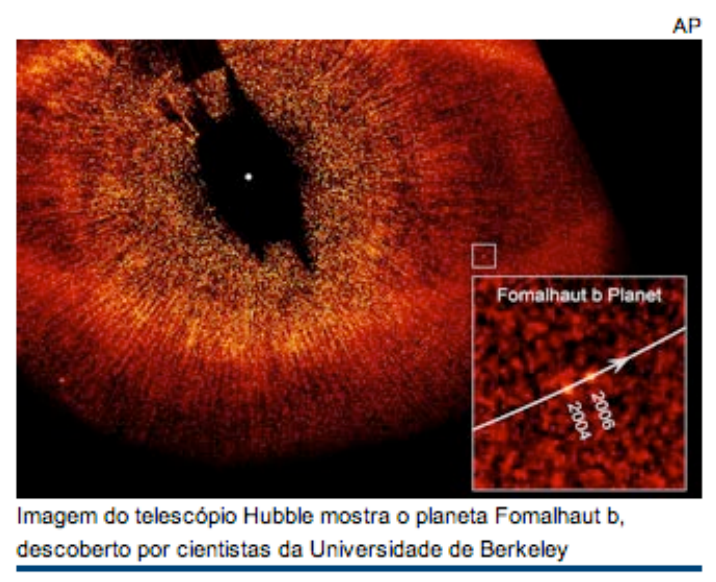

Na FSP, a configuração verbo-visual é mais complexa nas duas reportagens. A respeito da hiperestrutura da página, notamos que não há um enunciado-fonte, mas sim uma reportagem principal que ocupa mais espaço na página, cujos elementos peritextuais - título e subtítulo - possuem fontes maiores. Entre as reportagens, há uma linha demarcando a conclusibilidade de cada enunciado, também delineada pela alternância de autoria.

O infográfico verticaliza-se paralelamente ao enunciado, chegando a ultrapassar a barreira do cabeçalho da página. Nele, temos a demonstração do procedimento adotado pelos astrônomos para a detecção de novos planetas a partir da sequenciação de passos. Ao final do infográfico, verificamos a presença de um box explicativo cuja relação dialógica é a de situar os planetas no espaço, caracterizando o tempo-espaço do objeto da pesquisa. Há ainda a inserção de uma expressão popular que não participa da esfera científica: "Ver para crer". Verificamos que o enunciado é atravessado pela esfera da ideologia do cotidiano como forma de aproximar ainda mais o leitor não especialista do objeto discursivo.

Em seguida, destacamos a reprodução do esquema explicativo da primeira reportagem da FSP: 
Figura (61) - Reprodução de fragmento da reportagem da FSP de 14 de novembro de 2008, Astrônomos fazem $1^{a}$ foto de um sistema extra-solar

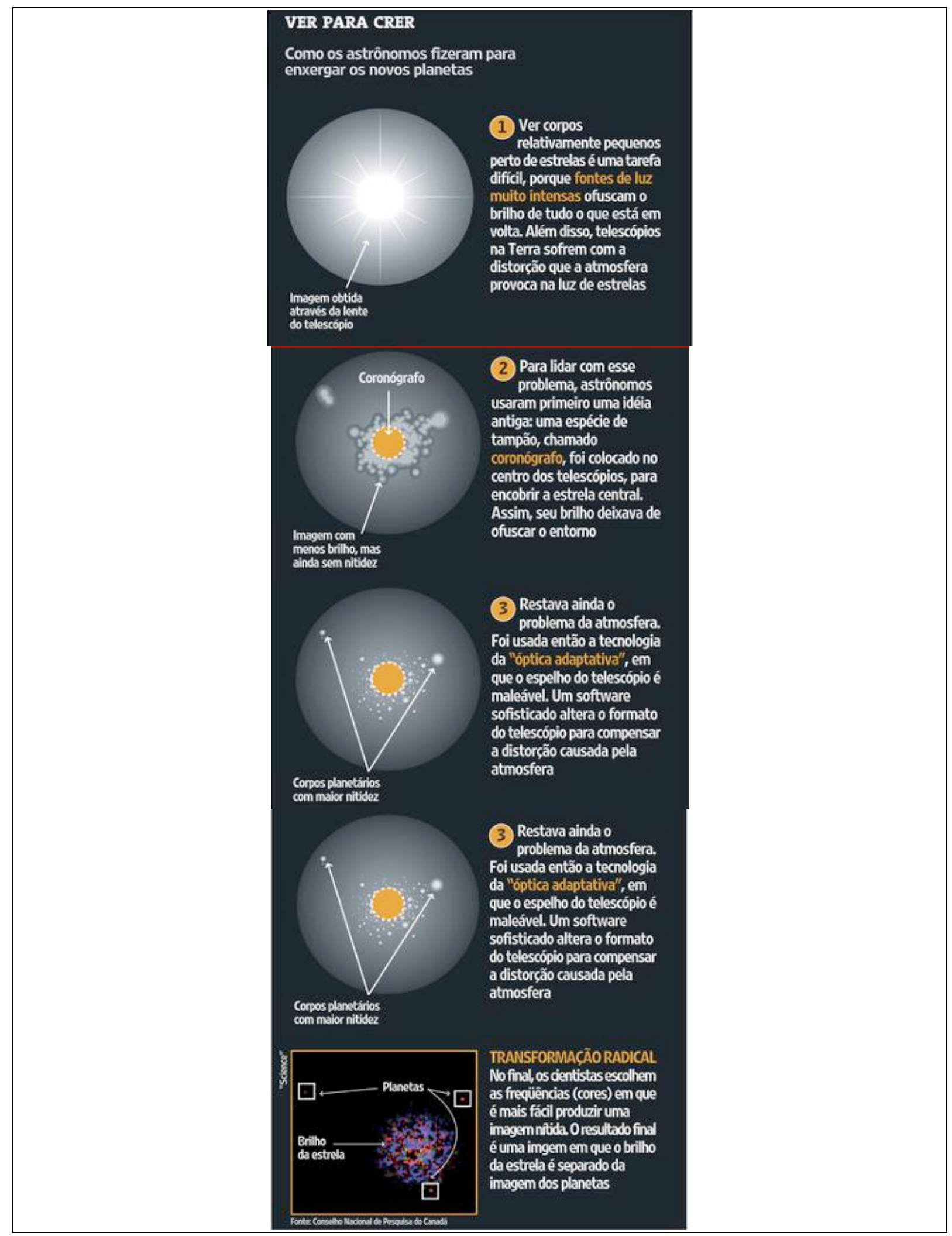


A autonomia composicional, tal como resumimos no título da seção, pode ser visivelmente notada, sobretudo pelo fundo negro que demarca o esquema explicativo. Contudo, a autonomia também está no eixo temático do esquema que apresenta mais relações dialógicas internas: a relação de sequenciação entre as partes e a relação com o box explicativo identificador do tempo-espaço. Por meio do esquema, não é possível sabermos que a constatação é dotada de controvérsias, tema da dimensão verbal da reportagem. $\mathrm{O}$ enunciado repercute a opinião de diversos especialistas e o fato de que não há um ponto de concordância entre os especialistas é resumido pela fala do astrônomo Gustavo Mello: “É bom esperar um pouquinho antes de bater o martelo, apesar de ser um trabalho convincente".

A dimensão verbo-visual da segunda reportagem é formada também por um esquema explicativo, que descreve a rota de fuga das baratas, e uma fotografia, como dispomos nas figuras (61) e (62) a seguir:

Figura (62) - Reprodução de fragmento da reportagem da FSP de 14 de novembro de 2008, baratas tem estratégia para rota de fuga

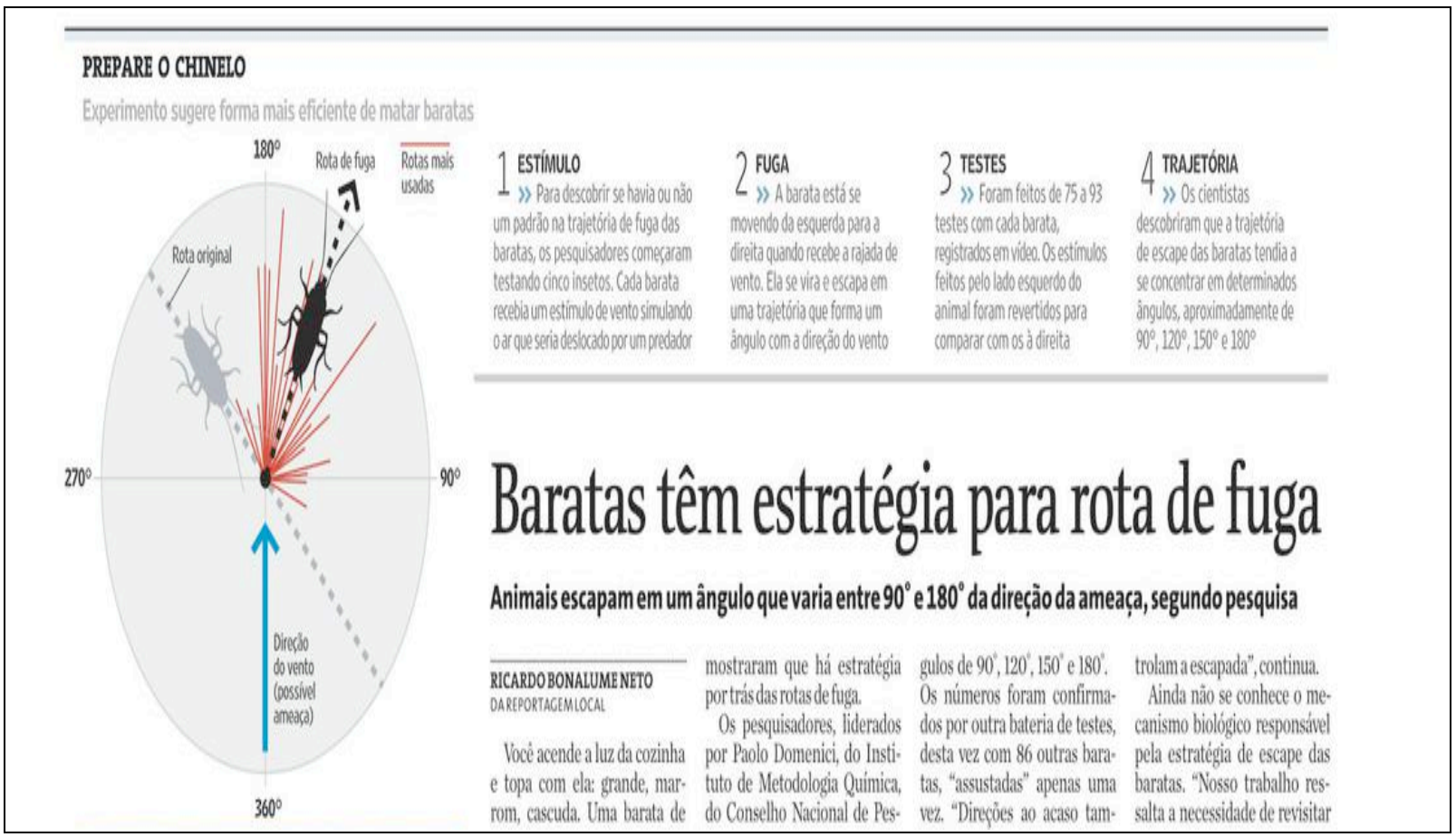


Figura (63) - Reprodução de fragmento da reportagem da FSP de 14 de novembro de 2008, baratas tem estratégia para rota de fuga

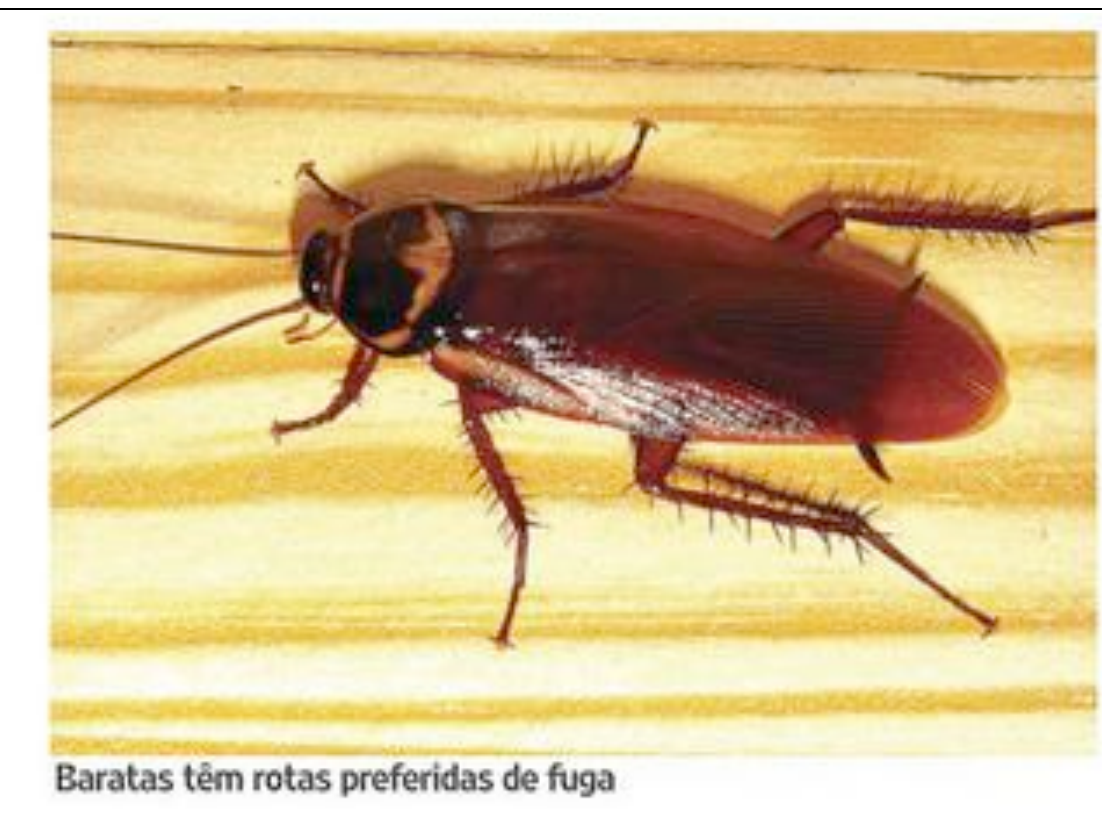

A questão da autonomia observada na reportagem anterior verifica-se nos enunciados que acabamos de reproduzir. Na figura (61), o esquema explicativo indexa a dimensão verbal da reportagem, como uma espécie de cabeçalho, antecedendo e antecipando o conteúdo da reportagem. $\mathrm{O}$ esquema explicativo possui passos sequenciados indicando a metodologia da pesquisa e todas as suas partes: justificativa e hipótese, testes e resultados.

\subsubsection{Um novo tipo de remissão hipertextual na FO}

No que tange aos nós remissivos em 2008, não foram encontradas ocorrências na página do jornal impresso e os tipos de remissão da FO mantiveram-se iguais ao ano anterior. Um primeiro nível pode ser verificado na figura (63) em que um fragmento do enunciado é destacado, levando o leitor a uma outra reportagem da FO com a caracterização dos maiores telescópios do mundo. Nesse caso, temos um exemplo de relação dialógica hipertextual de plano primário interno cuja função é de complementar por meio de adição de novos dados: 
Figura (64) - Reprodução de fragmento da reportagem da FO de 14 de novembro de 2008, Astrônomos fazem $1^{a}$ foto de um sistema extra-solar

\title{
Astrônomos fazem $1^{\text {a }}$ foto de um sistema extra-solar
}

\author{
RAFAEL GARCIA \\ da Folha de S.Paulo
}

$8 + 1 \longdiv { 0 }$

Dois grupos independentes de astrônomos anunciam hoje ter conseguido avistar diretamente planetas orbitando outras estrelas. Esses corpos celestiais que orbitam outras estrelas já haviam sido detectados de modo indireto e até fotografados antes, mas as imagens obtidas dependiam de confirmação. Agora, os exoplanetas foram flagrados se movendo ao redor de suas estrelas.

Os cientistas descrevem a descoberta em dois artigos na revista "Science". Um dos grupos achou três exoplanetas em torno de uma estrela na constelação do Sagitário usando técnicas especiais para modificar imagens dos telescópios Gemini e Keck, no Havaí (EUA).

Apontamos uma novidade em relação ao tipo de remissão veiculado ao final do enunciado de ambas as reportagens de 2008 na FO. Além da seção "Leia Mais" que complementa a informação do enunciado-fonte e o situa em meio a eventos anteriores e da seção "Especial" que o direciona à ferramenta de busca do portal, também possibilitando o acesso a mais dados, há a inserção de um item para venda de produtos do PubliFolha, livraria do Grupo Folha.

Figura (65) - Reprodução de fragmento da reportagem da FO de 14 de novembro de 2008, Astrônomos fazem $1^{a}$ foto de um sistema extra-solar

Sua técnica, porém, ainda não vê

planetas pequenos como a Terra. "Para achar esses planetas seria preciso um telescópio espacial com aparatos muito modernos", diz. "Podem se passar 20 ou 30 anos até lá."

LEIA MAIS

- Cientistas vêem aurora "sinqular" em Saturno

- Conheça os qrandes telescópios do planeta

- Partícula "fantasma" surge em colisão em acelerador nos EUA

- Nasa cancela nova missão de reparo do telescópio Hubble

- Hubble volta a funcionar e divulga imagem nova do espaço

\section{LIVRARIA}

- Livro desvenda MARTE, explica os mitos do planeta e revela curiosidades

- Entenda os TEMAS ATUAIS da ciência em livro de Marcelo Gleiser

\section{ESPECIAL}

- Leia o que já foi publicado sobre espaço 
Figura (66) - Reprodução de fragmento da reportagem da FO de 14 de novembro de 2008, Baratas tem estratégia para rota de fuga

Portanto, as direções específicas de escape podem ser o resultado desses neurônios", conclui Domenici.

A pesquisa também tem seu lado prático. Confrontado com uma barata, já se pode prever o melhor lugar para mirar o chinelo. "Embora nós gostemos de baratas e não recomendamos o esmagamento. Cada animal é especial à sua própria maneira", diz o pesquisador.

\section{LEIA MAIS}

- Urubu pré-histórico gigante habitou Minas Gerais

- Cientistas revelam origem de polvos de grandes profundidades

ESPECIAL

- Leia o que já foi publicado sobre baratas

LIVRARIA

- Livro traz 1001 maneiras de CUIDAR DE CASA, saúde e beleza de forma natural

A indicação de livros é feita de acordo com o assunto da reportagem acima, podendo apresentar uma relação direta, como na figura (64) ou mais indireta, segundo demonstra o exemplo da figura (65). Trata-se de uma nova forma de ancorar os produtos à reportagem, o que destaca o aparecimento da esfera publicitária no domínio da reportagem digital. Lembramos que não é possível recuperar as peças publicitárias da FO em cada ano analisado, por conta da atualização constante sofrida por esse tipo de enunciado na rede. Se acessarmos hoje o enunciado acima, a peça publicitária será atual e não corresponderá à época de publicação. Inserir o anúncio nos limites composicionais do enunciado é uma forma de manter o vínculo atualizado, além de promover a sugestão de uma possível relação entre a reportagem e a obra que está sendo oferecida. Compreendemos que a página e suas peças publicitárias não configuram o contexto do enunciado na internet, diferentemente do meio impresso.

\subsubsection{Síntese}

No segundo período de análise observamos mudanças significativas no modo de veicular o discurso de DC tanto na FO quanto na FSP. O início de tal fenômeno deu-se em 2006, com a reconfiguração do estilo e forma composicional das reportagens impressas. Em 2007, além da inserção de imagens no corpo do enunciado da FO, os infográficos da FSP pareciam adquirir um aspecto mais autônomo em relação à dimensão verbal do enunciado. 
Esse fato foi comprovado pela análise das reportagens do ano 2008, em que pudemos averiguar como o conteúdo temático do componente verbal relaciona-se com o conteúdo temático dos esquemas explicativos. Nas considerações finais, formulamos um quadro com as relações dialógicas encontradas ao longo de toda a pesquisa, bem como apresentamos as principais descobertas da tese que visa estabelecer a hipertextualidade como um tipo de relação dialógica entre enunciados impressos e digitais. 


\section{CONSIDERAÇÕES FINAIS}

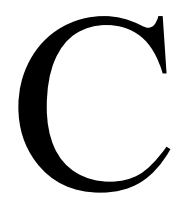

om o objetivo principal de definir o que é e como ocorre a hipertextualidade, a presente tese de doutorado partiu de uma perspectiva bakhtiniana. Tendo como eixo condutor o modelo metalinguístico elaborado por Mikhaïl Bakhtin no conjunto de suas obras e também os conceitos propostos por Volóchinov e Medevdev fundamentamos a hipertextualidade como um tipo de relação dialógica entre enunciados participantes de uma mesma rede de sentido, interligados por algum mecanismo de remissão. Considerando a ocorrência da hipertextualidade tanto em meio impresso e quanto digital, retomamos a pergunta de pesquisa inicial:

Enquanto uma modalidade de relação dialógica, como se configura a hipertextualidade em enunciados de divulgação científica colocados em rede por algum mecanismo de remissão nos meios impresso e digital?

Mesmo impulsionada por um eixo teórico específico, a pesquisa buscou um diálogo com outras teorizações cujo foco também se voltava para a relação entre textos e discursos, reverenciando alguns autores da Crítica Literária, da Linguística Textual e da Análise do Discurso francesa. Longe de esgotarmos a complexidade de cada uma, nosso olhar dirigiu-se aos conceitos de intertextualidade, transtextualidade, interdiscursividade e heterogeneidade. O estudo lançado sobre tais conceitos e sua proximidade com a noção de dialogismo resultou no primeiro capítulo da tese. A conjuntura teórica apresentada foi um reflexo do estado da arte dos estudos sobre o hipertexto no cenário brasileiro, iniciados no escopo da LT.

O que nos levou ao estudo da intertextualidade, desde sua origem na Teoria Literária a sua apropriação pela LT, foi o fato de que vários autores passaram a considerá-la um dos aspectos caracterizadores do hipertexto, conforme discorremos anteriormente. Por sua vez, a forma com que a noção de intertextualidade foi operacionalizada nesse contexto motivou-nos a formular uma proposta sob a lupa bakhtiniana. A nosso ver, tanto a intertextualidade stricto sensu - em que destacamos os tipos de discurso citado - quanto a hipertextualidade são 
modalidades de relações dialógicas. Enquanto a primeira concretiza o discurso de outrem no enunciado, em um movimento de fora para dentro deste, a hipertextualidade é dinamizada pela remissão a um enunciado externo. Logo, a intertextualidade não caracteriza o hipertexto, mas pode ser parte dele ao lado de outras relações dialógicas, ao passo em que a hipertextualidade é o aspecto característico e intrínseco ao hipertexto. A incorporação da voz de outrem e a remissão a outro enunciado certamente geram relações de sentido específicos.

Tendo como conceito-chave a noção de relações dialógicas bakhtinianas, partimos do pressuposto de que os enunciados relacionam-se entre si devido à sua responsividade e, quando defrontados em um mesmo plano de sentido, estabelecem relações semânticas entre si. A partir dessa premissa, Julia Kristeva propôs que o texto romanesco é constituído por um mosaico de outros textos tanto em um nível implícito ou constitutivo, quanto em um nível explícito. Apesar de a concepção de intertextualidade possuir natureza diferente da de relações dialógicas, mesmo porque Kristeva formula uma teoria para a análise de textos literários, enquanto o Círculo considera que as relações dialógicas estão presentes em todo o tipo de enunciado, a autora estabelece uma relação direta entre as duas noções.

A intertextualidade de Kristeva, por sua vez, inspirou as propostas de Genette e de autores da LT. No entanto, a noção foi apreendida de forma distinta. Para o primeiro autor, que não faz referência ao dialogismo bakhtiniano, a intertextualidade é um tipo de relação transtextual ao lado da paratextualidade, da arquitextualidade, da metatextualidade e da hipertextualidade. De acordo com a sua teoria, a intertextualidade é explicitada pela manifestação de um texto em outro, enquanto a hipertextualidade compreende a presença de elementos que remetem um texto (a) a um texto (b). Para a LT, a intertextualidade também pode ser compreendida como a manifestação de um texto em outro no sentido strictu sensu. Entretanto, ao contrário de Genette, a LT considera a dimensão lato sensu em que a intertextualidade não é explicitamente marcada no texto.

Tais definições levaram-nos a considerar que a hipertextualidade, tal como a propomos, também é articulada por aspectos da forma composicional, estilo e conteúdo temático dos enunciados. As relações hipertextuais possuem uma dimensão dialógica que é inerente ao enunciado e, portanto, constitutiva e dentro da perspectiva bakhtiniana não podem ser reduzidas ao aspecto composicional. A hipertextualidade pode ser definida como uma modalidade de relação dialógica, assim como pode ser considerada a intertextualidade, que é manifestada por meio da articulação de enunciados e aspectos da sua forma composicional - tal como a hiperestrutura, o hipertexto e a dimensão verbo-visual do 
enunciado, e todo tipo de enunciado que apresente um nó remissivo -, bem como aspectos estilísticos e temáticos.

Em um segundo momento, também fomos levados a refletir sobre o caráter impresso e digital dos enunciados selecionados com base nas definições de meio, suporte e esfera no âmbito de diferentes teorias. Portanto, o segundo capítulo voltou-se à busca de um posicionamento teórico que acabou por definir a internet como conjunto de esferas da atividade humana e espaço social de interação entre os sujeitos. As teorias estudadas ao longo do capítulo auxiliaram no entendimento dos conceitos de suporte e meio.

Inicialmente, observamos que tanto McLuhan, Debray e Lévy distinguem o suporte físico do meio. Também partimos da premissa de que o suporte não se confunde com o meio. No entanto, as noções de meio em McLuhan e Debray não são equivalentes. Para o primeiro autor, o 'meio' equivale ao meio de comunicação ou transmissão que pode se entendido como uma extensão do corpo humano, ao mesmo tempo em que é parte da própria mensagem que transmite. Não adotamos tal concepção por não concordamos com o processo de desdobramento do corpo em meio proposto por McLuhan. Já Debray discorre sobre o conceito de mídium, um conjunto de fatores que equivale ao meio de transmissão, tal como o autor prefere denominar. O mídium é dotado de quatro elementos: o procedimento de simbolização (fala, escrita, imagem e cálculo digital); o código de comunicação que equivale à própria língua natural; o suporte material de inscrição e estocagem da informação; e o dispositivo de registro. Embora a noção de meio possa ser entendida como o tipo de dispositivo de registro na teoria de Debray, para a produtividade de nossa pesquisa, propomos uma medida teórica para caracterizar os veículos que situam tanto a FSP quanto a FO.

O meio define-se pelos seguintes fatores: o suporte e suas respectivas semioses; os enunciados e gêneros discursivos que comportam; a relação interativa mais ou menos imediata entre locutores e interlocutores; e o conjunto de práticas de produção, circulação e recepção que envolve a informação. Nesse sentido, nossa visão sobre o meio difere do conceito de mídium. A partir de tal conceito, a internet é um meio possibilitado por diferentes suportes e caracterizado por um sistema de semioses complexo. A digitalidade transforma a internet em espaço digital - ciberespaço, tal como propôs Levy (1999) - de comunicação e interação verbal e não-verbal entre os sujeitos falantes.

Estendendo a discussão sobre os meios, a análise dos enunciados fez-nos avançar no refinamento da reflexão sobre a internet, disposta no meio, um canal entre a infra e a superestrutura. A geração de novas tecnologias dá-se na infraestrutura, mas certamente é 
motivada pelos processos complexos da cultura. O meio está na relação direta com a esfera e não com o gênero, tal como apontou Marcuschi (1999) em seu artigo sobre o hipertexto. $O$ modo de inscrição certamente é um dos elementos determinantes para a concretização dos enunciados e para a manifestação dos gêneros, tal como vimos na questão da conclusibilidade do enunciado impresso e digital. Se a reportagem da FSF é constituída por conjuntos de enunciados capazes de gerar uma tematicidade única, a FO apresenta a mesma forma lógica e juízos de valores de maneira autônoma, o que faz com que as relações dialógicas hipertextuais sejam distintas. Com isso, queremos afirmar que o meio, apesar de interferir no processo de concretização dos gêneros, é um aspecto situado na esfera da atividade humana.

O meio, como um reflexo dos avanços infraestruturais e culturais da sociedade, interligando os processos de produção, circulação e recepção de enunciados, assim que seus conteúdos são materializados pelas formas da linguagem verbal ou não verbal. Consideramos ainda que o meio não é capaz de gerar uma esfera, mas sim pode modificá-la, como no caso da Internet. O meio impresso parece ter fortalecido práticas de dadas esferas, como, por exemplo, a jornalística, mas que surgiu da incorporação de gêneros advindos de outra esfera. A internet, por sua vez, parece passar por um momento semelhante atualmente, ao incorporar esferas da atividade humana que existem fora dela. Em contrapartida, a rede consegue congregar gêneros orais, televisivos e radiofônicos, cujas formas de inscrição fogem ao escopo do meio impresso.

Assim como afirma Araújo (2004), concordamos com o fato de que exista uma esfera digital, mas propomos a transposição dessa mesma esfera sobre as demais. Com tal afirmação, sugerimos que a esfera digital envolve as demais esferas na rede mundial de computadores com suas características tecnológicas específicas. Vivenciamos um momento único na História, talvez somente passível de ser comparado ao advento da Imprensa ou da própria escrita, pois podemos ver a relação da esfera digital com as demais, contudo, sem ainda compreender todos os processos de complexificação que a envolvem. Futuramente, a estabilização das esferas e a autonomia dos gêneros e enunciados digitais - tendência que se confirmou inclusive em nossa tese - poderá ser observada com mais clareza.

Uma vez projetados os conceitos de hipertextualidade, suporte, meio, mídium e internet para o desenvolvimento da pesquisa, elaboramos um capítulo dedicado à descrição do corpus e das categorias e formas de análise que seriam adotadas. O próximo passo foi elaborar os critérios de escolha e seleção do corpus, bem como à delimitação das categorias de análise e dos procedimentos analíticos que seriam adotados, contribuindo para um modelo 
de análise dialógica. Por fim, desenvolvemos a análise das reportagens que compõem o corpus final da pesquisa.

Selecionamos reportagens de divulgação científica comuns entre a FSP e a FO. Isto é, foram escolhidas reportagens cujos textos e títulos eram os mesmos e que haviam sido publicadas na mesma data. O corpus final foi composto pelo equivalente a uma página do jornal impresso por ano, entre 2000 e 2008.

Nosso modelo dialógico de análise, baseado nos princípios bakhtinianos, revelou uma produtividade da relação interativa entre os preceitos teórico-metodológicos empenhados e a análise. Se por um lado fomos direcionados pela teoria dialógica e pela reflexão de outros modelos teóricos, adotando diretrizes e refletindo sobre a constituição de um modelo de análise que nos auxiliasse a responder a pergunta de pesquisa, por outro a própria análise forneceu-nos subsídios para que aprimorássemos o modelo. Mais do que falar, o corpus dialoga, o que nos fez voltar para o modelo de análise do terceiro capítulo para discorrer sobre a conclusibilidade dos enunciados do gênero reportagem de DC impresso e digital presentes na tese.

Seguimos com a análise que, inicialmente, fez-nos constatar que as relações dialógicas hipertextuais estavam relacionadas a aspectos composicionais dos enunciados, sendo articuladas pela hiperestrutura, em maior incidência nos enunciados impressos que em digitais. Denominamos enunciado-fonte, aquele que contém algum tipo de nó remissivo, formando um hipertexto. No que tange aos aspectos da forma composicional, o hipertexto não é o único articulador da hipertextualidade e o nó eletrônico não constitui o seu único mecanismo de remissão. A hiperestrutura é uma forma de organização de enunciados em meio impresso capaz de colocar o enunciado-fonte em relação imediata com os demais enunciados. A diferença entre os enunciados da FSP e da FO está exatamente nos planos de remissão que definimos. Enquanto no jornal impresso o enunciado fonte relaciona-se com outro enunciado na mesma reportagem, na mesma página, em outras páginas do jornal, ou mesmo fora dele, a hipertextualidade no jornal digital otimiza o uso de nós remissivos, sempre articulando enunciados de uma página a outra.

Os nós remissivos podem possuir natureza variada, não se resumindo aos links eletrônicos. Identificamos que elementos dêiticos da dimensão verbal podem articular uma remissão, assim como aspectos da dimensão verbo-visual do enunciado, exemplo dado na primeira análise. Há também uma hipertextualidade não marcada que ocorre quando o enunciado fonte relaciona-se com enunciados dispostos no jornal como um todo. Entretanto, ressaltamos que a hipertextualidade não marcada só é possível quando o leitor é capaz de 
recuperar a relação dialógica entre os enunciados, o que não ocorre na FO. Isso se deve ao volume de informação agrupado em um mesmo tempo-espaço, fronteiras demarcadas no jornal impresso pelas páginas e cadernos, cuja característica volátil e instantânea da internet apaga. É interessante pensar que a rede possibilita com que tenhamos acesso fácil a todo o conteúdo que já veiculou, no entanto, ela não é capaz de preservar as mesmas relações dialógicas circunscritas no impresso.

O percurso de análise adotado procurou dar conta do contexto sócio-histórico dos enunciados, bem como a autoria e a presença do leitor presumido. Em seguida, partimos para a análise dos elementos constitutivos do gênero reportagem de DC, considerando as coerções de cada meio. Ao longo do desenvolvimento da presente tese, procuramos apresentar os objetivos centrais e a justificativa da pesquisa, bem como delinear a sua fundamentação teórica e procedimentos metodológicos que nos levam a estabelecer uma proposta acerca da hipertextualidade enquanto instância dialógica da linguagem. Além disso, pontuamos os aspectos levantados a partir da análise dos enunciados impressos e digitais que compõem o corpus.

Os capítulos analíticos trouxeram elucidações no tocante às relações dialógicas hipertextuais encontradas ao longo dos anos de análise. A seguir, apresentamos um quadro resumido com os diferentes tipos de relação dialógica e seus respectivos planos de remissão em cada ano e publicação: 
Tabela (13) Quadro resumido das relações dialógicas no primeiro período de análise

\begin{tabular}{|c|c|c|c|}
\hline Ano & Tipo de relação dialógica hipertextual & Plano de remissão ${ }^{79}$ & Publicação \\
\hline \multirow{3}{*}{2000} & $\begin{array}{l}\text { Concordância como reforço do argumento do } \\
\text { enunciado-fonte }\end{array}$ & Interno secundário & FSP \\
\hline & $\begin{array}{l}\text { Concordância como reforço do argumento do } \\
\text { enunciado-fonte: polêmica aberta }\end{array}$ & Externo secundário & FO \\
\hline & $\begin{array}{l}\text { Ocultação ou evidência de elementos em polêmica } \\
\text { velada para reforço do argumento anterior }\end{array}$ & Externo primário & FSP \\
\hline \multirow{4}{*}{2003} & Complementação para caracterização do tempo-espaço & Interno primário & FSP \\
\hline & Indexação de elemento legitimador da esfera científica & Interno primário & FSP \\
\hline & Concordância para direcionar uma polêmica velada & $\begin{array}{l}\text { Interno secundário ao } \\
\text { externo }\end{array}$ & FSP \\
\hline & $\begin{array}{l}\text { Complementação por meio da introdução de novos } \\
\text { dados }\end{array}$ & Externo secundário & $\mathrm{FO}$ \\
\hline \multirow{3}{*}{2005} & Indexação de elemento legitimador da esfera científica & Interno primário & $\begin{array}{l}\text { FSP } \\
\text { FO }\end{array}$ \\
\hline & Complementação para caracterização do tempo-espaço & Interno primário & FO \\
\hline & $\begin{array}{l}\text { Complementação por meio da introdução de novos } \\
\text { dados }\end{array}$ & Externo secundário & FO \\
\hline
\end{tabular}

Analisando o quadro do primeiro período, notamos relações dialógicas hipertextuais distintas em cada meio. Somente em 2005, houve um mesmo tipo de relação dialógica hipertextual na forma lógica comum da FSP e da FO. Em 2000 e 2003, a FO geralmente articula a hipertextualidade em planos secundários externos, isto é, remete o enunciado a

\footnotetext{
${ }^{79}$ Retomando os planos de remissão identificados no início do quarto capítulo, temos: planos de remissão interno ou externo. Os internos subdividem-se em primário e secundário, sendo que o primeiro tipo refere-se à relação dialógica hipertextual entre as dimensões verbais e verbovisuais do enunciado-fonte e o segundo diz respeito à relação entre o enunciado-fonte e qualquer outro enunciado indexado, compondo uma única reportagem. Este último só foi observado no primeiro ano de análise na FSP. Já os planos externos também são encontrados em nível primário e secundário: primário quando uma reportagem está relacionada a outra no espaço da mesma página, fato possível de ser verificado somente na hiperestrutura do jornal impresso. Enquanto isso, o secundário resulta da relação hipertextual entre um enunciado-fonte e enunciados de outras páginas tanto do jornal impresso quanto digital.
} 
uma página externa do próprio site ou a outros sites. Em 2005, os enunciados da FO passaram a promover relações dialógicas hipertextuais também no interior do enunciado, fenômeno que se consolidará nos ano seguintes, como podemos observar no quadro do segundo período.

Tabela (14) Quadro resumido das relações dialógicas no segundo período de análise

\begin{tabular}{|c|c|c|c|}
\hline Ano & Tipo de relação dialógica hipertextual & Plano de remissão & Publicação \\
\hline \multirow{3}{*}{2006} & $\begin{array}{l}\text { Complementação por meio da introdução de novos } \\
\text { dados }\end{array}$ & $\begin{array}{l}\text { Interno primário, } \\
\text { interno secundário e } \\
\text { externo secundário }\end{array}$ & $\begin{array}{l}\text { FSP } \\
\text { FO }\end{array}$ \\
\hline & Indexação de elemento legitimador da esfera científica & $\begin{array}{l}\text { Interno primário } \\
\text { Externo secundário }\end{array}$ & $\begin{array}{l}\text { FSP } \\
\text { FO }\end{array}$ \\
\hline & Complementação para caracterização do tempo-espaço & Interno primário & $\begin{array}{l}\text { FSP } \\
\text { FO }\end{array}$ \\
\hline \multirow{7}{*}{2007} & Resumo de conteúdo para captação do leitor & Externo secundário & FSP \\
\hline & Complementação sequencial & Interno primário & FSP \\
\hline & Polêmica aberta & Interno primário & FSP \\
\hline & Explicação introdutório & Interno primário & FSP \\
\hline & $\begin{array}{l}\text { Aprofundamento e legitimação da fonte na esfera } \\
\text { científica }\end{array}$ & Externo secundário & FO \\
\hline & Complementação para caracterização do tempo-espaço & Externo secundário & FO \\
\hline & $\begin{array}{l}\text { Complementação por meio da introdução de novos } \\
\text { dados }\end{array}$ & Externo secundário & FO \\
\hline \multirow{4}{*}{2008} & Indexação de elemento legitimador da esfera científica & Interno primário & FO \\
\hline & Complementação para caracterização do tempo-espaço & Interno primário & FSP \\
\hline & Complementação sequencial & Interno primário & FSP \\
\hline & $\begin{array}{l}\text { Complementação por meio da introdução de novos } \\
\text { dados }\end{array}$ & Interno primário & FO \\
\hline
\end{tabular}


No ano de 2006, deparamo-nos com exemplos de representação do link eletrônico nas páginas impressas, evidenciando não somente uma maior autonomia na produção dos enunciados da FO, como também uma mudança estilístico-composicional na FSP. Tal fato pode ser relacionado à estabilização e fortalecimento da DC em ambas as publicações e em todo o cenário nacional. Ainda neste ano, todas as relações dialógicas encontradas na FSP, puderam também ser observadas na FO, aspecto muito diferente do que mostramos no primeiro quadro. Contudo, em 2007 vemos que cada jornal passa a articular relações dialógicas distintas novamente indicando que 2006 foi um ano de mudanças e desestabilização de ambos os jornais. Em 2007, ainda tivemos o maior índice de relações dialógicas e a diversificação acometeu tanto a FO quanto a FSP. Em 2008, a imagem que antes travava uma relação dialógica interna primária em relação ao enunciado-fonte, com o advento do infográfico, faz a dimensão verbo-visual adquirir certa autonomia que modifica essa relação dialógica hipertextual. Ainda em nível interno, por constituírem a mesma reportagem, o aspecto primário passa a ser secundário.

Com a ajuda dos quadros (1) e (2), faz-se possível visualizar a evolução do discurso de DC ao longo da primeira década de existência da FO tanto no jornal impresso quanto no digital. Primeiramente, o discurso de DC constituía-se como uma arena para a discussão de fatos políticos do país, estando a editoria muito mais atravessada pela esfera política do que científica. Ao longo dos anos do primeiro período, os temas da esfera científica foram mais incorporados, mas a editoria ainda dividia espaço com as peças publicitárias, mais um fator indicativo de que o espaço ainda não estava dominantemente voltado à prática da DC. No segundo período, observamos que, além da inserção de esquemas explicativos e infográficos complexos na FSP, as peças publicitárias tomaram um espaço reduzido ou foram direcionadas a outras editorias, como a seção "Mundo". Enquanto isso, a FO adquiria certa autonomia editorial em relação à FSP, fazendo escolhas próprias e estabelecendo outras relações de sentido.

O discurso político que atravessava as reportagens de DC nos anos iniciais da análise não somente sofreu um apagamento, como também deu espaço para a inserção de expressões e temas voltados à esfera da ideologia do cotidiano, como observamos na análise do segundo período.

Com o exame da hipertextualidade no corpus, pudemos compreender a relação de força entre as esferas da atividade humana e a influência dos meios sobre os enunciados, 
resultando em novos parâmetros de conclusibilidade para o gênero reportagem. A página digital admite uma única reportagem constituído de somente um enunciado, enquanto a página impressa possibilita uma reportagem mais fragmentada, constituída por um ou mais enunciados. Tal fator possui uma implicação nas relações dialógicas articuladas entre os enunciados e reportagens. Ao passo que o enunciado-fonte é marcado no meio impresso pelo tamanho e centralidade de sua diagramação na página - o enunciado-fonte no meio digital torna-se relativo ao percurso de leitura do interlocutor. A subordinação que gera percursos de leitura mais delimitados no impresso desaparece no digital e o enunciado-fonte torna-se aquele que o leitor acessar primeiro. Buscamos elucidar que, seja partindo de um enunciado-fonte, ou mesmo no interior de um enunciado, a hipertextualidade está presente no meio digital e impresso, especializando-se, ao longo do tempo, de acordo com as características e cada um. 


\section{REFERÊNCIAS}

ADAM, Jean-Michel \& LUGRIN, Gilles. Effacement énonciatif et diffraction co-textuelle de la prise en charge des énoncés dans les hyperstructures journalistiques. In: RABATEL, Alain \& CHAUVIN-VILENO, Andrée. SEMEN, Presses Universitaires de Franche-Comté, $\mathrm{n}^{\mathrm{o}}$ 22, 2006. Consultado em 07 de fevereiro de 2009. Disponível em $<$ http://semen.revues.org/4381>.

ARAÚJO, J. C. R. de. A conversa na web: o estudo da transmutação em um gênero textual. In: MARCUSCHI, L.; XAVIER, A. Hipertexto e gêneros digitais. Rio de Janeiro: Lucerna, 2004, p.91-109.

ARAÚJO, J. C. R. Os chats: uma constelação de gêneros na internet. Tese de doutorado. Universidade Federal do Ceará, 2006.

AUTHIER-REVUZ, J. Hétérogénéité montrée et hétérogénéité constitutive: élément pour une approche de l'autre dans le discours. DRLAV, $\mathrm{n}^{\circ}$ 26. Paris, Centre de Recherche de l’université de Paris VIII, 1982, p. 91-151.

BAKHTIN, M. \& MEDEVDEV, P. The formal method in literary scholarship. Translated by Albert J. Wehrle. Baltimore and London: The Johns Hopkins University Press, 1991 [1928].

BAKHTIN, M. Os gêneros do discurso. In: Estética da criação verbal. Trad. Paulo Bezerra. São Paulo: Martins Fontes, 2003 [1952-53], p. 261-306.

. O problema do texto na lingüística, na filologia e em outras ciências humanas.

In: Estética da criação verbal. Trad. Paulo Bezerra. São Paulo: Martins Fontes, 2003 [1979].

/VOLOSHINOV. Marxismo e filosofia da linguagem. Trad. do francês de Michel Lahud e Yara Frateschi Vieira, 11ª ed. São Paulo: Hucitec, 2004 [1929]. 
BAKHTIN, Mikhail. Problemas da Poética de Dostoiévski. Trad. do russo de Paulo Bezerra, $5^{\mathrm{a}}$ ed. Rio de Janeiro: Forense Universitária, 2010 [1963].

BAKHTINE, M. Problème du contenu, du matériau et de la forme dans l'œuvre littéraire. In: Esthétique et théorie du roman. Trad. Daria Olivier. France: Gallimard, 2004 [1924], p. 21 82.

BAKHTINE, M. Pour une philosophie de l'acte. Trad. Ghislaine Capogna Bardet. France: Editions L'Age d'Homme, 2003 [1920-24].

BRANDIST, C. Bakhtin e os primórdios da sociolingüística soviética. In: FARACO, Carlos Alberto; TEZZA, Cristóvão \& CASTRO, Gilberto de (Orgs). Vinte ensaios sobre Mikhail Bakhtin. Petrópolis, RJ: Vozes, 2006.

BRAIT, B. A palavra mandioca do verbal ao verbo-visual. In: BAKHTINIANA, São Paulo, v. $1, \mathrm{n}^{\mathrm{o}} 1,2009, \mathrm{p} .142-160$.

BRAIT, B. Análise e teoria do discurso. In: BRAIT, Beth (Org.). Bakhtin: outros conceitoschave. São Paulo: Contexto, 2006.

BRISOLLA, Sandra N. \& CARVALHO, Ruy Q. Pesquisa Científica e Inovação Tecnológica: Avanços e Desafios. In: Indicadores de Ciência, Tecnologia e Inovação em São Paulo. FAPESP: São Paulo, 2001. Disponível em http://www.fapesp.br/publicacoes/indet/cap01/cap01.htm. Acessado em março de 2012.

CASTELlS, M. A sociedade em rede. São Paulo: Paz e Terra, 1999.

CEREJA, William. Significação e tema. In: BRAIT, Beth (org). Bakhtin: conceitos-chave. São Paulo: Contexto, 2005.

CHARTIER, R \& CAVAllo, G. História da leitura no mundo ocidental. São Paulo: Ática, 1999. 
CHARTIER, R. Cultura escrita, literatura e história. Trad. Ernani Rosa. Artmed: Porto Alegre, 2001.

.Écouter les morts avec les yeux. Paris: Collège de France: Fayard, 2009.

. A história ou a leitura do tempo. Trad. Cristina Antunes. Belo Horizonte: Autêntica, 2009.

DEBRAY, R. Cours de médiologie générale. Gallimard: Paris, 1991.

- Curso de midiologia geral. Trad. Guilherme João de Freitas Teixeira. Petrópolis: Vozes, 1993.

. Manifestes mediologiques. Gallimard: Paris, 1994.

. Introduction à la médiologie. PUF: Paris, 2000.

FAPESP. Indicadores de Ciência, Tecnologia e Inovação em São Paulo. FAPESP: São Paulo, 2004. Disponível em http://www.fapesp.br/publicacoes/indct/cap01/cap01.htm. Acessado em março de 2012.

FIORIN, J. L. Interdiscursividade e intertextualidade. In: BRAIT, Beth. Bakhtin: outros conceitos-chave. São Paulo: Contexto, 2006, p. 161-194.

FOLHA DE S. PAULO. Manual da Redação. 6ª ed. São Paulo: Publifolha, 1992.

FOLHA DE S. PAULO. Manual da Redação. $16^{\mathrm{a}}$ ed. São Paulo: Publifolha, 2010.

FLOCH, Jean-Marie. Identités visuelles. Paris: Puf, 1995.

GALLI, F. C. S. Linguagem da Internet: um meio de comunicação global. In: MARCUSCHI, L.; XAVIER, A. Hipertexto e gêneros digitais. Rio de Janeiro: Lucerna, 2004, p. 120-134. 
GARCIA, A. Intertextualidade, hipertextualidade e 'interestualidade'. In: Anais do II CLUERJ-SG, Ano 2, nº 01, 2005.

GENETTE, G. Introduction à l'architexte. Paris: Seuil, 1979. . Palimpsestes: La littérature au second degré. Paris: Seuil, 1982. . Seuils. Paris: Seuil, 1987.

GRILlo, S. V. de C. A noção de campo nas obras de Bourdieu e do Círculo de Bakhtin: suas implicações para a teorização dos gêneros do discurso. In: Revista da ANPOLL. São Paulo: v.19, 2005, p.151 - 184.

\& VELOSO, S. R. de A. Diálogos entre Maingueneau e o Círculo de Bakhtin. In: Filologia e linguística portuguesa. São Paulo, nº 9, 2008, p.229-251.

\& FERRAZ, F. S. M. O enunciado e seus gêneros. In: CARETTA, E., CONDÉ, V., GIL, B. Modelos de análise lingüística. São Paulo: Contexto, 2009, p. 135-152.

. Enunciados verbovisuais na divulgação científica. In: Revista da Anpoll. Belo Horizonte, $n^{\circ} 27,2009$, p. 215-246.

JENNY, Laurent. Intertextualités. Poétique: revue de théorie et d'analyse littéraires, no, 27. Paris: Seuil.

KOCH, I. G. V. O texto e as construções do sentido. São Paulo: Contexto, 2003. . Introdução à Lingüística Textual: trajetória e grandes temas. São Paulo: Martins Fontes, 2004. . Hipertexto e construção do sentido. Alfa, nº 51. São Paulo: 2007, p. 23-38.

; BENTES, A. C. \& CAVALCANTE, M. M. Intertextualidade: diálogos possíveis. São Paulo: Cortez, 2008. 
KOMESU, F. C. Blogs e as práticas de escrita sobre si na Internet. In: MARCUSCHI, L.; XAVIER, A. Hipertexto e gêneros digitais. Rio de Janeiro: Lucernax, 2004, p. 23-38.

KRISTEVA, J. Recherches pour une sémanalyse. Paris: Éditions du Seuil, 1969.

. Le mot, le dialogue et le roman. In: Recherches pour une sémanalyse. Paris: Éditions du Seuil, 1969 [1966], p. 82-112.

. Pour une sémiologie des paragrammes. In: Recherches pour une sémanalyse. Paris: Éditions du Seuil, 1969 [1966], p.113-146.

. Le texte clos. In: Recherches pour une sémanalyse. Paris: Éditions du Seuil, 1969 [1966-1967], p. 52-81.

. L'engendrement de la formule. In: Recherches pour une sémanalyse. Paris: Éditions du Seuil, 1969, p. 52-81.

. Une poetique ruinée. In: BAKHTINE, Mikhaïl. La poetique de Dostoïevski. Trad. Isabelle Kolitcheff. Paris: Éditions du Seuil, 1970.

. O texto do romance. Trad. Manuel Ruas. Lisboa: Livros Horizonte, 1984 [1979].

LÉVY, P. As tecnologias da inteligência: o futuro do pensamento na era da informática. Trad. Carlos Irineu da Costa. Rio de Janeiro: Ed. 34, 1993. . O que é virtual. Trad. Paulo Neves. Rio de Janeiro: 34, 1996. . Cibercultura. Trad. Carlos Irineu da Costa. São Paulo: Ed. 34, 1999.

LOBO, A. C. Hipertextualidade e hipertexto: seria uma redundância? In: Anais Eletrônicos, $\mathrm{n}^{\circ}$ 01, UFPE, 2008. 
. Hipertextualidade: por uma abordagem enunciativa de hipertextos. Dissertação de mestrado. Fortaleza: UFPE, 2009.

LUGRIN, G. Le mélange des genres dans l'hyperestructure. In: ADAM, J.M., HERMAN, T. et . SEMEN. Presses Universitaires de Franche-Comté, nº 13, 2001. Consultado em 07 de fevereiro de 2009. Disponível em <http://semen.revues.org/4381>.

MACEDO, C. C. de \& GRILLO, S. V. de C. Dialogismo e forma composicional em reportagens da revista "Superinteressante". Revista ALFA, v.54, no 1, 2010, p. 59-80.

MACHADO, F. S. Gêneros da divulgação científica na internet. Dissertação de mestrado Faculdade de Filosofia, Letras e Ciências Humanas, Universidade de São Paulo, São Paulo, 2007.

MACHADO, I. A. Língua entre linguagens: a argumentação gráfica na comunicação da ciência. Tese de livre-docência defendida na Universidade de São Paulo. São Paulo, 2011.

MAINGUENEAU, D. Gèneses du discours. Bruxelles: Pierre Mardaga Editeur, 1984. . L'analyse du discours. Paris: Hachette, 1991. . Analyser les textes de communication. Armand Colin: Paris, 2005.

MARCUSCHI, L.; XAVIER, A. Hipertexto e gêneros digitais. Rio de Janeiro: Lucerna, 2004.

, L. A. Gêneros textuais emergentes no contexto da tecnologia digital. In: MARCUSCHI, L.; XAVIER, A. Hipertexto e gêneros digitais. Rio de Janeiro: Lucerna, 2004, p. 13-67.

MCKENZIE, D. F. Making meaning: printers of the mind and other essays. Boston: University of Massachusetts Press, 2002. 
MCLUHAN, M. Os meios de comunicação como extensões do homem. Trad. Décio Pignatari. São Paulo: Cultrix, 2007.

MELO, C. T. V. de. A análise do discurso em contraponto à noção de acessibilidade ilimitada da Internet. In: MARCUSCHI, Luiz Antônio \& XAVIER, Antônio Carlos. Hipertexto e gêneros digitais. Rio de Janeiro: Lucerna, 2004, p.134-143.

MELO NETO, João Cabral de. Rios sem discurso. In: A educação pela pedra. Rio de Janeiro: José Olympio. 1979, p.26.

MOTA, Vinícius. Leitor tem renda e escolaridade altas. Folha Online, 2000. Disponível em: http://www1.folha.uol.com.br/folha/80anos/quem_e_o_leitor.shtml.

Consultado em 12/12/2011.

MOURA, M. Mídia e construção de imagens da Tecnociência brasileira. In: VOGT, Carlos. Cultura Científica: desafios. São Paulo: EDUSP, 2006, p. 132-179.

PAVEAU, M. La norme dialogique. Propositions critiques en philosophie du discours. SEMEN [online], 29/2010. Disponível em : http://semen.revues.org/8793. Consultado em $18 / 06 / 2011$.

PAVEAU, M. \& SARFATI, G-E. Les grandes théories de la linguistique : de la grammaire comparée à la pragmatique. Paris : Armand Colin, 2003.

PECHÊUX, M. Rôle de la mémoire. In: ARCHARD, Pierre et al. (orgs). Linguistique et histoire. Paris: Editions MSH, 1983, p. 261-268.

PIETROFORTE, A. V. Semiótica Visual: os percursos do olhar. São Paulo: Editora Contexto, 2010.

PIETROFORTE, A. V. Análise do texto visual: a construção da imagem. São Paulo: Editora Contexto, 2011. 
PINHEIRO, R. C. Estratégias de leitura para a compreensão de hipertextos. In: ARAÚJO, J. C. \& BIASI-RODRIGUES, B. Interação na internet: ovas formas de usar a linguagem. Rio de Janeiro: Lucena, 2005.

POSSENTI, S. Simulacro e interdiscurso em slogans. In: Os limites do discurso. Curitiba: Criar, 2002.

. Notas um pouco céticas sobre hipertexto e construção de sentido. In: Os limites do discurso. Curitiba: Criar, 2002.

ORLANDI, E. Análise de discurso: princípios e procedimentos. Campinas: Pontes, 2003.

RIFFATERRE, M. Sémiotique de la poésie. Paris: Seuil, 1983.

SANTOS, H. F. D. Gênese e memória do estruturalismo como paradigma de interpretação no discurso das ciências humanas no século XX. Fólio Revista de Letras, n. 1,v.1. Bahia: Edições UESB, 2009.

SILVEIRA, E. R. da \& SILVA, S. C. P. da. As relações de interatividade e hipertextualidade do jornal on line "O Estado de S. Paulo”. Campinas: Intercom Sociedade Brasileira de Estudos Interdisciplinares da Comunicação 2007, p.1-9.

TODOROV, T. Mikhaïl Bakhtine: le principe dialogique. Paris: Éditions du Seuil, 1981.

VELOSO, S. R. A. Polêmicas discursivas na perspectiva bakhtiniana: embates entre vozes de cientistas e outras vozes na arena do Roda Viva. Tese de Doutorado. Faculdade de Filosofia, Letras e Ciências Humanas, Universidade de São Paulo, São Paulo, 2011.

VOGT, C. A espiral da cultura científica. In: ComCiência, jul. 2003. Disponível em: $<$ http://www.comciencia.br/reportagens/cultura/cultura01.shtml $>$. Acesso em: março de 2012. 
VOLOSHINOV, Valentin Le discours dans la vie et le discours dans la poésie. In: TODOROV, Tzvetan. Mikhaï Bakhtine: le principe dialogique suivi de écrits du cercle de bakhtine. Paris: Éditions du Seuil, 1981. p. 181-215.

WADELLI, R. Leituras do hipertexto: viagem ao Dicionário Kazar. Florianópolis: Editora da UFSC, 2003.

XAVIER, A. C. dos S. O hipertexto na sociedade de informação: a constituição do modo de enunciação digital. Tese de doutorado. Campinas: UNICAMP, 2002. 


\section{Sites utilizados para consulta}

Banco de dados da Folha. Disponível em http://bd.folha.uol.com.br/bd_pesquisa.htm.

FolhaPress. Disponível em http://www.folhapress.com.br/.

Folha Online. Disponível em http://www.folha.uol.com.br/. 